- DEPARTMENT OF THE INTERIOR

UNITED STATES GEOLOGICAL SURVEY

GEORGE OTIS SMITH, DIRECTOR

BULLETIN 529

THE

\title{
ENRICHMENT OF SULPHIDE ORES
}

BY

WILLIAM HARVEY EMMONS

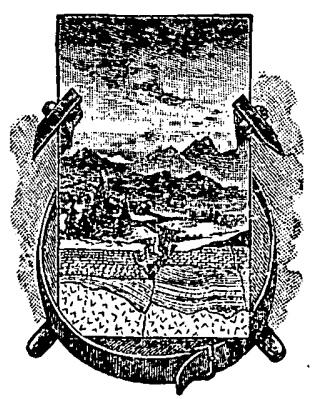

WASHINGTON

GOVERNMENT PRINTING OFFICE

1913 



\section{CONTENTS.}

Introduction

Statement of theory ........................................... 9

Sources of information and acknowledgments..................... 11

Distinctions between primary and secondary deposits................. 12

Physical conditions and enrichment............................... 16

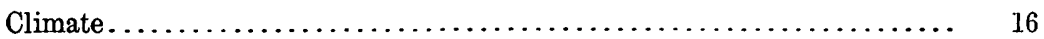

Temperature................................... 16

Rainfall.............................................. 18

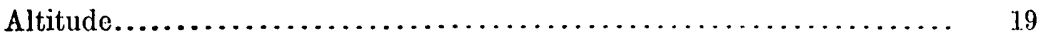

Relief.................................................. 19

Permeability ............................................. 20

Influence of rate of erosion on rate of sulphide enrichment............. 21

Age of the primary deposits and their periods of weathering............ 22

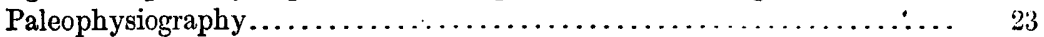

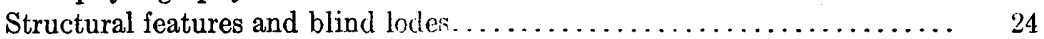

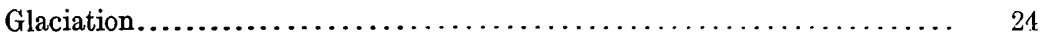

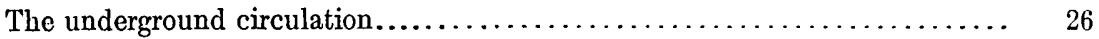

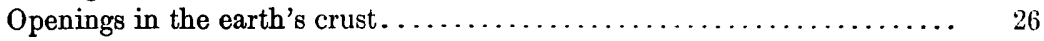

The level of ground water..................................... 27

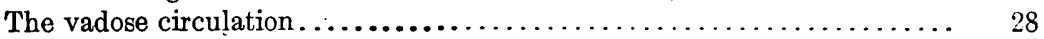

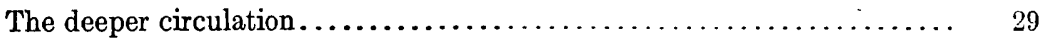

The region of nearly stagnant waters............................ 30

The several successive zones.................................... 31

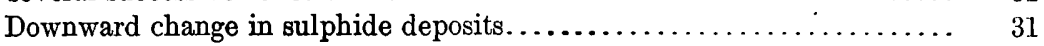

The oxidized zone....................................... 32

Conditions in the oxidized zone........................... 32

Segregation of the metals in the oxidized zone.................. 33

Depth of the oxidized zone............................... 36

Submerged oxidized ores................................ 37

Transitions between oxidized and sulphide ores................ 38

The secondary sulphide zone................................ 39

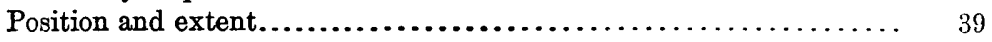

Relation to the water level............................... 41

Precipitation of sulphides above the water level................ 42

Textures of secondary sulphide ore......................... 44

Estimates of vertical extent of portions of lodes eroded.............. 47

Chemistry of sulphide enrichment.............................. 48

Experimental data on the solution and precipitation of the metals....... 48

Composition of mine waters................................. 60

Analyses............................................... 60

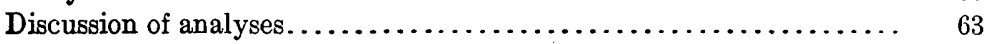

Mines represented................................... 63 
Chemistry of sulphide enrichment-Continued.

Composition of mine waters-Continued.

Discussion of analyses-Continued.

Page.

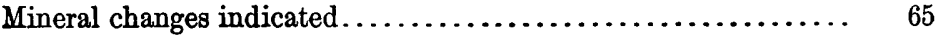

Sulphates and sulphuric acid ................... 65

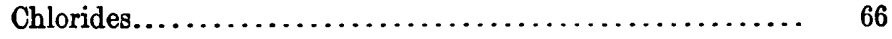

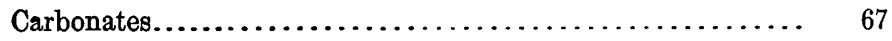

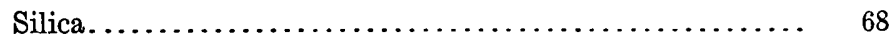

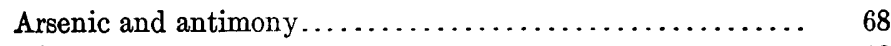

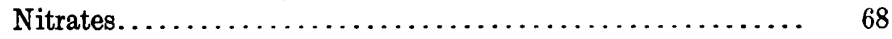

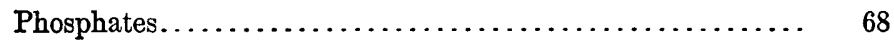

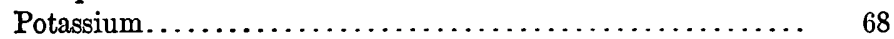

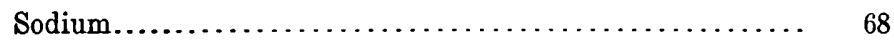

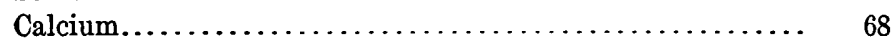

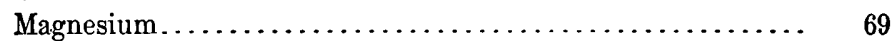

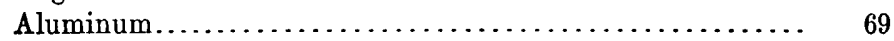

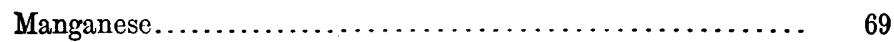

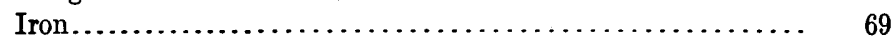

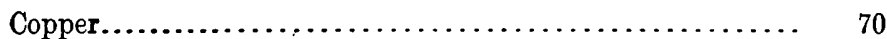

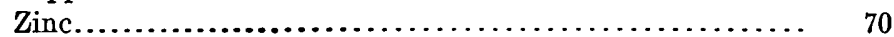

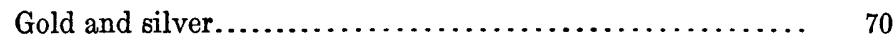

Changes in composition-depending on depth............... 70

Precipitates from mine waters under superficial conditions...... 73

Oxidation and solution of certain metallic sulphides............. 75

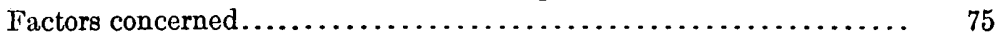

Relative rate of solution of several sulphides in an oxidizing environ-

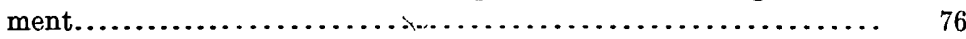

Net results of chemical changes during oxidation of certain ores..... 78

Relative rate of solution of several sulphides in a reducing environment. $\quad 83$

Metasomatic replacement of primary sulphides by secondary sulphides and relations indicated by Schuermann's series..................

Source of the sulphur of secondary sulphides and generation of hydrogen sulphide.

Processes of sulphide enrichment compared with the process of separating the metals in qualitative chemical analysis.................... 88

Decrease in acidity of descending sulphate waters............... 89

Changes in the state of oxidation of descending acid sulphate solutions... $\quad 90$

Rate at which hydrogen sulphide is generated from several primary sulphides by cold dilute acid sulphate waters.

Composition of the primary ore as a factor determining the vertical extent

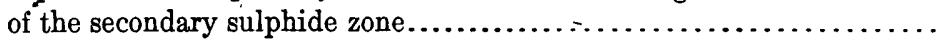

Some chemical relations and minerals of copper. . . . . . . . . . . . . .

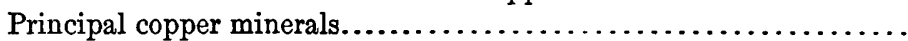

Solubility of some copper compounds.....................

Nature and relations of the copper minerals...................

Occurrence of the copper minerals...................... 93

Some chemical relations and minerals of silver................. 114

Principal silver minerals............................. 114

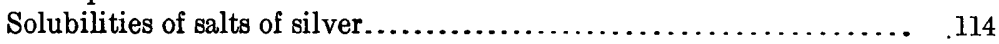

Nature and relations of the silver minerals. . . . . . . . . . . . . . 114

Occurrence of the silver minerals.......................... 118

Some chemical relations and minerals of gold $\ldots \ldots \ldots \ldots \ldots \ldots \ldots \ldots \ldots \ldots \quad 125$

Solubility of gold .................................... 125

Precipitation of gold with manganese oxide................. 128 
Chemistry of sulphide enrichment-Continued.

Some chemical relations and minerals of gold-Continued. Page.

Sources of manganese in gold deposits.......................... 130

Placers and outcrops.................................... 131

Concentration in the oxidized zone......................... 132

Vertical relation of deep-seated enrichment in gold to chalcocitization.. 133

Gold and silver tellurides................................. 135

Some chemical relations and minerals of lead ..................... 135

Principal lead minerals................................... 135

Solubilities of lead compounds.............................. 135

Occurrence of the lead minerals........................... 136

Some chemical relations and minerals of zinc...................... 140

Principal zinc minerals................................... 140

Solubilities of zinc compounds............................. 140

Occurrence of the zinc minerals............................. 141

Some chemical relations and minerals of iron ....................... 143

Principal iron minerals.................................. 143

Solubilities of iron salts................................. 143

Nature and relations of the iron minerals....................... 143

Occurrence of the iron minerals............................ 145

Some gangue minerals...................................... 150

Nature and genesis.................................... 150

Some aluminum minerals................................. 151

Occurrence....................................... 151

Feldspars........................................ 152

Sericite........................................ 152

Kaolin.......................................... 153

Alunite............................................ 154

Gibbsite, bauxite, and diaspore........................ 154

Silica............................................. 155

Sulphur and sulphates................................. 157

Solubility .......................................... 157

Occurrence....................................... 158

Carbonates................................................. 161

Summary review of several classes of deposits........................ 162

Copper deposits with little or no chalcocite ....................... 162

Copper deposits with shallow chalcocite zones.................... 164

Copper deposits with moderately deep chalcocite zones.............. 164

Copper deposits with deeply oxidized zones..................... 165

Gold deposits exhibiting secondary concentration................ 166

Silver and silver-gold deposits............................... 168

Review of mining districts..................................... 170

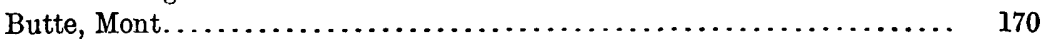

Bingham, Utah................................... 177

Bisbee, Ariz., by F. L. Ransome.......................... 179

Globe and Miami, Ariz., by F. L. Ransome.................... 183

Ray, Ariz., by F. L. Ransome.......................... 186

Morenci, Ariz.......................................... 187

Ely, Nev., by A. C. Spencer.............................. 189

Santa Rita and Hanover districts, N. Mx ...................... 191

Jerome, Ariz., by F. L. Ransome......................... 192

Burro Mountain district, N. Mex............................... 193

Cananea, Mexico........................................... 194 
Review of mining districts-Continued. Page.

Nacozari, Mexico......................................... 196

Silverbell, Ariz.................................... 197

San Francisco region, Utah, by B. S. Butler................... 197

Shasta County, Cal......................................... 199

Yerington, Nev..................................... 200

Vancouver, British Columbia............................... 201

Snowstorm lode, Cœur d'Alene district, Idaho................... 202

Copperopolis, Cal..................................... 202

Boleo, Lower California....................................... 203

Braden Copper mines, Chile................................. 203

Queen of Bronze mine, Oreg............................... 204

Encampment district, Wyo............................... 204

Ducktown, Tenn........................................ 205

Gossan lead, Va........................................... 207

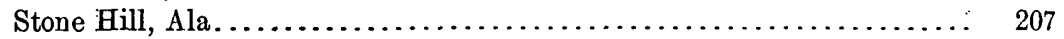

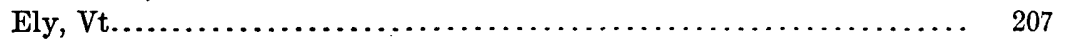

La Dicha, Mexico..................................... 208

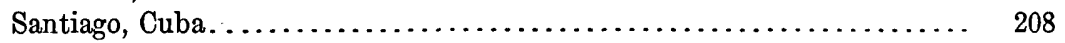

Pinar del Rio, Cuba.................................... 209

Boundary district, British Columbia......................... 209

San Jose, Mexico.................................... 210

La Reforma mine, Campo Morado, Mexico................... 211

Velardeña district, Mexico.................................. 211

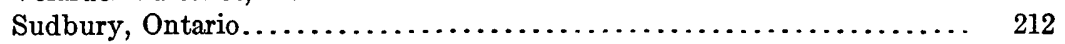

Prince William Sound, Alaska............................. 214

Kasaan Peninsula, Prince of Wales Island, Alaska................. 214

Bonanza mine, Chitina copper belt, Alaska...................... 215

Mother Lode district, Cal.................................. 216

Nevada City and Grass Valley, Cal........................... 216

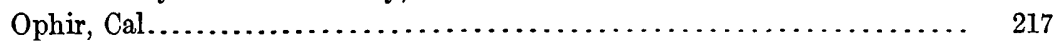

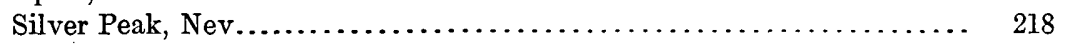

Edgemont, Nev........................................ 218

Douglas Island, Alaska.................................. 218

Berners Bay region, Alaska................................. 219

Black Hills, S. Dak............................... 219

Hedley district, British Columbia............................ 220

Appalachian districts..................................... 221

Annie Laurie mine, Utah. . . . . . . . . . . . . . . . . . . . . . . . 222

Manhattan, Nev.................................... 222

Bullfrog, Nev....................................... 223

Gold Circle, Nev................................... 223

Delamar mine, Nev................................. 223

Exposed Treasure mine, Cal............................... 224

Bodie, Cal. ...................................... 225

Little Burro Mountains, N. Mex.......................... 29

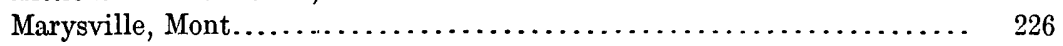

Summit district, Colo................................ 226

Bohemia mining district, Oreg............................ 228

San Juan region, Colo . . . . . . . . . . . . . . . . . . . . . . . . . . . 228

Cripple Creek, Colo................................... 229

Georgetown quadrangle, Colo............................. 232

Goldfield, Nev....................................... 233 
Review of mining districts-Continued. Page.

Philipsburg, Mont..................................... 233

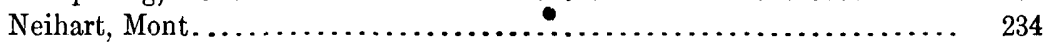

Tintic district, Utah.................................. 235

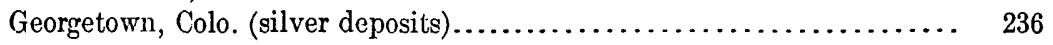

Breckenridge, Colo.................................. 237

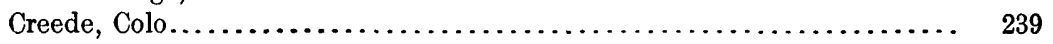

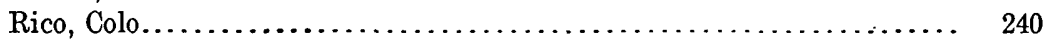

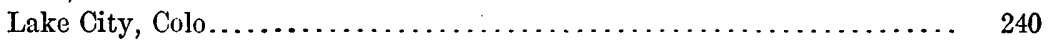

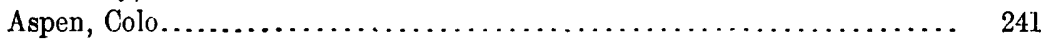

Leadville, Colo.................................... 242

Eureka, Nev........................................... 244

Pioche, Nev......................................... ' 245

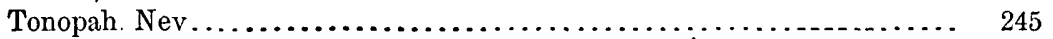

Comstock lode. Nev .................................. 246

St. Eugene mine, Moyie, British Columbia.................... 249

Cobalt, Ontario ..................................... 250

Rossland, British Columbia............................... 251

Coeur d'Alene. Idaho (lead-silver deposits) ................... 252

Index ...................................................... 253 



\title{
THE ENRICHMENT OF SULPHIDE ORES.
}

\author{
By William Harvey Emmons.
}

\section{INTRODUCTION.}

\section{STATEMENT OF THEORY.}

Sulphide ores exposed to weathering at or near the surface of the earth break down and form soluble salts and minerals that are stable under surface conditions. No metallic sulphide that is long exposed to air and water remains unaltered. Iron sulphides, which are present in practically all sulphide ores, are changed by weathering to iron oxides, and the changes are attended by the liberation of sulphuric acid. Many of the motals form soluble sulphates with sulphuric acid, and when conditions favor their migration downward they are carried in solution to depths where air is excluded. Unoxidized rocks are in general alkaline. Acid solutions that encounter such rocks in the regions where air is excluded will lose acidity, and as the solutions approach a neutral or alkaline condition some of the metals they contain are deposited. If the solutions of the metallic sulphates encounter metallic sulphides in depth precipitation may take place, or there may be an interchange between the metals in solution as sulphates and the metallic sulphides. Thus as a result of precipitation or chemical interchange the metals are redeposited and certain portions of the ore bodies become enriched.

The theory of sulphide enrichment, announced in 1900, has been found to have wide application. Many deposits, especially of ores of copper, are leached near the surface and are richer below the leached zones. The ore at still greater depths is of lower grade. According to the theory the copper leached from the upper zone has been carried downward and redeposited, forming an enriched zone, and the deeper, lower-grade sulphide ores are assumed to be like the original or primary mineralization of the whole deposit. Some deposits of gold ores and of silver ores show similar features, but the changes in the character of the ore in such deposits are generally less notable. Relatively few deposits of lead and zinc have clearly defined secondary sulphide zones, although some such deposits show appreciable enrichment. The theory of sulphide enrichment has now become fairly well understood and has proved to be of considerable economic value, for it has been successfully applied in the development of many deposits of the metallic sulphides. 
Similar geologic processes operating under approximately similar conditions produce approximately similar results, and any theory formed to explain the relations that exist in some deposits might reasonably be cited to explain the absence of like relations in other deposits. It has been found, however, that the theory of sulphide enrichment does not apply to all deposits and that many valuable deposits of sulphide ores are primary. It is not applicable even to all deposits of copper-bearing sulphides, in which secondary changes that have taken place are recorded more clearly than in deposits of other metals. Moreover, it is not clear why some deposits show extensive enrichment and others show little or none.

As data are accumulated some of the geologist's most cherished hypotheses may be overthrown. Until recently nothing seemed to rest on a firmer foundation than the belief that the presence of chalcocite is almost certain evidence of enrichment by cold solutions, but recent studies have shown that, without much doubt, this mineral is a primary constituent of certain copper ores that have been deposited by ascending thermal waters.

The recent development at Bisbee, Ariz. (p. 182), of extensive and deep oxidized ores related to a pre-Comanche erosion surface which is not parallel to but is inclined to the present underground water level; the development at Miami, Ariz. (p. 185), of an extensive chalcocite zone not definitely related to but apparently older than the present topography; and the exceptional features of the secondary deposits in several other districts clearly indicate that the theory of sulphide enrichment can not be applied perfunctorily to any deposit. The deductions that may be drawn from it are generally of so great commercial importance that its use is fraught with danger unless it is used with an adequate understanding of the general geology of the region containing the deposits to which it is applied.

The chemistry of sulphide enrichment offers an especially attractive field for experimental study because the natural conditions of temterature, pressure, and concentration can be closely duplicated in the laboratory, but at present the results of chemical experiments in ore enrichment leave much to be desired. It should be acknowledged at the outset that some of the data concerning sulphide enrichment appear to be conflicting and that many of the problems are now only in process of solution.

This paper is offered not as a contribution of many original data, but rather as a summary of a part of the existing knowledge of the subject. I hope it may suggest to those who are engaged in geologic work and in mining some lines of approach to the problems to be solved. The solution of these problems must depend very largely on the observations of the engineer or geologist who can watch the 
changes in the successively excavated parts of an ore body. He has a distinct advantage over the official geologist, who visits it only at one stage of its development, perhaps after the most illuminating exposures have been destroyed. To the chemist this paper is an appeal for more experimental data on the important mineral syntheses involved in the processes. I realize fully that there may be serious omissions and possibly serious errors in the discussion of the complex and scattered data here presented, and I shall esteem it a favor if anyone whose statements I may have misquoted or misinterpreted will set me right, and if those who have had superior opportunities for study of certain districts will correct any wrong impressions that I may have given.

\section{SOURCES OF INFORMATION AND ACKNOWLEDGMENTS.}

Among the papers that treat the subject of sulphide enrichment are those of S. F. Emmons, ${ }^{1}$ W. H. Weed, ${ }^{2}$ and C. R. Van Hise. ${ }^{3}$ These papers were issued in 1900 , almost contemporaneously, and in them the writers, working independently, assembled the geologic and chemical data bearing on the problem, formulating a clearly stated theory from scattered and undigested observations. Five years later Kemp ${ }^{4}$ wrote a summary of the processes of secondary enrichment of ore deposits of copper, and in 1910 Ransome ${ }^{5}$ issued a comprehensive review of the criteria of downward sulphide enrichment, in which he treats concisely the various processes of enrichment and their results. The nearly related processes of oxidation of ore deposits were discussed by Penrose in $1894 . .^{\circ}$

During the 12 years that have passed since the first papers on sulphide enrichment were issued a number of detailed reports have appeared, treating the geology and ore deposits of certain mining districts. In several of these papers the chemical processes involved are discussed in the light of the field relations of the deposits. The contributions of Lindgren, Ransome, Spencer, Boutwell, Irving, Graton, Spurr, Garrey, Ball, Butler, Lawson, and Gordon are particularly valuable. Since 1905, when the work of collecting the mineral statistics of the United States was placed in the hands of field geologists, the annual reviews of resources, production, and development that have appeared in the reports entitled "Mineral

1 Emmons, S. F., The secondary enrichment of ore deposits: Trans. Am. Inst. Min. Eng., vol. 30, 1901, pp. 177-217.

2 Weed, W. H., The enrichment of gold and silver veins: Trans. Am. Inst. Min. Eng., vol. 30, 1901, pp. 424-448.

8 Van Hise, C. R., Some principles controlling the deposition of ores: Trans. Am. Inst. Min. Eng., vol. 30, 1901, pp. 27-177.

4 Kemp, J. F., Secondary enrichment in ore deposits of copper: Econ. Geology, vol. 1, 1906, pp. 11-25.

- Ransome, F. L., Criteria of downward sulphide enrichment: Econ. Geology, vol. 5, 1910, p. 205.

- Penrose, R. A. F., jr., The superficial alteration of ore deposits: Jour. Geology, vol. 2, 1894, p. 288. 
resources of the United States" have been a never-failing source of information. The chapters on gold, by Waldemar Lindgren and $\mathrm{H}$. D. McCaskey; those on copper, by L. C. Graton and B. S. Butler; those on lead and zinc, by C. E. Siebenthal; and those on the rarer metals, by F. L. Hess, have furnished many valuable data.

Data on the chemistry of the processes of sulphide enrichment have been accumulated rapidly since 1900 . The paper by Schuermann ${ }^{1}$ published in 1888 was for many years the most important source of information respecting the behavior of sulphides in certain reactions involving double decomposition. In $1907 \mathrm{Weigel}^{2}$ published a paper showing the solubilities in water of the metallic sulphides, which, as was pointed out by R. C. Wells, ${ }^{3}$ correspond closely in order to the series found by Schuermann. In $1903 \mathrm{H}$. V. Winchell ${ }^{4}$ published the results of experiments in chalcocitization of sulphide ores. More recently experiments in the solution or precipitation of the metals have been made by Sullivan, Wells, Allen, Stokes, Buehler and Gottschalk, Brokaw, Cooke, Grout, A. N. Winchell, and many others.

I wish to acknowledge my indebtedness to my colleagues of the United States Geological Survey, especially to Messrs. Waldemar Lindgren, F. L. Ransome, A. C. Spencer, and B. S. Butler, who have read portions of this paper and have generously contributed unpublished data on certain districts. Mr. R.C. Wells, of the United States Geological Survey, and Dr. W. H. Hunter, of the University of Minnesota, have read critically certain parts of this paper, where the problems of physical chemistry are treated, and many of the reactions have been discussed with Dr. E. T. Allen and associates, of the Carnegie geophysical laboratory at Washington, and with Mr. F. W. Clarke of the United States Geological Survey.

\section{DISTINCTIONS BETWEEN PRIMARY AND SECONDARY DEPOSITS.}

In this paper I apply the term primary to all bodies of ores whose chemical and mineral composition have remained essentially. unchanged by superficial agencies since the ores were deposited. These include sulphide ores that have replaced the wall rock and are "secondary" after rock-making minerals or sedimentary beds. A secondary ore, as the term is here used, is one that has been altered by superficial agencies. The term is not restricted to pseudomorphous replacements but is used to include also material deposited by super-

\footnotetext{
I Schuermann, Ernst, Ueber die Verwandtschaft der Schwermetalle zum Schwefel: Liebig's Ann. der Chemie, vol. 249, 1888, p. 326.

2 Weigel, Oskar, Die Löslichkeit von Schwermetallsulfiden in reinem Wasser: Zeitschr. phys. Chemie, vol. 58,1907 , pp. 293-300.

${ }^{8}$ Wells, R. C., The fractional precipitation of sulphides: Econ. Geology, vol. 5, 1910, pp. 1-14.

1 Winchell, H. V., Synthesis of chalcocite and its genesis at Butte, Mont.: Bull. Geol. Soc. America, vol. - 14, 1903, pp. 269-276.
} 
ficial processes in fractures in and near the primary ore bodies. It is unfortunate that the term "secondary" is used with different meanings and that the distinction between primary and secondary ores can not everywhere be sharply drawn, but the diverse usage of the terms has become firmly fixed in the literature, and ambiguity can generally be avoided only by using qualifying phrases.

A discussion of the genesis of primary ore deposits does not come within the scope of this review, but in order to distinguish clearly between primary and secondary ores as the terms are here used, it is desirable to mention briefly the several classes of primary deposits. Any attempt to classify ore deposits by means of the data now available is hazardous. Sharp divisions are not generally found in nature, and any classification based on genesis should be regarded merely as a convenient means of comparison and study. Not only do some classes of primary ores overlap one another, but primary ores formed at moderate depths by cold solutions and those formed very near the surface by ascending thermal waters are in many respects similar to deposits formed by descending sulphate solutions in processes of secondary alteration, and it is not everywhere practicable to draw sharp distinctions between them. The following classification includes the more important groups of primary ores:

Syngenetic deposits; contemporaneous with the inclosing rocks:

Sedimentary beds; mechanical, chemical, organic, etc.

Magmatic segregations; consolidated from molten magmas.

Epigenetic deposits; . deposited later than the inclosing rocks:

Pegmatite veins; deposited by "aqueo-igneous" magmatic solutions.

Contact-metamorphic deposits; deposited in intruded rocks by fluids passing from consolidating intruding rocks.

Deposits of the deep vein zone; formed at high temperature and under great pressure, generally in and along fissures.

Deposits formed at moderate and shallow depths by ascending hot solutions.

Deposits formed at and near the surface by ascending hot solutions.

Deposits formed at moderate and shallow depths by cold meteoric solutions.

The deposits of any of these groups may be changed by various geologic processes. They may be buried deeply and altered by dynamic metamorphism, or, if exposed to surface agencies, they may be leached or enriched by superficial processes.

Sedimentary beds are the sources of a great many economic products-such as coal, clay, oil, iron ore, or manganese. Of the sulphide ores, however, very few are sedimentary. Some of the copper deposits in the "Red Beds" have been considered sedimentary. The best known example is the "Kupferschiefer" of Mansfield, Germany. Workable sulphide deposits of sedimentary origin in the United States are unknown to me.

Magmatic segregations are products of the differentiation of igneous magmas. Genetically considered they are in the strict sense igneous 
rocks. These deposits include ore bodies of considerable economic importance, among them some of the magnetic iron ores of the Adirondack Mountains, in New York. No large sulphide deposits of this kind are known in the United States. The nickel-copper deposits of Sudbury, Ontario, are the best-known examples of this group in North America. These deposits have been planed off by glacial erosion in recent geologic time and do not show any considerable enrichment by superficial processes.

Pegmatite veins are very nearly related to magmatic segregations. They are magmatic segregations or end products of crystallization that have been thrust, like igneous dikes, into openings in rocks already consolidated. As they are probably formed from eutectic solutions, many pegmatite veins tend to approach a fairly uniform composition and are also generally characterized by large crystals of rock-making minerals. Pegmatites that have not moved from the parent magma and are not related to openings in rocks could properly be classed with syngenetic deposits, as magmatic segregations, but some authorities reserve the latter term for the more basic differentiation products. In pegmatites the sulphides are present, as a rule, in small quantities, and except some deposits of rare elements they have very little economic importance as sources of the metals.

Contact-metamorphic deposits are formed in intruded rocks by fluids given off by intruding igneous magmas. Many of the ores of such deposits contain the sulphides of copper, zinc, and lead, intergrown with heavy silicates and calcite. In general the ore bodies of this class are not clearly related to determinable fissures. Many of these deposits have been enriched by superficial alteration. As a rule the changes are easily followed in the field, for many minerals that are formed by contact-metamorphic processes are not formed by processes of superficial alteration, and vice versa. In general sulphide enrichment does not extend to great depths in contact-metamorphic ores; the tough, fibrous, or platy minerals of the gangue do not favor extensive fracturing, and the presence of calcite favors precipitation of secondary carbonates near the surface. Noteworthy exceptions to this rule are known.

The deposits of the deep vein zone are mineralogically related, more or less closely, to contact-metamorphic deposits. They have formed in and along openings in rocks, however, and in the main they approach the tabular form more closely than do the contact-metamorphic deposits. As pointed out by Lindgren, who first defined the group, the deposits of the deeper zone have formed under conditions of high temperature and pressure, which prevail also in contact metamorphism. Because high temperature and pressure are necessary for their genesis these deposits do not form at moderate or shallow depths, at least not in fissures that extend to the surface, and there- 
fore they are seldom found in the more recent rocks. The deposits of this group are closely affiliated with the contact-metamorphic deposits on the one hand and with deposits formed at moderate depth on the other and can not be sharply divided from the latter. If this class is made to include only deposits that are related to openings in rocks and that carry in the gangue some of the contact-metamorphic minerals (such as heavy silicates, magnetite, or specularite), it may be said that the examples found in the United States are but little affected by sulphide enrichment. The gold deposits of this group are generally not manganiferous, and silver is not an important constituent of most of them. On the other hand, some important sulphide deposits of copper that carry pyrrhotite and magnetite might be included in this group, and sulphide enrichment has played an important part in the genesis of a number of these pyrrhotitic copper deposits.

The deposits formed at moderate and shallow depths by ascending thermal solutions constitute a very important group, which includes numerous deposits of ores of copper, gold, silver, lead, and zinc. Many of these deposits show important sulphide enrichment and illustrate the downward migration of the metals. Some of them are noted for relatively small bodies of very rich ore, locally developed in a larger lower-grade deposit. This group, more than any other, may be characterized as the "bonanza" group. Some of the bonanzas are due to sulphide enrichment, but doubtless many of them are primary.

Much may be said for the theory that some of the metals are precipitated most effectively from ascending thermal alkaline solutions in the zone where they first encounter descending ground water. Whether the solutions are alkali chlorides, alkali sulphides, or alkali carbonates, a decrease in temperature and partial oxidation would cause precipitation. An alkali sulphide solution containing iron would be converted to a ferrous sulphate solution, and from such a solution gold would be deposited almost completely. Some of the metals may be precipitated from alkali sulphide solutions merely by dilution. In the deposits of this group, more than in any other, the presence of bonanza ore has little genetic significance. Each deposit and each ore shoot is a separate problem. Even its relation to the present surface is not everywhere conclusive, for obviously the primary bonanzas may have a genetic relation to a former zone of ground water-a zone which is itself superficial but which may not be determinable.

Deposits of sulphide ores formed at or very near the surface by asscending hot solutions are mainly of scientific rather than economic importance, although a few of them have been exploited for the metals. As atmospheric oxygen is present in the superficial zone the minerals they contain include the hydrous oxides and various sulphates, and as the pressure is nearly atmospheric the temperature 
can not be much above $100^{\circ} \mathrm{C}$. Consequently the minerals form under physical conditions that are not greatly different from those found in the zones of surface alteration and sulphide enrichment where ores are exposed to the action of surface agencies.

The deposits formed at moderate and shallow depths by cold solutions include a large number of important deposits of lead and zinc in the Mississippi Valley and many copper deposits in Colorado, New Mexico, and Utah. Examples could be multiplied, but these define the type. The conditions under which these deposits form are doubtless closely similar to those which exist in zones of sulphide enrichment, and many of the minerals formed are found also in the secondary sulphide zones. Much evidence has been cited to show that these deposits were formed by ground water that gathered its metallic contents from great masses of rocks in which the metals were sparingly disseminated. The metallic salts, chiefly sulphates and chlorides, were gathered in water channels, and the metals were deposited as sulphides where conditions were favorable. In many examples some form of organic material supplied the precipitating agent. If deposition had taken place on an older sulphide these deposits would be classed as secondary sulphide ores, but in general there is no evidence that bodies of older sulphide ore occupied the place of the deposits. These ores are therefore considered primary, although they have been leached by ground water from an older metalliferous rock.

\section{PHYSICAL CONDITIONS AND ENRICHMENT.}

The processes of sulphide enrichment depend on the physical conditions, the environment, and the geologic history of the deposits and on their chemical and mineral composition. Of the purely physical conditions, the climate, altitude, and relief are important. Permeability of the deposits is an essential condition, for if solutions can not find access to the lower horizons the metals dissolved near the surface may be scattered. The duration of the period of weathering is important also, for under similar conditions the amount of solution is directly proportional to the time during which the deposits are exposed to weathering. Briefly, there is scarcely a feature of the geologic history of a deposit that may not affect the extent and character of its enrichment.

\section{crimate.}

TEMPERATURE.

A warm climate, in so far as it favors chemical action, is favorable to sulphide enrichment. Deposits in high latitudes are not so likely to show extensive migration of the metals, because low temperature decreases chemical activity, and freezing prevents solution. Where the ground is frozen to considerable depths during the winter 
and thaws out only a short distance below the surface during the summer, thorough weathering can not extend to great depths. Assuming the persistence of the present relation between latitude and climate, it may be said that bonanzas of secondary ore are probably less numerous and less extensive in higher than in lower latitudes. ${ }^{1}$

In late geologic time large areas in northern latitude have been 'glaciated, and in many places the surface has been planed off by ice erosion. The altered zones of many deposits have doubtless been removed. Thus the deposits of the North differ from those of lower latitudes in two essential respects-in environment and in geologic history. To what extent the smaller development of secondary sulphide ores in the North depends on present temperature and other climatic conditions, and to what extent it is due to recent glacial action, are questions that probably will not be answered until more data are available concerning deposits in driftless areas in high latitudes. In Alaska, Canada, and New England there are but few sulphide deposits of proved secondary origin that are comparable in extent or value to those which have formed at lower latitudes. The available evidence indicates that the large and important ore bodies of these countries are mainly of primary origin. The gold deposits of Douglas Island, Alaska, the copper deposits of Kasaan Peninsula, Latouche Island, and Prince William Sound, and the nickel and copper deposits of the Sudbury region are not deeply oxidized. Carbonate ores extend to a depth of 300 feet in the Copper Mountain mines, Prince of Wales Island, and chalcocite and native copper lie at least 200 feet deep at the Goodro mine. ${ }^{2}$ In many of the deposits in the North, however, the ore has proved to be of approximately uniform grade to considerable depths.

On the other hand, it is well known that great climatic changes have taken place in many regions, and that temperatures have been by no means constant throughout geologic time. Therefore, because the processes of weathering of ore bodies are slow to-day in certain places, it does not follow that they have always been inactive there, and under some conditions secondary deposits formed in older geologic periods in places protected from erosion should be preserved to-day.

The famous Bonanza mine of the Chitina copper belt, Alaska, described by Moffit and Maddren, ${ }^{3}$ presents some unusual features,

1 Winchell, H. V., Prospecting in the North: Min. Mag., vol. 3, 1910, pp. 436-438. Brock, R. W., Discussion of H. V. Winchell's article “Prospecting in the North:” Min. Mag., vol. 4, 1911, pp. 204-205.

2 Wright, F. E. and C. W., The Ketchikan and Wrangell mining districts, Alaska: Bull. U. S. Geol. Survey No. 347, 1908. Wright C. W., Discussion of H. V. Winchell's article "Prospecting in the North:" Min. Mag., vol. 4, 1911, p. 359.

Moffit, F. H., and Maddren, A. G., Mineral resources of the Kotsina-Chitina region, Alaska: Bull. U. S. Geol. Survev No. 374,1909 , pp. $80-86$.

$72293^{\circ}-$ Bull. $529-13-2$ 
which should be mentioned here. The principal deposit is a great mass of chalcocite and bornite, the ore carrying considerable silver and occupying a fractured zone in limestone. There is no evidence that the ore has replaced older sulphides. Although Moffit and Maddren do not state definite conclusions as to the origin of the ore, their discussion clearly implies a genesis independent of magmatic waters: No other conclusion seems to be warranted by the facts available. Geologic and physiographic studies appear to indicate that the Bonanza ore deposit was formed at considerable depth by meteoric waters, which implies that at some period processes of solution and precipitation have operated vigorously in this high latitude.

The rich native silver ores of Cobalt; Ontario, have been considered secondary by some geologists, but all who have studied these deposits are not agreed as to their genesis. ${ }^{1}$ Doubtless some enrichment has taken place in the Copper Cliff and Vermilion mines of the Sudbury region, Ontario. In the Vermilion mine, according to -Barlow, native copper, probably derived by alteration from chalcopyrite, is found 900 feet below the surface. ${ }^{2}$ In general, the secondary sulphide zones of deposits in western Canada in about the same latitude as these are not extensive, but some depositsfor example, the St. Eugene mine, in British Columbia-show unmistakable evidence of sulphide enrichment. The developments in southwestern Canada are not sufficient to permit conclusive statements. There is doubtless a relation between latitude and sulphide enrichment, but it is one which can not be expressed as an invariable rule.

On the other hand, many sulphide deposits in lower latitudes do not show sulphide enrichment. Examples are mines lying in the foothill copper belt, California (see p. 202); La Reforma mine, Mexico (p. 211); the Copper Queen mine, Velardeña, Mexico (p. 211); and several deposits of the Braden Copper Co., Chile (p. 203). According to J. M. Moubray, ${ }^{3}$ several deposits in the Kafue copper district, in northern Rhodesia, between $13^{\circ}$ and $14^{\circ}$ south of the Equator, show copper sulphides at the very surface. In the Sable Antelope mine of this region superficial alteration is practically absent.

RAINFALL.

Since water is the agent of ore enrichment, abundant rainfall is favorable to the formation of secondary ores. The activity of ground water depends principally, however, on the natural acids and other compounds which it dissolves, and the waters in regions of oxida-

\footnotetext{
t Miller, W. G., Notes on the cobalt area: Eng. and Min. Jour., vol. 92, 1911, pp. 645-649. Emmons, S. F., Types of ore deposits, San Francisco, 1911, p. 140.

${ }^{2}$ Barlow, A. E., The nickel and copper deposits of Sudbury, Ontario: Ann. Rept. Geol. Survey Canada vol. 14, pt. H, 1904, p. 106.

'Moubray, J. M., Discussion of H. V. Winchell's article, "Prospecting in the North:" Min. Mag., vol. 4, 1911, pp. 117-118.
} 
tion and solution are generally not saturated with acids. Thus, even in arid regions a moderate supply of ground water under conditions favorable to permeability may bring about appreciable results in relatively brief geologic periods. Some of the silver-gold deposits of the Great Basin clearly show sulphide enrichment, although the primary ores were deposited as late as or later than the Miocene epoch. Ores that form some of the best examples of sulphide enrichment seen in the United States are found in early Tertiary deposits that occur in the arid Southwest, where the annual rainfall is not more than 10 or 12 inches. In some of these deposits, however, much of the secondary ore was probably formed when the rainfall was greater. Concerning this point it is obviously difficult to draw any general conclusions, because data regarding the former climates of many arid regions are inadequate.

In arid countries the ground-water level is likely to lie deep, and the zone of solution is generally not clearly differentiated from the zone of precipitation. Above the water level in ore deposits in arid regions there may be considerable amounts of primary sulphide ore, of secondary sulphide ore, and of oxidized ore; all at approximately the same horizon. In such deposits the secondary sulphide ores, though occurring through greater vertical ranges, may not be concentrated in small volume.

\section{ALTITUDE.}

As a rule, the relief is great in areas of high altitudes, and erosion is consequently more rapid. Moreover, in such areas temperatures are lower and conditions are less favorable to solution. Deposits located at very high altitudes, where rocks are disintegrated by frost and carried away unweathered as talus and bowlders, are not so likely to be extensively enriched as are deposits that lie at lower altitudes. On the other hand, the processes of enrichment are effective under some conditions at considerable altitudes. Many deposits in Colorado that outcrop at altitudes over 10,000 feet above sea level and some in Montana that outcrop at about 8,000 feet above sea level contain extensive zones of secondary ores.

\section{REIIEF.}

In so far as strong relief supplies head, it is favorable to deep and rapid circulation of underground water, and it is likewise favorable to relatively deep enrichment. In base-leveled regions underground circulation is sluggish and the nearly stagnant waters can not descend far into the zone of primary sulphides witheut losing the valuable metals which they dissolve higher up. Calculations made for lodes in the base-leveled region that includes Ducktown, Tenn., show that all or nearly all of the secondary copper in the chalcocite zones may 
be accounted for as a result of the leaching of the gossan below the old base-leveled surface. Under the conditions which prevailed in that district at least, it appears that a large part of the copper dissolved and reprecipitated in any secondary sulphide zone that was formed while the country was being reduced to base-level had been probably redissolved and scattered when the country was baseleveled. In deposits that were more permeable and in those that had been enriched to greater depths the conditions would have been more favorable to the preservation of the secondary ores formed before base-level had been approached. The available data regarding enrichment of base-leveled deposits are scant, for nearly all ore deposits that clearly show sulphide enrichment are in areas of moderate or strong relief.

\section{PERME ABILITY.}

Permeability is essential for sulphide enrichment. If the primary deposits are not permeable the solutions that pass downward through the oxidized zones will move laterally along the contact between oxidized and sulphide ores and ultimately will escape into fractures in the wall rock or reissue as springs at some level below the points of entry. If they do not encounter a reducing environment the metals may be scattered. In rocks that have been shattered by strong movements since the primary ore was deposited there is generally more extensive and deeper enrichment than in deposits that have been but slightly fractured. Brittle minerals like quartz and chert fracture readily, and deposits composed largely of the brittle minerals are generally more deeply enriched than deposits of tough or elastic minerals. Many of the heavy silicate-sulphide ores of contactmetamorphic origin that carry a gangue of abundant fibrous amphibole, mica, chlorite, or like minerals do not show sulphide enrichment to great depths.

In a great many districts, especially in the western part of the United States, pronounced earth movements have occurred since the ores were formed. Many deposits fill fissures or were formed in zones of fracturing that are planes of weakness along which movements took place before ore deposition. To relieve subsequent stresses the same zones of fracture may be again fractured, like a rod that breaks where welded. Such later fracturing has taken place in many mineral deposits after the primary ore was deposited and consequently many of the planes of later movement may parallel the veins, following one wall or the other or cutting irregularly across the ore. If the deposit is composed of material that is easily fractured, such as quartz or chert, the ore may become brecciated and may therefore contain many small openings. A large number of small openings, such as may result from fracturing or shattering of 
the primary sulphides, are more favorable to concentrated enrichment than a few larger openings, for a larger surface of primary ore is exposed to solution along many small openings than along a few large openings. Moreover, inasmuch as friction is greater along small openings, the descent of solutions in them is retarded and therefore reactions that result in precipitation of secondary sulphides may be brought nearly to completion at relatively shallow depths. Very small openings, such as the pore spaces of minerals and other capillary or subcapillary openings, are not effective water channels because friction along them retards circulation. Under some conditions, however, mineral-bearing solutions do penetrate these minute openings and deposit ore in them. In certain deposits near Globe, Ariz., according to Ransome, ${ }^{1}$ specks of secondary chalcocite ore are embedded in solid veinlets of quartz and in silicified schist, indicating a migration of copper, for short distances at least, through exceedingly minute openings. Although water may penetrate such minute openings, it does not circulate freely in them but is nearly stagnant. It would be supposed that the metals would not be carried far in such openings before precipitation, at least not in rocks that are readily attacked by the solutions, but if the openings are lined with siliceous alkali-free minerals or with other minerals that are but slowly affected by the solutions, the reactions which reduce and tend to neutralize the solutions and to precipitate the metals would take place more slowly and the metals might be carried in solution to greater depths.

\section{INFLUENCE OF RATE OF EROSION ON RATE OF SULPHIDE ENRICHMIENT.}

In so far as strong relief is favorable to rapid erosion it is unfavorable to thorough leaching. Where erosion is slow the outcrops and upper portions of deposits are exposed to processes of weathering for periods long enough to favor thorough leaching and, if the metals are reprecipitated at lower depths, to favor ore enrichment. On the other hand, erosion may be delayed to a point beyond which it is unfavorable to solution and precipitation. The downward migration of the zone of oxidation exposes new surfaces to solution, making masses of fresh sulphides available for reconcentration. Consequently where metals dissolve readily, comparatively rapid erosion may favor rapid concentration. The metallic contents of many deposits of secondary ores represent not only what has been leached from the gossan now exposed but also what has been dissolved from portions of the deposits that have been carried away by erosion.

1 Ransome, F. Ln, Criteria of downward sulphide enrichment: Econ. Geology, vol. 5, 1910, pp. 217-218. 


\section{AGE OF THE PRIMARY DEPOSITS AND THEIR PERIODS OF WEATHERING.}

Other conditions being similar, the amount of enrichment must depend on the length of time the deposits have been exposed to weathering and erosion. In general, weathering has acted for a shorter time on late Tertiary deposits than on middle Tertiary, early Tertiary, or Cretaceous deposits. The age of the deposit is not, however, invariably the most important factor in determining the extent of its enrichment, for some of the middle or late Tertiary deposits, such as those in the southwestern part of the United States, show more extensive migration of the metals than is shown by some older deposits which have been exposed to weathering for a much longer time.

In the United States the bonanza deposits of the precious metals are in the main the younger ones, for in general the Paleozoic and older deposits are less rich, though many of them are more nearly uniform in value. Many of the middle or late Tertiary deposits of the precious metals in the Great Basin region-such as those of Tonopah, ${ }^{1}$ the Comstock lode, ${ }^{2}$ and Tuscarora, Nev.- -show unmistakable evidence of enrichment, yet there are good reasons for supposing that the primary ores of many of these young deposits were originally somewhat richer nearer the surface than at greater depths. The deposits of Cripple Creek, Colo., ${ }^{3}$ and of Goldfield, Nev., ${ }^{4}$ show a similar relation as to values and depth, yet sulphide enrichment has probably not been appreciably important in either of these districts. Gold is generally slow of solution, especially where the environment is not favorable to solution. As pointed out by Graton, ${ }^{5}$ some of the gold deposits of the Appalachian region are workable at their outcrops, where gold has remained undissolved ever since the peneplanation of the region, which probably took place as early as Tertiary time.

In general, the sulphide deposits that show the most clearly defined secondary zones are those of copper. The periods of primary deposition of all the known important copper deposits of determined age in the United States, except those of Tintic, Utah, probably antedate the Miocene, and all have long been exposed to erosion and weathering.

1 Spurr, J. E., Geology of the Tonopah mining district, Nevada: Prof. Paper U. S. Geol. Survey No. 42, 1905, p. 95.

2 Becker, G. F., Geology of the Comstock lode and the Washoe district: Mon. U. S. Geol. Survey, vol. 3, 1882, p. 273.

${ }^{3}$ Lindgren, Waldemar, and Ransome, F. L., Geology and gold deposits of the Cripple Creek district, Colorado: Prof. Paper U. S. Geol. Survey No. 54, 1906, p. 204 and Chapter XI.

- Ransome, F. L.,Geology and ore deposits of Goldfield, Nev.: Prof. Paper U. S. Geol. Survey No. 66, 1909, pp. 191-195.

- Graton, L. C., Reconnaissance of some gold and tin deposits of the southern Appalachians, with notes on the Dahlonega mines by Waldemax Lindgren: Bull. U. S. Geol. Survey No. 293, 1906, p. 67. 
According to Ransome, ${ }^{1}$ the deposits at Bisbee, Ariz., may have been exposed to processes of alteration as far back as the Cretaceous. The copper deposits of Velardeña, Mexico, according to Spurr and Garrey, ${ }^{2}$ are probably later than middle Tertiary. The deposits of the Braden mine of Chile, as shown by Pope Yeatman, ${ }^{3}$ are likewise of comparatively late age. In neither of these districts where Tertiary ores are developed are the secondary sulphide zones conspicuously shown. Many copper deposits of the eastern United States are much older, the more important ones having been formed in Paleozoic or earlier periods. Although some of these deposits have long been exposed to erosion, their secondary sulphide zones, though rich and well defined, are not nearly so deep nor so extensive as some in the younger deposits of the West.

I have found no record of secondary sulphide zones that were unquestionably formed in pre-Mesozoic time, although zones of oxide enrichment as old as the Archean are known. According to Van Hise and Leith ${ }^{4}$ some of the rich specular hematites of the Vermilion range are the metamorphosed products of surface enrichment that were indurated and infolded before the beginning of Algonkian time.

\section{PALEOPHYYSIOGRAPHY.}

Inasmuch as sulphide enrichment depends on the action of surtace agencies, it is important to know as far as possible the details of the history of any deposit considered, the length of time it has been exposed to weathering, and whether faulting or folding or a second episode of primary ore formation has taken place since it was first formed. In short, any geologic or physiographic data might have a bearing on the problem of enrichment.

If the present topography is like that which prevailed when primary deposition took place-and this may be the case if the deposits were formed in comparatively late geologic time-then the richer ore of the primary deposits may have an obvious relation to the present surface. In some deposits of gold and silver ore the maximum precipitation of the metals appears to have taken place at relatively short distances below the surface that existed at the time of deposition. Thus the primary ore may show a comparatively constant change in value, which may decrease with increasing depth. In general, the more remote the period of primary deposition the less the probability that the important features of the present topography are similar to those which existed when the primary ores were deposited and the less

\footnotetext{
1 Ransome, F. L., The geology and ore deposits of the Bisbee quadrangle, Arizona: Prof. Pgper U. S, Geol. Survey No. 21, 1904, p. 160. Also this bulletin, p. 179.

2 Spurr, J. E., and Garrey, G. H., Ore deposits of the Velardeña district, Mexico: Econ. Geology, vol. 3, 1908, pp. 724-725.

3 Yeatman, Pope, The Braden copper mines: Min. and Sci. Press, vol. 103, 1911, pp. 769-772.

- Van Hise, C. R., and Leith, C. K., The geology of the Lake Superior region: Mon. U. S. Geol. Survey, rol. 52, 1911, p. 142.
} 
the probability of error in attributing the deposition of a rich primary zone to secondary processes.

\section{STRUCTURAL FEATURES AND BIIND IODES.}

Lodes that do not outcrop are termed "blind" lodes. Some of them do not outcrop because the primary ores did not extend to the present surface, others have been faulted off near the surface, and still others have been covered by formations deposited later than the ores. A fissure across a sedimentary series may end abruptly just below or at a bed of shale, and the ore that fills it will then be exposed only where the shale has been eroded away. The portion of a lode that is now capped by an impervious shale will not have been enriched by oxygenated waters unless, because of certain structural conditions, such waters were conducted laterally below the shale bed to the lode. Such structures as thin saddle reefs, thin anticlines, and thin flatlying beds are not particularly favorable to extensive sulphide enrichment, because they may be eroded in comparatively short time and because the conditions below the deposits they contain are not likely to be so favorable to precipitation as they are in deposits or in parts of deposits that are underlain by sulphide ores. In the absence of material below that may react with the solutions and readily cause precipitation, the metals are likely to be scattered. Nearly vertical or steeply dipping tabular deposits are in a position favorable for secondary concentration, but sulphide enrichment may be extensive also in large isodiametric deposits, or in thick deposits that stand in any attitude.

Deposits that outcropped at one time but are now covered by sedimentary rocks or by later lava flows may have been exposed to weathering and may have been enriched by oxygenating water before the beds covering them were laid down. It can not safely be assumed that the rich ores below the beds covering such deposits are primary and therefore likely to extend downward to indefinite depths. The secondary zones would obviously be related to a topography that existed long ago and not to the present one.

Systems of postmineral fractures in ore and country rock are structural features of obvious importance in the consideration of the enrichment of any ore deposit.

\section{GLACIATION.}

In comparatively late geologic time a considerable portion of North America was capped by a continental ice sheet, which removed by erosion the loose débris and the surface rock over great areas. Glaciation was most extensive in northern latitudes, but the continental glacier extended southward as far as Ohio and Missouri rivers, and smaller glaciers accumulated in the more lofty mountain ranges of 
the American Cordillera. Many of the ore deposits that lay in the paths of the glaciers were planed off, and the ores in their upper zones were scattered in the rocky material which was left when the ice had melted. Erratic fragments of such deposits have been carried far from their sources and have been the cause of much fruitless prospecting.

The outcrop of an ore body may be removed gradually by erosion by water, but weathering generally precedes erosion. The solutions may leach the valuable minerals from the outcrop and may precipitate them at a lower level, where they will be preserved. But weathering does not attend erosion by ice, and chemical action at low temperatures is slight; consequently the metals present in the portions of the deposits that are removed are likely to be scattered. The extent to which the ore deposits in a glaciated region were weathered or otherwise altered by surface agencies before the glacial period began can not be estimated. The amount of rock removed by the continental ice sheet is known to be considerable, however, for the drift which it deposited is in many places more than 200 feet thick. It is probable that glacial erosion was in places equally great or greater. Whatever the amount of ice erosion, it appears to have been sufficient to remove the highly altered zones in most parts of northern North America.

As stated already, the processes of solution and enrichment are retarded in regions of low temperature. The areas in which ice erosion has been most vigorous are those in which the lower temperatures prevail to-day, and there is reason to suppose that the deposits in these areas were not so deeply altered before the glacial epoch as were similar deposits at lower latitudes. In Canada and in Alaska there are few large deposits of sulphide ores which are clearly of secondary origin. If the deposit at the Bonanza mine in the Chitina copper region, Alaska, is primary no large rich secondary sulphide deposits in Alaska are known to me. (See pp. 17 and 215.) The sulphide ores now exploited in Canada, except possibly the deposits at Cobalt, in the silver-bearing region of Ontario (which some have considered of secondary origin), and certain well-authenticated examples in British Columbia, are generally believed to be primary. I know of no important secondary deposits in New England. Small deposits of chalcocite ores were exploited in the Ely district, Vermont. In a copper deposit at Milan, N. H., where the sulphides outcrop at the very surface, no considerable amount of oxidation has taken place below 30 feet, and in general oxidation is trivial at even shallower depths. Only a little chalcocite enrichment has taken place, the secondary ore consisting of primary yellow sulphides coated with thin films of chalcocite, adding to its value probably not more than 1 per cent. 
In Norway and Sweden, according to Vogt, ${ }^{1}$ the surface has been polished clean by the Quaternary ice sheet, and secondary alteration is insignificant.

Glaciers do not erode their beds equally at all places. In their higher portions, where the ice is accumulating, pressures are greater, the ice is more rigid, and erosion is more vigorous. Near the margins, where the ice is melting, deposition exceeds erosion and the deposit of drift protects the surface from wear. These differences are very conspicuous in some mountainous sections of the West where the glaciers covered only portions of the country and the processes are more clearly shown. In some of the ranges of Montana, Colorado, and Utah, where ore deposits are numerous and varied, the evidences of mountain glaciation are conspicuously preserved. At some places the mountain glaciers seem to have removed very little of the altered ore, for the secondary sulphide zones and even the oxidized ores are intact, and some of these appear to be too extensive to have formed since the Quaternary glacial epoch. The Amethyst lode at Creede, Colo., has an extensive secondary zone, and one end of this lode was overridden by the ice in late geologic time. In general, erosion by mountain glaciers has been localized, the maximum wear taking place near the heads of the glaciers.

Erosion by the continental glaciers is also somewhat erratic, for great differences in the effect of the action of ice may be seen in a comparatively small area. In the Mesabi range of Minnesota the hard, fresh country rock is polished clean in places, whereas a few rods away and at but slightly lower elevations thick bodies of cellular, almost powdery iron-oxide ore remain intact. These facts suggest that other important secondary zones may be encountered when the area overridden by the continental ice sheet is more thoroughly developed.

\section{THE UNDERGROUND CIRCULATION.}

\section{OPENINGS IN THE EARTH'S CRUST.}

As emphasized by Van Hise in his treatise on metamorphism ${ }^{2}$ the outer part of the earth's crust may be divided into three zones, differentiated by character of deformation-an upper zone of fracture, a lower zone of flowage, and a middle zone of combined fracture and flowage. The zone of fracture is near the surface. The openings in the rocks of this zone are comparatively stable because the weight of the overlying load of material is less than the crushing strength of the rock. At greater depths, where the differences in the stresses exceed the strength of the rocks, openings, if formed, would almost

1 Vogt, J. H. L., Problems in the geology of ore deposits, in Pošpny, Franz, The genesis of ore deposits, 1902, p. 675.

- Van Hise, C. R., A treatise on metamorphism: Mon. U. S. Geol. Survey, vol. 47, 1904, pp. 187-191; Prinelples of pro-Cambrian North American geology: Sixteenth Ann. Rept. U. S. Geol. Survey, pt. 1, 1896, p. 589. 
immediately be closed by pressure. It is estimated that for all but the strongest rocks flowage would begin at depths not greater than 5 or 6 miles, where the weight of the overlying mass is greater than the crushing strength of the rocks, but there are some reasons for extending this estimate of the zone of fracture to even greater depths. This problem has recently been investigated experimentally by F.D. Adams ${ }^{1}$ and mathematically by L. V. King. ${ }^{2}$ Small holes were bored in cylinders of granite that were inclosed in hollow cylinders of nickel steel. Thus confined, the granite sustained loads of nearly 100 tons per square inch, a load more than seven times as great as that which will crush it at the surface of the earth in the usual laboratory tests. Adams concludes that, under the conditions of pressure and temperature that are believed to prevail within the earth's crust, cavities and fissures may exist in granite to a depth of at least 11 miles and may exist at still greater depths if they are filled with water, gas, or vapor, owing to the pressure exerted by the liquid or gas on theirinner surfaces.

Sulphide enrichment, however, is probably confined to the upper part of the zone of fracture, and although transfers of certain materials may take place in the deeper zones, these do not come within the scope of this investigation. The deepest bodies of secondary sulphide ores now exposed lie at comparatively shallow depths; most of them less than 1,000 feet below the surface, and nearly all that have been developed lie at depths less than 2,000 feet. The depth at which precipitation takes place depends not only on the rate at which the solutions are carried downward but also on the rate at which they react on the walls of their conduits. Although openings may exist at depths of several miles, they would not become channels of circulation unless they were connected. There is without doubt a tightening of the rocks a few hundred feet below the surface, for, as pointed out by Kemp ${ }^{3}$ and by Finch, ${ }^{4}$ the lower levels of many deep mines are dry.

\section{THE LEVEL OF GROUND WATER.}

The terms "water table" and "level of ground water" are generally used to describe the upper limit of the zone in which the openings in rocks are filled with water. This upper limit of the zone of saturation is not a plane but a warped surface. It follows in general the topography of the country but is less accentuated. It is not so deep below a valley as below a hill but rises with the country toward the hilltops and in general is higher there than in the valleys. Although the water in the zone of saturation does not move rapidly,

\footnotetext{
${ }^{1}$ Adams, F. D., An experimental contribution to the question of the depth of the zone of flow in the earth's crust: Jour. Geology, vol. 20, 1912, pp. 97-118.

2 King, L. V., On the limiting strength of rocks under conditions of stress existing in the earth's interior: Jour. Geology, vol. 20, 1912, pp. 119-138.

$3 \mathrm{Kemp}$, J. F., The role of the igneous rocks in the formation of veins, in Pošepny, Franz, The genesis of ore deposits, 1902, p. 695.

- Finch, J. W., The circulation of underground aqueous solutions and the deposition of lode ores: Proc. Colarado Scl. Soa, vol. 7, 1904, pp. 193-252.
} 
it is not stationary. If there is a lower outlet, it will move toward that point. Its movements are slow, however, and it may follow a very circuitous route before it issues again at the surface. It follows the paths of least resistance, and if these are downward the water may sink to great depths before it rises, under pressure, to make its exit at some point which is lower than that at which it first entered the belt of saturation. Thus the water table may be considered a kind of indicator that registers the differences between the loss or leakage of the zone of saturation and the addition from the surface.

As the country is eroded, the water level moves downward and, within certain limits also, it changes with the seasons. In dry years it is deeper than in wet years, and in dry seasons it is deeper than in wet seasons. The difference of elevation between the top of this zone in a wet year and in a dry year is normally greater under the hilltop than on the slopes and in the valleys. In mines where the ground is open the level of ground water probably changes with every considerable rain. Consequently there is a zone that is above ground-water level in dry periods but below it in wet periods, and in moist hilly countries this zone may be of considerable vertical extent. Thus the water table oscillates, though in general it moves downward with degradation of the land surface.

\section{THE VADOSE CIRCOLATION.}

Of the rain that falls $e_{e}$ on the surface a part is drained off by rills and streams, another part is evaporated, and still another part soaks deep into the ground, passes downward, and is added to the water of the zone of saturation. The zone mentioned under the preceding heading - a zone that lies above the zone of saturation and may be relatively dry during a dry period but soaked with water after a wet period-includes openings which in a relatively dry time are filled with air; consequently the water that soaks into the ground after a subsequent rain or snow is aerated and thus becomes a more active agent of solution. The downward movement of such water toward the zone of saturation. has been termed the "vadose" 1 circulation. The depth or thickness of this vadose zone is variable, for its lower limit depends on the variable level of ground water. Near permanent streams or lakes and other bodies of water this limit is not much higher than they are. In moist hilly countries its depth from the surface varies from a few feet to several hundredfeet. In arid regions, where the rainfall is low and evaporation is rapid, this zone may extend to much greater depths. It is, in the main, a zone

1 Pošepny, Franz, The genesis of ore deposits, 1902, p. 18. Pošepny includes in the "vadose" circulation water below the "permanent water lovel." 
of solution; consequently, its rocks are open and circulation within it is comparatively rapid.

\section{THE DEEPER CIRCULATION.}

The circulation of the water in the belt of saturation depends on the relief of the country and on the number, continuity, spacing, and size of the openings in the rocks. Under hydrostatic head the waters in this zone move to points of less pressure and issue at points lower than those of entry. If the deposit is tight and there are no deep outlets the principal movement is shallow, following down the grade of the undulating water table. As a rule movement in the deeper zone is much slower than in the vadose zone, because the openings åre less abundant and also because they are smaller, so that friction on their walls is greater. Some have maintained that the deeper circulation is fairly vigorous, but so far as may be inferred from the developments of deep mines it appears that the underground circulation, in many places at least, is exceedingly sluggish. The depths to which the solutions descend is a question concerning which there are great differences of opinion. In some rocks, under favorable structural conditions, surface waters are conducted, in porous beds or along fractured zones, several thousand feet below the surface, but in other rocks little or no water is collected at depths of more than a few hundred feet.

The shallowness of the zone of the meteoric circulation has been emphasized by Kemp ${ }^{1}$ and by Finch. ${ }^{2}$ In the copper-bearing region of Keweenaw Point, Mich., the lower ends of several shafts that penetrate many layers of bedded rocks are dry and dusty. One of these shafts is sunk about a mile befow the surface, but no water is raised from the deeper levels. At Przibram, Bohemia, no water is raised from depths below 2,500 feet, although the workings extend below 3,500 feet. The water raised in the Dives-Pelican mine, Georgetown, Colo., from the sump, 2,000 feet below the surface, was not greater in quantity than that which was pumped from the mine when the bottom of the shaft was at higher levels. The drainage tunnels at Cripple Creek become nearly dry a few years after they are run, indicating that the waters in that area are stored in the funnel of the volcanic complex which is surrounded by relatively impervious granite and crystalline schists. ${ }^{3}$ In the lower levels of deep mines of Butte, Mont., there is very little water except that which flows in from higher levels. In many comparatively deep mines of the arid

\footnotetext{
1 Kemp, J. F., The rôle of the igneous rocks in the formation of veins, in Pošepny, Franz, The genesis of ore deposits, 1902, pp. 681-809.

${ }^{2}$ Finch, J. W., The circulation of underground aqueous solutions and the deposition of lode ores: Proc. Colorado Sci. Soc., vol. 7, 1904, pp. 193-252.

${ }^{3}$ Lindgren, Waldemar, and Ransome, F. L., Geology and gold deposits of the Cripple Creek district. Colorado: Prof. Paper U. S. Geol. Survey No. 54, 1906, p. 238.
} 
Southwest no body of standing water has been encountered. At Tintic, Utah, according to Finch, ${ }^{1}$ water for drilling is conducted into the mines from the surface. Many deep bore holes sunk in search of oil and water have proved to be dry. These and many other examples indicate that the water circulation is exceedingly sluggish in some regions a short distance below the surface.

On the other hand, it should be noted that large volumes of water were lifted for considerable periods from deep levels of the Comstock lode, of the Granite-Bimetallic mine in Montana, of the Commodore mine at Creede, Colo., and of a great many other mines that have been developed more than 2,000 feet below the surface. From this it appears that local differences in the underground circulation are extreme. The amount of fracturing of the deposits and especially the size of the openings seem to be the most important factors controlling the rate of the circulation. Friction that retards flow multiplies with decrease in size of channels.

\section{THE REGION OF NEARLY STAGNANT WATERS.}

The zone of the deeper circulation varies greatly in depth and vertical extent. Its water is discharged at points that are not lower than the lowest elevation of the country, and if numerous points of discharge are located along a lode that outcrops at several different elevations there will be a considerable lateral movement of the waters toward these, for the solutions move to points of less pressure. If lower rocks are saturated and their openings are filled, the solutions descending from above will find any lateral outlet that is available. In some deposits the solutions doubtless descend to points lower than the lowest outlets and rise again to issue at such outlets, but such circulation is probably slight compared to the circulation that keeps closer to the surface owing to the nearness of points of issue which are located at the surface. Where there are structures that afford passages like inverted siphons there may be a considerable movement of water below the lowest outlet, but under conditions of fairly regular spacing of openings along the lode the circulation becomes less and less vigorous as depth increases below the lowest outlet. There is thus a division, probably everywhere somewhat indefinite, between the sluggish deeper circulation and a zone of static or nearly stagnant waters below it. This conception has been clearly developed by Finch in his paper on the circulation of underground waters. ${ }^{2}$ There is much evidence that in some rocks the top of this zone lies within a few hundred feet of the surface or even less, but where there are deep open fissures it may be much deeper. Finch cites considerable evidence to show that rocks are generally dry below

1 Finch, J. W., The circulation of underground aqueous solutions and the deposition of lode ores: Proc. Colorado Sci. Soc., vol. 7, 1904, p. 216.

Idem, p. 209. 
depths of 1,000 or 1,500 feet, except where they are strongly fractured. Long dry crosscuts, so familiar to all who have worked in deep mines, point clearly to this conclusion.

\section{THE SEVERAL SUCCESSIVE ZONES.}

\section{DOWNWARD CHANGE IN SULPHIDE DEPOSITS.}

As is clearly set forth by R. A. F. Penrose, jr., S. F. Emmons, W. H. Weed, and others, many sulphide deposits show characteristic changes from the surface down the dip. At and near the surface the deposits are generally oxidized and stained with limonite. The outcrop and the upper part of the oxidized portion of the deposit may be poor. Below this there may be rich oxidized ores; still farther down, rich sulphide ores; and below the rich sulphides, ore of relatively low grade. This lowest ore is commonly assumed to be the primary ore, from which the various kinds of ore above have been derived. The several kinds of ore have a rude zonal arrangement, the so-called "zones" being, like the water table, highly undulatory. They are related broadly to the present surface and generally to the hydrostatic level but may be much more irregular than either, for they depend in large measure on the local.fracturing in the lode which controls the circulation of underground waters. Any zone may be thick at one place and thin or even absent at another. If these zones are platted on a longitudinal vertical projection it is seen that the primary sulphide ore may here and there project upward far into the zone of secondary sulphides, or into the zone of enriched oxides, or into the zone of leached oxides, or may even be exposed at the surface. The zone of sulphide enrichment (which is not everywhere present) may project upward far into the zone of rich oxidized ore, or into the zone of leached oxides, or may outcrop at the surface. The zone of sulphide enrichment nearly always contains considerable primary ore, and very commonly the so-called secondary ore is merely the primary ore containing in its fractures small seams of rich secondary minerals. The zone of enriched oxides is generally found above the lowest level reached by the water table. This zone in places extends to the outcrop. The zone of secondary sulphides in moist countries is in general below the water level. In arid countries it may be partly or entirely above the water level.

All these zones except that of the primary ore are, broadly considered, continually descending. Ore taken from the outcrop may represent what was once primary ore; afterward, enriched sulphide ore; still later, oxidized enriched sulphide ore; later still, leached oxidized enriched sulphide ore; and finally it became the surface ore or gossan. Through more rapid erosion at some particular part of the lode any one of these zones may be exposed, and hence an outcrop of ore of any character is possible. 
THE OXIDIZED ZONE.

\section{CONDITIONS IN THE OXIDIZED ZONE.}

In the presence of air and water sulphide ores break down and form soluble salts and minerals that are stable under surface conditions. No metallic sulphide that is long exposed to the action of these agents remains unaltered. Iron sulphides, which are present in practically all deposits of sulphide ores, are changed to iron oxides, and such a change is attended by the liberation of iron sulphates and sulphuric acid, which under favorable conditions dissolve many of the minerals. In many deposits relatively stable basic iron sulphates are formed, but even these eventually break down.

The oxidizing zone is in the main the zone of solution. Precipitation also takes place in this zone, especially the precipitation of the oxides and hydrous oxides of iron, aluminum, manganese, and silicon. By redeposition deposits of the more valuable metals are formed also in this zone. Solution generally exceeds precipitation, however, and by solution the mass is reduced and open spaces are enlarged. In limestones many of these spaces, called "watercourses," are large enough for a man to pass through. The increase in the size and in the volume of the openings renders the downward circulation comparatively free in the zone of oxidation. Regarding the processes of solution at Bisbee, Ariz., where oxidized ores are exceptionally developed, I quote the following from Ransome: ${ }^{1}$

The most marked physical effect of the oxidation of the ore bodies.has been a great increase in the porosity of the masses acted upon. This, by enabling solutions to percolate easily through the partly oxidized zone, has greatly facilitated the migration and concentratiou of the desulphurized ores and their segregation in workable masses from the bulk of the limonitic and clayey "ledge matter."

The oxidized material is not only more porous but much softer and more plastic than the original mineralized limestone and hence greatly weakens by its presence the rocky structure in which it occurs. The overlying limestones, no longer adequately supported, fissure and settle down upon the soft plastic ore and gangue. The access of solutions is thus still more facilitated, and the processes of oxidation and solution proceed so much the faster. That part of the surface which is underlain by oxidizing ore bodies is thus rendered less resistant to erosion, other things being equal, than the surrounding country.

Some of the metals-for example, gold-dissolve very slowly in the zone of oxidation. If the other materials in an ore deposit are taken away, however, the ore may be enriched by decrease in volume, in the manner elucidated by Rickard. ${ }^{2}$

The hydrous oxides, once formed, are comparatively stable, and under certain conditions the more valuable metals dissolve more

1 Ransome, F. L., The geology and ore deposits of the Bisbee quadrangle, Arizona: Prof. Paper U S. Geol. Survey No. 21, 1904, p. 159.

2 Rickard, T. A., The formation of bonanzas in the upper portions of gold veins, in Pošepný, Franz. The genesis of ore deposits, 1902, pp. 734-755. 
readily than the other vein materials in the oxidized zone. Consequently the oxidized zones are in general leached of the valuable metals. Leaching is generally incomplete, however, for owing to the removal of the outcrops by erosion, new surfaces are presented to attack.

As already stated, the oxidized zone is generally above a secondary sulphide zone. As the latter is the richest part of many deposits and as the zone of oxidation is descending the processes of oxidation attack materials that are comparatively rich. In many deposits the first effect of oxidation is to convert the richer sulphides to rich oxides; consequently the lower part of the oxidized zone may be as rich as or even richer than the secondary sulphide zone.

Since copper may replace iron sulphides almost completely in the altered zones of some deposits the gossans in some regions represent the oxidation product of a chalcocite zone nearly free from iron. Thus the outcrop may be only slightly stained with iron. Some important bodies of copper ores at Butte, Mont., at Morenci, Ariz., at Bingham, Utah, and at Cananea, Mexico, have outcrops composed of lightcolored kaolinized rocks that are not highly ferruginous.

SEGREGATION OF THE METALS IN THE OXIDIZED ZONE.

As a result of surface alteration the metals are at many places segregated in the oxidized zone. At Ducktown, Tenn., a pyritic copper ore is converted near the surface into a high-grade iron ore. Below the iron ore is an exceptionally rich chalcocite ore, and below this the low-grade copper ore, the original deposit from which the iron ore and the rich copper ore have been derived. At Ducktown, as in many other districts, the processes of alteration are clearly related to the water level which divides the zone of solution from the zone of precipitation of copper, but in certain districts where the water level is lower nodules of oxidizing ore show the same zonal arrangement. Many of these nodules or spheres are made up of successive shells, each inclosing a smaller one, like the layers of an onion. Although the spherical shape of some of these nodules may be original, many of them have become rounded by oxidation. Where irregular blocks are inclosed by fractures to which water and oxygen have access, processes of oxidation, extending inward from the fractures to approximately equal depths, tend to round off irregularities of the unaltered mass, because the inequalities are the more exposed. The processes may be compared to concentric weathering at the surface.

At the Southern Cross mine, near Cable, Mont., nodules of goldbearing pyrite are surrounded by shells of limonite which clearly have been derived from the oxidation of the iron sulphide in place. Gold is concentrated in the outer shells by diminution of mass, but volume $72293^{\circ}-$ Bull. $529-13-3$ 
for volume the tenor of the iron sulphide and iron oxide is approximately the same. At Leadville, Colo., according to Ricketts, ${ }^{1}$ nodules of galena carry six times as much silver as the cerusite crusts that surround them. A number of assays cited by S. F. Emmons ${ }^{2}$ show a silver content of 420 ounces per ton of galena and only 28.6 ounces per ton of the corresponding cerusite crusts. In view of the fact that the galena of Carbonate Hill averages only 145 ounces per ton, ${ }^{1}$ these figures seem to indicate addition of silver to the galena, as well as leaching of silver from the carbonate.

To illustrate the separation of copper and iron in the zone of oxidation, I quote from Lindgren, Graton, and Gordon ${ }^{3}$ the following description of oxidizing nodular masses in the Apache No. 2 mining district, New Mexico:

The primary ore consists here of a gangue of extremely coarse calcite with a little iron and practically no magnesia. When this is dissolved in acid there remains a skeleton of small films and grains of quartz whose presence would hardly be expected in the apparently homogeneous cleavage pieces. The calcite contains grains of chalcopyrite and small cubes of pyrite. During oxidation this primary low-grade ore becomes surrounded by crusts of secondary calcite, limonite, hematite, malachite, and chrysocolla. The iron and copper separate, the former being deposited in the recrystallized calcite as hydroxide or oxide, while the copper minerals form a thin crust directly adjoining the primary ore and gradually traveling inward as the oxidation progresses. This is exactly what happens under the more intense conditions of artificial oxidation or the roasting of chalcopyrite in metallurgical work. The heat in the presence of oxygen will gradually concentrate the copper sulphide or oxide in the center of the lump, while the ferric oxide forms a shell which can easily be knocked off.

Considered in more detail, the narrow ring of oxidized copper ore consists of alternate narrow bands of malachite and chrysocolla, the latter being due to the quartz distributed microscopically through primary calcite. The malachite always forms the inner zone and projects into the fresh calcite as tufts of slender needles. In places a thin layer of calcite will separate the copper minerals. The wide outer crust consists of recrystallized calcite which only in part has the same orientation as the central cleavage piece of primary ore. This recrystallized calcite contains limonite in flocculent masses, in places distributed concentrically, but does not carry even a trace of copper. At the outer edge of the specimen the limonite changes to dark-brown hematite.

At Bisbee, Ariz., the segregation of the metals in the zone of oxidation is shown on a grand scale. As stated by James Douglas, ${ }^{4}$ a large mass of ore developed between the 200 and 400 foot levels of the Copper Queen mine consists of a core of compact pyrite very lean in copper surrounded by a shell of rich copper ore. According

\footnotetext{
1 Ricketts, L. D., The ores of Leadville and their modes of occurrence, Princeton, N. J., 1883, p. 37.

${ }_{2}$ Emmons, S. F., Geology and mining industry of Leadville, Colo., with atlas: Mon. U. S. Geol. Survey, vol. 12, 1886, pp. 553-554.

${ }^{3}$ Lindgren Waldemar, Graton, L. C., and Gordon, C. H., The ore deposits of New Mexico: Prof. Paper U. S. Geol. Survey No. 68, 1910, pp. 55-56.

- Douglas, James, The Copper Queen mine, Arizona: Trans. Am. Inst. Min. Eng., vol. 29, 1900, p. 531.
} 
to Ransome, ${ }^{1}$ a mass of pyrite was noted on the 1,000 -foot level of the Lowell mine, lying generally parallel with the bedding of the limestones and in contact with partially oxidized ore both above and below. Some native copper was seen in the oxidized ore close to the pyrite. Similar residual masses of worthless pyrite surrounded by good ore, usually containing chalcocite, were seen on the 1,050-foot level of the Calumet \& Arizona mine.

The processes that operate to form the small nodules are probably similar to those that operate to form the larger masses. Many details of the chemistry of these processes have not been worked out, but it is generally recognized, that oxidation favors the solution of some compounds and the precipitation of others. Dilute acid in the presence of air dissolves the sulphides of both copper and iron. Iron, but not copper, is precipitated by hydrolysis of sulphates. Dilute acid in the absence of air dissolves iron sulphide but not copper sulphide, for copper sulphide is precipitated at the expense of iron sulphide if air is excluded. The spherical bodies of enriched sulphide ore in the zone of oxidation, which are crusted with lowergrade, presumably leached oxidizing ore, doubtless illustrate in a small way the same processes that result in the rearrangement of the metals in the several zones that are related to depth.

The separation of lead carbonate and zinc carbonate during the oxidation of ore bodies containing zinc and lead sulphides is conspicuously shown in some districts, especially in ore bodies inclosed in limestone. At Leadville, Colo., deposits of sphalerite, galena, and pyrite are overlain by large oxidized ore bodies, some of which consist of argentiferous cerusite containing but little zinc and others of iron-stained smithsonite containing. little lead. At some places a zone of smithsonite is below one of lead carbonate. At the Kelly mine, in the Magdalena district, N. Mex., these processes have taken place on a smaller scale but are very clearly indicated. There, according to Lindgren, Graton, and Gordon, ${ }^{2}$ the primary ore consists of zinc blende, magnetite, a little pyrite, and galena. As stated by these writers-

The depth of oxidation is about 300 feet. *** In the oxidized stopes nearer the surface the zinc and lead part company. The oxidized zinc ores form wide stopes in which caves large enough for a man to crawl into are coated with beautiful botryoidal, light-green masses of smithsonite. The crust of this material is almost 3 inches thick, and underneath is a dark powdery material rich in manganese but also containing much zinc. The lead stopes are much smaller and are composed of almost pure "sand carbonate" with occasional bunches of galena.

1 Ransome, F. L., The geology and ore deposits of the Bisbee quadrangle, Arizona: Prof. Paper U. S. Geol. Survey No. 21, 1904, p. 146.

${ }^{2}$ Lindgren, Waldemar, Graton, L. C., and Gordon, C. H., The ore deposits of New Mexico: Prof. Paper ठ. S. Geol. Survey No. 68,1910 , p. 55. 


\section{DEPTH OF THE OXIDIZED ZONE.}

The depth of the zone of oxidation and the extent of oxidation within that zone depend upon the permeability of the ore and its character and composition. Conditions differ greatly in different districts and even in different deposits in the same district. The depth of thorough oxidation is generally less than the depth of the vadose circulation, for oxidation follows the depression of the water level. Where the ground-water level has been depressed by relatively rapid climatic change rather than by the gradual downward migration of ground water that attends the normal degradation of a country, the rate of its-depression may be more rapid than that of the zone of oxidation, and in consequence the sulphide ores may be marooned in the vadose zone. In an arid country oxidation is probably slow, for it depends in a measure on the supply of oxygenbearing waters. Thus at Tonopah, at Morenci, and in some other districts in the Southwest the lower limit of oxidation has lagged far behind the downward-migrating water level.

Some deposits are oxidized to great depths. At Bisbee, according to Ransome, ${ }^{1}$ partial oxidation has been noted at depths more than 1,600 feet below the surface. At Tintic recent developments have exposed oxidized ores more than 2,000 feet below the surface. The Old Abe mine, in the White Oaks district, Lincoln County, N. Mex., according to Lindgren, Graton, and Gordon, has been worked to a depth of 1,380 feet, yielding rich oxidized ores. ${ }^{2}$ The water level in this mine is 1,300 feet below the surface. In the Brooklyn mine at Bingham, Utah, ${ }^{3}$ oxidation is said to extend 1,450 feet below the surface. In the Snowstorm mine, in the Cœur d'Alene district, Idaho, according to Ransome, carbonates of copper are found about 1,200 feet below the outcrop of the lode. At Creede, Colo., partial oxidation has extended locally more than 1,000 feet below the surface.

At Tonopah, Nev., ${ }^{5}$ the depth of oxidation is variable. In veins that outcrop oxidation has taken place locally to depths greater than 700 feet. Veins which do not outcrop but which are capped by volcanic rocks later than the ore show comparatively little oxidation. A single fracture line or a fault line may divide the oxidized from the unoxidized ore and rock. In this district no standing ground

\footnotetext{
1 Ransome, F. L., written communication.

${ }^{2}$ Lindgren, Waldemar, Graton, L. C., and Gordon, C. H., The ore deposits of New Mexico: Prof. Paper U. S. Geol. Survey No. 68,1910, p. 60.

${ }^{8}$ Boutwell, J. M., Economic geology of the Bingham mining district, Utah: Prof. Paper U. S. Geol. Survey No. 38, 1905, p. 215.

- Ransome, F. L., and Calkins, F. C., The geology and ore deposits of the Coeur d'Alene district, Idaho: Prof. Paper U. S. Geol. Survey No. 62, 1908, pp. 150-152.

- Spurr, J. E., Geology of the Tonopah mining district, Nevada: Prof. Paper U. S. Geol. Survey No. 42, 1905, p. 80.
} 
water has been encountered in the mine workings, which extend to depths greater than 1,100 feet. $^{1}$

At Przibram, Bohemia, in a comparatively moist climate, oxidation extends, according to Beck, from 200 to 900 feet below the surface. In some other moist districts, as at Ducktown, Tenn., the oxidized ores are not more than 100 feet below the present surface.

At Butte, Mont., according to Reno Sales, ${ }^{2}$ in the vicinity of the St. Lawrence and Mountain View mines, the depth of oxidation is nearly 400 feet, although in many parts of the camp it is only 10 feet. The depth of oxidation in this district depends largely on the composition of the country rock-to a greater degree, in fact, than on the topographic features. The more complete the alteration and pyritization the greater the depth of oxidation. In the central copper area, where the "granite" is strongly altered and pyritized, the upper limit of sulphides is roughly a horizontal plane, although the surface contours in the same area show variations of 300 feet. Over the remainder of the copper area the average depth of oxidation is approximately 50 feet. The depth of oxidation in the veins is influenced to a slight degree by the physical character of the veins themselves. Under like conditions a quartz vein is oxidized to a greater depth than a fault or "granite vein," owing to the greater impermeability of the clay and crushed "granite" of veins of the latter class.

At Tintic, Utah, the limit of oxidation in fractured limestone is at least 2,000 feet deep, but the ground-water level and zone of unaltered sulphides in igneous rocks scarcely half a mile away is only 200 or 300 feet from the surface. ${ }^{3}$

At Cripple Creek, Colo., partial oxidation is found in some places at depths of 1,200 feet, ${ }^{4}$ but in other places it is relatively shallow.

\section{SUBMERGED OXIDIZED ORES.}

As already stated, the oxidized ore is generally above the groundwater level, and in arid countries oxidation is seldom complete at depths considerably above that level. In deep mines little smears or veinlets of oxidized material, generally a mixture of kaolin and limonite or of kaolin and manganese oxide, are found at considerable depths. In moist countries such veinlets were probably deposited below the water level. As the solutions descend, their acidity is reduced, and some of the metals which may be held in acid solutions would be precipitated by a decrease of acidity.

\footnotetext{
1 Spurr, J. E., op. cit., p. 98.

Sales, R. H., Superficial alteration of the Butte veins: Econ. Geology, vol. 5, 1910, p. 19.

Tower, G. W., Smith, G. O., and Emmons, S. F., Tintic Special folio (No. 65), Geol. Atlas U.S., U.S. Geol. Survey, 1900, p. 5. Emmons, S. F., The secondary enrichment of ore deposits, in Pošepny, Franz, The genesis of ore deposits, 1902, p. 438. Lindgren, Waldemar, oral communication.

- Lindgren, Waldemar, and Ransome, F. L., Geology and gold deposits of the Cripple Creek district, Colorado: Prof. Paper U. S. Geol. Survey No. 54, 1906, p. 196.
} 
Extensive oxidation is probably limited to those parts of deposits that lie above the ground-water level at the time of oxidation. In some deposits, however; the ores are extensively oxidized below the water level. According to B. S. Butler, ${ }^{1}$ the ores of the Harrington-Hickory mine, near Milford, Utah, are oxidized at least 100 feet below the present water level. At Bisbee, Ariz., the depth of oxidized ore ranges from 200 to 1,600 feet and the deeper oxidized ores are submerged. As shown by Ransome (p. 182), the altered ores are related to a tilted pre-Comanche erosion surface rather than to that existing to-day.

Where ore bodies are extensively oxidized far below the groundwater level it is reasonable to infer that the level of the ground water has risen. The amount of atmospheric oxygen that water may dissolve and carry far below the water level is very small (see p. 90) and probably would be insufficient to oxidize large masses of sulphides, even in a comparatively long period.

\section{TRANSITIONS BETWEEN OXIDIZED AND SULPHIDE ORES.}

In moist countries, where the level of ground water is near the surface, the transition between the almost completely oxidized ore and the unoxidized sulphides is generally abrupt. This is especially noticeable in the pyrrhotitic copper ores of Ducktown, Tenn., where the contact between the two is at some places as sharp as a knife blade. In pyrrhotitic ores of the Encampment district, Wyoming, chalcocite ores occur immediately below the gossan. ${ }^{2}$ In the pyritic copper ores of Butte, Mont., according to Sales, the transition is sharp. He says: ${ }^{3}$

Examined from the surface downward the oxidized portion of a copper vein will show but little variation in physical character or mineral composition between the outcrop and the sulphide ore. The line of separation marking the change from oxidized to sulphide ore is very sharp and clean cut. There is no partial oxidation of the vein; no mixture of sulphides and oxides. The entire change in any single cross section of a vein takes place within 2 or 3 feet vertically. Generally the sulphide ore, through slight changes in the relative abundance of certain minerals, indicates the proximity of the oxides, while in the case of the oxides there is seldom, if ever, any change to indicate a nearness to sulphides. In the copper belt the minor veins, stringers, iron pyrite seans, country rock, etc., are all oxidized and bear the same relation to the surface and to depth of oxidation as do the large veins.

In some other districts, however, there is no such sharp dividing line between the oxide and the sulphide ore. At Bingham, Utah, according to Boutwell, ${ }^{4}$ the transition from the zone of oxidation to

1 Oral conımunication.

2 Spencer, A. C., The copper deposits of the Encampment district, Wyoming: Prof. Paper U.S, Geol. Survey No. 25, 1904, p. 55:

Sales, R. H., Superficial alteration of the Butte veins: Econ. Geology, vol. 5, 1910, p. 19.

4 Boutwell, J. M., Economic geology of the Bingham mining district, Utah: Prof. Paper U. S. Geol. Survey No. 38, 1905, p. 221. 
the zone of sulphide enrichment is gradual, as it is also at Morenci, Ariz., where the zone of secondary sulphides is oxidized through a considerable vertical distance. Says Lindgren: ${ }^{1}$

The oxidation does not extend down to any well-defined water level, which must be far below the deepest workings, but acts most irregularly, sometimes leaving fresh metamorphic limestone at the surface and again reaching down to a depth of 4.00 feet along fissures and faults. The present ore bodies probably fell an easier prey to oxidation by reason of their richness in sulphides and their favorable exposure to percolating waters. In such position are the upper ore bodies of the Detroit and Manganese Blue. In other cases the oxidation was facilitated by means of fault planes and porphyry dikes.

At Bisbee, Ariz., the zone of transition between the oxide and sulphide ore is extensive. According to Ransome: ${ }^{2}$

Within the transition zone between completely oxidized and unaltered sulphide ores, which has a maximum depth or thickness of about 900 feet, the oxidizing processes are controlled to a large extent by recent irregular fissuring and by the relative permeahility of the various sulphide masses to generally descending solutions. Fissures cutting through masses of lean pyrite are almost invariably accompanied by streaks of rich ore, often containing chalcocite, together with cuprite and native copper. Where there are several such fissures near one another important ore bodies result. The general association of profitable ore with fissured, broken, permeable ground is well recognized in practical operations and turned to good account in underground exploration.

THE SECONDARY SULPHIDE ZONE.

\section{POSITION AND EXTENT.}

The secondary sulphide zone is generally below a zone of oxidation. It is not everywhere developed, not even in copper ores that are capped with gossan. Examples of such deposits are cited on a following page. In many deposits the transition between the oxidized and secondary sulphide zone is sharp, being essentially at the ground-water level. In such deposits the secondary ores extend downward to various distances below the water level. The vertical extent of the secondary zone differs widely in different districts. In some of the districts of the southern Appalachians the chalcocite zones occupy only a few feet vertically. At Ducktown, Tenn., in all except one mine the average thickness of the secondary chalcocite zone is probably between 3 and 8 feet, but some secondary chalcopyrite is developed far below this zone. In the East Tennessee mine, in this district, the vertical range of chalcocite is about 125 feet. In the Encampment district, Wyo., the vertical extent of chalcocite is at least 200 feet. In the disseminated deposits in porphyry at Bingham, Utah, the zone of workable sulphides, mainly chalcocite

\footnotetext{
1 Lindgren, Waldemar, The copper deposits of the Clifton-Morenci district, Arizona: Prof. Paper U.S. Geol. Survey No. 43, 1905, p. 197.

2 Ransome, F. L., The geology and ore deposits of the Bisbee quadrangle, Arizona: Prof. Paper U. S. Geol. Survey No. 21, 1904, p. 145.
} 
and chalcopyrite, has an average vertical extent of 418 feet, ${ }^{1}$ and owing to the rugged topography the vertical range is much greater. At Morenci, Ariz., the belt of maximum deposition of secondary chalcocite is in general from 200 to 400 feet below the surface, although veins of chalcocite are said to be encountered at greater depths, especially in the Coronado mine. In this mine also, according to Lindgren," chalcocite in places reached the surface. At Bisbee, Ariz., chalcocite, partly oxidized, is found within 200 feet of the present surface and extends to depths at least 1,500 feet below the surface. At Globe, Ariz., in the Old Dominion mine, chalcocite has been found more than 1,200 feet below the surface and has a vertical range of at least 800 feet. In the Miami Inspiration ore zone, according to current reports, chalcocite is found 900 or 1,000 feet below the surface. In all these districts chalcocite is regarded as a mineral which is in the main if not altogether secondary. At Butte, Mont., chalcocite has been found at depths 2,800 feet below the surface. In the upper levels of the Butte mines secondary chalcocite is abundant, but recent investigations, especially those of Reno Sales, indicate that the chalcocite of the deeper levels is probably primary. Except at Butte no data now available indicate deposition of secondary chalcocite at depths greater than 1,500 feet below the outcrop. It is not at all improbable, however, that secondary chalcocite deposited at greater depths may be revealed by future exploration.

Examples of enrichment of silver sulphide deposits at depths from 1,000 to 1,200 feet below the surface are well authenticated. Doubtless secondary deposits of silver occur at greater depths, but it is questionable how far the several species of the silver-bearing minerals may indicate geologic processes. I know of no examples of the precipitation of appreciable amounts of gold by descending solutions at depths more than 1,000 feet below the surface. In general, gold that is dissolved by surface waters is precipitated at relatively shallow depths.

The data reviewed above show that no definite depth can be fixed below which processes of enrichment are not effective. The maximum precipitation occurs at comparatively shallow depths, however, and there is little reason to suppose that these processes are effectively operative in the deeper part of the zone of fracture. The depth to which the metals are carried depends on local climatic conditions, permeability, and the chemical or mineralogic environment.

\footnotetext{
1 Seventh Ann. Rept. Utah Copper Co., Dec. 31, 1911.

2 Lindgren, Waldemar, The copper deposits of the Clifton-Morenci district, Arizona: Prof. Paper U. S. Geol. Survey No. 43, 1905, p. 210.
} 


\section{RELATION TO THE WATER LEVEL.}

The ground-water level, the so-called water table, has frequently been regarded as indicating the top of the secondary sulphide zone at the time that zone was formed. As has been stated, the water level is not stationary but oscillates, although it tends to move downward as the major drainage channels approach grade. If the water level is comparatively high or if the lode is much fractured, and particularly if it contains large spaces, there is probably but little precipitation of the secondary sulphides above the water level. There are two reasons why this should be true; one is that the solutions descend in open rocks at a comparatively rapid rate through the fractured and partly weathered zone of somewhat cellular ore above the shallow water level, and the other is that several of the sulphides of the more valuable metals that are dissolved readily in an oxidizing environment are not readily precipitated in such an environment. If the rocks are open atmospheric oxygen should find ready access to the ore above the zone of saturation. But even if precipitation should take place the sulphides precipitated would later be exposed again to oxidation and solution.

The sulphides below the water level are protected from the oxygen of the air, however, and solution of some metals is retarded if not prevented. The solution in acid sulphate of copper sulphide, silver compounds, and gold requires an oxidizing agent. It is well known that a small concentration of ferrous sulphate, which is surely present - in the reducing zone below the water level, will drive gold and silver from solution. Copper sulphide, which dissolves readily in sulphuric acid in the presence of air, is not dissolved in its absence. Hydrogen sulphide is generated by the action of acid on several sulphides and in the presence of the faintest trace of hydrogen sulphide copper sulphide is not dissolved-not even in boiling concentrated acid. ${ }^{1}$ Thus it would be supposed that under these conditions the solution of copper, silver, and gold would be inhibited at ground-water level or a short distance below it. Since a liter of water can absorb under surface conditions only about 6.84 cubic centimeters of atmospheric oxygen, the amount carried dissolved, even in a saturated solution, can not be great. The oxygen that is made available by the hydrolyzation of water when ferric sulphate is reduced to ferrous sulphate and that which combines to form the higher oxides of manganese might delay reduction, but the delay would be only temporary. Although oxygen is required for the solution of gold, silver, and copper, the sulphides of zinc and at least some of the sulphides of iron might be dissolved at depths considerably below water level, for they

' Allen, E. 'T., oral communication. 
are attacked by acid sulphate eren in the absence of an oxidizing agent.

Many deposits of secondary sulphide ore in the arid Southwest are well above the present ground-water level. The lower limits of some of these deposits have been reached by mining, and below some of them lie considerable bodies of pyrite and chalcopyrite ore which bave been penetrated by mine workings that encountered no standing underground water. As has been already stated, the climate in this area has changed from humid or subhumid to arid in comparatively recent time, and it is possible that some bodies of secondary sulphide ore have been marooned by the rapid descent of the ground-water level that attended the change. At Morenci, Ariz., nearly all the mines are dry in and below the chalcocite zones of these deposits. Of these Lindgren ${ }^{1}$ says:

Chalcocite perhaps forms at the present time in the upper levels of the belt occupied by this mineral where copper-sulphate solutions from oxidizing chalcocite above are abundant and free oxygen absent. * * * Direct oxidation has, in fact, already penetrated to the deepest levels attained in the pyritic zone; at present it works here chiefly along fissures and seams but is probably slowly spreading.

I regard the chalcocite zone as formed about an ancient water level, much higher than the present. During the epoch of the Gila conglomerate the water level was surely at least several hundred feet higher than it is now, and it was probably still higher during Tertiary time, in which a moist climate most likely prevailed.

\section{PRECIPITATION OF SULPHIDES ABOVE THE WATER LEVEL.}

In arid districts, where the water level lies very deep, the descending metal-bearing solutions may encounter a reducing environment in the so-called vadose zone, especially in rocks that contain only minute openings, through which the water soaks downward from the surface, excluding the admission of any considerable amount of air. It would be supposed that the oxygen present in such waters and in the imprisoned air would be used up before the descending solutions encountered any zone of permanent saturation, or that the solutions might become reduced before reaching ground-water level, so that the metals could readily be precipitated. ${ }^{2}$

Any former water level doubtless maintained the usual relation to the topography that existed when it prevailed, and it is generally untenable to assume that the topography which controlled a former water level in a region where the climate has changed recently was very different in its major features from the present topography. Stope sheets and other available published information show that many of the chalcocite zones in copper deposits of arid regions have

\footnotetext{
1 Lindgren, Waldemar, The copper deposits of the Clifton-Morenci district: Prof. Paper U. S. Geol. Survey No. 43, 1905, p. 206.

2 Finch, J. W., The circulation of underground aqueous solutions and the deposition of lode ores: Proc. Colorado Sci. Soc., vol. 7, 1904, p. 238.
} 
a pretty definite relation to the major features of the present topography, and it therefore seems possible that when they were formed they bore the usual relation to the water level then prevailing. The disseminated chalcocite ores of Miami, Ariz., are, however, not definitely related to the present topography, which was apparently developed after the main period of enrichment. ${ }^{1}$ At Ray also, according to Ransome, ${ }^{2}$ the layer of disseminated chaicocite ore has many irregular undulations that apparently have no dependence on the present topography.

It is not at all unlikely that secondary sulphide ores have formed independently of any present or past water level: As stated by Finch, ${ }^{3}$ deposits exposed to processes of alteration in an arid region may lie in gaseous zones that are analogous to the aqueous zones of more humid regions. Oxygen predominates in the surface zone, whereas carbon dioxide and other heavier gases may prevail at greater depths. Thus in an arid region there may be an oxidizing gaseous zone and below it a reducing gaseous zone in which precipitation may take place in the absence of oxygen. Circulation by evaporation would be possible in the lower zone.

Precipitation by evaporation is undoubtedly a factor to be considered in shallow oxidizing zones and may account for the veinlets of clayey limonite that are found in cracks in some sulphide ores at depths considerably below the zones of nearly complete or welladvanced oxidation. The material precipitated by the evaporation of the mineral waters should be chemically similar to that deposited by evaporation under surface conditions, and, so far as analyses show, mineral waters that accomplish sulphide enrichment generally carry iron, aluminum, and other metals of low value greatly in excess of the more valuable metals. Unless, by processes of selective precipitation, certain compounds only could be removed from the solutions in depth, nearly all of the material dissolved in the oxidizing environment and carried below into the reducing environment would be precipitated. There would be a downward circulation of water and dissolved mineral matter. The upward circulation of evaporated water might carry some of the dissolved salts, but few data are available on this point. Weed states that ferrous, copper, and zinc sulphates are carried by the moisture of air circulating in mine openings. He thus accounts for efflorescence of these salts on mine workings. ${ }^{4}$ Since mineral matter could not readily escape, however, the enrichment that could take place where downward-moving aqueous solutions could not reissue would

\footnotetext{
1 Ransome, F. L., this bulletin, p. 185.

2 Ransome, F. L., this bulletin, p. 187.

3 Finch, J. W., The circulation of underground aqueous solutions and the disposition of lode ores: Proc. Colorado Sci. Soc., vol. 7, 1904, p. 240.

4 Weed, W. H., Geology and ore deposits of the Butte district, Montana: Prof. Paper U. S. Geol. Survey No 74,1512 , p. 99 .
} 
depend on the sum total of the openings available, for appreciable replacement under these conditions would probably not occur. The secondary materials that are deposited under such conditions as a whole would not be much if any richer than the residues of descending waters, although even under these conditions the valuable minerals might be segregated somewhat by selective precipitation.

\section{TEXTURES OF SECONDARY SULPHIDE ORE.}

In the zone of oxidation solution ordinarily much exceeds precipitation. The oxidized ore is almost invariably of spongy, open texture and contains numerous solution cavities. In the secondary sulphide zone solution does not exceed precipitation to the same extent. In the sulphide zone numerous solution cavities may be developed, but these are likely to be filled, partly or completely, by secondary minerals. The texture of secondary sulphide ore varies widely. Some of the chalcocite ore of Ducktown, Tenn., is little more than a sponge of chalcocite from which iron, copper, and other sulphates have been dissolved. On the other hand, some secondary sulphide ores consist largely of massive chalcocite inclosing numerous primary minerals, the pore space in the ores being quite subordinate.

The solution of primary sulphides and the precipitation of secondary sulphides may go on simultaneously, the secondary minerals replacing the primary. The best proof of replacement is offered where the later minerals have assumed the crystal forms of the earlier minerals. Pseudomorphs of chalcocite or covellite after pyrite, chalcopyrite, or zinc blende are the most common. Such replacements of pyrite are clearly shown in the Miami-Inspiration ore zone at Miami, Ariz., ${ }^{1}$ and at other places. Examples scarcely less suggestive are found in districts where masses of primary sulphide not having crystal form but of distinctive occurrence have been replaced by secondary ores. In the No. 20 mine near Ducktown, Tenn., where the primary ore, consisting chiefly of massive pyrrhotite, pyrite, and chalcopyrite, includes small rounded masses of quartz, garnet, and actinolite, the secondary ore consists of chalcocite and other minerals and includes similar rounded masses of gangue minerals partly dissolved. At Morenci, Cananea, Bingham, Ely, Santa Rita, and in other districts containing disseminated deposits of secondary chalcocite, where the mineralized material below the secondary zone consists of a granular or a porphyritic igneous rock containing numerous small masses and veinlets of sulphide ore, chiefly pyrite and chalcopyrite, the same rock in the secondary zone contains small masses and veinlets of chalcocite, with some pyrite and chalcopyrite, showing an arrangement of spacing similar to that shown by the minerals in the lower zone. Such evi-

\footnotetext{
1 Ransome, F. L., Criteria of downward sulphide enrichment: Econ. Geology, vol. 5, 1910, p. 214.
} 
dence of replacement is scarcely less convincing than pseudomorphs having the regular boundaries of older crystals. In some secondary deposits the small rounded. cores of an older sulphide are coated over with shells of the secondary sulphide. As pointed out by Irving, ${ }_{1}$ this in itself is evidence of replacement. That solution and precipitation went on simultaneously is indicated in 'such' deposits by the even spacing of the cores. If solution had been completed before precipitation began, the small, rounded, partly dissolved masses would have settled and would have been massed closer. Of the chalcocite ore of the Old Dominion mine, at Globe, Ariz., Ransome ${ }^{2}$ says:

When the chalcocite is examined closely, particularly with a lens, it shows an indistinct unevenness of texture suggestive of the obscurer forms of pisolitic structure observed in some bauxites. Critical scrutiny of the inclosed grains of pyrite discovers the fact that their outlines are rounded and that the chalcocite has a more or less distinct concentric, shelly structure around each grain. These facts at least strongly suggest that the chalcocite has been formed at the expense of ${ }^{p}$ the pyrite and that the minute structure observable in chalcocite now free from pyrite records the former presence of that mineral and its subsequent replacement by the sulphide of copper.

Much of the material which is generally termed secondary sulphide ore consists essentially of shattered and fractured primary sulphide ore, the cracks in which are filled with later sulphides or with angular fragments of the earlier sulphides crusted over with those that were introduced later. Such textures do not invariably indicate processes of sulphide enrichment by descending solutions. Many authentic examples show that, in the course of primary mineralization, the ore first deposited has been fractured and that solutions from below have deposited later sulphides in the fractures. In many deposits, moreover, the later sulphides are richer than the original fractured ore.

Pseudomorphous replacement indicates a change of physical conditions or of chemical environment. Minerals that were stable under certain conditions have been dissolved and other minerals have simultaneously been deposited. On the other hand, fractured ore cemented by later minerals may be a result of normal and perhaps continued deposition from below. If, however, the minerals that fill the later cracks are those that are commonly formed by descending solutions, and if they do not persist in depth, the assumption that they are secondary may with considerable confidence be regarded as confirmed.

In many deposits the genesis of such later veinlets is perplexing. As the matter now stands, the mineralogic criteria are unsatisfactory, for few if any of the sulphides are formed invariably under a single set of conditions.

The texture of the secondary veinlets is important, however, and it may throw considerable light on their genesis. Concerning this point

\footnotetext{
1 Irving, J. D., Replacement ore bodies, in Types of ore deposits, San Francisco, 1911, pp. 289-290.

2 Ransome, F. L., Geology of the Globe copper district, Arizona: Prof. Paper U. S. Geol. Survey No. 12, 1903, p. 121.
} 
certain observations by Hynes ${ }^{1}$ on ores from the Mina Mexico vein, Sonora, Mexico, are noteworthy. The polished surfaces of several specimens prepared by him showed primary ore composed of pyrite and quartz, not containing any antimony mineral, cut by veinlets of ore composed of tetrahedrite and quartz. In the later veinlets the quartz is everywhere inclosed in the tetrahedrite and is generally idiomorphic. Its crystals are distributed with great regularity through the tetrahedrite, suggesting definite or eutectic proportions.

So far as is now known the crystallization of minerals in eutectic proportions does not occur in descending sulphate waters. The texture of the chalcocite ores of Virgilina should be mentioned in this connection. In the upper levels of the mines the ore is cut by small veinlets of secondary chalcocite, but polished surfaces of ore from the lower levels, as shown by F. B. Laney, ${ }^{2}$ reveal an intimate intergrowth of chalcocite and bornite which suggests the pattern of a graphic granite. Some of Laney's sections ${ }^{3}$ are particularly suggestive of precipitation under conditions that prevail at great depths and of processes of crystallization that are not known to operate under the temperatures and pressures that prevail in the zone of sulphide enrichment.

When in the course of the deposition of ores the minerals are deposited layer on layer in open spaces, the minerals forming the last layer or crust may differ from those formed earlier, and when cavities are broken open the minerals last deposited appear to be of late age. The position of the mineral lining the cavity does not certainly indicate that it was deposited by descending waters, for the last ores deposited by ascending waters in open spaces would be in a similar position. If, however, the walls of cavities and fractures are coated with the hydrous oxides of iron or manganese, and if sulphides have formed along with these oxides, there is small probability of error in determining whether the sulphides were formed by ascending or descending solutions, for the hydrous oxides are rarely deposited with primary sulphide ores. Likewise the intimate association of native metals with such hydrous oxides is generally evidence of deposition by oxidized descending solutions.

\footnotetext{
1 Hynes, D. P., Notes on the geology of the Mina Mexico vein: Econ. Geology, vol. 7, 1912, pp. 280-286. See also Weed, W. H., Geology and ore deposits of the Butte district, Montana: Prof. Paper U. S. Geol. Survey No. 74,1912 , p. 76 (fig. 13, showing chalcocite inclosing idiomorphic crystals of quartz and pyrite).

2 Laney, F. B., The relation of bornite and chalcocite in the copper ores of the Virgilina district of North Carolina and Virginia: Econ. Geology, vol. 6, 1911, pp. 399-411.

s See especially that figured on Pl. VII, fig. 2, in the paper just cited.
} 


\section{ESTIMATES OF VERTICAL EXTENT OF PORTIONS OF LODES ERODED.}

Where there is reason to suppose that the primary ore was of approximately uniform composition before secondary alteration took place, it is possible to estimate the vertical extent of the portion of the deposit that has been eroded. As already stated, the ore in the secondary zone generally contains the valuable metals that were present in the primary ore, those that were leached from the oxidized zone above the secondary sulphide ore, and those that were leached from the portion of the deposit that has been removed-the metals that were carried downward by solutions in advance of erosion.

Estimates made for the Granite-Bimetallic lode, Philipsburg, Mont., indicate that at least 1,600 feet of material like the primary ore in the bottom of the mine was required to supply the valuable minerals in the secondary sulphide zone, in addition to those of the primary ore and any that may have been dissolved from the oxidized zone and reprecipitated below. Estimates for Ducktown, Tenn., on the other hand, show that the valuable minerals in the secondary sulphide zone may be fully accounted for by the reconcentration of copper formerly in the leached zone now exposed, and that the copper that was present in the part of the lodes removed by erosion was scattered, probably while the region was at base-level.

If $x$ equals the vertical extent in feet of the part of the lode which has been removed from above the present apex, $a$ equals the vertical extent in feet of the leached zone, $b$ equals the vertical extent in feet of the enriched zone, $l$ equals the values ${ }^{1}$ remaining in the leached zone, $e$ equals the values in the enriched zone, and $p$ equals the values ${ }^{1}$ in the primary ore, the following formula may be applied to ascertain the number of feet removed:

$$
x=\frac{a(l-p)+b(e-p)}{p}
$$

This formula does not take into account the changes in mass ${ }^{2}$ in the ore itself nor the pore space formed, and it is recognized, of course, that many other factors may modify the results; for the values may not all be reconcentrated, and the primary ore, before alteration and enrichment, may not have been of equal richness throughout the deposit. The estimates therefore give only a rude approximation, but one which may be used, in connection with other geologic data, as a check on conclusions regarding the minimum amount of erosion that has taken place since the primary ore was deposited. 


\section{CHEMISTRY OF SULPHIDE ENRICHMENT.}

\section{EXPERIMENTAL DATA ON THE. SOLUTION AND PRECIPITATION OF THE METALS.}

The oxidation of pyrite is considered by many to proceed as follows: ${ }^{1}$

$$
\mathrm{FeS}_{2}+7 \mathrm{O}+\mathrm{H}_{2} \mathrm{O}=\mathrm{FeSO}_{4}+\mathrm{H}_{2} \mathrm{SO}_{4} .
$$

This equation does not express intermediate steps, nor does it represent the final products. Ferrous sulphate in the presence of atmospheric oxygen will be oxidized to ferric sulphate or to ferric sulphate and ferric hydroxide:

$$
6 \mathrm{FeSO}_{4}+3 \mathrm{O}+3 \mathrm{H}_{2} \mathrm{O}=2 \mathrm{Fe}_{2}\left(\mathrm{SO}_{4}\right)_{3}+2 \mathrm{Fe}(\mathrm{OH})_{3} .
$$

The hydrolyzation of ferric sulphate may first give a basic ferric sulphate, ${ }^{2}$ but this subsequently breaks down, forming ferric hydroxide and sulphuric acid, as indicated below:

$$
\mathrm{Fe}_{2}\left(\mathrm{SO}_{4}\right)_{3}+6 \mathrm{H}_{2} \mathrm{O}=2 \mathrm{Fe}(\mathrm{OH})_{3}+3 \mathrm{H}_{2} \mathrm{SO}_{4} \text {. }
$$

Ferric hydroxide probably corresponds to the mineral limnite, which on dehydration would give limonite:

$$
4 \mathrm{Fe}(\mathrm{OH})_{3}=2 \mathrm{Fe}_{2} \mathrm{O}_{3}+6 \mathrm{H}_{2} \mathrm{O}=2 \mathrm{Fe}_{2} \mathrm{O}_{3} \cdot 3 \mathrm{H}_{2} \mathrm{O}+3 \mathrm{H}_{2} \mathrm{O} \text {. }
$$

According to Stokes ${ }^{3}$ the oxidation of pyrite by ferric sulphate should be regarded as taking place by two independent reactions:

(1) $\mathrm{FeS}_{2}+\mathrm{Fe}_{2}\left(\mathrm{SO}_{4}\right)_{3}=3 \mathrm{FeSO}_{4}+2 \mathrm{~S}$.

(2) $2 \mathrm{~S}+6 \mathrm{Fe}_{2}\left(\mathrm{SO}_{4}\right)_{3}+8 \mathrm{H}_{2} \mathrm{O}=12 \mathrm{FeSO}_{4}+8 \mathrm{H}_{2} \mathrm{SO}_{4}$.

In the presence of air the ferrous sulphate formed would change again to ferric sulphate.

A. N. Winchell 4 treated powdered pyrite containing a trace of copper to dripping aerated water. At the end of ten months 300 grams of pyrite had lost 0.2 gram and the solution circulating through the pyrite had gained, per liter of the solution, the amounts indicated below:

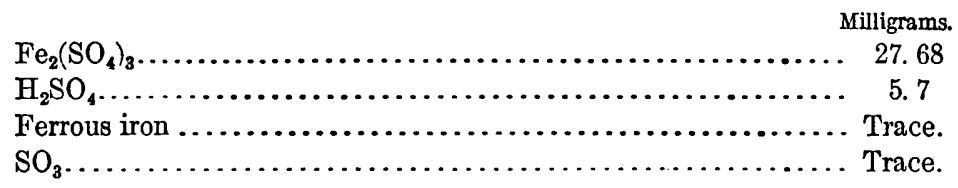

1 Allen, E. T., Sulphides of iron and their genesis: Min. and Sci. Press, vol. 103, 1911, pp. 413-414. Gottschalk, V. H., and Buehler, H. A., Oxidation of sulphides: Econ. Geology, vol. 7, 1912, pp. 15-34.

2 Penrose, R. A. F., jr., The superficial alteration of ore deposits: Jour. Geology, vol. 2, 1894, p. 293. Brauns, Reinhard, Chemische Mineralogie, Ieipzig, 1896, p. 368.

${ }^{8}$ Stokes, H. N., On pyrite and marcasite: Bull. U. S. Geol. Survey No. 186, 1901, p. 15.

4 Winchell, A. N., The oxidation of pyrite: Econ. Geology, vol. 2, 1907, pp. 290-294. 
In the total solution there was-

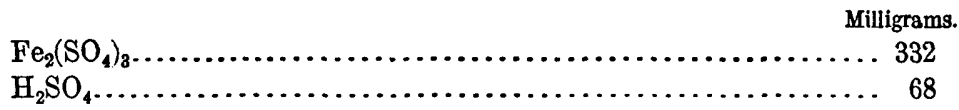

Grout ${ }^{1}$ repeated these experiments, subjecting the powdered mineral to repeated drying. In a year the specimens had lost from 0.015 to 0.057 per cent. These losses are of the same order as those shown by the figures obtained by Winchell, namely, 0.067 per cent.

Buehler and Gottschalk ${ }^{2}$ made numerous experiments with distilled water, leaching powdered sulphides to determine the nature of the alteration products. The finely powdered sulphides were placed upon filter paper spread upon a Hirsch filter plate, which was fitted in a 6-centimeter funnel. The sulphides were then washed twice daily with distilled water, the filtrate being caught in a flat-bottomed flask. The sulphides were treated alone and also when mixed with pyrite or marcasite or some other natural sulphide.

A series of the filtrates obtained from marcasite alone and from marcasite mixed with galena, sphalerite, and copper sulphides were tested for free sulphur dioxide, sulphites, and thiosulphates, but none of these compounds were present.

In experiments with pyrite the residue left on the funnel was treated with carbon disulphide to test for the presence of free sulphur. No sulphur was found in a series of eight experiments, but a 10-pound sample of marcasite similarly treated showed the presence of free sulphur.

Tests for the presence of hydrogen sulphide as a possible decomposition product of these sulphides were made in an apparatus through which air could be drawn. The air was passed slowly through lead solution to free it from any hydrogen sulphide; it was then passed through a tube in which finely ground sulphide was placed; finally the air was again washed in lead solution. The sulphides were washed twice daily with water. After four months' continuous treatment there was no sign of blackening of the lead solution, indicating the absence of even traces of hydrogen sulphide. The following analysis of the solution and precipitate in the flask indicates hydrolysis:

Solution, 1,068 cubic centimeters.

$\mathrm{FeSO}_{4}, 0.0602$ gram; $\mathrm{Fe}_{2}\left(\mathrm{SO}_{4}\right)_{3}, 0.1799$ gram; $\mathrm{SO}_{3}$ (excess), 0.2697 gram; $\mathrm{Fe}_{2} \mathrm{O}_{3}$ (in the precipitate), 0.0218 gram.

The conclusion of Gottschalk and Buehler is that the oxidation of pyrite in water proceeds according to the reaction-

$$
\mathrm{FeS}_{2}+7 \mathrm{O}+\mathrm{H}_{2} \mathrm{O}=\mathrm{FeSO}_{4}+\mathrm{H}_{2} \mathrm{SO}_{4} \text {. }
$$

1 Grout, F. F., The oxidation of pyrite: Econ. Geology, vol. 3, 1908, pp. 532-534.

'Buehler, H. A., and Gottschalk, V. H., Oxidation of sulphides: Econ. Geology, vol. 5, 1910, pp. 28-85; vol. 7, 1912, pp. 15-34.

$72293^{\circ}-$ Bull, $529-13-4$ 
This does not involve the generation of hydrogen sulphide, of sulphur dioxide, or of more than an exceedingly small amount of sulphur.

In this connection it is noteworthy that these experiments were carried on with distilled water with very free access of air. Dilute acid solutions acting upon some sulphides of lead and zinc and upon ferrous iron will generate hydrogen sulphide. (See p. 59.)

In several experiments by Gottschalk and Buehler ${ }^{1}$ the powdered sulphides spread on a filter were washed twice daily with distilled water. In most of these experiments the sulphates were passed through 60-mesh screens and caught on 80 or 100 mesh screens, so that the powders were of approximately equal fineness. In some experiments galena was caught on 200-mesh screens, giving relatively greater surfaces for attack. Equal masses, not equal volumes, of the several minerals were taken.

In most experiments the accumulated washings were about 500 cubic centimeters. Pyrite, marcasite, galena, sphalerite, and enargite were attacked. Each of the metals was oxidized to sulphate and washed through the filter. Pyrite and marcasite were oxidized to ferric and ferrous sulphate and to sulphuric acid. Zinc was oxidized to zinc sulphate and washed through. Galena was oxidized to lead sulphate, but most of it remained on the filter, though some washed through; of the part that washed through a little was deposited in the flask as lead sulphate. Hydrogen sulphide and sulphur dioxide were not identified in any of these experiments, although in some of the filtrates there was a loss of sulphur which is not accounted for.

Each sulphide when treated alone was dissolved rather slowly, but when two were treated together the action on one of them was greatly accelerated and that on the other retarded. Sphalerite dissolved more readily in the presence of pyrite. The acid generated by the oxidation of iron was not the only factor that favored solution, for when the iron sulphide was placed on a filter above zinc sulphide the rate of solution of zinc sulphide was not greatly increased. Gottschalk and Buehler conclude that the acceleration of the reactions is due to electric currents generated by contact of minerals of different potential. The electric current flows from the mineral having the higher potential, so the one of lower potential will dissolve more rapidly, the one of higher potential being protected from oxidation and solution.

Gottschalk and Buehler arranged several minerals in a series analogous to the electromotive series of the metals, the values having been determined by the use of the Ostwald potentiometer. The results of the experiments are shown below. The force generated while any two of these minerals are immersed in a solution tends to accelerate

1 Gottschalk, V. H., and Buehler, H. A., Oxidation of sulphides: Econ. Geology, vol. 7, 1912, pp. 15-34. 
the oxidation and dissolution of that sulphide which stands lower in the series and to retard the oxidation of the one that stands higher. It is noteworthy that the experiments were made with distilled water. The potential varies with the solution, and for some salts the relations are not those indicated in the table.

Potential, in volts, of several sulphides measured in distilled water against copper wire.

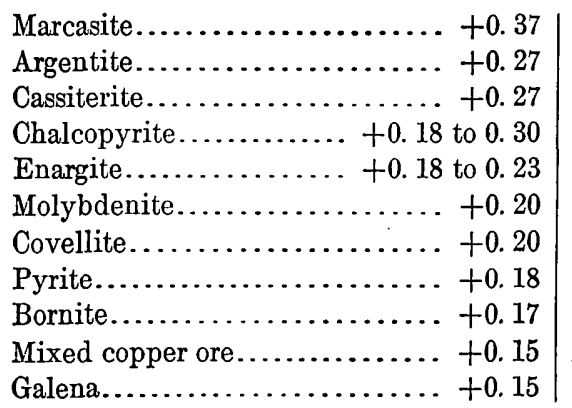

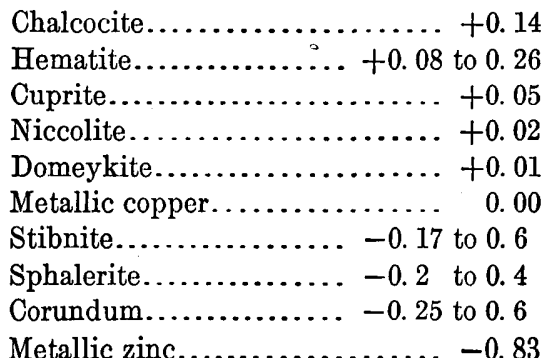

Metallic zinc................... -0.83

According to this table marcasite shows the highest electromotive force and corundum shows the lowest for the minerals, the difference being more than 0.6 volt. Metallic zinc shows a negative relation to copper of 0.83 volt, and there is a difference of 1.2 volts between the highest and lowest member of the series.

A piece of pyrite and a piece of galena, each 2 inches long and about 1 inch square, each having copper wire attached near one end, were placed in a small dish containing ordinary distilled water. The wire did not touch the water, nor were the minerals in contact. A circuit formed by placing a galvanometer between the free ends of the wires showed the same difference in potential that is shown in the above table and recorded a current of about 5 microamperes. In the course of a few days, the circuit being maintained, the galena became coated with lead sulphate, while a similar piece of galena, placed in the same solution but not in circuit, remained perfectly bright. The pyrite showed no evidence of oxidation.

Lawson ${ }^{1}$ placed a mixture of pulverized chalcocite and porphyry in a burette and passed a 10 per cent solution of ferrous sulphate through it in the presence of air. The chalcocite was dissolved and passed from the burette as copper sulphate $\left(\mathrm{CuSO}_{4}\right)$ at a fairly rapid rate.

Winchell ${ }^{2}$ placed crystals of pyrite in a sealed jar in a slightly acid solution, containing sulphur dioxide and a dilute solution of copper sulphate. At the end of three months films of chalcocite were deposited on the pyrite, and its copper content, which at the beginning

I Lawson, A. C., The copper deposits of the Robinson mining district, Nevada: Bull. Dept. Geology Univ. California, rol. 4, 1906, p. 333.

Winchell, H. V., Synthesis of chalcocite and its genesis at Butte, Mont.: Bull. Geol. Soc. America, vol. 14, 1903, pp. 272-275. 
was 1.50 , had increased to 3.60 per cent. In another jar, with similar reagents except sulphur dioxide, no chalcocite was deposited. Winchell suggests that sulphur dioxide is necessary for the deposition of cuprous sulphide. He infers that the cupric sulphate in solution with sulphur dioxide supplies cuprous ions for the reaction with the pyrite that supplies the sulphur for the chalcocite, the iron going into solution as ferrous salt. He found that iron was dissolved and subsequently precipitated as ferric hydrate.

Recently, in support of Winchell's suggestion, Spencer ${ }^{1}$ has discussed the possible reactions involved in chalcocite deposition.

The inference that cuprous ions form in this reaction has not received universal acceptance, because cuprous salts have not been identified in mine waters. Cuprous sulphate is a very unstable compound. It may be held in solution in some substances, but it is stated that when placed in water it quickly becomes cupric sulphate. Recently, however, Wells ${ }^{2}$ has shown that cuprous ions may exist in exceedingly small concentration under conditions nearly similar to those that prevail where sulphate waters attack iron and copper sulphides. Examination of eight mine waters collected by the writer failed, however, to reveal a trace of cuprous salt.

Oxygen tends to delay or to inhibit the precipitation of copper sulphides. Possibly an explanation of the behavior of the two chemical systems above described, one with and the other without sulphide dioxide, lies in the power of sulphur dioxide to remove atmospheric air from the solution. The oxygen would be removed to form sulphuric acid, and copper sulphide would then be more readily precipitated by pyrite. In the jar without sulphur dioxide enough oxygen may have been present to effectively delay precipitation.

Vogt ${ }^{3}$ pulverized 6 grams each of chalcocite, bornite, pyrrhotite, chalcopyrite, and pyrite and separately treated them in 100 cubic centimeter jars with aqueous solutions containing 30 grams of ferric chloride. After standing several years at about $14^{\circ} \mathrm{C}$. they were dissolved in the order named. The filtrates from chalcocite and bornite showed a trace of sulphate, chalcopyrite a stronger trace, and pyrite a still stronger trace. Sulphur separated from the first four minerals and probably also from pyrite. Sulphur did not appear to oxidize to sulphate in the reaction with chalcocite, though oxidation occurred in some degree with pyrite and pyrrhotite.

1 Spencer, A. C., Chalcocite deposition: Jour. Washington Acad. Sci., vol. 3, 1913, pp. 70-75.

2 Wells, R. C., Discussion of paper by F. L. Ransome on "Criteria of downward sulphide enrichment": Econ. Geology, vol.5, 1910, p. 482.

8 Vogt, J. H. L., Problems in the geology of ore deposits, in Pošepný, Franz, The genesis of ore deposits, 1802, pp. 676-677. 
In the table below the solubilities of several anhydrous sulphates are compared.

\section{Anhydrous subphate held in solution in a liter of water at $18^{\circ} \mathrm{C}$.}

[After Kohlrausch.]

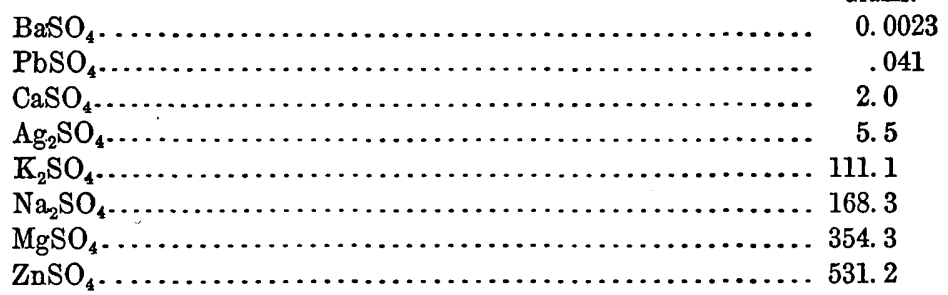

In the table below the solubilities of several hydrated sulphates are compared. ${ }^{1}$

Hydrated sulphates dissolved in a liter of water at about $20^{\circ} \mathrm{C}$.

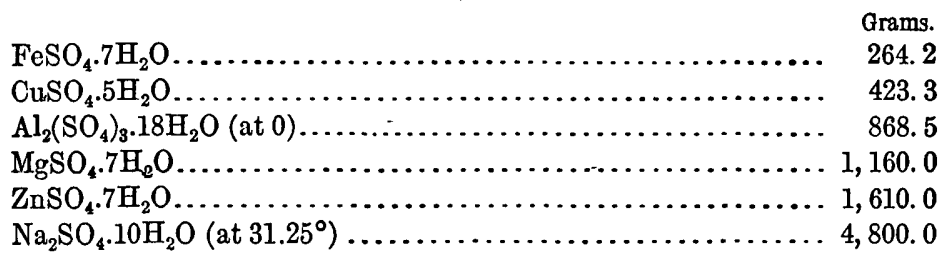

The chemical practice in the leaching process at Rio Tinto, Spain, ${ }^{2}$ is said to be as follows. The ore heaps are built up with open spaces to give ready access of air and water. In the presence of these the following reactions, according to Austin, take place:

$$
\mathrm{FeS}_{2}+.7 \mathrm{O}+\mathrm{H}_{2} \mathrm{O}=\mathrm{FeSO}_{4}+\mathrm{H}_{2} \mathrm{SO}_{4} \text {. }
$$

The ferrous sulphate oxidizes to ferric sulphate thus:

$$
2 \mathrm{FeSO}_{4}+\mathrm{H}_{2} \mathrm{SO}_{4}+\mathrm{O}=\mathrm{Fe}_{2}\left(\mathrm{SO}_{4}\right)_{3}+\mathrm{H}_{2} \mathrm{O} \text {. }
$$

The ferric sulphate reacts on chalcocite and changes it to sulphate as follows:

$$
\mathrm{Fe}_{2}\left(\mathrm{SO}_{4}\right)_{3}+\mathrm{Cu}_{2} \mathrm{~S}=\mathrm{CuSO}_{4}+2 \mathrm{FeSO}_{4}+\mathrm{CuS} \text {. }
$$

This reaction is relatively rapid, and, accordingly, about half the copper goes into solution in a few months. The covellite molecule remaining is further dissolved according to the following reaction:

$$
\mathrm{Fe}_{2}\left(\mathrm{SO}_{4}\right)_{3}+\mathrm{CuS}+3 \mathrm{O}+\mathrm{H}_{2} \mathrm{O}=\mathrm{CuSO}_{4}+2 \mathrm{FeSO}_{4}+\mathrm{H}_{2} \mathrm{SO}_{4} \text {. }
$$

This reaction is slow, but in two years, under favorable conditions, 80 per cent of the remaining half of the copper is dissolved. These chemical processes illustrate in a large way the processes of solution of chalcocite under natural conditions.

1 Data from Comey's and from Seidell's dictionaries of solubilities. I have utilized also Lindgren's compilation, Prof. Paper U. S. Geol. Survey No. 43, 1905, p. 181.

Austin, L. S., The metallurgy of the common metals, 2d ed., San Francisco, 1909, pp. 351-353. 
In connection with the processes of solution of copper at Rio Tinto, the following statement by Arthur L. Collins is of interest:

Reactions relied upon for the removal of copper from the zone of weathering, namely, the decomposition of copper sulphides by ferric sulphate, *** are employed at Rio Tinto on a very large.scale in the treatment of copper ore. The liquors from the lixiviation of heap-roasted ore were run over "raw" fine ore, originally to lessen the consumption of iron in the precipitation tanks and to secure a cleaner precipitate. But this was found to be also an efficient method of extracting part of the copper content of raw pyrites, and great heaps of mixed "raw fines" and lixiviated roasted ore, aggregating millions of tons, gradually giving up their copper in solution, largely by means of this reaction, became a feature of the Rio Tinto landscape. The supposed reaction for the reprecipitation of copper in secondary copper ores from cupric sulphate solutions by pyrites can hardly take place under these conditions; it would upset the commercial process. ${ }^{1}$

An explanation of the apparent contradiction in the theory of chalcocite enrichment is offered by S. F. Emmons. ${ }^{2}$ He notes that near the surface, where oxidation and leaching take place at Rio Tinto, the air has free access to the ore, whereas air is not admitted to ores that lie at great depths where copper is precipitated.

Copper is precipitated from sulphate solution by alkaline silicates. E. C. Sullivan ${ }^{3}$ placed finely ground materials-such as orthoclase, albite, amphibole, and clay gouge-in flasks with copper sulphate, silver sulphate, and other salts. They remained several days at room temperature, being occasionally shaken. The solutions were dilute and the precipitation in many of the flasks was nearly complete. Whether contact was maintained for a few hours or a few months made little difference. Analyses of the filtrate before and after the reactions showed that considerable material, especially the alkalies, had been dissolved from the silicate. The filtrate from 25 grams of powdered orthoclase with 40 cubic centimeters 0.1 normal sulphuric acid (2.50 millimols) gave the following results:4

Orthoclase and sulphuric acid: content of $40 \mathrm{~cm}^{3}$.

\begin{tabular}{|c|c|c|}
\hline Constituent. & Grams. & Millimols. \\
\hline 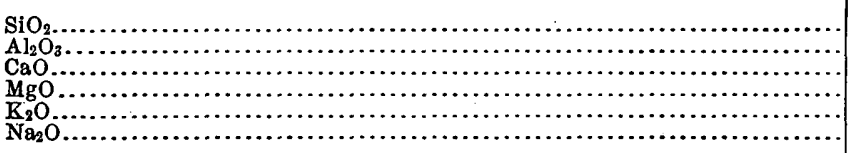 & $\begin{array}{r}0.0242 \\
.0313 \\
\text { Undet. } \\
.0010 \\
.0556 \\
.0108\end{array}$ & $\begin{array}{r}a 0.92 \\
.03 \\
.59 \\
.17\end{array}$ \\
\hline Total..................... & .1229 & 1.71 \\
\hline 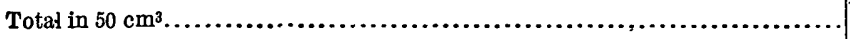 & .1536 & 2.14 \\
\hline
\end{tabular}

$a$ This is the number of divalent millimols to which 0.0313 gram alumina is equivalent.

1 Collins, A. L., in Pošepný, Franz, The genesis of ore deposits, 1902, p. 621.

2 Emmons, S. F., idem, p. 756.

${ }^{8}$ Sullivan, E. C., The interaction between minerals and water solutions, with special reference to geologic phenomena: Bull. U. S. Geol. Survey No. 312, 1907, pp. 37-64.

4 Idem, p. 50. 
The acid has dissolved somewhat less than its own equivalent of bases from the orthoclase. No change in the concentration of the sulphate radicle could be detected.

Albite $\left(\mathrm{NaAlSi}_{3} \mathrm{O}_{8}\right)$ in contact over night with cupric sulphate solution gave the following results:

Experiment with albite and cupric sulphate.

\begin{tabular}{|c|c|c|}
\hline Constituent. & Grams. & Millimols. \\
\hline 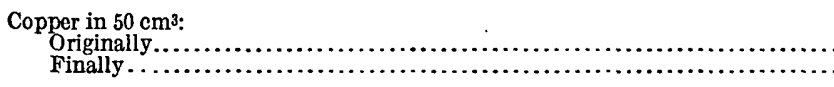 & $\begin{array}{r}0.1266 \\
.0343\end{array}$ & $\begin{array}{r}1.99 \\
.54\end{array}$ \\
\hline Loss. . . . . . . . . . ........ & .0923 & 1.45 \\
\hline 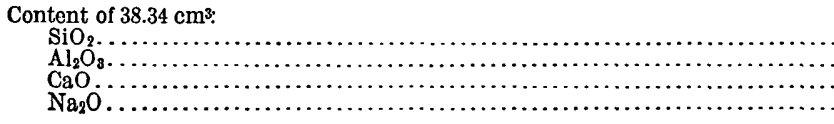 & $\begin{array}{r}.0046 \\
.0020 \\
.0107 \\
a .0516\end{array}$ & $\begin{array}{l}.06 \\
.19 \\
.83\end{array}$ \\
\hline Total......... & .0689 & 1.08 \\
\hline Content of $50 \mathrm{~cm}^{3} \ldots \ldots \ldots \ldots \ldots \ldots$ & .0898 & 1.41 \\
\hline
\end{tabular}

a Including a little $\mathrm{MgO}$ and $\mathrm{K}_{2} \mathrm{O}$.

Twenty-five grams powdered orthoclase were placed in contact for two days with 50 cubic centimeters of silver sulphate solution. The silver was almost completely precipitated.

Experiment with orthoclase and silver sulphate.

\begin{tabular}{|c|c|c|}
\hline Constituent. & Grams. & $\begin{array}{l}\text { Milli- } \\
\text { equiva- } \\
\text { lents. }\end{array}$ \\
\hline $\begin{array}{l}\text { Silver in } 50 \mathrm{~cm}^{3} \text { : } \\
\quad \text { Originally } \ldots \ldots \ldots \ldots \ldots \ldots \ldots \ldots \\
\quad \text { Finally } \ldots \ldots \ldots \ldots \ldots \ldots \ldots \ldots\end{array}$ & $\begin{array}{r}0.1066 \\
.0039\end{array}$ & $\begin{array}{r}0.98 \\
.04\end{array}$ \\
\hline Loss....... & .1027 & .94 \\
\hline 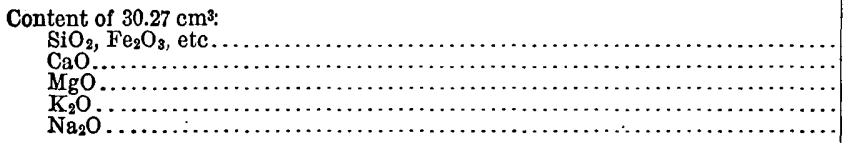 & $\begin{array}{l}.0007 \\
.0001 \\
.0004 \\
.0170 \\
.0073\end{array}$ & $\begin{array}{r}.02 \\
.36 \\
.23\end{array}$ \\
\hline Total $\ldots \ldots \ldots \ldots \ldots \ldots \ldots \ldots \ldots \ldots \ldots \ldots \ldots \ldots \ldots$ & .0255 & .61 \\
\hline Total in $50 \mathrm{~cm}^{3} \ldots \ldots \ldots \ldots \ldots . .$. & .0421 & 1.01 \\
\hline
\end{tabular}

Experiments by Sullivan on shale from Morenci, Ariz., are described by Lindgren ${ }^{1}$ as follows:

Fifty grams of shale finely ground in agate mortar were placed in 100 cubic centimeters of solution of cupric sulphate containing 0.0025 gram of copper per cubic centimeter. After standing for four days, with occasional shaking, the solution contained but 5 per cent of that amount of copper. A solution of the same strength had lost all its copper after four months' contact with shale. A concentrated solution with original content of 0.7645 gram copper per cubic centimeter had but 0.7058 gram

\footnotetext{
1 Lindgren, Waldemar, The copper deposits of the Clifton-Morenci district, Arizona: Prof. Paper U. S. Geol. Survey No. 43, 1905, p. 192.
} 
copper per cubic centimeter after a few days' contact, 100 cubic centimeters of solution thus giving up nearly 0.6 gram copper $(0.75 \mathrm{~g}$. cupric oxide, $\mathrm{CuO})$ to 50 grams shale.

A certain amount of acid radicle is also taken from the solution by the shale. This loss in one experiment with the dilute copper sulphate mentioned was something over 10 per cent of the total $\mathrm{SO}_{4}$.

The shale in turn gives off a part of its constituents to the solution, about 0.2 gram having been found in 100 cubic centimeters after treatment with the dilute coppersulphate solution. This is 0.4 per cent of the 50 grams shale taken. Of this dissolved matter, mostly present as sulphate, one-third to one-half was potassium oxide, most of the remainder being magnesium oxide and calcium oxide, with sodium oxide, manganese oxide, ferric oxide, and silica in smaller quantities.

The acidity of the solution was not increased by removal of copper, analysis showing that copper precipitated in excess of that equivalent to the acid radicle removed was replaced in solution by other bases as sulphates.

Reactions of this character are probably at some places important processes in the enrichment of ore bodies, for the essential conditions of the experiments commonly exist in nature. The neutralization of the acid solutions by the alkaline silicates permits also such reactions as are favored by a neutral environment.

In some silver and copper mines clay gouge and highly altered material carry valuable minerals. This altered material may have been produced by the attrition of rock originally metalliferous, but the experiments described above suggest processes by which it may have been enriched. The results of experiments showing the extent to which these reactions may go on when sulphides also are present are not available.

According to Stephen H. Emmens, ${ }^{1}$ hydrogen sulp?': de and sulphur dioxide form with sulphur as intermediate steps in the oxidation of pyrite. These compounds, however, will oxidize where oxygen is in excess, or in the absence of water pressure they can readily escape; thus hydrogen sulphide would have but little effect in precipitating the metals in the oxidizing zone.

The statement of Emmens that hydrogen sulphide is formed in the oxidation of sulphides was made as early as 1892 , but it was not supported by a record of experiments and it has not received the attention that it probably deserves. Buehler and Gottschalk showed that pure water does not generate hydrogen sulphide in the presence of oxygen with sulphides, but it is formed on contact with some sulphides and weak sulphuric acid.

The crystallized and the freshly precipitated sulphides of a metal may show considerable difference in solubility in water, as is indicated by the table below, which gives the results of a number of determinations by Weigel, ${ }^{2}$ who used a sensitive apparatus for measuring these very low solubilities. Weigel showed also that the amount

1 Emmens, S. H., The chemistry of gossan: Eng. and Min. Jour., vol. 54, 1892, pp. 582-583.

2 Welgel, Oskar, Die Löslichkeit von Schwermetallsulfiden in reinem Wasser: Zeitschr. phys. Chemie, rol. 58, 1907, pp. 293-300. 
of lead sulphide dissolved in water increases for a short period and then decreases, owing probably to the precipitation from the solution of crystallized galena, or some dense form which is less soluble than the freshly precipitated sulphide.

Solubility of the sulphides of the heavy metals in distilled water at $18^{\circ} \mathrm{C}$.

[Mols $\times 10^{-6}$ per liter.]

\begin{tabular}{|c|c|c|c|}
\hline \multicolumn{2}{|l|}{ Crystallized. } & \multicolumn{2}{|c|}{ Freshly precipitated (probably amorphous). } \\
\hline MnS. $\ldots \ldots \ldots \ldots \ldots \ldots \ldots \ldots$ & 54.5 & MnS. $\ldots \ldots \ldots \ldots \ldots \ldots \ldots \ldots \ldots$ & 71.60 \\
\hline Pyrrhotite................... & 53.6 & ZnS.. & 70.60 \\
\hline Pyrite (Freiberg) . . ........... & 48.89 & 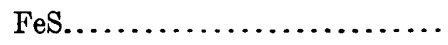 & 70.1 \\
\hline Pyrite (artificial)............. & 40.84 & 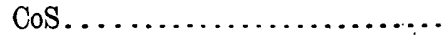 & 41.62 \\
\hline Wurtzite (artificial) . .......... & 28.82 & NiS. . & 39.87 \\
\hline Millerite (artificial)) $\ldots \ldots \ldots \ldots$ & 16. 29 & $\ldots \ldots \ldots \ldots \ldots \ldots \ldots$ & 9.00 \\
\hline Greenockite (artificial).... & 8.99 & $\mathrm{Sb}_{2} \mathrm{~S}_{3}$ & 5.2 \\
\hline Zinc blende (Santander) . ........ & 6.55 & $\mathrm{PbS}$. & 3.6 \\
\hline Zinc blende (artificial) . ........ & 6.63 & 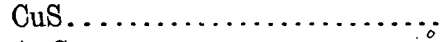 & 3.51 \\
\hline $\mathrm{Cu}_{2} \mathrm{~S} . \ldots \ldots \ldots \ldots \ldots$ & 3.1 & $\mathrm{As}_{2} \mathrm{~S}_{3} \ldots \ldots \ldots \ldots \ldots \ldots \ldots \ldots$ & 2.1 \\
\hline Galena (Freiberg) ............ & 1. 21 & $\mathrm{Ag}_{2} \mathrm{~S}, \ldots \ldots \ldots \ldots \ldots \ldots \ldots \ldots \ldots$ & .552 \\
\hline Galena (artificial) .............. & 1. 21 & $\mathrm{Bi}_{2} \mathrm{~S}_{3} \ldots \ldots \ldots \ldots \ldots \ldots \ldots \ldots \ldots$ & .35 \\
\hline Galena (from precipitated $\mathrm{PbS}$ ). & 1.18 & HgS. . . . . . . . . . . . . . . & .054 \\
\hline $\mathrm{SnS}_{2} \ldots \ldots \ldots \ldots \ldots \ldots \ldots \ldots$ & 1.13 & & \\
\hline $\mathrm{Ag}_{2} \mathrm{~S} \ldots \ldots \ldots \ldots \ldots \ldots \ldots \ldots$ & .5522 & & \\
\hline SnS (crystallized) . . . . . . . . . & .14 & & \\
\hline
\end{tabular}

Schuermann, ${ }^{1}$ after extensive experimentation, established a series in which the sulphides of any one of the metals thereof will be precipitated at the expense of any sulphide lower in the series. $\mathrm{He}$ used 50 cubic centimeters, of about 0.1 formula weight, of solutions of the salts noted below with 100 cubic centimeters of water and introduced small amounts of metallic sulphides.

Amounts of various salts used in Schuermann's experiments.

\begin{tabular}{|c|c|}
\hline \\
\hline \\
\hline & \\
\hline 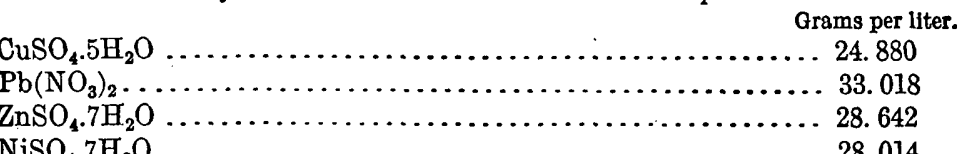 & \\
\hline \multirow{2}{*}{\multicolumn{2}{|c|}{$\begin{array}{l}\mathrm{Co}\left(\mathrm{NO}_{3}\right)_{2} \cdot 6 \mathrm{H}_{2} \mathrm{O} \ldots . \\
\mathrm{FeSO}_{4} \cdot 7 \mathrm{H}_{2} \mathrm{O} \ldots \ldots\end{array}$}} \\
\hline \multirow{2}{*}{\multicolumn{2}{|c|}{$\begin{array}{l}\mathrm{FeSO}_{4} \cdot 7 \mathrm{H}_{2} \mathrm{O} \\
\mathrm{HgCl}_{2} \ldots \ldots \ldots\end{array}$}} \\
\hline & \\
\hline \multicolumn{2}{|l|}{$\mathrm{CdSO}_{4} \cdot \frac{8}{3} \mathrm{H}_{2} \mathrm{O}$} \\
\hline \multirow{2}{*}{\multicolumn{2}{|c|}{$\begin{array}{l}\mathrm{BiO}_{2} \cdot \mathrm{H}_{2}\left(\mathrm{NO}_{3}\right) \\
\mathrm{MnSO}_{4} \cdot 5 \mathrm{H}_{2} \mathrm{O} .\end{array}$}} \\
\hline & \\
\hline \\
\hline \multicolumn{2}{|c|}{ 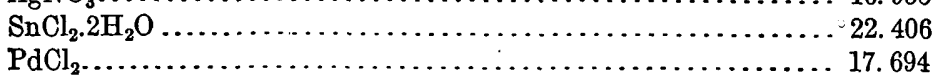 } \\
\hline \multirow{2}{*}{\multicolumn{2}{|c|}{ 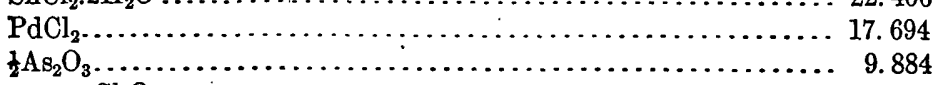 }} \\
\hline & 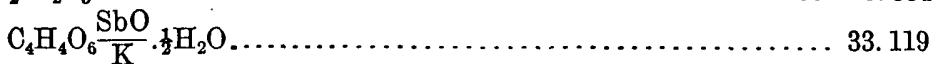 \\
\hline
\end{tabular}

The sulphides were placed in 150 cubic centimeter flasks that were closed with a Bunsen valve to allow steam to escape and to prevent access of air. On the application of heat the metal in solution as

\footnotetext{
1 Schuermann, Ernst, Ueber die Verwandtschaft der Schwermetalle zum Schwefel: Liebig's Ann. der Chemie, vol. 249, 1888, p. 326.
} 
sulphate, as chloride, or as nitrate was precipitated as sulphide, and the metal of the introduced sulphide simultaneously went into solution. In general, the attack was continued for several hours. His series is as follows: Palladium, quicksilver, silver, copper, bismuth, cadmium, lead, zinc, nickel, cobalt, iron, thallium, and manganese. Under the conditions named any metal in solution will, according to Schuermann, be precipitated as sulphide if in contact with a metal lower in the series and the metal lower in the series wili simultaneously go into solution. As a rule the reaction is the more nearly complete the farther apart the two metals are in the series.

In a series which he regards as showing the "relative affinity" of the heavy metals for sulphur Schuermann includes antimony, arsenic, and tin. This series is palladium, mercury, silver, copper, bismuth, cadmium, antimony, tin, lead, zinc, nickel, cobalt, iron, arsenic, thallium, and manganese. Those last named have the least affinity.

Schuermann's results have been widely applied. The term "chemical affinity" is a convenient one but is used in absence of more definite information to express a relation, not chemical constants. As pointed out by Wells, the principal results of Schuermann's experiments may be regarded as reactions establishing chemical equilibria, the salts being fixed in order of their solubilities under the conditions of the experiments. The positions of the commoner metals in the Schuermann series agree fairly well with the solubilities of the sulphides determined by Weigel, and the metals which replace those lower in the series generally have lower solubilities than those which are replaced. As shown in the table that follows there are, however, several discrepancies between the Schuermann series and Weigel's table.

If ammonium sulphide is added to a solution in which the metals are dissolved (in equal molar concentration) those which have the lowest solubilities should be precipitated first. Under similar conditions and with equal molar concentrations the metals would be precipitated by ammonium sulphide approximately but not exactly in the order indicated in the Schuermann series. This order of precipitation would hold, however, for the sulphides of the most common metals and for those which are assumed to be most important in problems of sulphide enrichment.

In the table below Schuermann's series is compared with a series showing the solubilities of the metallic sulphides as determined by Weigel, the numbers in parentheses indicating the order of (molar) solubility. In Schuermann's series the metals are arranged in the order of their decrease of "affinity for sulphur." 1 In Weigel's series the order of solubility of the freshly precipitated metallic sul-

\footnotetext{
1 Schuermann, Ernst, Ueber die Verwandstchaft der Schwermetalle zum Schwefel: Liebig's Ann. der Chemie, vol. 249, 1888, p. 326. Emmons, S. F., The secondary enrichment of ore deposits: Trans. Am. Inst. Min. Eng., vol. 30, 1901, p. 212. Weed, W. H., The enrichment of gold and silver veins: Trans. Am. Inst. Min. Eng., vol. 30, 1901, p. 428; The affinity of metals for sulphur: Eng. and Min. Jour., vol. 50. 1890, p. 484; Review of lecture by Watson Smith, on Schuermann's reactions: Jour. Soc. Chem. Ind., vol. 11, 1892, pp. 869-871.
} 
phides is expressed in mols per liter $;^{1}$ to each amount stated should be applied the factor $\times 10^{-8}$.

Comparison of Schuermann's and Weigel's series.

Schuermann's ser
(1) $\mathrm{Hg}$.
(2) $\mathrm{Ag}$.
(3) $\mathrm{Cu}$.
(4) $\mathrm{Bi}$.
(5) $\mathrm{Cd}$.
(6) $\mathrm{Pb}$.
(7) $\mathrm{Zn}$.
(8) $\mathrm{Ni}$.
(9) $\mathrm{Co}$.
(10) $\mathrm{Fe}$.
(11) $\mathrm{Mn}$.

Weigel's series.

(1) $\mathrm{HgS} \ldots \ldots \ldots \ldots \ldots \ldots \ldots \ldots \ldots \ldots \ldots, 0.054$

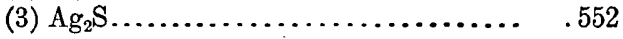

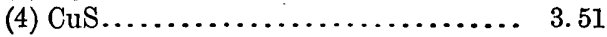

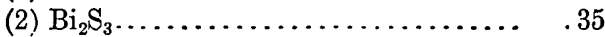

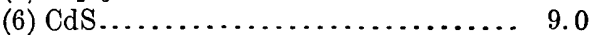

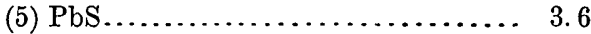

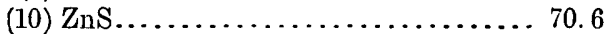

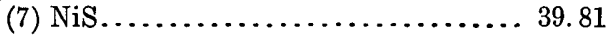

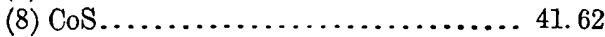

(9) FeS.......................... 70.1

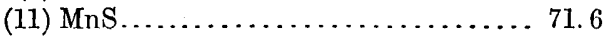

Hydrogen sulphide is made in the chemical laboratory by treating artificial ferrous sulphide with acid. The generation of hydrogen sulphide is almost instantaneous. As recently shown by Allen, pyrrhotite is in reality a solid solution of ferrous sulphide (FeS) and sulphur. Both pyrrhotite and zinc blende dissolve in acid with noticeable evolution of hydrogen sulphide, whereas pyrite and chalcopyrite are almost insoluble in sulphuric or in hydrochloric acid. They are readily decomposed, however, in nitric, an oxidizing acid.

Several experiments were made by R. C. Wells to ascertain the rates at which hydrogen sulphide is generated by the action of cold dilute acid waters on sulphides of the metals. The ores, obtained from the Smithsonian Institution through the courtesy of Dr. J. E. Pogue, were pyrite from Leadville, Colo.; chalcopyrite from the Cactus mine, Utah; sphalerite from Webb City, Mo.; pyrrhotite from Ely, Vt.; and galena from the Motley mine, Carterville, Mo. All these specimens appeared to be pure. They were powdered, washed with hydrochloric acid, alcohol, and ether, and sifted, the material passing a 200-mesh sieve and that held on an 80-mesh sieve being rejected. Thus the material used was free from fine dust and lumps.

In preliminary experiments the minerals were used in quantities proportional to their densities, thus insuring approximately equal surfaces. Portions of the minerals placed in flasks and covered with 0.1 normal sulphuric acid showed no visible change until a week had elapsed, when flasks containing pyrrhotite began to show a precipitate of basic ferric sulphate. No regularity was found in the variation in the acidity of the solutions on account of the simultaneous consumption and production of acid with the different minerals.

The five minerals were further exposed overnight to $0.057 \mathrm{normal} \mathrm{sul-}$ phuric acid. The resulting solutions were titrated with iodine solution to ascertain the amount of hydrogen sulphide generated, the iodine solution used being, for pyrrhotite, 28.5 cubic centimeters; for sphalerite, 1.05 cubic centimeters; for galena, 0.40 cubic centimeter; for chalcopyrite, 0.29 cubic centimeter; for pyrite, 0.28 cubic centimeter. 
A set of experiments exactly similar to the above was made, the resulting solutions being titrated with potassium permanganate. The consumption of the salt with the solutions from pyrrhotite greatly exceeded the consumption with those from any other mineral.

In another series of experiments the hydrogen sulphide generated by the action of cold dilute acid on pyrrhotite, on sphalerite, and on galena was determined qualitatively by lead acetate paper. There was no proof that hydrogen sulphide was formed with either pyrite or chalcopyrite, and the very small quantities indicated above $(0.28$ cubic centimeter for pyrite and 0.29 cubic centimeter for chalcopyrite) are not regarded by $\mathrm{Mr}$. Wells as proof that hydrogen sulphide is formed by the action of acid on pyrite and chalcopyrite. The slight reduction of the iodine solution may represent a correction for the end point of the titration.

\section{COMPOSITION OF MINE WATERS.}

\section{ANALYSES.}

The following tables show the results of analyses of 37 samples of water taken from mines containing deposits of sulphide ore:

Analyses of mine waters.

Waters of copper mines.

[Parts per million.]

\begin{tabular}{|c|c|c|c|c|c|c|c|c|c|}
\hline & 1 & 2 & 3 & 4 & 5 & 6 & 7 & 8 & 9 \\
\hline \multirow{4}{*}{$\begin{array}{l}\mathrm{SO}_{4} \ldots \ldots \ldots \\
\mathrm{Cl} \ldots \ldots \ldots \\
\mathrm{CO}_{8} \ldots \ldots \ldots \\
\mathrm{PO}_{4} \ldots \ldots \ldots \\
\mathrm{B}_{4} \mathrm{O}_{7} \ldots \ldots \\
\mathrm{Br} \ldots \ldots \ldots\end{array}$} & \multirow{3}{*}{$\begin{array}{r}406.5 \\
6.8 \\
13.2 \\
\text { Tr. } \\
\ldots . . .\end{array}$} & \multirow{3}{*}{$\begin{array}{r}544.7 \\
118.5 \\
\text { Tr. } \\
\text { Tr. } \\
\ldots\end{array}$} & $\begin{array}{l}90.6 \\
11.8\end{array}$ & $\begin{array}{l}593.4 \\
842.8\end{array}$ & $\begin{array}{r}71,053.3 \\
17.7\end{array}$ & $\begin{array}{r}2,672.0 \\
13.0\end{array}$ & $\begin{array}{r}492.1 \\
95.7\end{array}$ & $\begin{array}{r}6,664.0 \\
.1\end{array}$ & $\begin{array}{r}2,068.0 \\
2.2\end{array}$ \\
\hline & & & $\dddot{\mathrm{T}} \mathrm{r}$. & Tr. & 1.5 & Tr. & & & …........ \\
\hline & & & ….. & $\cdots \cdots$ & ……........ & $\begin{array}{l}\text { Tr. } \\
\text { Tr. }\end{array}$ & & .......... & …........ \\
\hline & & 272 & 361 & 295 & 674 & $\mathrm{Tr}_{7}$ & & & \\
\hline & $\begin{array}{r}2.2 \\
7.1 \\
16.2\end{array}$ & $\begin{array}{r}27.2 \\
30.5 \\
176.9\end{array}$ & $\begin{array}{r}0.1 \\
3.5 \\
11.1\end{array}$ & $\begin{array}{l}29.5 \\
11.4 \\
82.8\end{array}$ & $\begin{array}{r}6.4 \\
61.7 \\
41.7\end{array}$ & $\begin{array}{l}4 . .1 \\
13.1 \\
39.6\end{array}$ & $\begin{array}{l}94.8 \\
27.9 \\
33.0\end{array}$ & $\begin{array}{l}55.6 \\
19.8 \\
23.4\end{array}$ & $\begin{array}{r}78.9 \\
7.8 \\
5.9\end{array}$ \\
\hline $\begin{array}{l}\text { Li.. } \\
\text { Ca.. }\end{array}$ & $\begin{array}{r}\text { Tr. } \\
151.2\end{array}$ & 92.7 & 49.0 & 512.1 & $\begin{array}{r}T r \\
307.7\end{array}$ & 132.5 & 105.8 & 67.6 & 2380 \\
\hline $\mathrm{Mg}$. & 28.2 & 17.9 & 10.3 & 102.6 & 149.2 & 61.6 & 25.5 & 40.6 & 63.3 \\
\hline Al.......... & 0.0 & & & & 85.2 & 83.5 & & 433.0 & 165.0 \\
\hline$\frac{\mathrm{Mn}}{\mathrm{Ni}} \ldots \ldots \ldots$ & .5 & Tr. & 2.5 & 1.4 & $\begin{array}{r}13.2 \\
3.5\end{array}$ & 12.0 & ...... & .2 & .3 \\
\hline & & & & & $\begin{array}{l}5.0 \\
4.6\end{array}$ & .5 & & & \\
\hline & $\mathrm{Tr}$. & .4 & & & $45,633.2$ & 59.1 & ... & 312.1 & $\ddot{40 . \ddot{8}}$ \\
\hline $\begin{array}{l}\text { Zn... } \\
\text { Cd... }\end{array}$ & .3 & 1.8 & 1.9 & 0.0 & 411.2 & $\begin{array}{r}852.0 \\
41.1\end{array}$ & .. & 199.8 & 54.3 \\
\hline $\mathrm{Fe}^{\prime \prime}$ & 1.8 & 1.4 & .9 & .4 & 49.8 & 159.8 & 58.1 & $2,178.0$ & 1.3 \\
\hline & & & & & & & & & 186.3 \\
\hline $\mathrm{H}_{2} \mathrm{SO}_{4} \ldots$ & Alk. & Alk. & Alk. & Alk. & & & & 129.6 & 406.5 \\
\hline
\end{tabular}

1. Green Mountain mine, Butte, Mont., 2,200-foot level in fissure in "granite," remote from known veins. Crosscut opened day before sample was taken. W. F. Hillebrand, analyst.' Weed, W. H., Geology and ore deposits of the Butte district, Montana: Prof. Paper U. S. Geol. Survey No. 74, 1912, p. 101.

2. Glengarry mine, Butte, Mont., 220-foot crosscut south. Very slightly alkaline. Black deposit containing FeS, much free sulphur, and probably $\mathrm{ZnS}$. W. F. Hillebrand, analyst. Weed, idem.

3. Anaconda mine, Butte, Mont., 800 feet west. Very faintly alkaline; deposits iron and manganese. W. F. Hillebrand, analyst. Weed, Idem.

i. Gagnon mine, Butte, Mont. 1,125 feet from shaft. Very faintly alkaline; deposits iron. Weed, idem.

5. Mountsin View mine, Butte, Mont., second level. W. F. Hillebrand, analyst. Clarke, F. W., The date of geochemistry: Bull. U. S. Geol. Survey No. 330, 1908, p. 546; also Weed, loc. cit.

6. St. Lawrence mine, Butte, Mont. W. F. Hillebrand, analyst. Clarke, loc. cit.; also Weed, loc. cit. 7. Rath mine, Robinson mining district, Nevada, bottom of inclined shaft. $\mathbf{H}$. $E$. ' Miller, analyst. Lawson, A. C., The copper deposits of the Robinson mining district, Nevada: Bull. Dept. Geology Univ. Californis, vol. 4, 1906, p. 332 .

8. Burra Burra mine, Ducktown, Tenn., first level below black copper workings. R. C. Wells, analyst. Emmons, W. H., and Laney, F. B., Preliminary report on the mineral deposits of Ducktown, Tenn.: Bull. U.'s. Geol.' Survey No. 470, 1911, pp. 171-172.

9. East Tennesseo mine, Ducktown, Tenn., 30-foot fathom level. R. C. Wells, analyst. Emmons and Laney, idem. 
Analyses of mine waters-Continued.

Waters of copper mines-Continued.

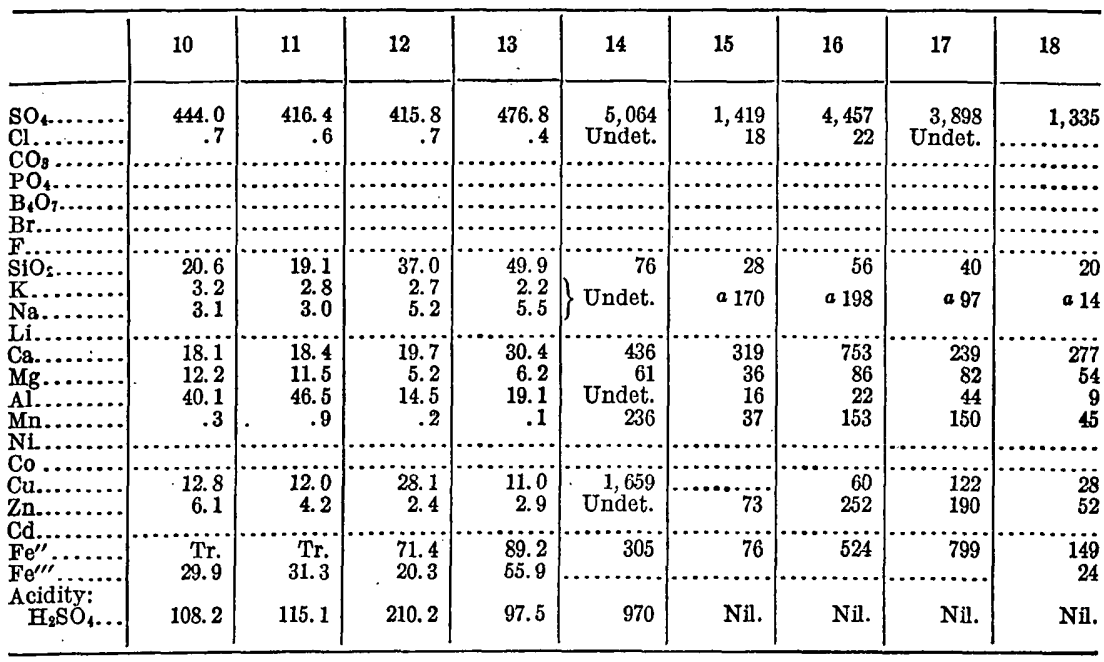

a Calculated as $\mathrm{K}_{2} \mathrm{O}+\mathrm{Na}_{2} \mathrm{O}$.

10. No. 20 shaft (top), Ducktown, Tenn. Emmons and Laney, unpublished manuscript.

11. No. 20 shaft (bottom), Ducktown, Tenn. Emmons and Laney, fdem.

12. Callaway shaft, Ducktown, Tenn., at water level. R. C. Wells, analyst. Emmons and Laney, Preliminary report on the mineral deposits of Ducktown, Tenn.: Bull. U. S. Geol. Survey No. 470, 1911, pp. 171-172.

13. Callaway shaft, Ducktown, Tenn., 37 feet below water level. R. C. Wells, analyst. Emmons and

Laney, idem.
14. Capote mine, Cananea, Mexico, 300-foot level. G. W. Hawley (chief chemist Cananea Consolidated Copper Company), analyst. Analyses 14 to 17 obtained through the courtesy of Mr. D. P. Hynes.

15. Capote mine, Cananea, Mexico, 400-foot level. G. W. Hawley, analyst.

16. Capote mine, Cananea, Mexico, 900-foot level. G. W. Hewley, analyst.

17. Capote mine, Cananea, Mexico, water pumped from mine. G. W. Hawley, analyst.

18. Capote, Puertacitas, Cananea-Duluth, and Democratic mines, Cananea, Mexico, water used at concentrator at Cananea. Circulates at concentrator in contact with ore and air. G. W. Hawley, analyst. 
Analyses of mine waters-Continued.

Waters of gold, sllver, and gold and sllver mines.

\begin{tabular}{|c|c|c|c|c|c|c|c|c|c|c|}
\hline & 19 & 20 & 21 & 22 & 23 & 24 & 25 & 26 & 27 & 28 \\
\hline 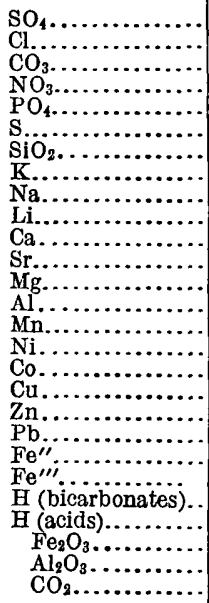 & \begin{tabular}{r}
43.20 \\
7.90 \\
110.50 \\
$\ldots \ldots .$. \\
$\mathrm{Tr}$. \\
\hdashline 25.90 \\
10.60 \\
36.40 \\
$\mathrm{Tr}$. \\
37.40 \\
13.25 \\
12.25 \\
.40 \\
.80
\end{tabular} & 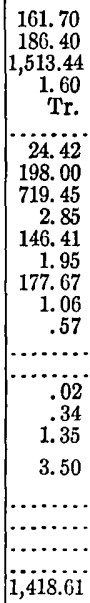 & 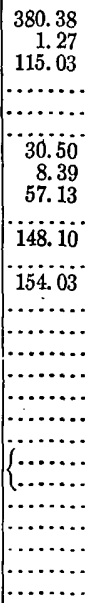 & $\begin{array}{r}\ldots \ldots \\
133.40 \\
53.40 \\
132.00 \\
\cdots \ldots 0.10 \\
\cdots \\
\ldots .88 \\
1.37 \\
\ldots \ldots \ldots \\
\ldots \ldots \ldots \\
\ldots \ldots \ldots\end{array}$ & 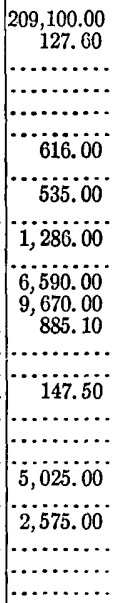 & $\begin{array}{r}37.86 \\
62.26 \\
.27 \\
772.37\end{array}$ & $\begin{array}{r}89.96 \\
6.86 \\
133.70\end{array}$ & $\mid \begin{array}{r}\cdots \\
68.92 \\
254.10 \\
7.84 \\
\cdots \ldots . . \\
84.08\end{array}$ & 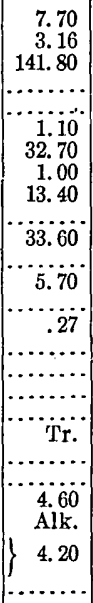 & 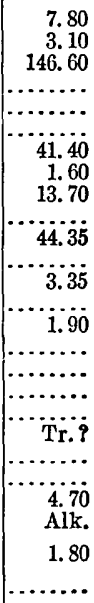 \\
\hline
\end{tabular}

19. Geyser mine, Custer County, Colo., 500-foot level. W. F. Hillebrand, analyst. Emmons, S. F., The mines of Custer County, Colo.: Seventeenth Ann. Rept. U. S. Geol. Survey, pt. 2, 1896, p. 461.

20. Geyser mine, Custer County, Colo., 2,000-foot level. W. F. Hillebrand, analyst. Emmons, S. F., op. cit., p. 462 .

21. Savage mine (Comstock lode), Storey County, Nev., 600-foot level.

22. C. \& C. shaft (Comstock lode), Storey County, Nev., 2,250-foot level. N. E. Wilson, analyst. Reid, J. A., The structure and genesis of the Comstock lode: Bull. Dept. Geology Univ. California, vol. 4, 1906, p. 189.

23. Central tunnel (Comstock lode), Storey County, Nev., vadose water. N. E. Wilson, analyst. Reid, J. A., loc. cit., p. 192 .

24. Gould \& Curry mine (Comstock lode), Storey County, Nev., 1,700-foot level.

25. Hale \& Norcross tunnel section (Comstock lode), Storey County, Nev.

26. Gould \& Curry mine (Comstock lode), Storey County, Nev., 1,800-foot level.

27. Federal Loan mine, Nevada City, Cal., 400-foot level. 'W. F. Hillebrand, analyst. Lindgren, Waldemar, The gold-quartz veins of Nevada City and Grass Valley, California: Seventeenth Ann. Rept. U. S.

Geol. Survey, pt. 2, 1896, p. 121. 
Analyses of mine waters-Continued.

Waters of gold, silver, and gold and sllver mines-Continued.

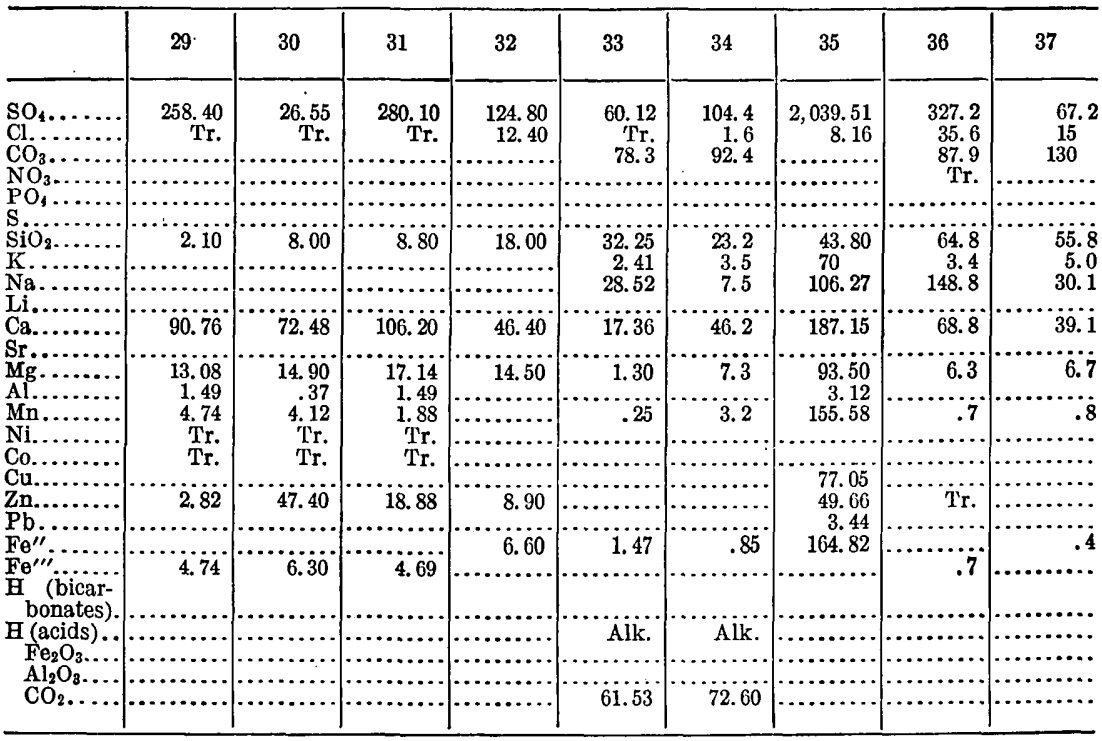

29-32. Rothschönberger Stolln, Freiberg, Germany. A. Frenzel, analyst. Beck, Richard, The nature of ore deposits (translated by W. H. Weed), vol. 2,1905, p. 377.

33. Bachelor mine, Creede, Colo. Iron includes some aluminum. Water is alkaline. Chase Palmer, analyst.

34. Solomon mine, Creede, Colo. Iron includes some aluminum. Water is alkaline. Chase Palmer, analyst.

35. Stanley mine, Idaho Springs, Colo. L. J. W. Jones, analyst. Jones, L. J. W., Ferric sulphate in mine waters and its action on metals: Proc. Colorado Sci. Soc., vol. 6, 1897-1900, p. 48.'

36. Mizpah mine, Tonopah, Nev., from bore hole 2,316 feet deep. Bicarbonates were reduced to normal carbonates. R. C. Wells, analyst.

37. Nettie mine, Butte, Mont., 300-foot level. W. F. Hillebrand, analyst. Weed, W. H., Geology and ore deposits of the Butte district, Montana: Prof. Paper U. S. Geol. Survey No. 74, 1912, p. 101.

\section{DISCUSSION OF ANALYSES.}

\section{MINES REPRESENTED.}

Of the foregoing analyses of 37 samples of water taken from mines containing sulphide deposits, samples 1 to 18 were taken from copper mines and samples 19 to 37 from gold, silver, and gold-silver mines. The tables include almost all the available nearly complete analyses of waters from sulphide deposits in noncalcareous rocks. Among those not included in the table are several analyses of waters from the district in southeastern Missouri containing disseminated lead deposits, discussed by Buckley, ${ }^{1}$ and some analyses of waters from the Granby district and from Joplin, in southwestern Missouri. A number of partial analyses of waters from gold mines of Australia and New Zealand are reported by Don, ${ }^{2}$ and several analyses of

\footnotetext{
1 Buckley, E. R., Geology of the disseminated lead deposits of St. Francois and Washington counties: Missouri Bur. Geology and Mines, vol. 9, pt. 1, 1908, pp. 99, 171, 249.

2 Don, J. R., The genesis of certain auriferous lodes: Trans. Am. Inst. Min. Eng., vol. 271898 p. 654.
} 
waters of the Homestake mine, Lead, S. Dak., have recently been published by Sharwood. ${ }^{1}$ Analyses of waters from the Lake Superior copper mines, reported by Lane, ${ }^{2}$ have not been included in the tables, for these are chloride waters and their discussion would be irrelevant to the subject of sulphide enrichment.

Five mines are represented by two or more analyses. More extended series of analyses of waters taken at different depths from the same body of water would be very useful in investigations made to determine the acidity and the state of oxidation of waters as related to depth. The first work of this character was done by Lepsius, ${ }^{3}$ who showed that the oxygen content of waters taken from bore holes decreases with increase of depth. A series of samples (Nos. 14 to 17) from the different levels of the Capote mine, Cananea, Sonora, analyzed under the direction of G. W. Hawley, chief chemist of the Cananea Consolidated Copper Co., is especially valuable. Samples 12 and 13 were obtained from the Callaway shaft at Ducktown, Tenn.; sample 12 was taken from the top of the water level in this shaft, and sample 13 was taken 37 feet below. To obtain this sample a special device was arranged by Mr. Laney and myself for subaqueous filtration. This device consisted of a crate holding two 1-gallon bottles, below which was attached a heavy weight to sink the unfilled bottles; below this was attached, with a short rope, a second weight for sounding. Each bottle was equipped with a small cylindrical filter tube charged with asbestos wool. A perforated porcelain disk was placed below and another above the wool to equalize pressure. The filter tube extended nearly to the bottom of the bottle to prevent air from coming into contact with the water dropping into the bottles: Each stopper was fitted with a glass exhaust tube extending from the top of the bottle to a point above the filter, and the upper end of each tube was fitted with a valve which let out air but prevented any intake of water. Rubber sheeting was fastened over the filter to prevent premature entry of waters and this was removed by means of a strong cord passed to the surface. The bottles were lowered slowly to prevent the stirring of the water in the shaft.

Many of the samples were taken from small bodies of water standing in mines. The water in such bodies is generally more concentrated than the average water of the mines and is probably not typical underground mine water. Samples 8, 9, 10, 11, 12, 13, 22, 27, 28,

\footnotetext{
1 Sharwood, W. J., Analyses of some rocks and minerals from the Homestake mine, Lead, S. Dak.: Econ. Geology, vol. 6, 1911, p. 742.

2 Lane, A. C., Mine waters: Proc. Lake Superior Min. Inst., vol. 13, 1908, pp. 63-152; Michigan iron mines and their mine waters: Jour. Canadian Min. Inst., vol. 12, 1910, p. 124.

- Lepsius, B., Ueber die Abnahme de gelösten Sauerstoffs in Grundwasser und einen einfachen Apparat zur Entnahme von Tiefproben in Bohrlochern: Ber. Deutsch. chem. Gesell., vol. 18, pt. 2, 1885, pp. 24872490.
} 
$33,34,36$, and probably several others were taken from underground streams or rills or from large bodies of standing water.

The composition of mine water, especially that in the upper part of a deposit, is changed by the opening of the mine, by which, doubtless, the water is more highly oxidized and probably its acidity is increased. The addition of artificial water channels and the depression of the ground-water level by pumping produces mixtures of water from several levels and increases the rate of the underground circulation. This increase tends to dilute the waters; but, on the other hand, the downward change to a more highly oxidized and therefore a more highly acid condition will render the solutions more active solvents and tend to increase the concentration of metals they contain. Which set of processes predominates can not be shown, but the analyses represent only qualitatively the character of the solutions by which alterations of sulphide ores are brought about. Many of the analyses are not complete, and some analysts do not state whether certain elements were looked for. Some of the averages are therefore only rude approximations.

In the work of recalculating these analyses to the ionic form of statement I have had assistance from Messrs. H. K. Shearer, N. Sankowsky, and Clarence Russell.

\section{CHEMICAL CHANGES INDICATED.}

Sulphates and sulphuric acid.-Sulphides exposed to air and water are changed to sulphates and to sulphuric acid. The iron minerals are the more important sources of sulphuric acid because some of them contain more sulphur than that necessary to balance iron when iron sulphate forms and because iron sulphate in the presence of oxygen forms the ferric salt, which hydrolyzes readily, giving basic ferric sulphate and ultimately limonite. Galena and zinc blende may oxidize to sulphates without liberating acid. The following equations, which represent certain stages in the reactions, illustrate this principle:

$$
\begin{aligned}
& \mathrm{FeS}_{2}+\mathrm{H}_{2} \mathrm{O}+7 \mathrm{O}=\mathrm{FeSO}_{4}+\mathrm{H}_{2} \mathrm{SO}_{4} \cdot \\
& \mathrm{Fe}_{7} \mathrm{~S}_{8}+\mathrm{H}_{2} \mathrm{O}+31 \mathrm{O}=7 \mathrm{FeSO}_{4}+\mathrm{H}_{2} \mathrm{SO}_{4} \cdot \\
& \mathrm{CuFeS}+8 \mathrm{O}=\mathrm{FeSO}_{4}+\mathrm{CuSO}_{4} \cdot \\
& \mathrm{PbS}+4 \mathrm{O}=\mathrm{PbSO}_{4} \cdot \\
& \mathrm{ZnS}+4 \mathrm{O}=\mathrm{ZnSO}_{4} .
\end{aligned}
$$

The oxidation of ferrous sulphate to ferric salt and the hydrolyzation of ferric sulphate take place very readily in the presence of oxygen.

$$
\begin{gathered}
2 \mathrm{FeSO}_{4}+\mathrm{H}_{2} \mathrm{SO}_{4}+\mathrm{O}=\mathrm{Fe}_{2}\left(\mathrm{SO}_{4}\right)_{3}+\mathrm{H}_{2} \mathrm{O} . \\
6 \mathrm{FeSO}_{4}+3 \mathrm{O}+3 \mathrm{H}_{2} \mathrm{O}=2 \mathrm{Fe}_{2}\left(\mathrm{SO}_{4}\right)_{3}+\mathrm{Fe}_{2}(\mathrm{OH})_{4} \\
\mathrm{Fe}_{2}\left(\mathrm{SO}_{4}\right)_{3}+6 \mathrm{H}_{2} \mathrm{O}=2 \mathrm{Fe}(\mathrm{OH})_{3}+3 \mathrm{H}_{2} \mathrm{SO}_{4}: \\
72293^{\circ}-\text { Bull. } 529-13-5
\end{gathered}
$$


All the waters from copper mines (1-18) are sulphate solutions. Carbonates are determined in only one of these-No. 1, which was taken at some distance from any known ore body. The combined acid radicles of several are, however, insufficient to balance the positive ions - $\mathrm{a}$ fact that suggests the probability that some of the metals are balanced by carbon dioxide or by ions containing carbon dioxide. The average sulphate $\left(\mathrm{SO}_{4}\right)$ of 18 samples of water from copper mines is 5,695.3 parts per million. This figure is increased greatly by sample 5 , an exceptionally strong sulphate solution. The average sulphate of the 17 other samples is $1,850.4$ parts per million. The average sulphate of 19 samples from gold and silver mines is $11,266.8$ parts per million; if the sample of concentrated water (No. 23) from the Comstock lode is eliminated the average of 18 samples is 276.04 . In seven of the waters from copper mines the acidity has been determined, the average being 291 parts per million, calculated as sulphuric acid $\left(\mathrm{H}_{2} \mathrm{SO}_{4}\right)$. Samples 8 and 9 show appreciable acidity, notwithstanding a deficiency of sulphate ions to balance the metals. In at least 12 samples there $\cdot$ is no free acid. At least eight samples from copper and precious-metal mines $(1,2,3,4,27,28,33,34)$ are alkaline.

Chlorides.-The salt $(\mathrm{NaCl})$ in sedimentary rocks may be dissolved by ground water, and in some places it is a source of commercial supply. From the available analyses it appears that in many regions the amount of salt in such rocks is small. The chlorine content of composite samples of 78 shales and 253 sandstones is only a trace, and an analysis of a composite of 345 limestones shows only 0.02 per cent. ${ }^{1}$ A few rock-making minerals, such as chlorapatite, scapolite, haüyne, and nosean, contain combined chlorine; but all of these except apatite occur mainly in rocks of very rare types. In some rocks chlorine is present probably as sodium chloride in the solid particles contained in fluid inclusions.

Apatite, though widespread in igneous rocks, is a very stable mineral and consequently can not be regarded as an important source of chlorine, although it may afford small amounts when exposed to favorable conditions of weathering. The average chlorine content of igneous rocks, according to F. W. Clarke, is 0.06 per cent.

Chlorine is present in nearly all natural waters, which derive it from fine salt or salt water from the sea or other bodies of salt water. The fine salt is carried by the wind and precipitated with rain. ${ }^{2}$ The amount of chlorine in bodies of natural water varies with remarkable constancy with variations in the distance of the bodies from the shore. Several determinations of water from bodies very near the seashore

1Clarke, F. W., The data of geochemistry, 2d ed.: Bull. U. S. Geol. Survey No. 491, 1911, p. 28.

2 Jackson, D. D., The normal distribution of chlorine in the natural waters of New York and New England: Water-Supply Paper U. S. Geol. Survey No. 144, 1905. 
show 10 to 30 parts of chlorine per million; in bodies a few miles away it is generally about 6 parts per million; in bodies 50 miles from shore it is generally less than 1 part per million.

In arid countries dust containing salt doubtless contributes chlorine to mine waters. Penrose, ${ }^{1}$ discussing the distribution of the chloride ores, pointed out long ago that these minerals form most abundantly in undrained areas.

The average chlorine content of the 18 analyses of waters from copper mines is 63.9 parts per million. In three of these chlorine is not reported, but in two of the three it was not looked for. The average of the 15 samples is 76.7. The samples from gold and silver mines carried less chlorine than those of copper mines, the average of 19 being 23.8. Exclusive of four samples showing traces, the average is 30.2. The chlorine content of waters of well-drained areas like those of Ducktown, Tenn., and Creede, Colo., is conspicuously low. The amount of chlorine in deposits in or near arid regions or near the sea is greater. Two samples from Butte, Mont., show a large content of chlorine. In general the chlorine content in the samples analyzed is much lower than in samples of water obtained by Don ${ }^{2}$ from a large number of Australasian mines and considerably lower than a former estimate ( 873 parts per million) given by me in a previous paper $^{3}$ on the concentration of gold by cold solutions.

Carbonates.-Since sulphuric acid tends to drive carbon dioxide out of solution, it would not be supposed that highly carbonated waters would be common in mines where the ore carried much pyrite. That small amounts of acid sulphate and carbonates may exist in the same solution is shown, however; by several analyses. In the acid waters under consideration the carbonates of the bases would necessarily be present as bicarbonates, although this fact is not indicated in all the analyses.

Carbonates were determined in only one sample of water from copper mines but are probably present in others. Carbonates are shown in 13 waters from gold and silver mines, the average of the 13 samples being 224.6 parts per million. The average of the 19 samples from precious-metal mines is 153.7 parts. Two waters from the Geyser mine, Custer County, Colo., and two from Creede, Colo., contain, in addition to the carbonate radicle $\left(\mathrm{CO}_{3}\right)$, considerable excess carbonate calculated as carbon dioxide $\left(\mathrm{CO}_{2}\right)$, but this is not included in the average. Several analyses of waters from mines of Butte, Mont., show insufficient carbon dioxide in the bicarbonate

1 Penrose, R. A. F., jr., The superflcial alteration of ore deposits: Jour. Geology, vol. 2, 1894, pp. 314-316

2 Don, J. R., The genesis of certain auriferous lodes: Trans. Am. Inst. Min. Eng., vol. 27, 1898, p. 654.

8 Emmons, W.H., The agency of manganese in the superficial alteration and secondary enrichment of gold deposits in the United States: Bull: Am. Inst. Min. Eng., 1910, p. 774; Jour. Geology, vol. 19, 1911, p. 20. To obtain this estimate many partial analyses were included. These are not given in the tablo on pages $62-63$. 
state to satisfy the bases, hence both normal and bicarbonates were assumed as present and the summation was raised to correspond. ${ }^{1}$

Silica.-The analyses show that appreciable silica is dissolved even in strongly acid mine waters. Very little is known concerning the conditions that favor the solution of silica in such waters. Solutions that contain much alkali and carbonate generally carry larger quantities of silica, although the one that carries the most silica is a concentrated sulphate solution from the Comstock lode. The average silica content of 18 waters from copper mines is 44.7 ; that of waters from 19 precious-metal mines is 69.4 .

Arsenic and antimony.-Arsenic and antimony compounds are dissolved in some mine waters, for there is evidence that minerals containing these metals are deposited from cold solutions. Only traces of arsenic and antimony are reported in the analyses, but Dr. Hillebrand notes that considerable arsenic was present in a precipitate from a filtered sample of water collected by Waldemar Lindgren at Grass Valley, Cal., where the gold ores carry arsenical minerals. Traces of arsenic are reported in three waters from Butte, Mont.

Nitrates. - Nitrates are not abundant in mine waters. In only one analysis $(20)$ is nitrate $\left(\mathrm{NO}_{3}\right)$ reported (1.60 parts per million), and this in a water that was questionably representative, for it appears to have been imperfectly filtered. ${ }^{2}$

Phosphates.-Traces of phosphate are reported in eight mine waters. One sample contained 1.5 parts per million; others contained none, if determinations for phosphate were made.

Potassium.-Potassium has been found in all the samples of waters from copper mines where it was looked for. The average of 13 samples is 10.7. In the samples from gold and silver mines it varied from 1 part to 254 parts per million, the average of 14 samples being 53.9. If it is assumed to have been absent in the five samples in which it is not reported, the average content of 19 samples is 39.7.

Sodium.-Owing to its greater solubility in sulphate solutions, sodium is generally more abundant than potash in these mine waters. The 18 samples of waters from copper mines contained an average of at least 24.8 parts per million, and 13 samples in which potash was determined averaged 34.4. The average sodium content of 14 samples of water from precious-metal mines is 131.6 parts per million.

Calcium.-The average calcium content of 18 samples of waters from copper mines is 209.3 parts per million. The average of 19

1 Hillebrand, W. F., Composition of mine waters, in Weed, W. H., Geology and ore deposits of the Butte district, Montana: Prof. Paper U. S. Geol. Survey No. 74, 1912, p.101.

2 Emmons, S. F., The mines of Custer County, Colo.: Seventeenth Ann. Rept. U. S. Geol. Survey, pt. 2, 1896, p. 462; analysis of water from Geyser mine, Silver Cliff, Colo. See also statement of W. F. Hillobrand, analyst, on page 460 of same report. 
samples of waters from precious-metal mines is 144.2 parts. Calcium was determined in every sample.

Magnesium.-In 18 samples of waters from copper mines magnesium averages 47.4 parts per million. In 19 samples of waters from precious-metal mines it averages 390 parts. In three samples of such waters it is not reported. In 16 waters of precious-metal mines it averages 445.2 parts per million. The remarkable concentration of magnesium in sample 23 (an exceptional water) brings the average far above that of calcium, but notwithstanding the greater solubility of its sulphate, magnesium exceeds calcium in only three of the samples.

Aluminum.-Like the alkalies and alkaline earths, aluminum is readily dissolved from the silicates of the ore or from the wall rock. In general it is more abundant in sulphate waters than in those that carry considerable carbonate.

The average aluminum in 12 samples from copper mines is 81.5 parts per million. Singularly enough it is absent in five waters from mines at Butte, Mont., which are in "granite." It is reported from only eight samples of water from precious-metal mines, the average being $1,209.9$. If analysis 23 , which shows exceptionally high alumina, is excluded, the average of the 18 other samples is only 1.3 parts per million.

Manganese.-In 16 samples of water from copper mines the average content of manganese is 40.8 parts per million. In one analysis it is not reported; in another a trace is shown. It is especially abundant in the waters from Cananea, Sonora, Mexico.

The average of 13 samples from precious-metal mines is 81.5 parts per million. It is not reported in six. The variation in manganese content is exceedingly great. Only two waters, one from the Comstock lode and another from the Stanley mine, Georgetown, Colo., contain more than a few parts per million.

Iron.-All the 18 samples of water of copper mines contain iron. In two of them it is stated as total iron; in 14 samples ferrous iron is present, the average of these being 303.9 parts per million; ferric iron is present in 7 samples. Ferrous iron was probably determined in 15 samples, the average of the 15 being 23.3 parts per million indicating that in such waters, even in the zone where air is admitted, ferrous iron predominates in many mines. None of the analyses of samples taken underground at Cananea (Nos. 14-18) show ferric iron, yet the sample taken from the concentrates, where it circulates over the tables in contact with ore and air, contains appreciable ferric iron.

In two samples of water from precious-metal mines iron is stated as total iron. Ferrous iron is reported from 5 of the 17 samples remaining, the average being 34.8 parts per million; or if it was determined in all 17 samples, the average is 10.3 parts per million. 
It is highest in the water from the Stanley mine. Appreciable ferric iron is reported in six samples, its average being 841 parts per million. Excluding sample 23, from the Comstock lode, the average of the other five samples is only about 5 parts per million. This is lower than the ferric iron in waters from copper mines and very much lower than the ferric iron determined by Don in many waters from Australasian mines.

Copper.-Copper, dissolved as sulphate, is abundant in many mine waters. In some mines at Butte, Mont., Ducktown, Tenn., Jerome, Ariz., and Rio Tinto, Spain, and in the Ballygahan mine, Wicklow, Ireland, the waters during certain periods of development have been sufficiently cupriferous to yield marketable quantities of copper. The average of 13 samples from copper mines is 3,690 parts per million. In five samples it is absent or is not reported. The water from the Mountain View mine at Butte, Mont., is by far the most highly cupriferous. Exclusive of this the average of 12 samples is only 195.5 parts per million. Copper is reported also in a concentrated water from the Comstock lode (No. 23) and in water from the Stanley mine at Georgetown, Colo. (No. 35), and traces are present in waters from other precious-metal mines (19 and 20).

Zinc.-The zinc content of the waters of 15 copper mines averages 140.3 parts per million. The average of 19 samples of preciousmetal mines is 6.7 parts per million. In the seven of these from which it is reported the average is 18.3 parts per million. Some waters from mineral deposits of the Mississippi Valley contain abundant zinc.

Gold and silver.-Small amounts of gold and silver have been detected in waters from the Comstock lode, ${ }^{1}$ and gold has been determined in a water from the Homestake mine, in South Dakota. ${ }^{2}$ Traces of both gold and silver are present in waters from the Granite vein Montana.

\section{CHANGES IN COMPOSITION DEPENDING ON DEPTH.}

Waters descending from the surface through sulphide ore deposits pass through a changing chemical environment and are continually changing in chemical composition. In the oxidized zone, as already stated, they are oxidized waters and acid waters; when they pass below the region where oxygen is in excess their acidity and their state of oxidation change. Their reaction on some sulphides produces hydrogen sulphide, and their reaction on silicates and carbonates decreases acidity. Iron is generally abundant in waters of pyritic ore bodies, and the degree of the oxidation of the iron is important as an index to the state of oxidation of the water. Mineral waters

1 Reid, J. A., The structure and genesis of the Comstock lode: Bull. Dept. Geology Univ. California, vol. 4, 1906, pp. 189, 192.

2 Sharwood, W. J., Analyses of some rocks and minerals from the Homestake mine, Lead, S. Dak.: Econ. Geology, vol. 6, 1911, p. 742 . 
may thus be divided into several groups, depending on the degree of their oxidation and their acidity. Nos. 9, 10, and 11, from Ducktown, Tenn., are samples of waters containing acid and ferric sulphate. Samples of acid and ferrous sulphate water are represented by No. 7, from the Ruth mine, Ely, Nev.; Nos. 8, 12, and 13, from Ducktown, Tenn.; No. 35, from the Stanley mine, Georgetown, Colo.; and No. 32, from the Rothschönberger Stolln, Freiberg, Germany.

Of the 37 samples of water analyzed 13 or more carry no free acid, and 9 of these are alkaline. The alkaline waters include two $(33,34)$ from the deep levels of mines at Creede, Colo., where they descended to depths of 1,300 feet or more before they issued at the drain level. As would be supposed, ferric iron is not present in any of the nine analyses of alkaline waters.

Samples 27 and 28 are waters collected by Waldemar Lindgren from the 400-foot levels in the Federal Loan and Black Prince mines at Nevada City, Cal. As the temperature of these waters when collected was the same as that of the surrounding rock, they come, presumably, from the meteoric circulation. Both are alkaline and both form yellow-brown deposits consisting principally of hydrated iron oxide, alumina, and silica. These waters were clear when bottled, but when opened after several months both contained dark-colored deposits of silica, hydroxides, and sulphides. Dr. W. F. Hillebrand, who made the analyses, detected no hydrogen sulphide in either water, although both appeared to contain a little thiosulphate. Sample 27 contained metallic sulphides in solution, and an odor of hydrogen sulphide was noticeable near the place where it was obtained. Sample 28 contained no metallic sulphides and emitted no noticeable odor of hydrogen sulphide. At least eight additional samples $(8,9,10,11,12,13,33$, and 34$)$ have been tested for hydrogen sulphide, with negative results. Sample 2 deposited sulphur and ferrous sulphides.

Although hydrogen sulphide is rare in mine waters, it forms when certain sulphides are in contact with acid. When exposed to the air it oxidizes rapidly. It is not supposed that it would accumulate, at least not in the zone where air has free access to the deposits, where most samples of mine waters are taken. On descending to greater depths it would be used up according to the reaction-

$$
\mathrm{Fe}_{2}\left(\mathrm{SO}_{4}\right)_{3}+\mathrm{H}_{2} \mathrm{~S}=2 \mathrm{FeSO}_{4}+\mathrm{S}+\mathrm{H}_{2} \mathrm{SO}_{4} \text {, }
$$

or it might be used up also in the precipitation of metallic sulphides from sulphates. Whether it would be used first to form ferrous sulphate and afterward to precipitate metallic sulphides can not be shown, but this order of action occurs at least under some conditions. Samples 8 and 9, from Ducktown, Tenn., are especially instructive in this connection, for No. 8 contains much ferrous iron and no ferric iron, whereas No. 9 contains much ferric iron and only 1.3 parts of 
ferrous iron. The ore through which sample 8 passed before issuing where it was taken is more than 90 per cent pyrrhotite, which generates hydrogen sulphide rapidly. The ore through which sample 9 passed contains chiefly chalcopyrite and lime silicates, with but little pyrrhotite. This water contains considerable iron, almost all in the ferric state. Since No. 8 contains even more copper than No. 9, it would be supposed that the ferric sulphate is reduced to ferrous sulphate $\left(\mathrm{FeSO}_{4}\right)$ before copper sulphide is precipitated, as in this water the iron is entirely reduced to the ferrous state while there is still a considerable amount of copper in solution. It is noteworthy that the alkaline waters (samples $27,28,33,34$ ) contain appreciable quantities of carbonates, with lime, potash, and soda. They carry also a certain concentration of sulphates. Two of the four alkaline waters from Nevada City, Cal., and two from Creede, Colo., have descended through considerable unoxidized material. Alkaline waters have not received sufficient attention in studies of sulphide enrichment.

Samples 14, 15, 16, and 17 are from the Capote mine, at Cananea, Mexico. The deposit is in an area of quartzite and other rocks intruded by diorite porphyry. The ore is in part of the disseminated type and carries pyrite, chalcopyrite, and zinc blende, with secondary chalcocite. I can not state the vertical range of chalcocite in this deposit, but it is not so abundant at the 900 -foot level, where sample 16 was obtained, as it is at the 300 -foot level, where sample 14 was obtained. Sample 14 contains 970 parts of free acid per million, whereas the samples taken at greater depths contain no free acid.

The two pairs of samples Nos. 10 and 11 and Nos. 12 and 13 are from unused shafts at Ducktown, Tenn. As stated above, the samples were taken by lowering bottles equipped with asbestos filters to the desired depth, then removing the covers from the filters and allowing the bottles to fill. The waters from the open shafts are diluted by a large proportion of surface water, so they are less concentrated than mine waters that have traveled considerable distances through the rocks. In taking samples 10 and 11 the water was disturbed, so that the analyses of these samples are of less value; samples 12 and 13 were taken with special precautions to prevent agitation and show very well the difference in the mineral content of the waters at different depths. The water from the surface (No. 12) contains more than twice as much free acid as the deeper water. No. 13, taken below water level, is more concentrated with respect to silica, calcium, magnesium, aluminum, zinc, and iron, but the concentrations of potassium, sodium, and manganese are closely similar. The amount of copper is greatly decreased. This suggests that at a depth of 37 feet other metals are being taken into solution but the greater part of the copper has already been deposited. Although the deeper water contains more ferrous iron and more ferric iron than that at the water level, the proportion 
of ferric to ferrous iron has increased with increase of depth, showing just the reverse of the conditions expected. It is thought that the increase in the proportion of iron in the solution with increase of depth has been brought about by reaction of acid on pyrrhotite and also that ferric iron has decreased near the surface by hydrolyzation. The filter paper was colored red by a dustlike iron precipitate, probably basic ferric sulphate, formed presumably near the surface and held in suspension in the water. The formation of this precipitate probably accounts for the very small concentration of ferric iron at the surface of the standing water and possibly also for the somewhat smaller amount of total sulphate held in solution near the surface. This precipitate would probably not form so extensively under conditions affording free circulation.

The four waters from Freiberg, Germany (samples 29, 30, 31, 32), agree in containing considerable zinc and manganese. One of them on standing forms a deposit consisting chiefly of manganese oxide and some zinc oxide.

Sample 20 is from the 2,000-foot level of the Geyser mine at Silver Cliff, Colo. This water contained some nitrate, which is uncommon in analyses of mine waters.

Several of these waters do not contain a sufficient amount of the acid ions to hold in solution the metallic portion. If carbon dioxide was determined in such waters, a part of the metals must be dissolved as silicates or possibly even as hydroxides.

PRECIPITATES FROM MINE WATERS UNDER SUPERFICIAL COINITIONS.

Many waters, after issuing from mineralized areas, deposit copious precipitates. In some mining districts the streams which carry away the underground drainage from the adits have stained their beds for great distances from the points of issue. In certain of these areas, as at Cananea, Mexico, and Bingham, Utah, the gravels above the present streams are cemented by iron oxides, showing that the processes of precipitation at the surface were operative before the mines were opened. These deposits, formed under atmospheric pressure and in the presence of oxygen, are very different from the deposits of secondary ore that are formed at depths where sulphide enrichment is assumed to take place. Few if any of them are workable for the more valuable metals. Nearly all of them consist largely of the colloidal compounds, such as the hydrous iron oxides, hydrous aluminum compounds, and hydrous silica.

Many samples of waters quickly become cloudy after they have been filtered, either because of their filtration in air or because of slight changes in their temperature; or, if they have been taken from low depths, because of decrease in pressure precipitation takes place. Two samples of water taken from adits at Creede, Colo., and filtered in the presence of air deposited light-gray precipitates, presumably compounds of aluminum and silica. Of six samples 
collected at Ducktown, Tenn., all were likewise clouded. Two of these samples, one taken 37 feet and the other 55 feet below the water level, were filtered under water, and although the air spaces left in the necks of the bottles were exceedingly small the samples clouded in a few hours. Several samples from Butte, Mont., deposited solids before analyses were made.

The results of analyses of four samples of material precipitated from mine waters are stated in the table below. Sample 1 is from a water in the Stanley mine, near Georgetown, Colo. (No. 35 in table above). Sample 2 is from a mine in Freiberg, Saxony. The sample was taken from workings that had been flooded 135 years. It contained much manganese and considerable zinc. Sample 3 is a slime collected in the Federal Loan mine, ${ }^{1}$ near Nevada City, Cal., where the water represented by sample 23 of the table on page 62 issued from the wall rock. Of this analysis Dr. Hillebrand makes the following remarks: ${ }^{2}$

The bottle was filled with a black slimy matter emitting a disgusting odor of organic decomposition. The cork was forced out with ease by imprisoned gas, chiefly consisting of $\mathrm{CO}_{2}$ and $\mathrm{CH}_{4}$. The slime was said to have been white when collected; the subsequently developed black color is due to iron sulphide. Aside from organic matter and water, the deposit is essentially ferric oxide with a little arseniate, calcium carbonate with a little magnesium carbonate, and manganese as $\mathrm{MnO}_{2}$, besides gelatinous silica and fragments of minerals.

A deposit collected by Lindgren in the drain tunnel of the Providence mine, near Nevada City, Cal., when dried, formed dirty white masses and coarse green lumps. An analysis of some of the green pieces is given in column 4 of the following table:

Analyses of muds precipitated from mine waters.

\begin{tabular}{|c|c|c|c|c|}
\hline & 1 & 2 & 3 & 4 \\
\hline 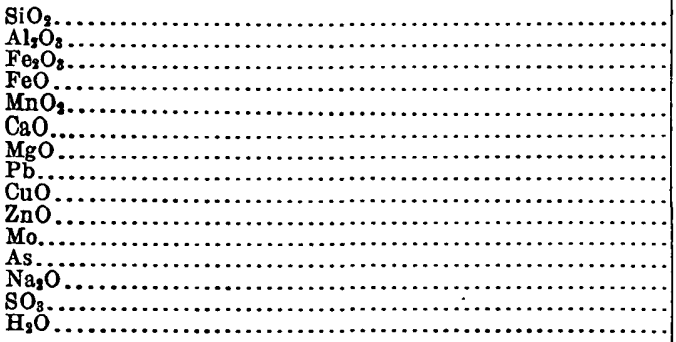 & 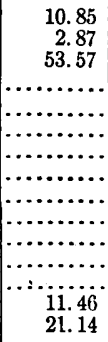 & 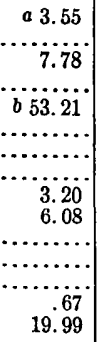 & 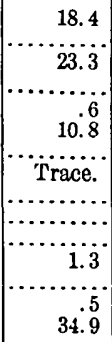 & 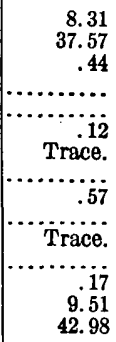 \\
\hline & 99.89 & 99.48 & 99.8 & 99.67 \\
\hline
\end{tabular}

a Insoluble residue. $\quad b$ Some $\mathrm{MnO}$ present. The analysis as stated gives $0,8.43$, and $\mathrm{MnO}, 44.78$.

1. Precipitate filtered from water of Stanley mine. Jones, L. J. W., Ferric sulphate in mine waters and its action on metals: Proc. Colorado Sci. Soc., vol. 6, 1900, 1.. 48.

2. Deposit from a mine at Frelberg, Saxony, taken from workings that had been flooded 135 years. Contains cobalt oxide, 1.36; cadmium oxide, 0.19; lead oxide, 3.45. Beck, Richard, Lehre von den Erzlagerstätten, 1901, p. 402

3. A deposit from water from Federal Loan mine, near Nevada City, $\mathrm{Cal}$. $\mathrm{CaO}$ equals $\mathrm{CaCO}_{3}$ and $\mathrm{MgCO}_{3}$; organic material calculated with water. Insoluble material included with $\mathrm{SiO}_{2}$. Lindgren, Waldemar, The gold-quartz veins of Nevada City and Grass Valley districts, California: Seventeenth 'Ann. Rept. U. S. Geol. Survey, pt. 2, 1896, p. 122 .

4. Part of deposit in drain tunnel of Providence mine, near Nevada City, Cal. Idem, p. 123.

1 Lindgren, Waldemar, The gold-quartz veins of Nevada City and Grass Valley districts, California: Seventeenth Ann. Rept. U. S. Geol. Survey, pt. 2, 1896, p. 121.

2 Idem, pp. 122-123. 


\section{OXIDATION AND SOLUTION OF CERTAIN METALIIC SULPHIDES.}

\section{FACTORS CONCERNED.}

In the presence of air the oxidation and the solution of the metallic sulphides take place simultaneously and it is difficult if not impossible to consider the two processes separately. The rate of solution depends on many factors, amping them (1) the solubility of the material in water, (2) the molecular and physical structure of the material, (3) the solubility of the salts formed by oxidation, hydration, and related processes, (4) the composition, concentration, temperature, and pressure of the solutions, (5) the mineral and chemical environment, (6) the rapidity of circulation, and (7) the potential or electromotive force of the mineral compared with the electromotive force of the mineral or minerals with which it is in contact.

It is noteworthy that the natural conditions are not those which commonly exist in the laboratory, for in nature the solvent is in motion and is therefore bringing new and generally unsaturated solutions into contact with bodies that are dissolving. Thus, if sufficient time is afforded even minerals that in the laboratory are most nearly insoluble may by natural processes be completely dissolved. Even salts so insoluble as cerargyrite and anglesite may be entirely removed from the outcrops of ores.

The solubilities of the sulphates that are formed by these reactions are nevertheless important, for, other conditions being similar, it would be supposed that the metals that have the most soluble sulphates would be most readily dissolved. As shown by the table of solubilities, iron, zinc, and copper have highly soluble sulphates, whereas the solubilities of the sulphates of lead and silver are low. Although galena (p. 59) is readily attacked by cold dilute sulphate solutions it is nevertheless slow to dissolve in metalliferous deposits. This fact may indicate why lead lags behind iron, copper, and many other metals in its migration downward in ore deposits.

Pyrite and marcasite, which have the same formula, oxidize and dissolve at different rates, owing, probably, to a difference in their molecular structure. Cellular pyrite will oxidize more rapidly than dense pyrite.

The importance of an oxidizing environment as a condition for the solution of some metals should be emphasized.

All the experimental evidence shows that the oxidation and solution of the sulphides in pure water is slow. Under natural conditions it may be accelerated somewhat by carbon dioxide, which is generally dissolved in rain water and forms a weak acid that may start solution. Sulphuric acid, a more powerful solvent, is released in the presence of iron sulphides. 
The recent work of Gottschalk and Buehler ${ }^{1}$ shows that séveral sulphides in contact in water form weak batteries. The current flows from the mineral having the higher. potential to the one having the lower potential, which is dissolved, the one with higher potential being to some extent protected from solution. These experiments should probably be interpreted as indicating particularly the relations that exist at the beginning lution, for the electromotive force varies with variations in the soutions, which, as already stated, are continually changing. The relations considered are those which exist in the presence of free air. Under natural conditions all portions of oxidizing deposits are not equally accessible to atmospheric oxygen. Some sulphides that are readily dissolved in dilute acid sulphate in the presence of air are practically insoluble in its absence. Chalcocite, for example, is highly stable in portions of deposits where air is excluded, but in the presence of air and acid it dissolves very readily. The solution and oxidation of the sulphides depend on so many factors that general statements can not be applied to all conditions or combinations, each mineral association presenting, in a sense, a problem in itself.

\section{RELATIVE RATE OF SOIJTION OF SEVERAL SULPHIDES IN AN OXIDIZING ENVIRONMENT.}

The following table shows the order of oxidation of some of the sulphides, according to the views of several investigators. The sulphides that are most readily attacked are placed highest in each series. The differences that appear between certain of the series might be interpreted as indicating differences which should be expected under natural conditions, the order of oxidation depending on the environment.

Order of oxidation of sulphides, according to several authorities.

\begin{tabular}{|c|c|c|c|c|c|c|}
\hline 1 & 2 & 3 & 4 & 5 & 6 & 7 \\
\hline $\begin{array}{l}\text { Iron. } \\
\text { Copper. } \\
\text { Zinc. } \\
\text { Lead. } \\
\text { Silver. }\end{array}$ & $\begin{array}{l}\text { Arsenopyrite. } \\
\text { Pyrite. } \\
\text { Chalcopyrite. } \\
\text { Sphalerite. } \\
\text { Galena. } \\
\text { Chalcocite. }\end{array}$ & $\begin{array}{l}\text { Chalcocite. } \\
\text { Pyrite. }\end{array}$ & $\begin{array}{l}\text { Chalcocite. } \\
\text { Pyrrhotite. } \\
\text { Pyrite. }\end{array}$ & $\begin{array}{l}\text { Chalcocite. } \\
\text { Bornite. } \\
\text { Pyrrhotite. } \\
\text { Chalcopyrite. } \\
\text { Pyrite. }\end{array}$ & $\begin{array}{l}\text { Sphalerite. } \\
\text { Chalcocite. } \\
\text { Galena. } \\
\text { Pyrite. } \\
\text { Cbalcopyrite. } \\
\text { Argentite. }\end{array}$ & $\begin{array}{l}\text { Pyrrhotite. } \\
\text { Sphalerite. } \\
\text { Galena. } \\
\left\{\begin{array}{r}\text { Chalcopyrite } \\
\text { and pyrite. }\end{array}\right.\end{array}$ \\
\hline
\end{tabular}

1. Van Hise, C. R., Some principles controlling the deposition of ores: Trans. Am. Inst. Min. Eng.,

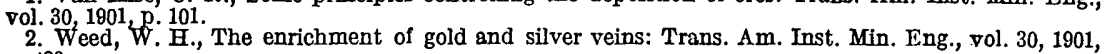
p. 429 .

3. Lindgren, Waldemar, The copper deposits of the Clifton-Morenci
Geol. Survey No. 43, 1905, p. 180. At some places in Clifton district.

Geol. Survey No. 43,1905, p. 180 . At some piaces in Clifton district. 4. Emmons, W. H., and Laney, F. B., Preliminary report on the mineral deposits of Ducktown, Tenn.:
Buil. U.S. Geol. Survey No. 470, 19i1, pp. 151-172. Above the water level.

5. Vogt, J. H. L., Problems in the geology of ore deposits, in Pošepny, Franz, The genesis of ore deposits, 1902, pp. 676-677. Order of attack of sulphides by ferric chloride.

6. Gottschalk, V. H., and Buehler, op. cit., p. 31. Table showing relative potential of several sulphides.

7. Wells, R. C. Table showing rate of attack of 0.057 normal solution $\mathrm{H}_{2} \mathrm{SO}$, on several sulphides. (See p. 59.)

1 Gottschalk, V. H., and Buehler, H. A., Oxidation of sulphides: Econ. Geology, vol. 7, 1912, p. 16. 
As already stated, the relative rate of solution of the sulphides probably can not be expressed in a hard and fast series, yet certain relations hold under many, probably under most conditions. Sphalerite is so readily dissolved by acid in the absence of air that at many places it is removed even from primary ores that are in a reducing environment. Consequently in many deposits the order of the rate of solution of sphalerite, chalcocite, and pyrrhotite in acid where oxygen is in great excess can not be stated. Possibly sphalerite should be placed at the head of the series shown in the table; possibly it should be placed between pyrrhotite and chalcopyrite.

The relative rate at which chalcocite and pyrite are removed where oxygen is in excess is shown by the relations of these minerals in several deposits. Lindgren ${ }^{1}$ notes that in the Morenci district chalcocite is often oxidized, while much pyrite remains. At Ducktown, Tenn., the "black copper" ores, composed of pyrrhotite, pyrite, and chalcocite, which have replaced the iron sulphides near the water level, quickly lose their copper content when the ores are exposed to highly oxygenated waters by the artificial depression of the level of the ground water. Solution is so rapid there that it is difficult to obtain rich chalcocite ores in mines that have been opened below the water level for a few years. At Ducktown, as at Morenci, chalcocite, where oxygen is present, is dissolved more rapidly than pyrite.

The pyrite in some of the leached chalcocite ore of Ducktown remains almost unaffected by the leaching, its bright crystals being distributed through a dark mass of sooty black pyrrhotite, which has been partly altered and from which practically all copper has been removed. The order of solution indicated appears to be chalcocite, pyrrhotite, pyrite.

As shown by Gottschalk and Buehler, galena oxidizes more readily than pyrite. The oxidation product, lead sulphate, is so insoluble, however, that it remains to cover the crystals of galena and serves to delay further action. Galena remains in the outcrops of many sulphide ore bodies after iron and zinc compounds have been completely altered. It is said that some ore deposits in the Wisconsin zinc district were discovered by farmers who plowed up crystals of galena.

Enargite also is an exceedingly persistent mineral in outcrops. According to Reno Sales ${ }^{2}$ it is commonly found in or near oxidized ores of the Butte copper mines, and it is said that at Tintic enargite remains in the oxidized ores even after galena has been dissolved. Series 5 (table on p. 76), based on experiments of Vogt, shows the rate of attack by strong solutions of ferric chloride, an oxidizing agent, on several sulphides. Chalcocite was dissolved quickly, as it is

1 Lindgren, Waldemar, The copper deposits of the Clifton-Morenci district, Arizona: Prof. Paper U. S. Geol. Survey No. 43, 1905, p. 180.

Sales, R. H., Discussion of paper by F. L. Ransome, on "Criteria of downward sulphide enrichment": Econ. Geology, vol. 5, 1910, p. 681. 
in secondary sulphide zones, where it is exposed to solution in the presence of air. Bornite also was attacked at a relatively rapid rate. Stokes ${ }^{1}$ showed that dilute ferric sulphate attacks chalcopyrite more readily than pyrite. All these experiments and observations seem to indicate that in the zone of oxidation in many deposits the sulphides are dissolved in the following order: Sphalerite(?), chalcocite, pyrrhotite, chalcopyrite, pyrite, galena, enargite. This series does not correspond exactly with the series of Wells (column 7 of table), which was obtained from experiments with sulphuric acid alone.

NET RESUlTS OF CHEMICAL CHANGES DURING OXIDATION OF CERTAIN ORES.

The results of the chemical changes that take place during the oxidation of sulphide deposits depend largely on the minerals that form the deposits. Some gangue minerals disappear completely, others are partly dissolved, and some elements of still other minerals remain in the mass in new combinations. Not many sets of analyses of sulphide ore and of corresponding oxidized ore from the same deposit are available. The data for the deposits of Ducktown, Tenn., are fairly satisfactory. The gossans of the copper deposits have been smelted for iron, and average analyses of thousands of tons are available from furnace records, through the courtesy of Mr. R. H. Lee and Mr. John B. Newton. Yearly averages from the smelters of sulphide ore from the same deposits are available through the courtesy of the officers of the Tennessee Copper Co. and the Ducktown Copper Sulphur \& Iron Co. On the assumption that the average of several specific-gravity determinations of the gossan (2.2) applies to the entire mass and that the average specific gravity of the sulphide ore is 4.05 , the following table has been prepared to indicate the nature of the change by which primary ore becomes gossan. Column 1a shows the percentage weight of the constituents of the primary sulphide ore of the Mary mine (average of all ore smelted in 1906). Column 1b shows its percentage weight times its specific gravity (4.05) and may be regarded as expressing the number of grams in 100 cubic centimeters of the primary ore. Column 2a shows the chemical composition of the gossan (average of two large shipments). Column $2 \mathrm{~b}$ gives its percentage weight times its specific gravity (2.2, corresponding to 39 per cent porosity). Column 3 shows the gain and the loss of several constituents. Losses are shown for sulphur, silica, alumina, lime, iron, zinc, copper; gains for oxygen and water. Carbon dioxide and magnesia were not determined in the analyses of gossan but were probably almost entirely carried away.

${ }^{1}$ Stokes, H. N., On pyrite and marcasite: Bull. U. S. Geol. Survey No. 186, 1910, p. 33. 
Chemical changes by oxidation processes at Ducktown, Tenn.

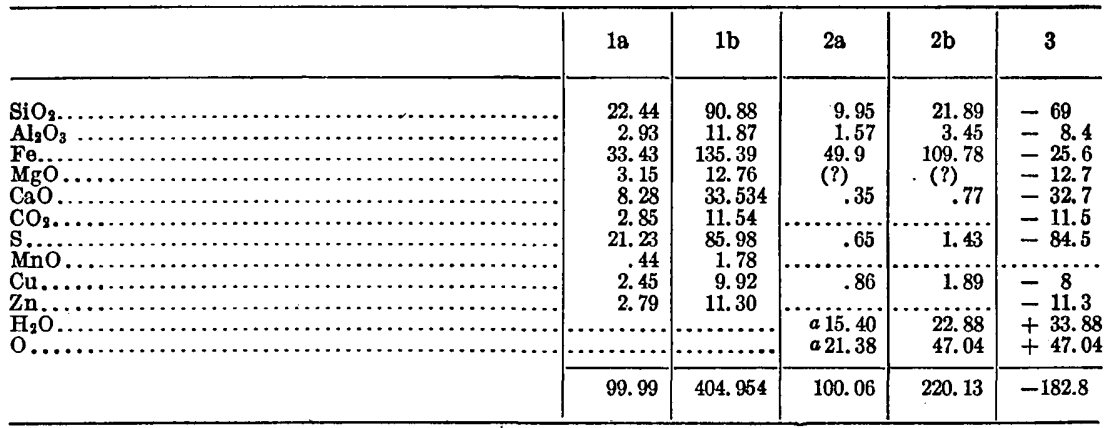

$a \mathrm{H}_{2} \mathrm{O}$ and $\mathrm{O}$ are estimated, on the assumption that the $\mathrm{Fe}$ is $\ln$ limonite.

Mineralogically the primary ore consists of pyrrhotite, pyrite, chalcopyrite, sphalerite, actinolite, calcite, tremolite, quartz, pyroxene, garnet, zoisite, chlorite, and micas. Small quantities of bornite, specularite, and magnetite are present and at some places graphite, titanite, and feldspars. The following is a close approximation to the mineral composition of the unoxidized ore:

Composition of primary ore at Ducktown, Tenn.

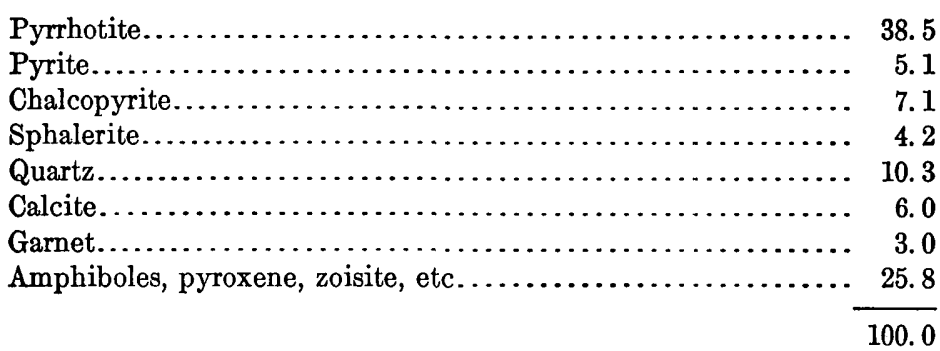

Oxidation has changed this ore into a gossan consisting essentially of limonite with a little silica and kaolin, carrying a fraction of 1 per cent of copper and sulphur.

The table on page 80 shows the results of an analysis of rich concentrates of sulphide ore from the Montana Tonopah mine, Tonopah, Nev., and an analysis of rich oxidized ore from the Valley View vein of the same district. The principal primary minerals in this district, according to Spurr, ${ }^{1}$ are quartz, carbonates, adularia, some sericite, and sulphides of silver, antimony, copper, iron, lead, and zinc. Limonite, wad, and horn silver are deposited in the oxidized zone, with some silver bromide, silver iodide, and free gold.

1 Spurr, J. E., Geology of the Tonopah mining district, Nevada: Prof. Paper U. S. Geol. Survey No. 42, 1905, p. 80. 
Analyses of ores from Tonopah, Nev.

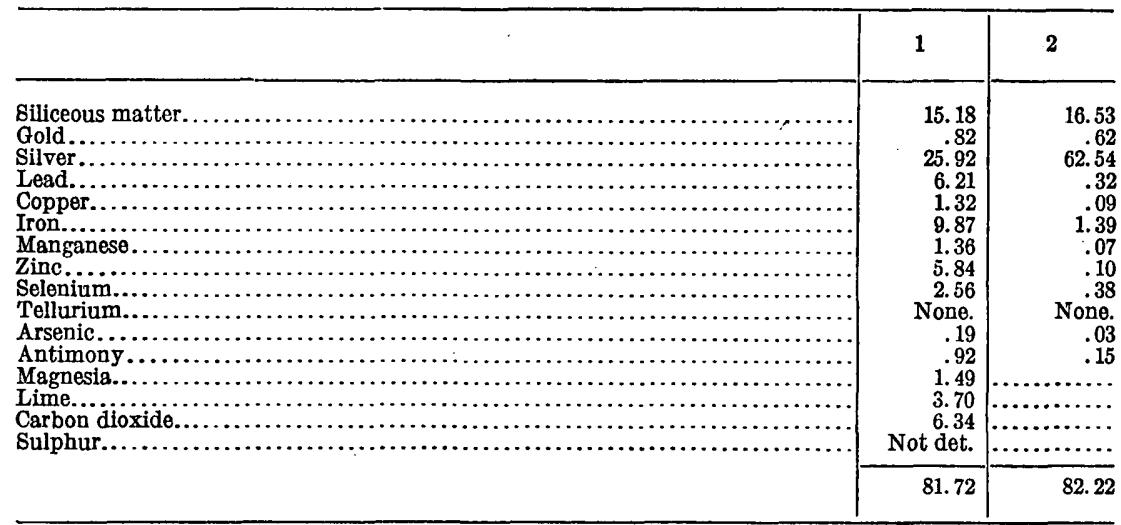

1. Concentrates of primary sulphide ore from Montana Tonopah mine.

2. Oxidized ore from Valley View vein.

Discussing the composition of the primary and secondary ores shown by the analyses, Spurr ${ }^{1}$ says:

Aside from the complex carbonate of lime, manganese, magnesia, and iron, the analysis of the primary sulphide ore indicates the presence of a large amount of silver sulphide-argentite. Antimonial sulphides of silver, polybasite, very likely stephanite, and smaller amounts of galena, blende, pyrite, and chalcopyrite are also indicated. Of very great interest is the presence of a considerable amount of selenium, which occurs, in part at least, as a silver selenide, and the absence of its usually closely associated element tellurium. The chemical form of the gold is yet uncertain.

It is fair to assume that the oxidized ore in its primary sulphide state may have had a composition somewhere relatively near that of the primary sulphide analyzed. The two analyses may then be compared with the object of perceiving the changes effected by oxidation. There is no element which can be considered as having remained quantitatively unaffected during oxidation, so that merely the large relations can be glanced at. All the metals except silver and perhaps gold are present in the oxidized ore in much diminished proportions. The lead, copper, and zinc are present in small quantities. The manganese is now in the form of oxide, but very little remains; the iron is in the form of oxide, with some residual or secondary pyrite. There is much less gold in proportion to silver in the oxidized ore than in the sulphide ore; but this may be fortuitous and depend on the specimen selected. More than half the silver is in the form of sulphide, and from the very small quantity of arsenic and antimony present this portion must be nearly all in the form of argentite. The antimonial silver sulphide is very probably pyrargyrite (ruby silver), judging from microscopic observations. It is noteworthy that antimony and arsenic are present in the same proportions to one another in both analyses. There is less than a third as much selenium in the oxidized ore as in the sulphide ore, but the discrepancy is not so great as in the case of lead, copper, manganese, zinc, arsenic, and antimony; and this selenium seems to be still in the form of a silver selenide.

Therefore it is probable that during the process of oxidation the primary carbonates were attacked by surface waters and the lime and magnesia, together with most of the iron and manganese, removed in solution. Some of the iron and manganese remain as oxides. No important change in the amount of gold and silver is proved. The argentite has largely remained unaltered, but the polybasite (and stephanite if 
present) has probably been attacked, and much of the silver selenide. Part of this silver has been reprecipitated with little change of position as secondary argentite, not distinguishable from the primary argentite, while a large portion has been altered to chloride by the action of chlorine contained in the shallow underground waters. Most of the arsenic and antimony in the original polybasite and stephanite has been removed in solution; the rest goes to form the secondary sulphide pyrargyrite, as indicated by numerous field observations. The pyrite and the chalcopyrite have been attacked. Most of the iron in these sulphides has been removed; a small part remains as oxide, or rarely as residual or secondary pyrite. Nearly all the copper has been removed, a little remaining in the probable form of oxide.

At Cripple Creek, as noted by Lindgren and Ransome, ${ }^{1}$ the original vein structure is destroyed by thorough oxidizing decomposition. In some sheeted lodes having many small parallel fissures and joints these openings become closed or effaced and the lode appears as a homogeneous brown, soft mass. In other places a central seam is retained and appears as a streak of soft, more or less impure kaolin; in still other places a central seam is filled with white compact alunite, more rarely by jasperoid or opaline silica. Crusts of comb quartz, if originally present, lie included in the clayey seams, but neither the original fluorite nor the carbonates are ordinarily preserved. Very rich oxidized ore fills the central cavities of some lodes like a thick brown mud and easily flows out when the vein is opened.

These writers say: ${ }^{2}$

In general oxidation tends to transform sulphides, sulphosalts, and tellurides to oxygen salts and native metals, both of which may, under certain circumstances, be further changed or carried away by surface waters. The silicates in the veins are changed to a few minerals most stable under atmospheric influences-that is, kaolin, quartz, manganese dioxide, and limonite. The carbonates of the earthy metals are carried away in solution, while those of manganese and iron are changed to oxides. As waters of acid reaction, frequently containing free sulphuric acid, prevail during oxidation of vein deposits, original quartz will not be attacked. New silica, generally hydrated, may be deposited by solutions derived from the decomposition of the silicates.

The processes are more difficult to follow and to establish by means of analyses than those due to primary vein formation, for it seems to be a characteristic feature of oxidation to segregate the new minerals in larger masses and thus produce a less homogeneous product; this is no doubt due to the energetic action of oxygen and of the acids set free, as well as to the increasing mobility of substance near the surface. Oxidation tends to thorough change of composition and also to obliteration of structure of the original rock or vein.

Of the metallic minerals the tellurides form the most important division. The bond between the tellurium and the gold is not a strong one, and direct oxidation very easily produces residual pseudomorphs of free gold and tellurium dioxide (the mineral tellurite), which in presence of iron oxides easily changes to various tellurites such as the yellowish-green emmonsite. In the Bonanza King Inde of the Midget mine occur veinlets of pyrite with tellurides. Within 30 or 40 feet of the surface

1 Lindgren, Waldemar, and Ransome, F. L., Geology and gold deposits of the Cripple Creek district, Colorado: Prof. Paper U. S. Geol. Survey No. 54, 1906, p. 199.

2 Idem, pp. 199-200.

$72293^{\circ}-$ Bull. $529-13-6$ 
oxidation has changed the tellurides to specks of native gold, while pyrite remains practically unaltered. The tellurides in fissures and joints, which form the most common mode of occurrence, will be most easily oxidized, while those occurring as metasomatic products in the rocks are not so readily reached by the surface waters.

Galena and zinc blende change to lead sulphate and zinc silicate, which may remain or even be somewhat concentrated in the altered mass. Molybdenite oxidizes very readily to yellow and blue molybdite and ilsemannite, products that do not seem to be easily carried away. Tetrahedrite yields various forms of oxidized copper oompounds which, as usual, show considerable mobility. No oxidized products containing antimony have been recognized. The fluorite on exposure to oxidation loses its deep-purple color and becomes disintegrated. Eventually a part of it is dissolved in surface waters.

The following table shows the results of analyses of unoxidized ore from- the Moose mine (column 1) and the oxidized portion of the same specimen (column 2). The specimens were analyzed by F. C. Knight and have been described by Richard Pearce. ${ }^{1}$ Column 3 shows an analysis by W. F. Hillebrand of wholly oxidized ore from the 100-foot level of Stratton's Independence mine.

Analyses of fresh and oxidized ores from Cripple Creek, Colo.

\begin{tabular}{|c|c|c|c|}
\hline & 1 & $2^{\circ}$ & 3 \\
\hline 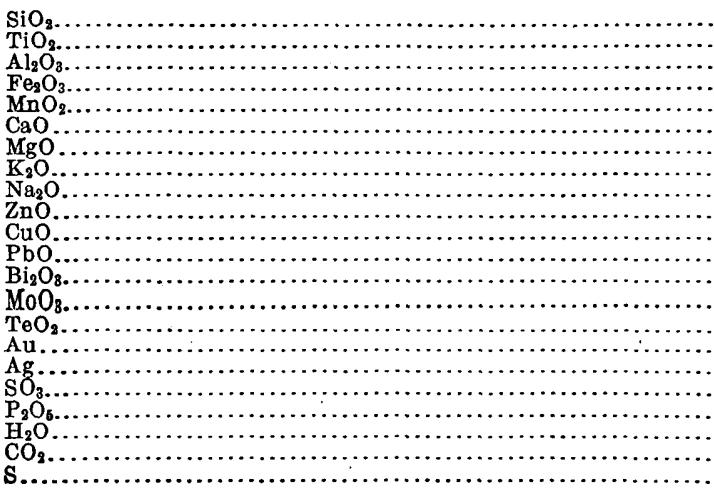 & 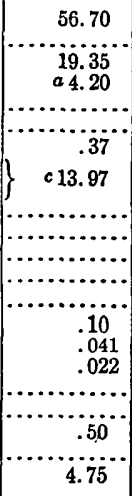 & 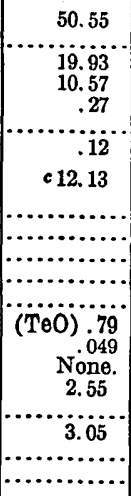 & $\begin{array}{r}54.45 \\
.80 \\
14.45 \\
a 9.94 \\
\text { b } 1.71 \\
1.14 \\
.48 \\
9.96 \\
.41 \\
d .53 \\
.03 \\
.18 \\
.0025 \\
.008 \\
.19 \\
.52 \\
.02 \\
.10 \\
.50 \\
\text { Not est. } \\
\text { Trace. } \\
\ldots \ldots . .\end{array}$ \\
\hline & 100 & 100.00 & e95. 4205 \\
\hline
\end{tabular}

$a$ Both $\mathrm{Fe}_{2} \mathrm{O}_{3}$ and $\mathrm{FeO}$ present. $b$ Both $\mathrm{MnO}_{2}$ and $\mathrm{MnO}$ present. c By difference.

\section{Of these analyses Lindgren and Ransome ${ }^{2}$ say:}

From the analyses and from what is known about the normal composition of unoxidized ore the following conclusions may be drawn, although it is of course realized that much more analytical work would be necessary for an exhaustive treatment of this difficult subject.

\footnotetext{
1 Pearce, Richard, Further notes on Cripple Creek ores: Proc. Colorado Sci. Soc., vol. 5, 1896, pp.11-16.

? Lindgren, Waldemar, and Ransome, F. L., Geology and gold deposits of the Cripple Creek district, Colorado: Prof. Paper U. S. Geol. Survey No. 54, 1906, pp. 202-203.
} 
During oxidation the percentage of silica decreases moderately, probably by solution of silica set free during the decomposition of silicates. Alumina remains fairly constant, though it may locally concentrate to pure kaolin. The iron is apt to locally increase by concentration as limonite, though a part will be carried away as sulphate. Small amounts of lime and magnesia are probably leached from the rock, but the quantity is not greatly changed. Manganese is greatly concentrated, locally, on the seams of the rock. As to alkalies, the accumulation of potassium begun during the vein-forming process is continued or at least maintained during oxidation. Pyrite is converted into sulphuric acid and sulphates, and the percentage of sulphur is greatly decreased in the oxidized ore. Part of it remains as sulphate, but as there appears to have been no corresponding decrease of the bases it would seem likely that a considerable part of it was carried away as free acid. Little change is noted in the titanium, while phosphoric acid and zinc appear to have increased. The small quantities of other metals do not seem to differ notably from those observed in fresh vein material. An increase of water to 3 or 5 per cent is a natural consequence of the formation of kaolin and other hydrated salts; locally it may increase up to 14 per cent, which is the amount contained in pure kaolin.

Silver and tellurium are removed by oxidation, but in general gold has remained. It is not easy to demonstrate whether a slight enrichment has taken place or not. Lindgren and Ransome incline to the belief that the oxidized ores as a whole are somewhat richer than the corresponding telluride ore, but this difference may depend on the original unequal distribution of the gold.

RELATIVE RATE OF SOLUTION OF SEVERAL, SULPHIDES IN A REDUCING ENVIRONMENT.

When oxygen is present the process of solution is so intimately related to that of oxidation that their results can not be considered separately. The experiments of Wells on the solution of pyrrhotite, sphalerite, galena, chalcopyrite, and pyrite in dilute sulphuric acid were made in stoppered test tubes, and although no special precaution was taken to exclude atmospheric air, yet the excess of hydrogen sulphide generated in at least three of the experiments indicates a reducing environment. The minerals were attacked in the following order, determined by the amount of hydrogen sulphide generated from the three first named: Pyrrhotite, sphalerite, galena, chalcopyrite, and pyrite. This series does not agree closely with any of the others named above. Possibly the electric currents that may be generated when two of the minerals are in contact would modify the rate of solution, but it should not be supposed that the series obtained under reducing conditions in acid would be identical with the series obtained by Gottschalk and Buehler in distilled water with free access of air.

The series obtained from Wells's experiments may not apply everywhere, but geologic evidence indicates that it applies to some deposits. Thus, in the Morenci district, according to Lindgren, ${ }^{1}$ the

1 Lindgren, Waldemar, The copper deposits of the Clifton-Morenci district, Arizona: Prof. Paper U. S. Geol. Survey No. 43, 1905, p. 183. 
solutions that deposit chalcocite in the secondary sulphide zone appear not to attack pyrite as long as zinc blende is present. Pyrrhotite also is attacked more readily than pyrite in the chalcocite zone at Ducktown, Tenn. In some ore the pyrrhotite has been reduced to a powdery mass while pyrite remains fresh and untarnished.

\section{METASOMATIC REPLACEMENT OF PRIMARY SULPHIDES BY SECONDARY}

SULPHIDES AND RELATIONS INDICATED BY 'SCHUERMANN'S SERIES.

As already stated, the series of Schuermann does not agree exactly with the solubilities of all the sulphides involved; but if comparatively unimportant metals, such as arsenic, antimony, cobalt, and bismuth, are eliminated the series is almost the same as that indicated by the molar solubilities of the sulphides as determined by Weigel. The positions of zinc sulphide and iron sulphide are reversed, but according to Weigel the molar solubilities of these are almost the same. As Schuermann himself observed, the farther apart in the series any two sulphides are the more nearly complete is the replacement.

In the processes of sulphide enrichment the primary sulphides are commonly replaced pseudomorphously by the secondary sulphides. Eliminating the relatively unimportant sulphides, such as those of cadmium and bismuth, and the sulphides of arsenic and antimony, which generally enter into composition with more than one others element to make the more complex secondary minerals, Schuermann's series (and Weigel's series, except zinc sulphide) is as follows: Mercury, silver, copper, lead, zinc, iron. In the table below, for convenience in inspection, the metals are placed in order of increasing solubilities of their sulphides in water, the more soluble sulphides being placed to the right of and below the less soluble ones.

Metasomatic replacement of several sulphides.

[In the order of Schuermann's series.]

\begin{tabular}{|c|c|c|c|c|c|}
\hline Mercury. & Silver. & Copper. & Lead. & Zinc. & Iron. \\
\hline \multicolumn{6}{|l|}{ Mercury. } \\
\hline Silver. & & $?$ & On PbS. & On $\mathrm{ZnS}$. & On $\mathrm{FeS}_{2}$. \\
\hline Copper. & & & $\begin{array}{l}\text { Metaso- } \\
\text { matic. }\end{array}$ & $\begin{array}{l}\text { Pseudo- } \\
\text { morphic. }\end{array}$ & $\begin{array}{l}\text { Pseudo- } \\
\text { morphic. }\end{array}$ \\
\hline Lead. & & & & On $\mathrm{ZnS}$. & On $\mathrm{FeS}_{2}$. \\
\hline Zinc. & & & & & $\begin{array}{l}\text { "Drives, } \\
\text { out iron." }\end{array}$ \\
\hline Iron. & & & & & \\
\hline
\end{tabular}


According to Schuermann's series it might be supposed that mercury sulphide would replace the sulphides of silver, copper; lead, zinc, and iron; that silver sulphide would replace the sulphides of copper, lead, zinc, and iron; that copper sulphide would replace the sulphides of lead, zinc, and iron; and so on.

The search for well-authenticated examples to fill in the several blocks in the table has been only partly successful. It would hardly be supposed that mercury sulphide would replace extensively the more soluble sulphides of other metals, for the solutions that transport the metals are, as already stated, sulphate solutions, and mercury sulphate has exceedingly low solubility. Moreover, mercury is driven out of combination by several metals and tends to form the native metal and the chloride. Secondary cinnabar is not unknown, however, in the oxidized zone. Silver dissolves in dilute sulphuric acid solutions in the presence of ferric sulphate, and at depth its sulphide is precipitated on those of lead, zinc, and iron. Hintze ${ }^{1}$ mentions pseudomorphs of argentite after proustite, stephanite, and pyrargyrite, but no examples of pseudomorphs of argentite after sphalerite, galena, or pyrite are available. The occurrences of secondary argentite are generally described as incrustations on the primary sulphides or as veinlets cutting them. Secondary chalcocite frequently contains silver which is disseminated through and doubtless contemporaneous with the copper sulphide, but the nature of the silver mineral is uncertain. The precipitation of silver sulphide at the expense of sphalerite has recently been emphasized by Irving and Bancroft ${ }^{2}$ in their discussion of secondary processes of enrichment of silver ores at Lake City, Colo. In view of the fact that copper sulphide is highly stable in acid solutions in the absence of an oxidizing agent it is not remarkable that the replacement of copper sulphides by silver sulphides is not common in the deeper zones.

Copper is much more abundant in its deposits than silver and the nature of its changes are more easily recognized. Long ago it was pointed out by Genth ${ }^{3}$ that copper sulphide replaces galena in deposits at Ducktown, Tenn., and B. S. Butler found examples of covellite replacing galena in the San Francisco district, Utah. As stated above, Lindgren has shown that copper sulphide replaces sphalerite at Morenci, and Butler found exceptionally clear examples of the replacement of zinc sulphide by covellite in the San Francisco district. It is said that copper sulphide replaces sphalerite at Butte, Mont., and without much doubt similar replacement is common in many mineral deposits. Examples of the pseudomorphous replacement

1 Hintze, Carl, Handbuch der Mineralogie, vol. 1, p. 442.

2 Irving, J. D., and Bancroft, Howland, Geology and ore deposits near Lake City, Colo.: Bull. U. S. Geol. Survey No. 478, 1911, pp. 64-65.

${ }^{8}$ Genth, F. A., Contributions to mineralogy: Am. Jour. Sci., 2d ser., vol. 33, 1862, p. 194. 
of pyrite by copper sulphide are well established and numerous, this method being the most common mode of origin of secondary copper sulphide ores. Some examples are enumerated on page 104. Although there are well-authenticated examples of sulphide enrichment of lead deposits, the pseudomorphs of galena after zinc and iron sulphides are not common. Hintze ${ }^{1}$ notes one replacement pseudomorphous after sphalerite and one after arsenopyrite. Statements are made that lead has driven iron or zinc out of its sulphide combinations, but lode ores afford surprisingly few examples of pseudomorphous replacements of sphalerite or pyrite. Possibly the strong tendency of galena to assume its own crystal form has obscured its pseudomorphic replacement of other minerals.

It has frequently been stated that zinc sulphide has been precipitated at the expense of iron sulphide and that zinc has driven iron out of its sulphide combination, but no examples of the pseudomorphous replacement of pyrite or marcasite by zinc blende are available. On the other hand Hintze ${ }^{2}$ notes a pseudomorph of marcasite after zinc blende.

It would not be supposed that under the usual conditions of concentration in the secondary sulphide zone a sulphide that appears to the right of the serrate line in the table on page 84 would replace one to the left of it on the same line. Thus the copper sulphides would not be replaced by lead sulphide or zinc sulphide, and so on. Some examples, however, do not agree with the relations indicated in this series, ${ }^{3}$ for there are pseudomorphs of pyrite after chalcopyrite, arsenopyrite, argentite; stephanite, polybasite, ruby silver, and tetrahedrite, and pseudomorphs of marcasite after pyrrhotite, pyrite, galena, argentite, sternbergite, stephanite, polybasite, miargyrite, bournonite, chalcopyrite, zinc blende, and other minerals.

The conditions that exist where the pseudomorphs are formed at the expense of the less soluble sulphide can not be stated. It would not be supposed that in cold acid solutions, under conditions that prevail in secondary sulphide zones the more soluble sulphides would be fixed at the expense of less soluble sulphides unless the metal entering into the composition of the more soluble sulphide were present in very high concentration. Probably some of the pseudomorphs mentioned above were formed in alkaline solutions or possibly at high temperatures, and the effect of increased temperature on the solubilities of the sulphides is unknown. It should be noted, however, that the secondary replacements that are clearly of great economic significance are such as would be expected from the relations indicated by the Schuermann series.

1 Hintze, Carl, Handbuch der Mineralogie, vol. 1, p. 481.

3 Idem, p. 820.

Idem, pp. 722 and 821. 


\section{SOURCE OF THE SULPHOR OF SECONDARY SULPHIDES AND GENERATION OF HYDROGEN SULPHIDE.}

The acid sulphate solutions that carry the metals downward from the oxidized zone to a reducing environment can not be regarded as an adequate source of sulphur for the secondary sulphides. Sulphides are almost unknown in mine waters, and in the presence of air hydrogen sulphide or any dissolved metallic sulphide would be oxidized to sulphate. In only two of the 37 analyses on pages 60-63 is sulphur reported-about 1 part per million in the alkaline water of the Federal Loan mine, Nevada City, Cal. (No. 27), and in an alkaline water from Butte, Mont. (No. 2). Traces of thiosulphate, probably due to oxidation after bottling, were noted in Nevada City samples $(27,28)$. Both of these were samples of alkaline solutions obtained from reducing environment.

The sulphate radicle, once formed, is exceedingly stable. It may be broken up by heat, but probably not at temperatures that exist under conditions of superficial alteration. Certain bacteria break up gypsum and other stable sulphates and liberate hydrogen sulphide, but these bacteria can hardly be regarded as an important agency for the generation of hydrogen sulphide, for it is doubtful whether they could survive the presence of copper and other salts, which most of these underground mineral waters carry. It is said that carbon may reduce the sulphate radicle to sulphide, but this statement has not been confirmed experimentally. Organic material, though it has been recognized in some mine waters, is not reported in many of the samples that were taken in glass-stoppered bottles and could have little or no part in the concentration of most lode ores. The only apparent adequate source of the sulphur that combines with the metals to form the secondary sulphides lies in the older sulphides. Where these sulphides are replaced pseudomorphously by secondary sulphides the sulphur has evidently remained in place, and in general the pseudomorphous replacements are attended by loss rather than by gain of sulphur.

As already stated, some of the secondary sulphide ore is found in cracks that cut the older sulphides. In some of these cracks the secondary minerals have replaced an older veinlet of sulphide ore, but in others the ore has clearly been deposited in an open space, which indicates that both the metal and the sulphur that enter into combination to form the secondary sulphide have migrated to the point of deposition. In some districts even secondary chalcocite is known to form veinlets in the older sulphide ore, one of the bestexamples being afforded by deposits of the Virgilina district, North Carolina, reviewed on page 107. These relations, indicating a transfer of sulphur in some unoxidized form, together with experimental evidence showing that dilute acid in contact with several primary sulphides will generate 
hydrogen sulphide, strongly suggest hydrogen sulphide or alkaline sulphides as agents precipitating some secondary sulphides. In view of the fact that sulphur compounds other than sulphates are practically unknown in mine waters, this conclusion might be questioned, but it should be recalled that of the samples available all but two were taken in the presence of air and that these two and many others contain ferric sulphate, which readily decomposes hydrogen sulphide. Hydrogen sulphide is used up in many ways, so it is not surprising that it does not accumulate in the zones of alteration.

\section{PROCESSES OF SULPHIDE ENRICHMENT COMPARED WITH THE PROCESS EMPLOYED FOR SEPARATING THE METALS IN QUAL- ITATIVE CHEMICAL ANALYSIS.}

Although it has not been shown that hydrogen sulphide is actually generated by bringing acid sulphate into contact with pyrite or chalcopyrite, or that it is an intermediate product in processes of metasomatic replacement, yet Wells's experiments for producing hydrogen sulphide (p. 59) clearly indicate the power of various sulphides to reduce some solutions or to precipitate sulphides from soluble salts. Without much doubt the same laws of chemical equilibrium apply to both processes, for the mineral that evolves hydrogen sulphide most easily will precipitate a secondary metallic sulphide most readily and will reduce acid solutions of reducible salts most readily.

The method commonly employed in qualitative analysis for separating the metals is as follows: The solution of the metals is made acid with hydrochloric acid, which precipitates silver, lead, and univalent mercury as chlorides. Hydrogen sulphide is passed into the acid solution and precipitates sulphides of lead, bismuth, copper, arsenic, antimony, tin, and bivalent mercury. The filtrate is made alkaline, generally with ammonium hydroxide, and then ammonium sulphide is added, which precipitates the sulphides of iron, manganese, nickel, cobalt, and zinc, also aluminum hydroxide. A review of this procedure may throw light on some of the natural processes of alteration and sulphide enrichment. Mine waters in the oxidized zonethe zone of solution-are acid and generally contain some chlorides. Silver chloride (cerargyrite), mercurous chloride (calomel), or lead chloride or chlorophosphate (pyromorphite) may be fixed in the oxidized zones of deposits carrying the metals indicated, but as chlorides are in general not abundant in mine waters, and as the chlorides named above are themselves somewhat soluble, some of the silver, lead, or mercury may be carried downward by the acid sulphate solutions. Hydrogen sulphide, which, as already stated, is generated by the action of dilute acid sulphate waters on some sulphides, will precipitate from acid solutions arsenic, antimony, tin, bismuth, copper, cadmium, mercury, lead, silver, and gold. These 
metals may therefore be precipitated as sulphides before the solution has become less acid. Thus the sulphides of copper, lead, and silver, for example, may be formed at or near the water level, or, in the absence of a water level, in the upper part of the zone of reduction. As the solutions descend they tend to become neutral and ultimately alkaline. When the solutions have lost acidity, sulphides of zinc, iron, and some other metals may be precipitated.

The analogy of the process of separation employed in qualitative analysis is not complete, however, for sulphide enrichment takes place in moving solutions and in solutions probably more dilute; the changes from acid solutions to neutral or alkaline solutions are gradual, especially in deposits not containing minerals that react readily with the solutions, like soluble carbonates and pyrrhotite.

Another relation should be emphasized: Although zinc sulphide is - not precipitated by hydrogen sulphide in the moderately acid solution used in the laboratory, it is precipitated in solutions of very feeble acidity. Thus zinc sulphide may be precipitated from a solution of acetic acid. Iron sulphide is less readily precipitated in acid than zinc súlphide. There is not much geologic evidence that either iron or zinc sulphide is precipitated extensively from cold descending acid sulphate solutions which traverse lode ores in igneous or other noncalcareous rocks. In such rocks the descending waters probably remain acid to moderately great depths, for the acid waters do not react on silicates so rapidly as on lime carbonate. These conditions would delay the deposition of secondary iron and zinc sulphides. There is some evidence that secondary chalcopyrite, pyrite, and sphalerite are formed in small cracks in the lower parts of some secondary sulphide zones, but they are surely subordinate to secondary copper sulphides in most deposits in noncalcareous rocks. One is warranted in supposing that the precipitation of the iron and zinc sulphides can be brought about only by a nice adjustment of conditions; iron and zinc are not precipitated in solutions that are highly acid, and neutral solutions probably will not vigorously attack the primary sulphides. These relations appear to be in harmony with the geologic observations, which indicate that pyrite and sphalerite are not abundant sêcondary sulphides in many lode ores. Of the action of alkaline solutions under these conditions not much is known.

\section{DECREASE OF ACIDITY OF DESCENDING SULPHATE WATERS.}

In the discussion of the composition of mine waters of sulphide ore deposits it was stated that the waters of the shallow zones are generally acid waters. Moreover, there is considerable evidence that acidity decreases below the water level. Analyses of two samples of water taken from a column of water in the Callaway shaft at Ducktown, Tenn., indicate a decrease in acidity of more than 50 
per cent within a vertical distance downward of 37 feet. Some analyses from the Capote mine, of Cananea, Mexico, show also a neutralization of acid at comparatively shallow depths. At least eight other samples, all except one taken at considerable depths, are alkaline. The conclusion is warranted, therefore, that acid solutions descending through sulphide ores decrease in acidity where oxygen is excluded; later they become neutral, and ultimately alkaline. The geologic data are completely in harmony with this conclusion, for there is abundant evidence that descending acid waters attack alkaline or alkaline-earth silicates and alkaline-earth carbonates; acid reacting with feldspars or sericite forms kaolin, and these reactions are attended by the solution of alkalies or alkaline earths as sulphates. Where limestone is attacked decrease in acidity may be attended by precipitation of gypsum.

There are reversals of these processes, it is true, for, according to Stokes, the precipitation of chalcocite is attended by the liberation of sulphuric acid. This acid, however, would soon be neutralized by reactions on silicates and carbonates and could not accumulate permanently. That it is so neutralized is indicated by the common association of secondary copper ore with kaolin or gypsum.

\section{CHANGES IN THE STATE OF OXIDATION OF DESCENDING ACID SULPHATE SOLUTIONS.}

The acidity of descending sulphate waters decreases below a certain depth, and because air is excluded the state of oxidation of the solutions likewise decreases. The degree of oxidation of iron, which is generally abundant in mine waters, affords a useful index to the state of oxidation of the solutions. The waters that pass downward from the oxidizing zone carry iron mainly in the ferric state. They may carry also some dissolved oxygen, but not much, for, according to Winkler, at atmospheric pressure and at $16.87^{\circ}$ a liter of water can dissolve but 6.84 cubic centimeters of oxygen. Underground waters are, moreover, seldom saturated with oxygen.

Dilute acid sulphate, which reacts on certain sulphides of iron, zinc, and lead; will under some conditions release hydrogen sulphide, which is available (1) for reduction of the oxygen in the water, (2) for reduction of ferric to ferrous sulphate, or (3) for the precipitation of copper or other sulphides which may be held in sulphate solution.

The reduction of the oxygen in the water will probably take place before the copper sulphide is precipitated, since axygen tends to inhibit the precipitation of copper sulphide. It is probable also that the oxygen of the solution is reduced before ferric sulphate is

1 Hempel, Walther, Gasanalytische Methoden, 1900, pp. 129-130. 
attacked, although both reactions may go on together. Assuming the presence of $\mathrm{H}_{2} \mathrm{~S}$, we may state the reactions as follows:

(1) $\mathrm{H}_{2} \mathrm{~S}+\mathrm{O}=\mathrm{H}_{2} \mathrm{O}+\mathrm{S}$.

(2) $\mathrm{Fe}_{2}\left(\mathrm{SO}_{4}\right)_{3}+\mathrm{H}_{2} \mathrm{~S}=2 \mathrm{FeSO}_{4}+\mathrm{H}_{2} \mathrm{SO}_{4}+\mathrm{S}$.

(3) $\quad \mathrm{H}_{2} \mathrm{~S}+\mathrm{CuSO}_{4}=\mathrm{CuS}+\mathrm{H}_{2} \mathrm{SO}_{4}$.

$\mathrm{CuS}+\mathrm{CuSO}_{4}+\mathrm{H}_{2} \mathrm{~S}=\mathrm{Cu}_{2} \mathrm{~S}+\mathrm{H}_{2} \mathrm{SO}_{4}+\mathrm{S}$.

If oxygen is present the reaction may go on as indicated by (1); if ferric sulphate is present, equation (2) would be possible; with neither oxygen nor ferric sulphate in the solution, equations (3) are possible.

\section{RATE AT WHICH HYDROGEN SULPHIDE IS GENERATED FROM SEVERAI, PRIMARY SULPHIDES BY COLD DILUTE ACID SUL- PHATE WATERS.}

As shown by experiments made by R. C. Wells (p. 59), cold dilute acid sulphate solutions attack several metallic sulphides and generate hydrogen sulphide. With equal surfaces exposed, such solutions in these experiments set hydrogen sulphide free at least four times as rapidly from zinc blende as from pyrite or chalcopyrite, and about twenty-five times as rapidly from pyrrhotite as from zinc blende. With pyrite and chalcopyrite the amount of hydrogen sulphide generated is small and the quantities determined may represent the end points of titration, for hydrogen sulphide was not identified as a product of the reaction. Doubtless sphalerite containing considerable iron sulphide will react more readily with acid than pure zinc sulphide. The quantity of hydrogen sulphide generated with galena, sphalerite, and pyrrhotite was sufficiently great, perhaps, to give the results a quantitative value.

These experiments were carried on with pure minerals that had been carefully examined. Minerals so pure are seldom found in large bodies of sulphide ores, where the sulphides generally occur in more or less intimate association. Gottschalk and Buehler have recently shown that in such mixtures weak batteries are formed and that the oxidation and solution of the mineral with the lowest potential will be increased while the solution of the mineral which is higher in the series will be retarded. There is no reason to suppose that the order of solution in an oxidizing environment like that in which the experiments of Gottschalk and Buehler were carried on would correspond closely to the order of attack in a reducing environment like that which existed under the conditions of Mr. Wells's experiments. Yet the associations of the sulphides may affect the rate of their solution in the reducing zone also. Consequently the rate of attack of acid sulphate solutions on various sulphide ores in the reducing zone can not be accurately stated. Possibly each association is a problem in itself. Where one of the metallic sulphides greatly predominates, 
however, it should not be supposed that a high potential would greatly retard its attack by acid in the reducing environment which is assumed to exist where the secondary sulphides are precipitated.

The laboratory experiments and geologic observations indicate that pyrrhotite is attacked very readily by acidic solutions, at least where it constitutes a considerable part of the ore. The reaction with sphalerite was less rapid than with pyrrhotite but more rapid than with pyrite and chalcopyrite. Here, too, field observations support the conclusions based on the laboratory experiments available. Describing the chalcocitization of sphalerite at Morenci, Lindgren ${ }^{1}$ says: "Pyrite apparently does not precipitate $\mathrm{Cu}_{2} \mathrm{~S}$ or $\mathrm{CuS}$ while zinc blende is present." Weed notes also that sphalerite is present in some of the primary ores at Butte, but that it is absent in the enriched chalcocite ores. ${ }^{2}$ The latter, however, contain pyrite. In a recent paper by Irving and Bancroft ${ }^{3}$ on the deposits of Lake City, Colo., the precipitation of secondary minerals on sphalerite from downwardmoving sulphate solutions is emphasized.

The data available seem therefore to indicate that in a large number of deposits at least the action of dilute sulphuric acid in the absence of air on the following sulphides is probably in the same order as that indicated by the experiments of Mr. Wells, viz, (1) pyrrhotite, (2) zinc blende, (3) pyrite and chalcopyrite.

\section{COMPOSITION OF THE PRIMARY ORE AS A FACTOR DETERMINING THE VERTICAL EXTENT OF THE SECONDARY SULPHIDE ZONE.}

S. F. Emmons and others have emphasized the fact that the vertical extent of the secondary sulphide zone depends principally on the amount of fracturing of the primary ore body and the size, continuity, and character of the fractures. The course of such fractures determines the course of descending waters and the size, character, and continuity of open spaces control the rates at which the solutions descend.

In their descent the metal-bearing solutions react on the walls of the watercourses, and these reactions produce changes of chemical equilibria and deposition of certain metals. These changes depend not only on the rate at which the solutions descend but also on the chemical environment through which they pass. In limestone or in calcite gangue the downward migration of copper would be delayed at least temporarily by the formation of carbonates (see p. 98) and calcite would quickly drive gold from acid solutions in which it was held dissolved as chloride.

\footnotetext{
1 Lindgren, Waldemar, The copper deposits of the Clifton-Morenci district, Arizona: Prof. Paper U. S. Geol. Survey No. 43, 1905, p. 183.

I Weed, W. H., Geology and ore deposits of the Butte district, Montana: Prof. Paper U. S. Geol. Survey No. 74,1912, p. 78 .

${ }^{8}$ Irving, J. D., and Bancroft, Howland, Geology and ore deposits near Lake City, Colo.: Bull. U. S. Geol. Survey No. 478, 1911, pp. 64-65.
} 
As already stated, dilute acid sulphate waters dissolve some pyrrhotite more rapidly than sphalerite and some sphalerite more rapidly than pyrite and chalcopyrite. The action on pyrrhotite and sphalerite is attended by tho liberation of hydrogen sulphide, which precipitates several of the metals in acid solution. Under similar conditions, because the reaction is brought near to completion more quickly, the vertical extent of the zones of secondary ores should be less in primary ores which carry abundant pyrrhotite than in ores of pyrite and chalcopyrite which contain no pyrrhotite, and although such secondary zones might be richer they would not extend so deep.

The attack of acid sulphate solutions on sphalerite is probably less vigorous than on pyrrhotite but more vigorous than the action on pyrite and chalcopyrite; consequently deposits that carry sphalerite should have secondary zones which are not so extensive vertically as those of deposits that contain pyrite and chalcopyrite with neither sphalerite nor pyrrhotite. Briefly stated, the vertical extent of the secondary sulphide zones should vary inversely with the rate at which the descending acid sulphate solutions attack the primary sulphides.

The data at present available do not cover a wide range of conditions and combinations, and the relations above indicated may have but little quantitative value, because deposits and minerals are not equally permeable, postmineral fractures are not equally spaced, equal surfaces of the primary minerals are not exposed, all deposits have not been equally eroded, and the temperatures prevailing are not the same. But notwithstanding these differences in the physical environment and geologic history of the deposits in different mining districts, I believe that the secondary sulphide zones of many deposits show relationships that depend on the composition of the primary ore and that may be rationally explained when inspected in the light of these chemical relations.

Principal mineral combinations of three groups of copper deposits.

\begin{tabular}{|c|c|c|}
\hline $\begin{array}{l}1 \\
\text { Pyrrhotite ores with pyrite and } \\
\text { chalcopyrite, with or without } \\
\text { zinc blende. }\end{array}$ & $\begin{array}{l}\text { 2 } \\
\text { Pyritic ore with sphalerite and } \\
\text { chalcopyrite. and with little or } \\
\text { no pyrrhotite. }\end{array}$ & $\begin{array}{l}\text { Pyritic chalcopyrite ores, with } \\
\text { Pittle or no pyrrhotite or zine } \\
\text { blende. }\end{array}$ \\
\hline $\begin{array}{l}\text { Ducktown, Tenn. } \\
\text { Gossan lead, Va. and N. C. } \\
\text { Ely, Vt. } \\
\text { Santiago de Cuba. } \\
\text { Encampment, W yo. } \\
\text { Grants Pass, Oreg. } \\
\text { Bingham, Utah (in part). } \\
\text { Sudbury, Ontario. }\end{array}$ & $\begin{array}{l}\text { Morenci, Ariz. } \\
\text { Santa Rita, N. Mex. (in part). } \\
\text { Shasta County, Ca]. } \\
\text { Velardefia, Mexico. } \\
\text { Jerome, Ariz. } \\
\text { Cananea, Mexico. }\end{array}$ & $\begin{array}{l}\text { Butte, Mont. (in part). } \\
\text { Bisbee, Ariz. } \\
\text { Globe, Ariz. } \\
\text { Miami, Ariz. } \\
\text { Ray, Ariz. }\end{array}$ \\
\hline
\end{tabular}

In the foregoing table certain deposits have been so grouped that three classes of copper ores may be inspected to ascertain whether the secondary chalcocite zones have a greater vertical extent in pyrrhotite deposits, in sphalerite deposits, or in copper deposits 
that contain little or no sphalerite or pyrrhotite. Those in the first column contain considerable pyrrhotite; all except one of them are known to have comparatively shallow chalcocite zones; in general the lower limit of chalcocite is from 50 to 250 feet below the present surface. These deposits are said to be comparatively tight and relatively impervious to the downward migration of mineral waters; consequently they do not afford examples ideal for comparison. Nevertheless I can find no example of a deposit that carries abundant pyrrhotite in which secondary sulphides are shown to have been deposited at great depths.

On comparing the deposits of column 1 with those of column 3 it is clearly apparent that the chalcocite zones in the latter are of much greater vertical extent; indeed, they include the deepest chalcocite zones that have been developed. In several of the deposits of column 3 chalcocite extends to depths ranging from 1,000 to nearly 1,500 feet below the surface. It is found at still greater depths at Butte, Mont., but an increasing trend of opinion held by those most familiar with these deposits indicates that the chalcocite of the lower levels of the Butte mines is primary. In some of the deposits of Arizona the secondary zones are very extensive vertically owing to the great distance to the zone of saturation. Undoubtedly some of the deposits of column 3 are much more highly fractured than some of those of column 1, consequently these examples are likewise not ideal for comparison. Yet the fact that none of the deposits with deep chalcocite are known to carry appreciable pyrrhotite appears to be significant.

The deposits of column 2 have chalcocite zones which in general are of greater vertical extent than those of column 1 and less than those of column 3 , but possibly the differences are too slight to give the figures much significance. It is a fact familiar to all, however, that rich silver ores frequently give way in depth. to primary ores containing abundant sphalerite, the contact zone being at some places comparatively narrow.

From the comparison of the several groups of deposits investigated, it is concluded that with approximately similar temperature, rainfall, erosion, head, permeability, and other conditions, the vertical extent of the secondary sulphide zone depends principally on the character and extent of fracturing in the primary ore bodies, but the vertical distribution of the secondary sulphides shows a relation also to the mineral composition of the primary ore. In general, ores containing abundant pyrrhotite are not enriched to depths so great as those containing pyrite and chalcopyrite but little or no pyrrhotite. The influence of zinc blende and of a small proportion of pyrrhotite can not yet be positively stated. 


\section{SOME CHEMICAL RELATIONS AND MINERALS OF COPPER.}

PRINCIPAL COPPER MINERALS.

The names and the chemical composition of the principal copper minerals are given below:

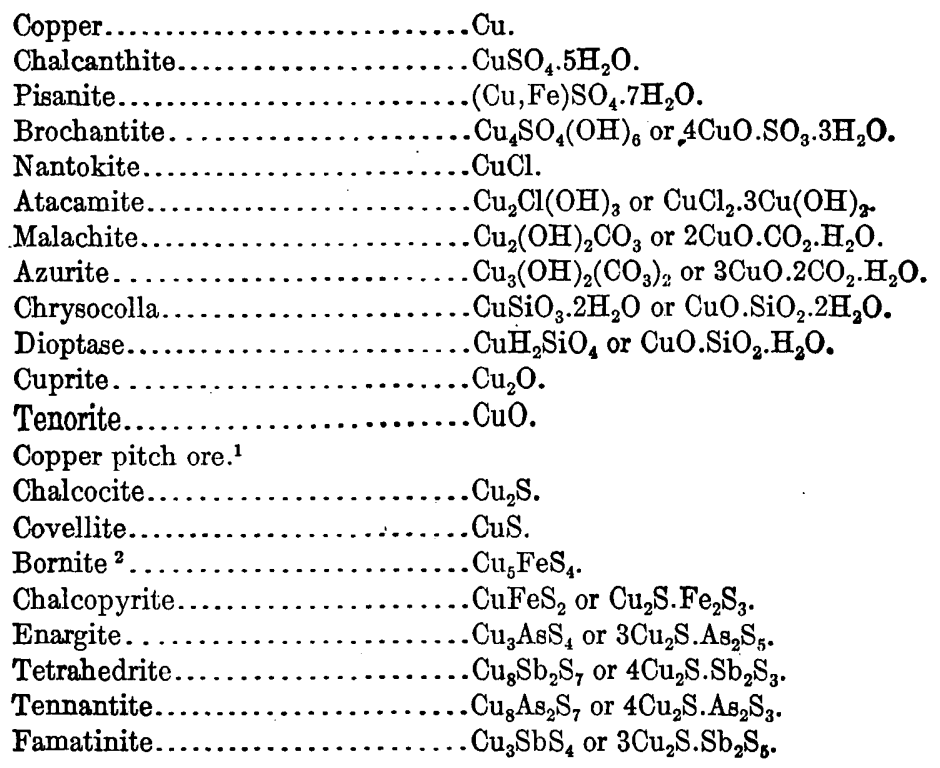

\section{SOLUBILITY OF SOME COPPER COMPOUNDS. ${ }^{3}$}

At $20^{\circ} \mathrm{C}$. a liter of water dissolves 172 grams $^{4} \mathrm{CuSO}_{4}$. At $20^{\circ} \mathrm{C}$. a liter of water dissolves $435 \mathrm{grams} \mathrm{CuCl}_{2}$. At $15^{\circ}$ to $16^{\circ} \mathrm{C}$. a liter of water containing 16.66 grams $\mathrm{HCl}$ dissolves 61.59 grams $\mathrm{CuCl}$.

\section{NATURE AND RELATIONS OF THE COPPER MINERALS.}

Copper, silver, and gold belong chemically to the same family; the three elements occupy exclusively the right side of the second column of the table of the periodic system and are somewhat closely affiliated. They stand apart as metals in the concentration of which the processes of sulphide enrichment are most clearly expressed. They are dissolved more or less readily in an oxidizing sulphate or chloride environment and are readily precipitated from acid waters by reactions in the sulphide environment where oxygen is excluded.

The mineral waters in the oxidizing zones of sulphide deposits are acid sulphate and ferric sulphate solutions. In the presence of oxygen such solutions dissolve copper very readily, and in contact with

\footnotetext{
1 A complex hydrated oxide.

2 Formula as established by B. J. Harrington (Am. Jour. Scl., 4th ser., vol. 16, 1903, p. 151). The older, commonly accepted formula is $\mathrm{Cu}_{3} \mathrm{FeS}_{3}$, also written $\mathrm{Cu}_{2} \mathrm{~S}$.CuS.FeS, or $3 \mathrm{Cu}_{2} \mathrm{~S} . \mathrm{Fe}_{2} \mathrm{~S}_{3}$.

Seidell, Atherton, Solubilities of Inorganic and organic substances, D. Van Nostrand Co., New York, 1907.

- For the solubility of hydrated copper sulphate see p. 53 .
} 
copper compounds such a system will contain also copper sulphate. The copper sulphate in solution reacts with carbonates or with acid carbonate in solution, precipitating copper carbonate. If chlorides are abundant, copper chlorides may form. Cupric chloride is readily soluble in water; cuprous chloride oxidizes to form oxychlorides. In moist countries both chlorides are unstable. In arid countries copper chloride may accumulate as atacamite. The sulphates chalcanthite and brochantite also may be precipitated, and the basic sulphate brochantite once formed is stable. The silicates of copper are probably formed by copper-bearing solutions reacting on silicic acid, which, as shown by analyses, is commonly dissolved in mine waters. Native copper, cuprite, and tenorite are formed by the reduction or oxidation of various copper compounds. Frequently such changes are pseudomorphic after an older mineral. All the copper minerals mentioned above are formed in the main in the oxidized or oxidizing zone, and in sulphide ore deposits their occurrence below the oxidizing zone is exceptional. None of them are known to form in depth by deposition from hot ascending alkaline solutions.

Below the oxidizing zone, where air is excluded, copper is precipitated as sulphides; chalcocite, covellite, bornite, chalcopyrite, and possibly some of the more complex antimony and arsenic compounds are formed by these processes. Precipitation may be brought about by chemical interchange with pyrite, chalcopyrite, pyrrhotite, zinc blende, galena, and probably with some other sulphides, the process being mainly metasomatic replacement. The copper sulphides are precipitated also by hydrogen sulphide, which may be generated by attack of acid sulphate solutions on several of these sulphides. At ordinary temperatures only $3.51 \times 10^{-6}$ mols of copper sulphide dissolves in a liter of water. In the reducing environment the copper sulphides are stable. They are insoluble even in hot concentrated acid sulphate solutions if a slight trace of hydrogen sulphide is present. ${ }^{1}$

Iron sulphide dissolves in acid, however, and it should not be supposed that the double sulphides of iron and copper would be precipitated from acid solutions which contained much copper. But as the solutions descend they lose acidity, and copper sulphide is precipitated at the expense of iron sulphide, the iron going into solution. A decrease in acidity, a decrease in copper, and an increase of iron in solution bring about a state of equilibrium which is increasingly favorable to the precipitation of double sulphides, such as chalcopyrite and bornite. ${ }^{2}$

In the oxidizing zone copper is much more soluble than gold, and, unlike gold, it may be dissolved in the absence of chlorides in sul-

1 Allen, E. T., oral communication.

2 Wells, R. C., The fractional precipitation of sulphides: Econ. Geology, vol. 5, 1910, pp. 12-13. 
phate solutions. Thus many deposits which contain both copper and gold show a distinct segregation of gold near the surface, while copper ores with subordinate gold are found in depth. The Highland Boy mine, at Bingham, Utah; the United Verde mine, at Jerome, Ariz.; and the Mount Morgan mine, in Australia, were operated first as gold mines and subsequently developed large bodies of copper-gold ores. In two of these mines the gold has probably not been dissolved to any great extent; in one, the Mount Morgan mine, the solution of gold is clearly indicated. Even where the conditions for the solution of gold are most favorable, however, it is probably precipitated mainly in the upper part of the chalcocite zone. It would not remain in solutions that contain much ferrous sulphate, and chalcocitization is doubtless attended by the generation of abundant ferrous sulphate.

Silver, like copper, dissolves somewhat readily in an acid sulphate environment, especially if ferric sulphate is present. Silver sulphide is not so soluble as copper sulphide, however (see p. 59), and in the presence of chlorides its downward migration is delayed by its precipitation as cerargyrite, or in the presence of ferrous sulphate or in contact with several sulphides and gangue minerals native silver is deposited. Some of the great copper lodes of Butte, Mont., were worked for silver to depths from 200 to 400 feet below the surface, where the deposits changed to rich copper ore. ${ }^{1}$ Like gold, silver would be driven from sulphate solutions in an environment where chalcocite forms. Its sulphide is even less soluble than copper sulphide and in depth would be precipitated as argentite. The rich narrow chalcocite zones at Ducktown, Tenn., contained considerable silver, although the primary pyrrhotite ore is only slightly argentiferous. In the north vein, Mass II, at Rio Tinto, Spain, ${ }^{2}$ both gold and silver were concentrated in a thin layer just above the zone of copper and iron sulphides.

As already stated, both gold and silver are precipitated from dilute solutions by ferrous sulphate, but copper sulphate and ferrous sulphate may exist in the same solution without precipitation of copper. It is reasonable to suppose that native silver as well as gold may be precipitated with chalcocite, but it is not so likely that under these conditions native copper and chalcocite would be precipitated simultaneously.

The rate at which certain sulphides react with acid to generate hydrogen sulphide and the tendency of certain ores to delay the downward migration of copper has already been discussed (p. 59).

\footnotetext{
1 Emmons, S. F., The secondary enrichment of ore deposits, in Pošepny, Franz, The genesis of ore deposits, 1902, pp. 442-443.

2 Vogt, J. H. L., Problems in the geology of ore deposits, in Pošepný, Franz, op. cit., p. 676. $72293^{\circ}-$ Bull. $529-13-7$
} 
The precipitation of gold and silver, if any were held in the copper sulphate solution, would be even more rapid.

Carbonates react with solutions of acid sulphate even more rapidly than pyrrhotite and likewise tend to delay the downward migration of copper, gold, and silver. If there is much lime carbonate in the gangue of the ore or in the wall rock, the downward migration of metallic sulphates may be checked or even inhibited. As stated by Bard, ${ }^{1}$ chalcocitization is seldom extensive in carbonate rocks, because the copper is precipitated as carbonate by reaction with calcite. To this there are some exceptions, and, appreciating these, Bard notes that the precipitation of some copper carbonate on the limestone may inhibit further action and insulate the passages from reaction with the descending solutions. Under such conditions copper sulphate could descend through carbonate rocks to considerable depths, where it could be precipitated by iron sulphide or by hydrogen sulphide if any were generated by the action of acid on sulphides or as copper carbonate by reactions with limestone.

In some districts, however, the primary mineralization of limestone is attended by extensive silicification. If carbonate has been removed, it would of course be no longer effective. The silicification of limestone at Bisbee, Ariz., has doubtless removed much of the carbonate in the region of the ore bodies.

A gangue of siderite, dolomite, or other carbonates would react with acid sulphate solutions and tend to neutralize them and to precipitate gold, silver, or copper, but the reaction would be somewhat less rapid than with calcite.

\section{OCCURRENCE OF THE COPPER MINERALS.}

Native copper occurs in the Lake Superior district and in zeolitic lodes elsewhere as the principal primary copper mineral. In the sulphide ores of the Cordillera of North America native copper is confined to the upper zone of the ore bodies and is clearly secondary. It is formed in many places by the reduction of cuprite and is frequently found, with copper oxides, directly above the zone of secondary chalcocite ores. The following reactions have been suggested but not proved:

$$
\begin{aligned}
& \mathrm{Cu}_{2} \mathrm{O}+2 \mathrm{FeSO}_{4}+\mathrm{H}_{2} \mathrm{SO}_{4}=2 \mathrm{Cu}+\mathrm{Fe}_{2}\left(\mathrm{SO}_{4}\right)_{3}+\mathrm{H}_{2} \mathrm{O} . \\
& \mathrm{Cu}_{2} \mathrm{O}+\mathrm{H}_{2} \mathrm{SO}_{4}=\mathrm{Cu}+\mathrm{CuSO}_{4}+\mathrm{H}_{2} \mathrm{O} .
\end{aligned}
$$

At Cananea, Mexico, at Cashin, Colo., and at many other places tabular masses of native copper cut the decomposed oxidized ore, suggesting the possibility that it has altered directly from chalcocite. At Morenci, Ariz., it is associated with cuprite, as a rule in the upper

1 Bard, D. C., Absence of secondary copper sulphide enrichment in calcite gangues: Econ. Geology, vol. 5,1910, p. 59 . 
limit of the chalcocite zone. In the Williams vein, Arizona Central mine, in this district, ${ }^{1} 200$ feet below the surface, a vein of solid copper was found in sericitized porphyry. The vein formed a sheet of copper, in places 8 inches thick, standing nearly vertical. It had in places a fibrous structure, perpendicular to the plane of the vein, such as occasionally is exhibited by the chalcocite seams, of which it is believed to be a pseudomorphic development. In one specimen, according to Lindgren, two sheets of copper were found separated by sooty chalcocite. In view of these relations it appears that copper may form directly from chalcocite without the intermediary stage of oxidation to cuprite. Lindgren suggests this reaction:

$$
\mathrm{Cu}_{2} \mathrm{~S}+3 \mathrm{Fe}_{2}\left(\mathrm{SO}_{4}\right)_{3}+4 \mathrm{H}_{2} \mathrm{O}=2 \mathrm{Cu}+6 \mathrm{FeSO}_{4}+4 \mathrm{H}_{2} \mathrm{SO}_{4} \text {. }
$$

Native copper was abundant above the third level of the Copper Queen ore body at Bisbee, Ariz., but comparatively rare in the lower portions of the oxidized ores. ${ }^{2}$ In the Calumet \& Arizona mine, however, it is abundant on the 1,050-foot level. It occurs in part as incrustations of chalcocite. At Bingham, Utah, ${ }^{3}$ it is rare but has been observed. Native copper is extensively developed in the upper zones of copper deposits at Santa Rita, N. Mex. In general it is abundant from 100 to 200 feet below the surface. According to Lindgren, Graton, and Gordon, it is probably an alteration product of sulphides, but the latter appear to have been deposited in part in open spaces in the porphyry rather than as replacements of pyrite. In this district and also in the copper deposits of Lake Superior native copper has been found as perfect pseudomorphs after hornblende. According to Yeates, ${ }^{5}$ native copper in Grant County, N. Mex., is pseudomorphous after azurite. Native copper is not abundant at Butte, Mont. ${ }^{\circ}$

In view of the fact that ferrous sulphate, a reducing agent, probably accumulates at depths at which chalcocite forms, one would suppose that native copper, which is a product of reduction, might be deposited under some conditions along with chalcocite; this association is not uncommon, but may be due to subsequent oxidation and partial reduction of chalcocite to native copper. At Ducktown, Tenn., according to report, when mines that had been closed during

${ }^{1}$ Lindgren, Waldemar, The copper deposits of the Clifton-Morenci district, Arizona: Prof. Paper U. S. Geol. Survey No. 43, 1905, p. 101.

2 Ransome, F. L., The geology and ore deposits of the Bisbee quadrangle, Arizona: Prof. Paper U. S. Geol. Survey No. 21, 1904, p. 120.

3 Boutwell, J. M., Economic geology of the Bingham mining district, Utah: Prof. Paper U. S. Geol. Survey No. 38, 1905, p. 110.

- Lindgren, Waldemar, Graton, L. C., and Gordon, C. H., The ore deposits of New Mexico: Prof. Paper U. S. Geol. Survey No. 68, 1910, p. 316.

- Yeates, W. S., Pseudomorphs of native copper after azurite, from Grant County, N. Mex.: Am. Jour. Sci., 3d ser., vol. 38, 1889, pp. 405-407.

- Weed, W. H., Geology and ore deposits of the Butte district, Montans: Prof. Paper U. S. Geol. Survey No. 74,1912 , p. 80. 
the Civil War were reopened masses of native copper were found hanging to some of the timbers. ${ }^{1}$

Chalcanthite, blue vitriol, $\mathrm{CuSO}_{4} \cdot 5 \mathrm{H}_{2} \mathrm{O}$, is frequently present in the oxidized zones as efflorescences or stalactites on open fissures, or as veinlets filling small crevices above the upper limit of the zone of secondary sulphides. At Ducktown, Tenn., it is abundant also in the chalcocite zone. It rarely forms far below the top of the chalcocite zone, except on surfaces of openings made by mining operations. Locally it is an ore of some importance. At Butte, Mont., according to Weed, ${ }^{2}$ it coats rock fragments in old stopes, in places so abundantly that it has been found profitable to collect it from time to time. In the Silverbow mine pure chalcanthite is so abundant as to almost fill some of the old drifts. Beautiful stalactites and shapes imitating organ pipes are developed. Weed states that copper sulphate is carried by the moisture of the atmosphere circulating in mine openings. ${ }^{3}$

Pisanite, $(\mathrm{CuFe}) \mathrm{SO}_{4} \cdot 7 \mathrm{H}_{2} \mathrm{O}$, is a rare sulphate of copper and iron. Large and beautiful specimens were found in copper deposits at Bingham, Utah. ${ }^{4}$ At Butte, Mont., stalactites occur, usually in deserted drifts. ${ }^{5}$

Brochantite, $\mathrm{H}_{6} \mathrm{Cu}_{4} \mathrm{SO}_{10}$, a basic sulphate of copper, has been identified at only a few places. It is of common occurrence in the ores of the Clifton-Morenci district, Arizona, where, according to Lindgren, ${ }^{6}$ it is intergrown with malachite, which effectively masks its presence in hand specimens. In the Shannon mine, near the surface, in porphyry, it constitutes a rich ore body. Ransome noted it also in sections from the oxidized zone at Bisbee, Ariz. In all its occurrences it is probably a deposit from oxidizing waters.

Sullivan ${ }^{7}$ obtained a substance of the composition of brochantite by treating silicates with copper sulphate solutions. Lindgren ${ }^{8}$ states that brochantite may form directly by the oxidation of chalcocite according to the following reaction:

$$
2 \mathrm{Cu}_{2} \mathrm{~S}+10 \mathrm{O}+4 \mathrm{H}_{2} \mathrm{O}=\mathrm{H}_{8} \mathrm{Cu}_{4} \mathrm{SO}_{10}+\mathrm{H}_{2} \mathrm{SO}_{4} \text {. }
$$

Atacamite and nantokite. - Atacamite, $\mathrm{CuCl}_{2} \cdot 3 \mathrm{Cu}(\mathrm{OH})_{2}$, the oxychloride of copper, and nantokite, $\mathrm{CuCl}$, cuprous chloride, are com-

1 Edwards, W. F., Discussion of papers by H. A. Lee, on "Gases in metalliferous mines": Proc. Colorado Sci. Soc., vol. 7, 1904, p. 183.

2 Weed, W.H., Geology and ore deposits of the Butte district, Montana: Prof. Paper U. S. Geol. Survey No. 74, 1912, p. 81.

3 Idem, p. 99.

- Boutwell, J. M., Economic geology of the Bingham mining district, Utah: Prof. Paper U. S. Geol. Survey No. 38, 1905, p. 111.

6 Weed, W. H., op. cit., p. 82.

${ }^{6}$ Lindgren, Waldemar, The copper deposits of the Clifton-Morenci district, Arizona: Prof. Paper U. S. Geol. Survey No. 43, 1905, p. 118.

${ }^{7}$ Sullivan, E. C., The interaction between minerals and water solutions: Bull. U. S. Geol. Survey No. 3i2, 1907, p. 61.

8 Op. cit, p. 188. 
paratively rare secondary copper minerals. They are probably formed in the oxidized zones, but on account of their solubility in natural waters they do not generally accumulate.

Since cuprous chloride is comparatively less soluble in water, it would be supposed that nantokite would be fixed more readily than the cupric salt atacamite. On exposure to the air, however, the cuprous chloride is oxidized to form atacamite. Such is said to be the genesis of some atacamite of Chile. In the United States the natural chlorides of copper are almost unknown.

Malachite, $(\mathrm{CuOH})_{2} \mathrm{CO}_{3}$, a basic cupric carbonate, is abundant in the oxidized zones of many cupriferous deposits and is most abundant in deposits that are inclosed in limestone. It was present in considerable quantity in the superficial portions of copper deposits at Bingham, Utah, ${ }^{1}$ where it occurs as globular masses and also as bands equivalent to parts of certain rock strata. It also forms envelopes about sulphides and oxides. In the Old Dominion mine at Globe, Ariz., according to Ransome, ${ }^{2}$ malachite is conspicuously developed as veinlets in quartzite and has locally replaced the quartzite. Malachite is present almost universally in the oxidized zones of sulphide deposits and in some of them it persists in the outcrop. Its association with limonite in the gossan has encouraged deep derelopment in many copper districts. It is unknown as a primary ore in deposits formed by thermal waters.

If copper sulphate waters should mingle with acid carbonate waters the following reaction ${ }^{3}$ would probably take place:

$$
2 \mathrm{CuSO}_{4}+2 \mathrm{H}_{2} \mathrm{Ca}\left(\mathrm{CO}_{3}\right)_{2}=\mathrm{CuCO}_{3} \cdot \mathrm{Cu}(\mathrm{OH})_{2}+2 \mathrm{CaSO}_{4}+3 \mathrm{CO}_{2}+\mathrm{H}_{2} \mathrm{O} \text {. }
$$

Acid waters attacking limestone would form malachite according to the following reaction:

$$
2 \mathrm{CuSO}_{4}+2 \mathrm{CaCO}_{3}+5 \mathrm{H}_{2} \mathrm{O}=\mathrm{CuCO}_{3} \cdot \mathrm{Cu}(\mathrm{OH})_{2}+2 \mathrm{CaSO}_{4} \cdot 2 \mathrm{H}_{2} \mathrm{O}+\mathrm{CO}_{2} \text {. }
$$

Solutions of iron sulphate and copper sulphate react with limestone and deposit limonite and malachite simultaneously.

Azurite, $2 \mathrm{CuCO}_{3} \cdot \mathrm{Cu}(\mathrm{OH})_{2}$, like malachite, is a basic cupric carbonate. So far as known, it is not formed by ascending thermal waters. It is very much less abundant than malachite, but in some deposits in limestone, as at Bisbee, Ariz., it is plentiful. Kemp ${ }^{3}$ suggests the following reaction with copper sulphate and acid carbonate solutions:

$$
3 \mathrm{CuSO}_{4}+3 \mathrm{H}_{2} \mathrm{Ca}\left(\mathrm{CO}_{3}\right)_{2}=2 \mathrm{CuCO}_{3} \cdot \mathrm{Cu}(\mathrm{OH})_{2}+3 \mathrm{CaSO}_{4}+4 \mathrm{CO}_{2}+2 \mathrm{H}_{2} \mathrm{O} \text {. }
$$

\footnotetext{
1 Boutwell, J. M., Economic geology of the Bingham mining district, Utah: Prof. Paper U. S. Geol. Survey No. 38, 1905, p. 107.

8 Ransome, F. L., Geology of the Globe copper district, Arizona: Prof. Paper U. S. Geol. Survey No. 12, 1903, p. 122.

${ }^{3}$ Kemp, J. F., Secondary enrichment in ore deposits of copper: Econ. Geology, vol. 1, 1906, p. 24.

4 Lindgren, Waldemar, The copper deposits of the Clifton-Morenci district, Arizona: Prof. Paper U. $\mathbf{S .}$ Geol. Survey No. 43, 1905, pp. 189-190.
} 
At Morenci it is frequently associated with kaolin $^{1}$ and is generally one of the last minerals to form.

In limestone azurite may be formed according to the following reaction:

$$
3 \mathrm{CuSO}_{4}+3 \mathrm{CaCO}_{3}+7 \mathrm{H}_{2} \mathrm{O}=2 \mathrm{CuCO}_{3} \cdot \mathrm{Cu}(\mathrm{OH})_{2}+3 \mathrm{CaSO}_{4} \cdot 2 \mathrm{H}_{2} \mathrm{O}+\mathrm{CO}_{2} \text {. }
$$

Chrysocolla, the bluish-green hydrous copper silicate $\mathrm{CuOH}_{4} \mathrm{SiO}_{4}$, forms rather abundantly in the outcrops and near the surface of some copper deposits; in others it is rare or absent. It is a common mineral also in the oxidized zone of some silver and gold mines. Although widely distributed in some lodes, it occurs at most places only in small bodies. It is frequently associated with malachite and azurite and is not known as a deposit of ascending hot waters. At Globe, Ariz., ${ }^{2}$ chrysocolla replaces dacitic tuff. In this district it is older than malachite where the two minerals are together and it forms at greater depth than malachite. It is an ore mineral in several other deposits of the Southwest, where it is mined with copper oxides and carbonates. At Bisbee it seems never to have been abundant, but in the Calumet \& Arizona mine it forms thin shells about kernels of cuprite, native copper, and brochantite and is in turn enveloped by malachite and calcite. ${ }^{3}$ At Butte, Mont., ${ }^{4}$ it is found in the country rock near the veins. At Cripple Creek $^{5}$ chrysocolla is an oxidation product of tetrahedrite.

There is no record of the synthesis of chrysocolla in the laboratory. Kemp ${ }^{6}$ has suggested that it results from gelatinizing silica and solutions of copper sulphate:

$$
\mathrm{CuSO}_{4}+\mathrm{H}_{2} \mathrm{Ca}\left(\mathrm{CO}_{3}\right)_{2}+\mathrm{H}_{4} \mathrm{SiO}_{4}=\mathrm{CuOH}_{4} \mathrm{SiO}_{4}+\mathrm{CaSO}_{4}+\mathrm{H}_{2} \mathrm{O}+2 \mathrm{CO}_{2} \text {. }
$$

It appears that the abundant carbonate is not uniformly a necessary condition for its genesis, since in the Morenci district, Arizona, ${ }^{7}$ it is more abundant in the ores in porphyry and in granite than in the ores in limestone. In some deposits in porphyry it is of commercial value. An interesting occurrence of highly auriferous chrysocolla is that of the Original Bullfrog mine in Nevada. If in the reaction suggested by Kemp ferrous acid carbonate were present in place of

1 Lindgren, Waldemar, The copper deposits of the Clifton-Morenci district, Arizona: Prof. Paper U. S. Geol. Survey No. 43, 1905, p. 118.

2 Ransome, F. L., Geology of the Globe copper district, Arizona: Prof. Paper U. S: Geol. Survey No. 12,1903, p. 123 .

${ }^{3}$ Ransome, F. L., The geology and ore deposits of the Bisbee quadrangle, Arizona: Prof. Paper U.8. Geol. Survey No. 21, 1904, p. 126.

4 Weed, W. H., Emmons, S. F., and Tower, G. W., Butte special folio (No. 38), Geol. Atlas U. S., U. S Geol. Survey, 1897, p. 6.

- Lindgren, Waldemar, and Ransome, F. L., Geology and gold deposits of the Cripple Creek district, Colorado: Prof. Paper U. S. Geol. Survey No. 54, 1906, p. 129.

6 Kemp, J. F., Secondary enrichment in ore deposits of copper: Econ. Geology, vol. 1, 1906, pp. 24-25.

7 Lindgren, Waldemar, The copper deposits of the Clifton-Morenci district, Ariz ona: Prof. Paper U. S. Geol. Survey No. 43, 1905, p. 112. 
that of lime, ferrous sulphate would form instead of calciúm sulphate. Minute quantities of ferrous sulphate drive gold from solutions in which it is dissolved as chloride. Possibly the free gold of chrysocolla was precipitated by ferrous sulphate.

Dioptase, $\mathrm{H}_{2} \mathrm{CuSiO}_{4}$, or $\mathrm{H}_{2} \mathrm{O}$.CuO. $\mathrm{SiO}_{2}$, like chrysocolla, is a secondary copper silicate. It is characteristically formed in the zone of oxidation and is unknown as a deposit from hot ascending waters. It is known in only a few places in the United States, among them Morenci, Ariz., ${ }^{1}$ where it is associated with chrysocolla in limestone.

Cuprite, $\mathrm{Cu}_{2} \mathrm{O}$, is a common mineral of the oxidized zones of deposits of copper sulphides and is probably secondary in all its occurrences. It is an important ore mineral at Bisbee, Ariz., where, according to Ransome, ${ }^{2}$ it is found in an impure earthy condition mixed with limonite and ferruginous clays or in crystalline masses associated with native copper. The latter occurrence is particularly characteristic of the deeper oxidized zones in the vicinity of chalcocite and other sulphides. In the Calumet \& Arizona mine cuprite is found in large crystalline masses. On the 950-foot level it occurs in bunches in earthy ore, penetrated by dendritic masses of metallic copper and spotted with little vugs of acicular malachite. It is abundant at Morenci, Ariz., at Cananea, Sonora, and in other western districts. At Morenci, according to Lindgren, ${ }^{3}$ it occurs normally at the upper limit of the chalcocite zone as a product of decomposition of chalcocite. Similar relations are shown at Cananea. At Santa.Rita, N. Mex., abundant cuprite and native copper fill fissures in the oxidized zone and presumably are secondary in the main after chalcocite. At Butte, Mont., where it is sparingly developed and is not important commercially, ${ }^{4}$ it generally contains masses of native copper, the line of contact between them being indistinct. ${ }^{5}$ According to Boutwell ${ }^{\circ}$ cuprite is not. abundant at Bingham, Utah, but small grains covered with malachite were noted in brown altered limestone of the Commercial mine. Cuprite is present in the upper portion of the rich secondary ore at Ducktown, Tenn., and in other copper deposits of the southern Appalachians. The mode of its derivation from chalcocite is stated by Lindgren as follows: ${ }^{7}$

$$
2 \mathrm{Cu}_{2} \mathrm{~S}+\mathrm{O}=2 \mathrm{CuS}+\mathrm{Cu}_{2} \mathrm{O} .
$$

${ }^{1}$ Lindgren, Waldemar, The copper deposits of the Clifton-Morenci district, Arizona: Prof. Paper U. S. Geol. Survey No. 43, 1905, p. 111.

Ransome, F. L., The geology and ore deposits of the Bisbee quadrangle, Arizona: Prof. Paper U. S. Geol. Survey No. 21, 1904, p. 128.

s Lindgren, Waldemar, op. cit., p. 106.

4 Weed, W. H., Geology and ore deposits of the Butte district, Montana: Prof. Paper U. S. Geol. Survey No. 74,1912, p. 80 .

5 Weed, W. H., Emmons, S. F., and Tower, G. W., Butte special folio (No. 38), Geol. Atlas U. S., U. S. Geol. Survey, 1897, p. 6.

${ }^{6}$ Boutwell, J. M., Economic geology of the Bingham mining district, Utah: Prof. Paper U. S. Geol. Survey No. 38, 1905, p. 109.

? Lindgren, Waldemar, op. cit., p. 186. 
Lindgren considers it improbable that ferrous sulphate reduces cupric sulphate to precipitate cuprous oxide, since cupric sulphate and ferrous sulphate appear to mix in all proportions without reaction.

Tenorite, $\mathrm{CuO}$, the crystalline form of the black oxide of copper, is much less abundant than cuprite. The earthy, sooty variety, known as melaconite, is said to be present at Butte, Mont., where it is associated with cuprite and native copper and forms dark rims about cuprite. ${ }^{1}$ According to Boutwell ${ }^{2}$ scales of black copper oxide with metallic luster occur with chalcocite in ores of Bingham, Utah. At Bisbee ${ }^{3}$ melaconite is found in soft clayey ores on the 1,000 -foot level of the Lowell mine. Apparently it is now being deposited along with wad near the 850-foot level of the Calumet \& Arizona mine. At Ducktown, Tenn., much of the so-called black copper ore has proved to be sooty chalcocite.

Copper pitch ore is a secondary material of complex character and somewhat uncertain composition. A sample from the Detroit mine in the Morenci district, Arizona, analyzed by Hillebrand, showed oxides of copper, zinc, and manganese, with considerable water and silica. Material that is probably of a similar nature is found at Bisbee and at Courtland, Ariz., and on the Ida, Montgomery, and Amazon claims ${ }^{5}$ at Butte, Mont.

Chalcocite, $\mathrm{Cu}_{2} \mathrm{~S}$, copper glance, is economically the most important copper mineral. In 1906, according to Graton, ${ }^{8} 47$ per cent of the copper produced in the United States was derived from chalcocite ores. In most of its occurrences chalcocite is clearly of secondary origin, for it replaces other minerals metasomatically or occurs as veinlets in small cracks in the primary ore. Well-authenticated examples are known of its replacement of pyrite, zinc blende, and galena. In many deposits now worked in which chalcocite is the principal mineral exploration extends into the lower-grade primary sulphide ore, which generally consists of chalcopyrite, pyrite, and other minerals without chalcocite.

Examples indicating replacement of pyrite by chalcocite are numerous. At Morenci, Ariz., according to Lindgren, ${ }^{7}$ most of the ore bodies owe their origin to this process. Lindgren writes:

By chalcocitization the massive veins of pyrite become transformed into solid masses of black dull chalcocite, while the sericitized porphyry becomes filled with

\footnotetext{
1 Weed, W. H., Emmons, S. F., and Tower, G. W., Butte special folio (No. 38), Geol. Atlas U. S., U.S. Geol. Survey, 1897, p. 6.

${ }^{2}$ Boutwell, J. M., Economic geology of the Bingham mining district, Utah: Prof. Paper U. S. Geol. Survey No. 38, 1905, p. 109.

${ }^{3}$ Ransome, F. L., The geology and ore deposits of the Bisbee quadrangle, Arizona: Prof. Paper U. S. Geol. Survey No. 21, 1904, p. 128.

- Lindgren, Waldemar, The copper deposits of the Clifton-Morenci district, Arizona: Prof. Paper U. S. Geol. Survey No. 43, 1905, p. 114.

5 Weed, W. H., Geology and ore deposits of the Butte district, Montana: Prof. Paper U. S. Geol. Survey No. 74,1912, p. 81 .

${ }^{6}$ Graton, L. C., Copper: Mineral Resources U. S. for 1906, U. S. Geol. Survey, 1907, p. 410.

' Lindgren, Waldemar, op. cit., p. 185.
} 
grains and little seams of the same mineral. The first constitutes high-grade ores, the second the low-grade. A residue of pyrite, not yet acted upon, is nearly always present. Thus a vein of massive sooty material cutting the shale in the Montezuma mine contained 96 per cent $\mathrm{Cu}_{2} \mathrm{~S}$ and 2.4 per cent $\mathrm{FeS}_{2}$, and pyrite may be easily seen in nearly every specimen of low-grade porphyry ore. The pyrite first becomes coated with a black stain; in a more advanced stage the chalcocite penetrates the pyrite on cracks and fissures in all directions; finally it almost entirely replaces it. * * * Kaolin gouge always accompanies chalcocite when occurring as massive veins; in the chalcocitized porphyry the process is nearly always attended by a formation of a little brownish kaolin, together with microcrystalline quartz or more often chalcedony; these minerals encircle the pyrite or traverse the chalcocite as minute veinlets, distinctly later than the alteration of the porphyry to sericite and pyrite. Sericite does not form during chalcocitization; on the contrary, the kaolin is formed at the expense of that mineral. *** The transition from chalcocite to unaltered pyrite at the lower limit of the zone is remarkably sudden. Usually a change takes place within 25 feet, sometimes within 10 feet, from rich chalcocite ore to pyrite with one-half to 1 per cent copper. Chalcopyrite is rarely found as a secondary mineral but has been observed as small grains inclosed in chalcocite veinlets.

At Bingham, Utah, according to Boutwell, ${ }^{1}$ chalcocite incloses pyrite and chalcopyrite. At the Snowstorm and Park mines, in the Cœur d'Alene district, Idaho, chalcocite and bornite ore are disseminated in quartzite. At the Park mine chalcocite has formed on pyrite and chalcopyrite. ${ }^{2}$ In the Bisbee district, according to Ransome, chalcocite occurs as veinlets in and envelopes around grains of pyrite. Limestone altered to white claylike material is streaked with veinlets of chalcocite and speckled with native copper. Some solid, compact chalcocite is associated with bornite. ${ }^{3}$ Examples of replacement of pyrite by chalcocite could be multiplied to include occurrences from nearly every important district of copper sulphide ores in the United States.

In the copper deposits of Butte, Mont., which are perhaps the largest in the world, chalcocite is an important ore mineral. The bulk of the ore is altered "granite" with disseminated grains and veinlets of chalcocite intergrown with pyrite or replacing that mineral completely. Distinct crystals are rare. In this district the history of the vein formation is exceedingly involved, and at least three periods of mineralization are recognized. The great chalcocite bonanzas in the upper levels at Butte were regarded by S. F. Emmons, W. H. Weed, H. V. Winchell, and others as secondary, and no other interpretation appears to be warranted by their occurrence and relations. More recently, however, masses of ore containing chalcocite have been found as deep as 2,800 feet below the surface, and Reno

\footnotetext{
1 Boutwell, J. M., Economic geology of the Bingham mining district, Utah: Prof. Paper U. S. Geol. Survey No. 38, 1905, pp. 221-222.

2 Ransome, F. L., and Calkins, F. C., The geology and ore deposits of the Cœur d'Alene district, Idaho. Prof. Paper U. S. Geol. Survey No. 62, 1908, p. 91.

8 Ransome, F. L., The geology and ore deposits of the Bisbee quadrangle, Arizona: Prof. Paper U. S. Geol. Survey No. 21, 1904, pp. 123-124.
} 
Sales ${ }^{1}$ is of the opinion that a portion of the massive deep-seated chalcocite at Butte is of primary origin. The studies of polished surfaces examined microscopically by Simpson ${ }^{2}$ of ore from the 2,000-foot level showed massive pyrite surrounding, in the plane of the section, small and apparently isolated flakes of chalcocite. A veinlet of ore from the 1,000-foot level of the Leonard mine shows isolated idiomorphic crystals of quartz and pyrite surrounded by chalcocite. ${ }^{3}$ It is not easy to account for secondary chalcocite in such surroundings.

L. C. Graton noted that chalcocite is found as deep as 970 feet in the Bully Hill mine, Shasta County, Cal., where it seems to be below the zone of secondary sulphide enrichment. He says that "there is no reason to believe that it is secondary." 4

According to Lewis, ${ }^{5}$ chalcocite is the original and essential ore of the Rocky Hill mine, in New Jersey. Likewise the chalcocite in the region of Christiania, Norway, is regarded by V. M. Goldschmidt ${ }^{8}$ as in part a primary mineral.

The copper lodes of the Virgilina district, in Virginia and North Carolina, described by Laney, ${ }^{7}$ are of peculiar interest in this connection. The country is an area of schists and gneisses intruded by granite and diabase. The deposits are fissure veins. The level of ground water is 50 to 75 feet below the surface and the zone of secondary alteration does not appear to extend below 250 feet. The important mines of the district are 350 to 500 feet deep and the ore from the deepest levels contains almost as much chalcocite as bornite. ${ }^{8}$ The ores in the deeper levels show little secondary fracturing, and from this Graton ${ }^{\theta}$ concluded that the chalcocite is in part of primary origin. Laney subsequently worked out the paragenesis of these ores by a microscopic study of polished surfaces. Some of his sections ${ }^{10}$ show a crystallographic intergrowth of bornite and chalcocite in relations that suggest the intergrowth of quartz and feldspar in a graphic granite. It is clear that these two minerals in this ore are contemporaneous, and since the specimens were obtained from considerable depths in tight lodes it can not reasonably be supposed

1 Sales, R. H., Discussion of paper by F.L. Ransome, on "Criteria of downward sulphide enrichment": Econ. Geology, vol. 5, 1910, p. 681.

2 Simpson, J. F., The relation of copper to pyrite in the lean copper ores of Butte, Mont.: Econ. Geology, vol. 3, 1908, p. 634 .

${ }^{3}$ Weed, W. H., Geology and ore deposits of the Butte district, Montana: Prof. Paper U. S. Geol. Survey No. 74,1912 , p. 76. For Weed's final conclusions see this bulletin, p. 176.

${ }^{4}$ Graton, L. C., The occurrence of copper in Shasta County, Cal.: Bull. U. S. Geol. Survey No. 430, 1910, pp. 104-105.

5 Lewis, J. V., Copper deposits of the New Jersey Triassic: Econ. Geology, vol. 2, 1907, p. 247.

${ }^{6}$ Goldschmidt, V. M., Die Kontaktmetamorphose im Kristianiagebiet, 1911, p. 250.

7 Laney, F. B., The relation of bornite and chalcocite in the copper ores of the Virgilina district of North Carolina and Virginia: Econ. Geology, vol. 6, 1911, pp. 399-411.

8 Idem, p. 399.

- Graton, L. C., Copper: Mineral Resources U. S. for 1907, pt. 1, U. S. Geol. Survey, 1908, p. 620.

10 Especially that figured in his P!. VII, fig. 2, p. 406. 
that the minerals were deposited by cold. sulphate waters. Laney ${ }^{1}$ concludes that-

Chalcocite is clearly of two periods-one confined to the upper portions of the vein more recent than and filling a network of minute factures in the bornite; the other contemporaneous and intergrown, often crystallographically, with it. There is no evidence that any of the bornite is of secondary origin. It is therefore believed that in the Virgilina district the greater part of the chalcocite is a primary mineral contemporaneous with the bornite and in no way derived from it or from any other copperbearing minerals by processes of secondary alteration.

It appears possible from these relations that under some conditions chalcocite is deposited as a primary mineral by ascending hot waters. The intergrowth of the copper sulphide in graphic-like pattern is a feature that is difficult to explain on the hypothesis of an origin from descending sulphate waters. Ascending alkaline hot solutions are generally supposed to have deposited the primary ores of nearly all the larger copper deposits. Such solutions are doubtless variable in composition. It appears probable that under conditions where the concentration of iron is low in the solutions chalcocite may form as a primary mineral instead of chalcopyrite, which is the commoner primary ore.

The chalcocite deposits in sandstone and shale which are very widely distributed in the Southwest should be mentioned here. Many of these deposits are in areas remote from igneous rocks and appear not to be related genetically to igneous processes. They have doubtless been deposited by cold waters and some of them have replaced coal or other organic material. In New Mexico, ${ }^{2}$ in Colorado, ${ }^{3}$ and elsewhere, such deposits have formed where there is no evidence that a sulphide existed previously. In the "Red Beds" of Oklahoma, 10 miles northeast of Stillwater, in Payne County, according to W. A. Tarr, ${ }^{4}$ veinlets of chalcocite are found cutting carbonaceous material. The chalcocite and bornite deposits of the Bonanza mine of the Chitina copper belt, Alaska, ${ }^{5}$ probably have a similar genesis. Barite is present in several of these ore bodies, suggesting the agency of sulphate solutions. Although these deposits are not secondary in the sense that they have formed at the expense of older sulphides, the conditions under which they were formed as regards temperature, pressure, and concentration of solu-

1 Laney, F. B., The relation of bornite and chalcocite in the copper ores of the Virgilina district of North Carolina and Virginia: Econ. Geology, vol. 6, 1911, p. 411.

2 Lindgren, Waldemar, Graton, L. C., and Gordon, C. H., The ore deposits of New Mexico: Prof. Paper U. S. Geol. Survey No. 68, 1910, pp. 76-77.

3 Fmmons, S. F., Copper in the red beds of the Colorado Plateau region: Bull. U. S. Geol. Survey No. 260, 1905, pp. 221-232. Emmons, W. H., The Cashin mine, Montrose County, Colo.: Bull. U. S. Geol. Survey No. 285, 1906, pp. 125-128. Lindgren, Waldemar, Notes on copper deposits in Chaffee, Fremont, and Jefferson counties, Colo.: Bull. U. S. Geol. Survey No. 340, 1908, pp. 157-174.

4 Tarr, W. A., Copper in the "Red Beds" of Oklahoma: Econ. Geolog. vol. 5, 1910, p. 223

- Moffit, F. H., and Maddren, A. G., Mineral resources of the Kotsina-Chitins region, Alaska: Bull. U. S. Geol. Survey No. 374, 1909, pp. 80-86. 
tion are probably near those which prevail in processes of sulphide enrichment.

The conditions which are assumed to exist where secondary chalcocite is precipitated have already been stated. The solutions contain copper sulphate, iron sulphate, and probably sulphuric acid. Without much doubt the iron is mainly in the ferrous state. Stokes's equations ${ }^{1}$ indicate that ferrous salt is liberated in the reaction. Winchell ${ }^{2}$ states that hematite does not form where solutions are acid, as at Butte. According to Ransome ${ }^{3}$ the formation of chalcocite at Bisbee was effected without the development of ferric oxide as a by-product. At Globe Ransome did not detect hematite or ferric hydrate in microscopic intergrowths of pyrite-chalcocite ores. Lindgren emphasizes the presence of ferrous sulphate as an attendant of processes of chalcocitization at Morenci, ${ }^{4}$ and this is suggested by analyses of waters from copper deposits of Ely, Nev. One of the deeper waters collected by Lawson carried 9.36 grains per gallon of ferrous sulphate and 0.4 grain per gallon of ferric sulphate. ${ }^{5}$

On the other hand, Kemp shows that iron oxide has formed between covellite and chalcocite in secondary ore of Copper Mountain, British Columbia, ${ }^{\circ}$ which suggests the possibility of hydrolyzation of iron sulphate-a reaction which in acid solution takes place only with the ferric salts.

Experiments in the precipitation of chalcocite have already been reviewed. None of these experiments were carried out under exactly the conditions which probably exist in the secondary sulphide zone. Stokes's experiments (p. 133) were made at a high temperature and ferrous sulphate was not introduced. In Winchell's experiments the chalcocite was formed in the presence of sulphur dioxide, which appears to occur very sparingly, if at all, in waters from most copper mines, though lately Spencer ${ }^{7}$ has indicated the possibility that sulphur dioxide may be formed by the attack of cupric sulphate on pyrite. Ferrous sulphate may accomplish a similar reduction, but in experiments made by Mr. F. F. Grout and myself at the University of Minnesota to test this reaction, no chalcocite has yet formed with pyrite, at the end of one year.

In the synthesis of chalcocite with pyrite, Stokes found that covellite was formed but subsequently changed to cuprous sulphide.

\footnotetext{
1 Stokes, H. N., Experiments on the action of various solutions on pyrite and marcasite: Econ. Geology, vol. 2, 1907, p. 22; See also Lindgren, Waldemar, The copper deposits of the Clifton-Morenci district, Arizona: Prof. P’aper U. S. Geol. Survey No. 43, 1905, p. 183; Wells, R. C., The fractional precipitation of sulphides: Econ. Goology, vol. 5, 1910, p. 1.

2 Winchell, H. V., The synthesis of chalcocite and its genesis at Butte, Mont.: Eng. and Min. Jour., vol. 75, 1903, pp. 783-784.

${ }^{3}$ Ransome, F. L., The geology and ore deposits of the Bisbee quadrangle, Arizona: Prof. Paper U. S. Geol. Survey No. 21, 1904, p. 157.

4 Lindgren, Waldemar, op. cit., p. 186.

S Lawson, A. C., The copper deposits of the Robinson mining district, Nevada: Bull. Dept. Geology Univ. California, vol. 4, 1906, p. 333.

6 Kemp, J. F., Secondary enrichment in ore deposits of copper: Econ. Geology, vol. 1, 1906, p. 16.

'Spencer, A. C., Chalcocite deposition: Jour. Washington Acad. Scl., vol. 3, 1913, p. 73.
} 
(See p. 133.) There are reasons for supposing that this takes place under conditions of sulphide enrichment, the cupric sulphide changing to cuprous sulphide in the presence of cupric sulphate and ferrous sulphate: The cuprous ion has been looked for in vain in at least ten of the analyses of mine waters. On the other hand, Wells has shown that the cuprous ion probably does exist in exceedingly small concentration in solutions of cupric and ferrous sulphate and the direct precipitation of chalcocite is by no means unlikely. More data on this synthesis are needed, especially some on the synthesis in an alkaline environment.

Covellite, CuS, is found in small amounts in many mining districts of North America but is not abundant in many of the larger deposits. As a rule it is associated with chalcocite, and it forms chiefly as a replacement of iron or zinc sulphides. Weed ${ }^{1}$ estimates that covellite has formed 0.5 per cent of the ore mined at Butte. In this region it is secondary and forms in part as an alteration product of chalcocite. It replaces zinc sulphide at Morenci, Ariz., ${ }^{2}$ in the San Francisco district, Utah, ${ }^{3}$ at the Poole mine in the foothill copper belt of California, ${ }^{4}$ and elsewhere. At Lake City, Colo., ${ }^{5}$ according to Irving and Bancroft, small masses of blue sulphide, on being broken into minute cleavage blocks, were found to be sphalerite thinly coated along the numerous cleavage surfaces with covellite films.

In the Last Chance mine of the Cœur d'Alene district, Idaho, lumps of covellite contain minute specks of chalcopyrite, from which the covellite has been formed as an alteration product. ${ }^{\circ}$ It is abundant in the disseminated copper ores at Bingham, Utah, according to B. S. Butler, ${ }^{7}$ and was noted by Boutwell ${ }^{8}$ coating chalcopyrite in the Northern Light mine. It forms from chalcopyrite and pyrite in the Rambler mine, Encampment, Wyo., and in the Eureka pit at Copper Flat, Nev. ${ }^{\circ}$ At Ducktown, Tenn., it covers pyrrhotite. Accordıng to Lindgren covellite is found coating pyrite in sericitized porphyry at Morenci, Ariz. ${ }^{10}$ and it replaces pyrite also in the Nevada Douglas mine, near Yerington, Nev.

\footnotetext{
' Weed, W. E., Geology and ore deposits of the Butte district, Montana: Prof. Paper U. S. Geol. Survey No. 74,1912, pp. $72,76$.

${ }^{2}$ Lindgren, Waldemar, The copper deposits of the Clifton-Morenci district, Arizona: Prof. Paper U. S. Geol. Survey No. 43, 1905, p. 183.

3 Butler, B. S., oral communication.

1 Rogers, A. F., A new synthesis and new occurrences of covellite: School of Mines Quart., Columbia Univ., 1911, p. 300.

${ }^{6}$ lrving, J. D., and Bancroft, Howland, Geology and ore deposits near Lake City, Colo.: Bull. U. S. Geol. Survey No. 478, 1911, p. 64.

${ }^{6}$ Ransome, F. L., and Calkins, F. C., The geology and ore deposits of the Cour d'Alene district, Idaho: Prof. Paper U. S. Geol. Survey No. 62, 1908, p. 92.

7 Oral communication.

${ }^{8}$ Boutwell, J. M., Economic geology of the Bingham mining district, Utah: Prof. Paper U. S. Geol. Survey No. 38, 1905, p. 223.

- Rogers, A. F., A new synthesis and new occurrences of covellite: School of Mines Quart., vol. 32 1911, p. 302.

${ }^{10}$ Lindgren, Waldemar, op. cit., p. 186.
} 
Since the precipitation of cupric sulphide from cupric sulphate solutions involves no change of valence, some very simple equations may be written:

$$
\begin{aligned}
& \mathrm{ZnS}+\mathrm{CuSO}_{4}=\mathrm{CuS}+\mathrm{ZnSO}_{4} . \\
& \mathrm{CuFeS}_{2}+\mathrm{CuSO}_{4}=2 \mathrm{CuS}+\mathrm{FeSO}_{4} \cdot \\
& \mathrm{FeS}+\mathrm{CuSO}_{4}=\mathrm{CuS}+\mathrm{FeSO}_{4} \cdot \\
& \mathrm{H}_{2} \mathrm{~S}+\mathrm{CuSO}_{4}=\mathrm{CuS}+\mathrm{H}_{2} \mathrm{SO}_{4} .
\end{aligned}
$$

With pyrite the reaction is probably more involved.

Like chalcocite, covellite is formed in a reducing environment; doubtless in the presence of ferrous sulphate, but some ferric salt may be present also. A paragenesis noced by Kemp at Copper Mountain, British Columbia, and described by Catherinet, ${ }^{1}$ strongly suggests the presence of ferric ion. The copper minerals, presumably secondary, were formed in the following order: (1) Bornite, (2) covellite and limonite, (3) chalcocite, (4) chalcopyrite and chalcocite. The hydrous iron oxide appears to have formed with covellite between bornite and chalcocite. In view of the fact that limonite forms from ferric rather than from ferrous salt, this association indicates the presence of ferric sulphate. Possibly the iron was deposited from suspension. In this connection the occurrence of considerable finely divided iron oxide suspended in deep waters at Ducktown, Tenn., is suggestive. On the other hand, it is known that changes in acidity bring about reversals in the state of oxidation of some ions in a solution, and the iron oxide may have been precipitated from solution with covellite. The mass of evidence seems to indicate, however, that the precipitation of oxides with copper sulphides is generally subordinate.

Covellite, like chalcocite, is found in ores of the "Red Beds" of the Southwest, where it was deposited as a primary mineral, presumably from cold solutions. Examples of its deposition by ascending thermal waters are exceedingly rare, but at Butte, Mont., it is found at depths as great as 1,600 feet and in associations which, according to Sales, ${ }^{2}$ suggest its deposition by ascending waters. A suite of specimens from the lower levels of the Butte mines, in a collection at the University of Minnesota, shows covellite intergrown with tetrahedrite.

Bornite, $\mathrm{Cu}_{5} \mathrm{FeS}_{4}$, is found in associations that indicate its formation under many different geologic conditions. It has not been clearly identified as a pyrogenic constituent of an igneous rock, but it is a primary mineral of a pegmatite at Copper Mountain, British Columbia ${ }^{3}$ and it is primary in many contact-metamorphic deposits.

1 Catherinet, Jules, Copper Mountain, British Columbia: Eng. and Min. Jour., vol. 79, 1905, p. 125. Kemp, J. F., Secondary enrichment in ore deposits of copper: Econ. Geology, vol. 1, 1906, p. 16.

'Sales, R. H., Discussion of paper by F. I. Ransome, on "Criteria of downward sulphide enrichment": Econ. Geology, vol. 5, 1910, p. 682.

${ }^{8}$ Kemp, J. F., Secondary enrichment in ore deposits of copper: Econ. Geology, vol. 1, 1906, p. 17; The role of the igneous rocks in the formation of veins: Trans. Am. Inst. Min. Eng., vol. 31, 1902, pp. 182-183. 
It occurs in lodes that were formed at great depths and also in some that were formed at moderate depths, and less abundantly in deposits remote from outcrops of igneous rocks. ${ }^{1}$ It is deposited on pyrite and other sulphides by cold copper sulphate waters, and in some deposits it is regarded as an important secondary sulphide. As such it is usually much less abundant than chalcocite. According to Sales ${ }^{2}$ it is both primary and secondary at Butte, Mont., where it results from alterations of pyrite, chalcocite, and enargite and is a transition product between pyrite and chalcocite. According to Weed ${ }^{3}$ it is found mainly above the 1,000-foot level. Sales states that "bornite does not often result from the action of downward-moving surface waters but is generally a product of ascending solutions." Graton ${ }^{4}$ regards it as a primary mineral in the copper deposits of Shasta County, Cal., in some of which it is found as far as 970 feet below the surface. At Bingham, Utah, ${ }^{5}$ bornite is intimately associated with chalcopyrite in the large replacement ore bodies. It is a secondary mineral at Rio Tinto, Spain. ${ }^{\circ}$

Chalcopyrite, $\mathrm{FeCuS}_{2}$, in the greater number of its occurrences is clearly primary, and in many sulphide deposits it is the only important primary copper mineral in the unaltered ore. A list of occurrences of primary chalcopyrite would include nearly all important deposits of copper ore in the United States. It is, however, a "persistent" mineral, and evidence is rapidly multiplying that it is secondary in many deposits. At Bingham, Utah, according to Boutwell, ${ }^{7}$ chalcopyrite is the most important primary copper mineral. It is intimately associated in physical mixtures with pyrite, much of the pyritic ore carrying 3.5 per cent of copper. In the disseminated secondary ores in porphyry a considerable part of the copper is in chalcopyrite. Since it is most abundant in crushed and altered areas, and since it generally occurs along fractures, Boutwell regards it as formed subsequent to the solidification of the porphyry but does not state the nature of the solutions which deposited it. It is a primary constituent of the quartz monzonite at Butte, Mont., and also of the copper ores, but according to Weed ${ }^{8}$ it is not an

1 Lindgren, Waldemar, Graton, L. C., and Gordon, C. H., The ore deposits of New Mexico: Prof. Paper U. S. Geol. Survey No. 68, 1910, pp. 77-78.

2 Sales, R. H., Discussion of paper by F. L. Ransome, on "Criteria of downward sulphide enrichment": Econ. Geology, vol. 5, 1910, p. 682 .

${ }^{3}$ Weed, W. H., Geology and ore deposits of the Butte district, Montana: Prof. Paper U. S. Geol. Survey No. 74,1912, p. 74 .

4 Graton, L. C., The occurrence of copper in Shasta County, Cal.: Bull. U. S. Geol. Survey No. 430, 1910, pp. 104-105.

5 Boutwell, J. M., Economic geology of the Bingham mining district, Utah: Prof. Paper U. S. Geol. Survey No. 38,1905 , p. 106.

6 Finlayson, A. M., The pyritic deposits of Huelva, Spain: Econ. Geology, vol. 5, 1910, p. 419.

7 Boutwell, J. M., op. cit., p. 106.

8 Weed, W. H., op. cit., p. 75. 
important ore mineral at Butte. At Globe it is associated with pyrite in the deeper ores and is abundant in some mines. It occurs with specularite in the Old Dominion, Gibson, and other mines. ${ }^{1}$ No secondary occurrence is mentioned by Ransome. ${ }^{2}$ At Bisbee it is in the main but not altogether primary. Some of it is of more recent origin than pyrite. Specimens taken from the periphery of the ore body on the seventh level of the Spray mine, near the inclosing altered and pyritized limestone, show massive chalcopyrite enveloping kernels of pyrite, and veinlets of chalcopyrite traverse the pyritic nuclei. Ransome says: ${ }^{3}$ "It is necessary to conclude that this particular mass of chalcopyrite was formed after the pyrite and probably in part by alteration or replacement of the latter." According to Kemp, ${ }^{4}$ thin films of later chalcopyrite have been found at Butte, Mont., filling crevices between the tabular crystals of covellite, and it is clearly a secondary mineral at Copper Mountain, near Princeton, British Columbia, ${ }^{5}$ where it is associated with chalcocite and covellite and is probably later than some of the chalcocite of the ore. In Shasta County, Cal., ${ }^{\circ}$ it occurs with zinc blende in veinlets cutting the primary ore, and Graton regards it as in part of secondary origin. At Philipsburg, Mont., it occurs sparingly with zinc blende in veinlets which cut the earlier ore. In the veins of Morenci, Ariz., ${ }^{7}$ chalcopyrite is mainly a primary mineral. In a stope of the Ryerson mine it is associated with chalcocite. Of this occurrence Lindgren says: "Such a connection would suggest its origin as due in this case to secondary sulphide formation by solutions from above, for it is known that chal.copyrite, as well as chalcocite, may form under such conditions." Chalcopyrite is secondary in the rich ore of the Gossan lead, Virginia. ${ }^{8}$ At Ducktown, Tenn., ${ }^{8}$ and in the Rio Tinto mines, Spain, ${ }^{10}$ chalcopyrite enrichment below the chalcocite zone has been a process of considerable economic importance.

Of the chemistry of the precipitation of secondary chalcopyrite very little is known. It has not been formed synthetically by cold sulphate solutions in the laboratory. Since it is a sulphide of both

\footnotetext{
1 Ransome, F. L., oral communication.

${ }^{2}$ Ransome, F. L., Geology of the Globe copper district, Arizona: Prof. Paper U. S. Geol. Survey No. 12, 1903, p. 121.

${ }^{3}$ Ransome, F. L., The geology and ore deposits of the Bisbee quadrangle, Arizona: Prof. Paper U. S. Geol. Survey No. 21, 1904, p. 133.

4 Kemp, J. F., Secondary enrichment in ore deposits of copper: Econ. Geology, vol. 1, 1906, p. 16.

${ }^{5}$ Catherinet, Jules, Copper Mountain, British Columbia: Eng. and Min. Jour., vol. 79, 1905, pp. 125-126.

${ }^{6}$ Graton, L. C., The occurrence of copper in Shasta County, Cal.: Bull. U. S. Geol. Survey No. 430, 1910, p. 104.

${ }^{7}$ Lindgren, Waldemar, The copper deposits of the Clifton-Morenci district, Arizona: Prof. Paper U. S. Geol. Survey No. 43, 1905, p. 106.

8 Weed, W. H., Copper deposits of the Appalachian States: Bull. U. S. Geol. Survey No. 455, 1911, pp. 120-121.

' Emmons, W. H., and Laney, F. B., Preliminary report on the mineral deposits of Ducktown, Tenn.: Bull. U. S. Geol. Survey No. 470, 1911, p. 151.

10 Finlayson, A. M., The pyritic deposits of Huelva, Spain: Econ. Geology, vol. 5, 1910, pp. 410-420.
} 
copper and iron, and since iron sulphide dissolves in acid, it would be supposed that chalcopyrite would not be precipitated in more than feebly acid solutions, although copper sulphide may be precipitated in solutions more highly acid. In view of these relations it would be supposed that the precipitation of chalcopyrite would be chiefly below the chalcocite zone. Such relations are suggested by the occurrences of these minerals in some districts, especially at Ducktown, Tenn.

Enargite, $\mathrm{Cu}_{8} \mathrm{AsS}_{4}$, is a primary mineral of great value at Butte, Mont., is present in considerable amount at Tintic, Utah, and occurs in less abundance at Bingham, Utah, in Gilpin County, Colo., and elsewhere. At Bingham it was found lining druses, showing that it was one of the last minerals deposited, but according to Boutwell ${ }^{1}$ there is no conclusive evidence that it was deposited by sulphate waters. The enargite of Butte, according to Emmons and Tower, is primary. ${ }^{2}$ Weed ${ }^{3}$ observes that some of it was deposited, however, by hot ascending solutions after the earlier chalcopyrite veins had formed. Both Reno Sales ${ }^{4}$ and A. N. Winchell ${ }^{5}$ regard enargite at Butte as mainly primary. It is found in the upper portions of veins above the water level at Butte and at Tintic, but in view of its great insolubility ${ }^{\circ}$ in acid sulphate waters it is probably residual. Little conclusive paragenetic evidence is available that it is deposited by descending sulphate waters. At Butte it is intergrown with chalcocite, but as stated above some of the chalcocite of the Butte deposits is probably primary.

Famatinite, $\mathrm{Cu}_{3} \mathrm{SbS}_{4}$, is not a common ore of copper, and little is known as to its origin. I know of no occurrence that has been described as secondary. In view of the primary origin of enargite, its corresponding arsenic salt, famatinite also is probably of primary origin.

Tetrahedrite, $\mathrm{Cu}_{8} \mathrm{Sb}_{2} \mathrm{~S}_{7}$, is a comparatively common copper mineral. In most of its occurrences it is of primary origin. Its genesis is discussed on page 124.

Tennantite, $\mathrm{Cu}_{8} \mathrm{As}_{2} \mathrm{~S}_{7}$, is the arsenic salt corresponding to tetrahedrite, but it is not so common as tetrahedrite. Its genesis is discussed on page 125 .

\footnotetext{
1 Boutwell, J. M., Economic geology of the Bingham mining district, Utah: Prof. Paper U. S. Geol. Survey No. 38,1905 , p. 108.

2 Weed, W. H., Emmons, S. F., and Tower, G. W., Buttr) special folio (No. 38), Geol. Atlas U. S., U. S. Geol. Survey, 1897, p. 6.

a Weed, W. H., Ore deposition and vein enrichment by ascending hot waters: Trans. Am. Inst. Min. Eng., vol. 33, 1903, p. 748.

4 Sales, R. H., Discussion of paper by F. L, Ransome, on "Criteria of downward sulphide enrichment": Econ. Geology, vol. 5, 1910, p. 681 .

- Winchell, A. N., Idem, p. 488.

'Buehler, H. A., and Gottschalk, V. H., Oxidation of sulphides: Econ. Geology, vol. 5, 1910, p. 31.
} 


\section{SOME CHEMICAL RELATIONS AND MINERALS OF SILVER.}

\section{PRINCIPAL SILVER MINERALS.}

The chemical composition of the principal silver minerals is given below:

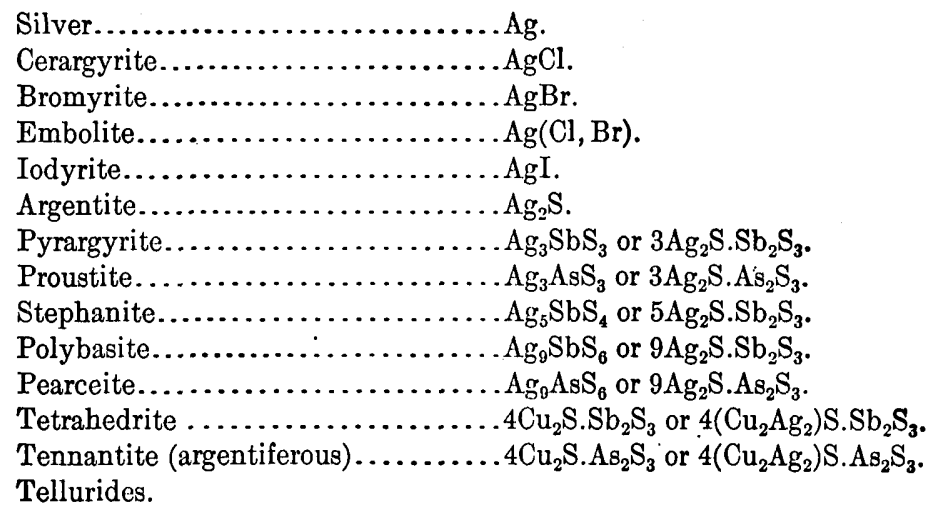

SOLUBILITIES OF SALTS OF SILVER.

The solubilities. of several silver salts in water, determined by Kohlrausch, ${ }^{1}$ are as follows:

\begin{tabular}{|c|c|c|c|c|c|}
\hline $\mathrm{Ag}_{2} \mathrm{SO}_{4}$ & $\mathrm{Ag}_{2} \mathrm{CO}_{3}$ & $\mathrm{AgNO}_{3}$ & $\mathrm{AgCl}$ & $\mathrm{AgBr}$ & $\mathrm{AgI}$ \\
\hline $\begin{array}{c}5.5 \\
.02\end{array}$ & $\begin{array}{c}0.03 \\
.0001\end{array}$ & $\begin{array}{c}2134 \\
8.6\end{array}$ & $\begin{array}{c}0.0016 \\
.00001\end{array}$ & $\begin{array}{c}0.0001 \\
.0000006\end{array}$ & $\begin{array}{c}0.000003 \\
.00000001\end{array}$ \\
\hline
\end{tabular}

The upper number in each column shows the number of grams of the anhydrous salt held in solution in a liter of water, the lower number shows the molar solubility-the number of mols contained in 1 liter of the saturated solution at $18^{\circ} \mathrm{C}$. A more recent determination of the solubility of $\mathrm{Ag}_{2} \mathrm{SO}_{4}$ is 7.7 grams per liter at $17^{\circ} \mathrm{C} .^{2}$

\section{NATURE AND RELATIONS OF THE SILVER MINERALS.}

Silver, like copper, is dissolved in dilute sulphuric acid, and the solubility of its sulphide, like that of the sulphides of copper, is increased by the presence of an oxidizing agent. Like copper, it is precipitated in a reducing environment by metallic sulphides or by hydrogen sulphide. Its sulphide is even less soluble than that of copper. Unlike copper, it does not form stable carbonates, sulphates, or oxides in the oxidizing zone. Its chloride is comparatively insoluble, however, whereas the chlorides of copper dissolve more readily

\footnotetext{
1 Determined by the conductivity method. See Smith, Alexander, Introduction to inorganic chemistrJ, rev. ed., New York, 1910, p. 544.

2 Euler, Hans, Über Löslichkeitserniedrigung: Zeitschr. phys. Chemie, vol. 49, 1904, p. 314.
} 
and rarely accumulate as ores. Although ferrous sulphate and copper sulphate are compatible even in solutions of high concentration, ferrous sulphate precipitates metallic silver from a dilute solution of its sulphate. As silver is 50 to 100 times as valuable as copper, the natural processes which even slightly enrich silver ores are of great commercial interest.

Silver sulphate, which is only slightly soluble, is formed by the action of concentrated sulphuric acid on silver. Ostwald ${ }^{1}$ states that silver sulphate is more soluble in dilute sulphuric acid than in water and that in the reaction an acid salt is probably formed. H. C. Cooke, who recently made a series of experimental studies in the solution and precipitation of silver compounds, informs me that silver sulphide is only slightly soluble in very dilute sulphuric acid, but that if a little ferric sulphate is added to the solution the solubility of the sulphide is considerably increased. He found also that a little ferric sulphate is almost as effective as a considerable amount and believes that the function of ferric sulphate is to oxidize any hydrogen sulphide that is formed, removing it from the system, in which it would suppress further solution of silver sulphide. According to Vogt $^{2}$ ferric sulphate will itself attack metallic silver. Like gold chloride, silver sulphate is easily reduced by many minerals depositing the native metal.

The order of the solubility of the chloride, the bromide, and the iodide of silver are expressed by the order in which they are here named. All of them are very sparingly soluble in water; consequently the halogens will precipitate silver from sulphate solutions and the halides may remain in the upper portions of deposits, giving a considerable enrichment at or near the surface. "In consequence of the progressive insolubility, a cold solution of a bromide will slowly convert the precipitate of silver chloride into bromide, and a soluble iodide will similarly transform the bromide or the chloride into iodide." If the three halogens were equally abundant in mine waters, the bromide and iodide of silver would probably predominate in the silver deposits, but chlorine only is abundant. Consequently cerargyrite, $\mathrm{AgCl}$, is much more common than embolite, $\mathrm{Ag}(\mathrm{Cl}, \mathrm{Br})$; bromyrite, $\mathrm{AgBr}$; iodobromite, $\mathrm{Ag}(\mathrm{Cl}, \mathrm{Br}, \mathrm{I})$; and iodyrite, AgI.

If, in a solution containing the three halogens, chlorides are vastly in excess, silver chloride will be precipitated first, even if bromides and iodides are present, for in mixed solution the least soluble salts are not precipitated first if a more soluble salt is present in sufficiently greater concentration.

1 Ostwald, Wilhelm, The principles of inorganic chemistry (trans. by Alex. Findlay), London, 1904, p. 670 .

2 Vogt, J. H. L., Problems in the geology of ore deposits, in Pošepny, Franz, The genesis of ore deposits, 1902, p. 677.

S Smith, Alexander, Introduction to inorganic chemistry, rev. ed., New York, 1910, p. 629. 
The relations of the halides of silver at Tonopah, Nev., should be mentioned in this connection. According to Burgess ${ }^{1}$ the silver halides at some places occupy fairly well marked horizons in the altered veins. The chloride, cerargyrite, occupies the upper zone, embolite the middle zone, and iodyrite the lower zone. The zones are usually not distinct, and in places two of the minerals are found together. Of these relations Burgess says: ${ }^{2}$

The order of crystallization was chloride, bromochloride, iodide, which is contrary to what would be expected from their respective solubilities, since iodide is the least soluble and would be expected to precipitate first. The reason for this reversal may be involved in the complicated set of conditions under which the reactions occurred and the numerous other minerals present. The most obvious explanation seems to be that the chloride was precipitated first because of the great excess of alkaline chlorides in the solution, and that as the chlorine became reduced in quantity it was partly replaced by bromine, and that the iodide was formed only after the concentration of the other halogens was considerably reduced.

Notwithstanding the low solubilities of the silver halides, it seldom happens that all the silver dissolved in the upper parts of an argentiferous deposit is fixed as halides. The formation of the chloride near the surface does not entirely inhibit the downward migration of silver. The secondary silver sulphides are numerous and in some veins abundant. Among the reasons for the fairly extensive downward migration of silver, even where chlorides are formed, the following may be mentioned:

1. Chlorides are present in the natural waters in some deposits in amounts insufficient to precipitate as chloride all the silver that goes into solution as sulphate.

2. Silver chloride is itself slightly soluble in water.

3. Silver chloride and other halides of silver are soluble in an excess of alkali chlorides.

From this it follows that if a silver solution in the upper part of a deposit contains a certain small amount of alkali chlorides some of the silver will be fixed as chloride; but if it contains sufficient alkali chloride horn silver will be dissolved and will migrate downward with other metals. That some silver is held in solutions containing both sulphates and chlorides is shown by an analysis of mine water reported by Reid. ${ }^{3}$

Silver is readily precipitated as argentite below the zone of oxidation on account of the low solubility of the sulphide- $0.552 \times 10^{-6} \mathrm{mols}$ per liter. ${ }^{4}$ It stands near the end of the Schuermann series, being preceded only by mercury, and accordingly it should replace most

1 Burgess, J. A., The halogen salts of silver and associated minerals at Tonopah, Nev.: Econ. Geology, vol. 6, 1911, p. 13.

Idem, p. 15.

${ }^{8}$ Reid, J. A., The structure and genesis of the Comstock lode: Bull. Dept. Geology Univ. California, vol. 4, 1906, pp. 189-190.

- Weigel, Oskar, Die Iöslichkeit von Schwermetallsulfiden in reinem Wasser: Zeitschr. phys. Chemie, vol. 58,1907, p. 294. 
other metals in sulphide combinations. Ferrous sulphate formed by the reaction of dilute acid and ferric sulphate waters on the several sulphides will precipitate metallic silver from sulphate solutions. With silver sulphate $\left(\mathrm{Ag}_{2} \mathrm{SO}_{4}\right)$ hydrogen sulphide, which, under some conditions at least, is generated by acid reacting upon zinc blende, galena, or other sulphides, gives argentite, which is one of the most important silver minerals in ores. The reaction is-

$$
\mathrm{Ag}_{2} \mathrm{SO}_{4}+\mathrm{H}_{2} \mathrm{~S}=\mathrm{Ag}_{2} \mathrm{~S}+\mathrm{H}_{2} \mathrm{SO}_{4} \text {. }
$$

If the reaction is with galena, or if lead sulphide is precipitated simultaneously with argentite, argentiferous galena may be formed. If arsenic and antimony are present in solution, the complex sulphosalts of these metals may be formed. Of these pyrargyrite is probably the most abundant. Very little is known of the manner of formation of the arsenic and antimony compounds. That both are dissolved in underground water is indicated by the small amounts of arsenic and antimony in gossans and oxidized zones of deposits which contain more of these metals in depth. Although several samples of mine waters show traces of arsenic and antimony, few waters contain appreciable quantities of these elements. The synthesis of the complex compounds they form is difficult under the conditions that are assumed to exist where sulphide enrichment takes place. It is generally supposed that most of them may be either primary or secondary. The data now available indicate that pyrargyrite and proustite are nearly everywhere secondary minerals; that stephanite, polybasite, and pearceite are secondary in most of their occurrences; that tetrahedrite and tennantite, which frequently contain silver as well as copper, are in general primary. The two minerals last named are found at some places in cracks that cut the primary ore, but it is not clear that their occurrence is related to the present topographic surface.

In the subjoined table the more important antimony sulphosalts of silver are put in the first column, the arsenic sulphosalts in the second. Tetrahedrite and tennantite are included, for they are frequently argentiferous.

$$
\begin{aligned}
& \text { Rather common. } \\
& \text { Pyrargyrite }=3 \mathrm{Ag}_{2} \mathrm{~S}_{2} \mathrm{Sb}_{2} \mathrm{~S}_{3} \text {. } \\
& \text { Tetrahedrite }=4 \mathrm{Cu}_{2} \mathrm{~S}_{2} \cdot \mathrm{Sb}_{2} \mathrm{~S}_{3} \text {. } \\
& \text { Stephanite }=5 \mathrm{Ag}_{2} \mathrm{~S}_{2} \mathrm{Sb}_{2} \mathrm{~S}_{3} \text {. } \\
& \text { Polybasite }=9 \mathrm{Ag}_{2} \mathrm{~S} \cdot \mathrm{Sb}_{2} \mathrm{~S}_{3} \text {. } \\
& \text { Rare. } \\
& \text { Proustite }=3 \mathrm{Ag}_{2} \mathrm{~S} \cdot \mathrm{As}_{2} \mathrm{~S}_{3} \text {. } \\
& \text { Tennantite }=4 \mathrm{Cu}_{2} \mathrm{~S} \cdot \mathrm{As}_{2} \mathrm{~S}_{3} \text {. } \\
& \text { Pearceite }=9 \mathrm{Ag}_{2} \mathrm{~S} . \mathrm{As}_{2} \mathrm{~S}_{3} .
\end{aligned}
$$

The minerals in the first column are, as a rule, much more abundant and they are of commoner occurrence than the corresponding minerals in the second column. Proustite is probably less common and less abundant than pyrargyrite, tennantite less common and less abundant than tetrahedrite. Polybasite is not an uncommon mineral, but pearceite has been identified at only a few places. 
If the antimony sulphosalts, where secondary, have been deposited mainly as results of reactions of silver-bearing sulphate waters on stibnite, it would appear that arsenic minerals are less common than the antimony minerals or else that they are less readily replaced under the conditions that exist in veins.

Although there is no invariable rule respecting the relations of the silver chloride, the native metal, the sulphide, and the arsenic and antimony sulphosalts in deposits containing all these minerals, yet in some such deposits some of these minerals have fairly well defined horizons. The chloride is most abundantly developed above the argentite ore; the antimony and arsenic sulphosalts are found with and below the argentite. The native metal is found with the chloride, and, overlapping the zone of chloride ores, it extends downward with argentite. In the Granite-Bimetallic mine, at Philipsburg, Mont., the deeper secondary ores contain very little argentite or native metals, the richer minerals being almost exclusively the dark and the light ruby silver. At Georgetown, Colo., according to Spurr, Garrey, and Ball, argentite predominates in the upper part of the secondary sulphide zones, and the secondary arsenic and antimony sulphosilver minerals are more important below the argentite zone.

\section{OCCURRENCE OF THE SILVER MINERALS.}

Native silver is a primary mineral in some deposits, as in the zeolitic copper ores of Lake Superior, but in sulphide deposits it is generally or invariably secondary. In some districts it is among the most important ore minerals. It commonly occurs as thin flakes or as sheets plastered on the older minerals or as veinlets filling cracks in the ore, and presumably has been formed at many places through the reduction of silver sulphides or other silver-bearing minerals. In the Aspen mining district, Colo., native silver coats crystals of barite and is undoubtedly of relatively late deposition. Wire silver piercing barite is found 900 feet below the surface. ${ }^{1}$ According to Spurr, ${ }^{2}$ silver replaces organic remains in the Aspen district and is found probably 600 feet below the level of ground water. There, he says, in consequence of reduction by carbonaceous matter in the "Weber shales" it has formed instead of the complex salts of silver which generally constitute the richer ores in this province. By processes of reduction native silver forms as an alteration product of many minerals, such as argentite, pyrargyrite, proustite, polybasite; and stephanite. At many places it is pseudomorphous after these. Vogt ${ }^{3}$ says that the native silver of Konigsberg, which is

1 Lindgren, Waldemar, oral communication.

2 Spurr, J. E., Geology of the Aspen mining district, Colorado: Mon. U. S. Geol. Survey, vol. 31, 1898, p. 233; Ore deposition at Aspen, Colo.: Econ. Geology, vol. 4, 1909, p. 315.

3 Vogt, J. H. L., Ueber die Bildung des gediegenen Silbers, besonders des Kongsberger Silbers, durch Secondärprocesse aus Silberglanz und anderen Silbererzen: Zeitschr. prakt. Geologie, vol. 7, 1899, pp. 113-123, 177-181. 
noted for its large and beautiful specimens, is formed by the reduction of argentite. Weed ${ }^{1}$ states that secondary silver ore at Butte is probably first precipitated as argentite, which alters to the native metal. In the Comstock lode native silver is rare but has been noted. At Georgetown, Colo., ${ }^{2}$ polybasite is covered with small specks of native silver, which is probably secondary to the polybasite. A.t Tonopah, Nev., native silver is not abundant but has been observed coating cracks in the primary ore and is entirely secondary. ${ }^{3}$ In the Cœur d'Alene district, Idaho, wire silver is associated with cerusite and limonite in the upper parts of several of the lead-silver veins. $^{4}$ It was an important ore in silver veins and in oxidized portions of copper veins at Butte and in several other districts of Montana. It was found at Creede, Colo., 1,200 feet below the surface. In this district chalcedony and native silver form rich ore. The native silver in deposits of Cobalt, Ontario, is considered secondary.

Ferrous sulphate precipitates silver from sulphate solutions, according to the following reaction: ${ }^{5}$

$$
\mathrm{Ag}_{2} \mathrm{SO}_{4}+2 \mathrm{FeSO}_{4}=2 \mathrm{Ag}+\mathrm{Fe}_{2}\left(\mathrm{SO}_{4}\right)_{3} .
$$

This reaction doubtless accounts for some well-authenticated occurrences of native silver veinlets below the water level, but many other natural precipitants are known. ${ }^{\circ}$

Cerargyrite, horn silver, $\mathrm{AgCl}$, is probably unknown as a primary constituent of ores deposited by ascending hot waters but is frequently developed by weathering, alteration, or enrichment at or near the outcrops of silver-bearing sulphide lodes. A list of its occurrences would include nearly all sulphide deposits in which silver is an important metal. In arid undrained areas it is an important ore mineral, so important that the term "chloriding" is generally used in such regions for pocket hunting near the surface. At many places even where the primary sulphide ores are not profitable the superficial chloride ores may be very rich. The chloride ores generally pass into the sulphides below, and the bottom of the zone of ore carrying horn silver is generally above the bottom of the zone of secondary silver sulphides. Cerargyrite is not everywhere confined to the shallow surface zone, however. In the Comstock lode, where it is not particularly abundant, it was noted, according to Clarence King, at a depth of 900 feet below the surface. Cerargyrite

\footnotetext{
1 Weed, W. H., Geology and ore deposits of the Butte district, Montana: Prof. Paper U. S. Geol. Survey No. 74, 1912, p. 102.

2 Spurr, J. E., and Garrey, G. H., Preliminary report on the ore deposits of the Georgetown mining district, Colorado: Bull. U. S. Geol. Survey No. 260, 1905, p. 119.

8 Spurr, J. E., Geology of the Tonopah mining district, Nevada: Prof. Paper U. S. Geol. Survey No: 42, 1905, p. 95.

4 Ransome, F. L., and Calkins, F. C., The geology and ore deposits of the Cœur d'Alene district, Idaho. Prof. Paper U. S. Geol. Survey No. 62, 1908, p. 90.

- Penrose, R. A. F., jr., The superficial alteration of ore deposits: Jour. Geology, vol. 2, 1894, p. 314.

- For the relations of native silver and copper minerals, see this paper, p. 97.
} 
forms where waters carrying silver sulphates encounter waters bearing chlorides. Silver chloride is only slightly soluble in ordinary ground water and is therefore fairly stable under surface conditions.

Many deposits of cerargyrite ores contain large amounts of manganese oxide. In some of these native silver is present only in small quantity. The presence of manganese oxide delays the generation of ferrous sulphate, which, as already stated, precipitates native silver from ferric sulphate solution. With manganese dioxide in the presence of abundant chlorides horn silver would be precipitated rather than the native metal. Examples of horn-silver ores associated with manganese oxides include the famous deposits of Lake Valley, ${ }^{1}$ near Silver City, N. Mex., the deposits of the Exposed Treasure mine, ${ }^{2}$ near Mohave, Cal., and some silver deposits at Neihart, Mont., ${ }^{3}$ and at Leadville, Colo. ${ }^{4}$ Other deposits, however, containing appreciable though lower proportions of manganese, contain considerable native silver with subordinate chloride; a conspicuous example is the Amethyst vein of Creede, Colo.

Embolite and other halides.-Embolite, $\mathrm{Ag}(\mathrm{Cl}, \mathrm{Br})$; bromyrite, $\mathrm{AgBr}$; iodobromite, $\mathrm{Ag}(\mathrm{Cl}, \mathrm{Br}, \mathrm{I})$; and iodyrite, $\mathrm{AgI}$, are not common minerals, for they contain bromine and iodine, which are rare in mineral solutions. None of them are known to have been formed in hot ascending solutions. They are in the main even less soluble in water than cerargyrite and are therefore comparatively stable when once they are formed. The mutual relations of the silver halides at Tonopah, Nev., have already been reviewed (p. 116).

Argentite, $\mathrm{Ag}_{2} \mathrm{~S}$, is one of the commonest and most important secondary silver minerals, but it occurs also as a primary mineral. It fills postmineral cracks in the secondary zones at Georgetown, Colo., Neihart and Philipsburg, Mont., and many other places. Great bonanzas of argentite were found in upper levels on the Comstock lode. In this lode it has been identified as far as 3,000 feet below the surface but not certainly as a secondary mineral. At Tonopah, Nev., ${ }^{5}$ some occurrences of argentite are primary, but in places it coats crevices that cut the primary ore and is evidently secondary also. Some of the ores show argentite fringing cerargyrite, as if secondary to it. It is probably primary in part at Butte,

\footnotetext{
1 Clark, Ellis, The silver mines of Lake Valley, New Mexico: Trans. Am. Inst. Min. Eng., vol. 24, 1895, p. 148. Lindgren, Waldemar, Graton, L. C., and Gordon, C. H., The ore deposits of New Mexico: Prof. Paper U. S. Geol. Survey No. 68, 1910, pp. 66, 279.

2 De Kalb, Courtenay, Geology of the Exposed Treasure lode, Mojave, Cal.: Trans. Am Inst. Min. Eng., vol. 38,1908, p. 319.

8 Weed, W. H., Geology of the Littlo Belt Mountains, Montana, with notes on the mineral deposits of the Neihart, Barker, Yogo, and other districts, accompanied by a report on the petrography of the igneous rocks of the district by L. V. Pirsson: Twentieth Ann. Rept. U. S. Geol. Survey, pt. 3, 1900, p. 407.

4 Emmons, S. F., Geology and mining industry of Leadville, Colo.: Mon. U. S. Geol. Survey, vol. 12, 1886, p. 562.

- Spurr, J. E., Geology of the Tonopah mining district, Nevada: Prof. Paper U. S. Geol. Survey No. 42, 1905, pp. 92, 94.
} 
Mont., and at Tintic, Utah. Argentite is pseudomorphous after ruby silver (and vice versa) at Joachimsthal, Bohemia.

Silver sulphide is the least soluble sulphide of the commoner metals, except mercury and bismuth, and in reactions involving double decomposition it would be precipitated from argentiferous solutions before all except these sulphides. A search for pseudomorphs after copper sulphide, sphalerite, and pyrite has shown surprisingly few clearly defined examples, although it probably does replace these sulphides metasomatically. If sulphuric acid should in its descent encounter a soluble sulphide like zinc blende, hydrogen sulphide and zinc sulphate might be formed. The hydrogen sulphide would precipitate silver sulphide from a solution containing $\mathrm{Ag}_{2} \mathrm{SO}_{4}$. Argentite could be precipitated in any of the following reactions:

$$
\begin{aligned}
& \mathrm{H}_{2} \mathrm{~S}+\mathrm{Ag}_{2} \mathrm{SO}_{4}=\mathrm{H}_{2} \mathrm{SO}_{4}+\mathrm{Ag}_{2} \mathrm{~S} . \\
& \mathrm{ZnS}+\mathrm{Ag}_{2} \mathrm{SO}_{4}=\mathrm{ZnSO}_{4}+\mathrm{Ag}_{2} \mathrm{~S} . \\
& \mathrm{PbS}+\mathrm{Ag}_{2} \mathrm{SO}_{4}=\mathrm{PbSO}_{4}+\mathrm{Ag}_{2} \mathrm{~S} .
\end{aligned}
$$

The precipitation of argentite from silver sulphate solution does not necessitate a change in valence like that which takes place when chalcocite is formed.

Pyrargyrite, dark ruby silver, $3 \mathrm{Ag}_{2} \mathrm{~S} . \mathrm{Sb}_{2} \mathrm{~S}_{3}$, is probably the most important secondary silver mineral in a large number of silver mines in the United States. So far as known, it is confined to epigenetic deposits, and it is particularly conspicuous in many deposits of early and middle Tertiary age in the American Cordillera. It is not known as a primary mineral of contact-metamorphic and nearly related deposits. In the Granite-Bimetallic mine, at Philipsburg, Mont., pyrargyrite is perhaps the most important mineral. It occurs as small specks intimately intergrown with quartz and stibnite and may possibly be primary, but it is very much more abundant as a secondary mineral in this mine. Most of it lines vugs or occurs in small veinlets that cut across the banding of the primary ore, in which stibnite is abundant. At Tonopah, Nev., pyrargyrite coats crevices that cut the primary ore and is evidently secondary. ${ }^{1}$

Little is known of the synthesis of pyrargyrite under conditions of sulphide enrichment. The assumption that it forms under such conditions rests on paragenetic evidence and the fact that it frequently disappears with increase in depth. Pyrargyrite is an important ore mineral at Georgetown, Lake City, Ouray, and Telluride, Colo.; at the Comstock lode, Austin, Tuscarora, and other districts of Nevada; and at Neihart, Butte, and other places in Montana. At all these places it is probably, in part, at least, of secondary origin.

1 Spurr, J. E., Geology of the Tonopah mining district, Nevada: Prof. Paper U. s. Geol. Survey No. 42, 1905, p. 94 . 
Pyrargyrite is an important constituent of the ore of the famous silver mines of Zacatecas, Guanajuato, and Pachuca, Mexico. Mineralogically the ores of these deposits are nearly related to those of the Comstock lode and Tonopah, Nev.

On the horizon of pyrargyrite at Lake City, Colo., the following, from Irving and Bancroft, ${ }^{1}$ is a par.icularly clear statement:

Ruby silver occurred, so far as could be learned, in all of the mines at the plane of demarcation between sulphides and oxides and, in generally decreasing quantity, to several hundred feet below this level. Along cracks and fissures it occurred in isolated masses to great depths-for instance, at 1,200 feet in the Golden Fleece and at 1,300 feet in the Ilma. These deep occurrences are, however, uncommon and merely indicate the presence of some easy line of access for downward-moving solutions.

Ruby silver has probably resulted from the solutions of silver and antimony obtained by the decomposition of the tetrahedrite and possibly to some extent also from the argentiferous galena. The chemistry of both the solution and reprecipitation of the antimonial and arsenical sulphur compounds has not yet been worked out in sufficient detail to permit a statement of the probable steps of the process, but the geological facts show that it has occurred. The proofs of the secondary character of the ruby silver are:

1. Its restriction in quantity to the upper levels of the mines.

2. Its invariable occurrence as the latest deposited mineral in the veins, either in cracks or crevices in shattered primary ore or as crystals in cavities.

3. Its occurrence only in isolated bunches in deeper workings, where its origin is probably due to the presence of water channels that permit the downward percolation of water from above.

4. Its complete absence from the great mass of deep-seated ore.

It is clearly secondary in all of a large number of specimens of silver ores from the Southwest.

In some mines ruby silver is found at very considerable depths, however, possibly below the zone of secondary alteration. At Przibram, for example, it is said to be found 3,500 feet below the surface.

Proustite, light ruby silver, $3 \mathrm{Ag}_{2} \mathrm{~S}_{2} \mathrm{As}_{2} \mathrm{~S}_{3}$, is similar to pyrargyrite in its occurrence and is commonly regarded as a secondary mineral. Whether it is ever primary is a moot question. Proustite is a secondary mineral at Lake City, Ouray, Silverton, Telluride, and Rico, Colo., ${ }^{2}$ at Philipsburg, Mont., at Austin, Nev., in the Cœur d'Alene district, Idaho, ${ }^{3}$ and in several other districts. It has been noted on the Comstock lode but is not abundant there.

Discussing the genesis of argentite, proustite, pyrargyrite, stephanite, and polybasite, Ransome ${ }^{4}$ says:

It is quite possible that further study of ore deposits may result in showing that some of these minerals, especially proustite, are fully as characteristic of downward enrichment as is chalcocite.

${ }^{1}$ Irving, J. D., and Bancroft, Howland, Geology and ore deposits near Lake City, Colo.: Bull. U. 8. Geol. Survey No. 478,1911, p. 63.

2 Idem, p. 35.

${ }^{3}$ Ransome, F. L., and Calkins, F. C., The geology and ore deposits of the Cour d'Alene district, Idaho: Prof. Paper U. S. Geol. Survey No. 62, p. 93.

- Ransome, F. L., Criteris of downward sulphide enrichment: Econ. Geology, vol. 5, 1910, p. 211. 
Sommerlad ${ }^{1}$ prepared proustite by heating silver chloride and arsenic trisulphide, and many other syntheses are known. ${ }^{2}$ I have no record of the formation of proustite in cold sulphate waters.

Stephanite, brittle silver, $5 \mathrm{Ag}_{2} \mathrm{~S}_{2} \mathrm{Sb}_{2} \mathrm{~S}_{3}$, is an important mineral on the Comstock lode, at Tuscarora and Tonopah, Nev., at Georgetown, Aspen, and Rico, Colo., and in many other silver districts. It generally accompanies ruby silver and polybasite, and in some districts it occurs, like them, in cracks cutting the primary ore. On the Comstock lode, according to King, ${ }^{3}$ broken fragments of quartz themselves containing ore have been recemented by sheets of stephanite. In general its occurrences in the United States are not clearly described, and its genesis is more or less uncertain.

Polybasite, $9 \mathrm{Ag}_{2} \mathrm{~S} \mathrm{Sb}_{2} \mathrm{~S}_{3}$, is commonly a secondary mineral. It occurs at Georgetown, Colo., in cracks cutting the primary ore, ${ }^{4}$ and in the main is related to the present surface. At Neihart, Mont., ${ }^{5}$ it occurs in postmineral fractures and in. vugs and incrusts primary sulphides. It occurs with barite in the Mollie Gibson mine at Aspen, Colo., where it alters to native silver. It is probably secondary in the Comstock lode, Nevada, and in several districts in San Juan, Colo. At Tonopah, Nev., ${ }^{7}$ polybasite is found as deep as 500 feet below the surface in fractures that cut older sulphides, but according to Spurr it is not certain that it was deposited by descending solutions. In many other districts it is regarded as a secondary mineral, for it is not abundant in the deeper levels.

Although polybasite has been formed synthetically no record of its synthesis from cold sulphate waters is available. H. C. Cooke ${ }^{8}$ treated powdered stibnite with cold dilute silver sulphate solution and obtained a rich antimony-silver ore but did not identify the material as polybasite.

Pearceite, $9 \mathrm{Ag}_{2} \mathrm{~S}_{1} \cdot \mathrm{As}_{2} \mathrm{~S}_{3}$, is less common than the corresponding antimony salt, polybasite. It is generally assumed to be secondary. According to Weed, it constitutes much of the rich silver ore of

\footnotetext{
1 Sommerlad, Hermann, Über einige Versuche zur Herstellung von Sulfantimoniten und Sulfarseniten des Silbers auf trockenem Wege: Zeitschr. anorg. Chemie, vol. 15, 1897, p. 177; Über Versuche zur Darstellung von Sulfantimoniten und Sulfarseniten des Silbers, Kupfers und Bleis auf trockenem Wege: Idem, vol. 18, 1898, pp. 420-447.

2 Clarke, F. W., The data of geochemistry; 2d ed.: Bull. U. S. Geol. Survey No. 491, 1911, p. $62 \dot{4}$.

$8 \mathrm{King}$, Clarence, The Comstock lode: U. S. Geol. Expl. 40th Par., vol. 3, 1870, p. 81.

4 Spurr, J. E., and Garrey, G. H., Economic geology of the Georgetown quadrangle (together with the Empire district), Colo., with general geology by S. H. Ball: Prof. Paper U. S. Geol. Survey No. 63, 1908, p. 261.

6 Weed, W. H., Geology of the Little Belt Mountains, Mont., with notes on the mineral deposits of the Neihart, Barker, Yogo, and other districts, accompanied by a report on the petrography of the igneous rocks of the district by L. V. Pirsson: Twentieth Ann. Rept. U. S. Geol. Survey, pt. 3, 1900, p. 407.

- Spurr, J. E., Geology of the Aspen mining district, Colorado, with atlas: Mon. U. S. Geol. Survey, vol. 31, 1898, pp. 224-225.

${ }^{7}$ Spurr, J. E., Geology of the Tonopah mining district, Nevada: Prof. Paper U. S. Geol. Survey No. 42, 1905, p. 95.

8 Unpublished data.

๑ Weed, W. H., The enrichment of gold and silver veins, in Pošepny, Franz, The genesis of ore deposits, 1902, p. 494.
} 
Neihart, Mont. Pearceite, intimately associated with galena, has been identified ${ }^{1}$ from the Mollie Gibson mine, Aspen, Colo. In the Drumlummon mine, Marysville, Mont., according to Penfield, ${ }^{2}$ it lines a vug and is intimately associated with chalcopyrite, calcite, and quartz.

Tetrahedrite, gray copper, ${ }_{4} \mathrm{Cu}_{2} \mathrm{~S} \mathrm{Sb}_{2} \mathrm{~S}_{3}$, is rather widely distributed but is of subordinate importance as a source of copper. The argentiferous variety, freibergite, is an important source of silver in many deposits. In the San Juan region, Colo., tetrahedrite is abundant in many deposits and is regarded as a primary constituent in this region. $^{3}$ It is primary at Butte, but its corresponding arsenic compound, tennantite, is said to be secondary." In the Leonard mine some tetrahedrite is later than enargite. ${ }^{5}$ At Ouray and Lake City, Colo., according to Irving and Bancroft, ${ }^{8}$ it was deposited by ascending hot waters, but mainly in the upper parts of the lodes, which at Lake City have a vertical range of over 5,000 feet. The corresponding arsenic compound, tennantite, has not been recognized. Tetrahedrite appears to be primary in Clear Creek County, Colo. ${ }^{7}$ At Cripple Creek, Colo., it is primary and persists to depths of 2,000 feet below the surface. ${ }^{8}$ It is found also at Nevada City ${ }^{9}$ and, intergrown with electrum, at Ophir, ${ }^{10}$ Cal. At Elkhorn, Mont., ${ }^{11}$ it is probably the parent sulphide of rich altered silver ores.

At Bingham, Utah, according to Boutwell, ${ }^{12}$ tetrahedrite is secondary. Crystals of pyrite are coated by chalcopyrite and the latter by tetrahedrite. In the Centennial mine, ${ }^{13}$ in the Empire district, Colorado, tetrahedrite forms in cracks of chalcopyrite in auriferous lodes and is said to be derived from it. Tetrahedrite is said to be second-

1 Penfeld, S. L., On pearceite, a sulpharsenite of silver, and on the crystallization of polybasite: Proc. Colorado Sci. Soc., vol. 5, 1896, p. 211.

Idem, pp. 217-218.

8 Ransome, F. L., A report on the economic geology of the Silverton quadrangle, Colorado: Bull. U.S. Geol. Survey No. 182, 1901, p. 78; Criteria of downward sulphide enrichment: Econ. Geology, vol. 5, 1910, p. 212.

- Weed, W.H., Emmons, S. F., and Tower, G. W., Butte special folio (No. 38), Geol. Atlas U. S., U. S. Geol. Survey, 1897, p. 6.

- Weed, W. H., Geology and ore deposits of the Butte district, Montana: Prof. Paper U. S. Geol. Survey No. 74,1912, p. 78.

- Irving, J. D., and Bancroft, Howland, Geology and ore deposits near Lake City, Colo.: Bull. U. S. Geol. Survey No. 478, 1911, pp. 34, 52.

7 Kemp, J. F., Secondary enrichment in ore deposits of copper: Econ. Geology, vol. 1, 1906, p. 22.

8 Lindgren, Waldemar, and Ransome, F. L., Geology and gold deposits of the Cripple Creek district, Colorado: Prof. Paper U. S. Geol. Survey No. 54, 1906, pp. 121-122.

- Lindgren, Waldemar, The gold-quartz veins of Nevada City and Grass Valley districts, California: Seventeenth Ann. Rept. U. S. Geol. Survey, pt. 2, 1896, p. 119.

10 Lindgren, Waldemar, The gold-silver veins of Ophir, Cal.: Fourteenth Ann. Rept. U. S. Geol. Survey, pt. 2, 1894, p. 273.

11 Weed, W. H., Geology and ore deposits of the Elkhorn mining district, Jefferson County, Mont.: Twenty-second Ann. Rept. U. S. Geol. Survey, pt. 2, 1901, p. 450.

18 Boutwell, J. M., Economic geology of the Bingham mining district, Utah: Prof. Paper U. S. Geol. Survey No. 38, 1905, pp. 107, 220, 222-223.

${ }^{13}$ Spurr, J. E., and Garrey, G. H., Economic geology of the Georgetown quadrangle (together with the Empire district), Colorado, with general geology by S. H. Ball: Prof. Paper U. S. Geol. Survey No. 63, 1908, p. 148. 
Rio Tinto, Spain. ${ }^{1}$ The interesting occurrences of primary tetrahedrite veinlets which cut older sulphides in the Mina Mexico vein, Sonora, ${ }^{2}$ are mentioned on page 46.

Tetrahedrite has not been formed synthetically under conditions that prevail in the secondary sulphide zone. The formula of the argentiferous variety, freibergite, has been written as a combination of chalcocite, argentite, and stibnite- $4\left(\mathrm{Cu}_{2} \mathrm{~S} . \mathrm{Ag}_{2} \mathrm{~S}\right) \mathrm{Sb}_{3} \mathrm{~S}_{3}$ - but since these minerals have dark streaks and freibergite has a reddish-brown streak, this interpretation of the formula is open to question. Possibly the ruby-silver molecule is present.

Tennantite, $4 \mathrm{Cu}_{2} \mathrm{~S} . \mathrm{As}_{2} \mathrm{~S}_{3}$, is regarded as having the same range of occurrence as the corresponding antimony sulphide, tetrahedrite. It is not so common, however, and comparatively few detailed descriptions of its occurrence as a secondary mineral are available. It is said to be secondary at Butte, Mont., ${ }^{3}$ where, according to Emmons and Tower, it seems to result from the decomposition of enargite, with which it is always associated.

Other silver minerals.-Several other silver minerals, all comparatively rare species, have been regarded as secondary. Among these are stromeyerite, ${ }^{4} \mathrm{AgCuS}$; dyscrasite, ${ }^{5} \mathrm{Ag}_{8} \mathrm{Sb}(?)$; and possibly stetefeldtite. $^{b}$ Of these, stromeyerite corresponds in composition to argentiferous chalcocite. In the Yankee Girl mine, near Silverton, ${ }^{-C o l o . ~}$ it is associated with chalcocite and bornite. Since secondary sulphides of silver and copper are precipitated together, it would be supposed that stromeyerite would develop in many deposits. The silver compound in argentiferous chalcocite has not yet been identified, however.

\section{SOME CHEMICAL RELATIONS AND MINERALS OF GOLD.}

\section{SOLUBILITY OF GOLD.}

Although gold belongs to the same chemical family as copper and silver it differs in many respects from both these metals. It forms no insoluble compound in the oxidized zone and its sulphide is not precipitated by mineral waters. Unlike copper and silver it is insoluble in sulphuric acid. Wurtz ${ }^{7}$ stated, in 1858, that ferric sulphate dissolves gold, and his statement has frequently been quoted

1 Finlayson, A. M., The pyritic deposits of Huelva, Spain: Econ. Geology, vol. 5, 1910, p. 411.

2 Hynes, D. P., Notes on the geology of the Mina Mexico vein: Econ. Geology, vol. 7, 1912, pp. 285-286.

3 Weed, W. H., Emmons, S. F., and Tower, G. W., Butte special folio (No. 38), Geol. Atlas U. S., U. S. Geol. Survey, 1897, p. 6.

- Emmons, S. F., The secondary enrichment of ore deposits: Trans. Am. Inst. Min. Eng., vol. 30, 1901, p. 196.

o Smith, George, The ore deposits of the Australian Broken Hill Consols mine, Broken Hill, New South Wales: Trans. Am. Inst. Min. Eng., vol. 26, 1897, pp. 69-78.

- Spurr, J. E., Ore deposits of the Silver Peak quadrangle, Nevada: Prof. Paper U. S. Geol. Survey No.55, 1906, p. 120.

' Wurtz, Henry, Contributions to analy tical chemistry: Am. Jour. Sci., 2d ser., vol. 26, 1858, p. 51. 
in discussions of the processes of enrichment of gold deposits. It is, indeed, a common statement that ferric sulphate is the principal agent in the enrichment of gold deposits. Stokes ${ }^{1}$ showed, however, that ferric sulphate will not dissolve gold, even at $200^{\circ} \mathrm{C}$., except in the presence of a chloride, and its insolubility in ferric chloride and in ferric sulphate at ordinary temperatures has been verified by A. D. Brokaw. ${ }^{2}$ W. J. McCaughey ${ }^{3}$ found that gold is dissolved in a concentrated solution of hydrochloric acid and ferric sulphate and also in a concentrated solution of hydrochloric acid and cupric chloride, both experiments being carried on at temperatures from $38^{\circ}$ to $43^{\circ} \mathrm{C}$. Pearce, ${ }^{4}$ Don, ${ }^{5}$ and Rickard ${ }^{8}$ performed experiments in which gold was dissolved in the presence of a chloride and manganese dioxide. Hydrochloric acid forms in the presence of sodium chloride and sulphuric acid, and in the presence of an oxidizing agent the hydrogen ion is removed to form water, leaving the chlorine in the so-called "nascent state." In this state it is in the uncombined or atomic condition and its attack is more vigorous. It is known that several oxides will release "nascent chlorine" at low temperatures if the solutions are sufficiently concentrated, but in moderately dilute solutions manganese oxides are probably the only common ones that are appreciably effective. Ferric chloride, ferric sulphate, and cupric salts are not more than a fraction of 1 per cent as effective as manganese salts and doubtless this fraction is exceedingly small. ${ }^{\text {? }}$

A number of experiments on the solubility of gold in cold dilute solutions were made at the request of the writer by Mr. A. D. Brokaw. ${ }^{8}$ The nature of these experiments is shown by the following statements, in which $a$ and $b$ represent duplicate tests:

(1) $\mathrm{Fe}_{2}\left(\mathrm{SO}_{4}\right)_{3}+\mathrm{H}_{2} \mathrm{SO}_{4}+\mathrm{Au}$.

(a) No weighable loss. (34 days.)

(b) No weighable loss.

(2) $\mathrm{Fe}_{2}\left(\mathrm{SO}_{4}\right)_{3}+\mathrm{H}_{2} \mathrm{SO}_{4}+\mathrm{MnO}_{2}+\mathrm{Au}$.

(a) No weighable loss. (34 days.)

(b) 0.00017 gram loss. ${ }^{\circ}$

1 Stokes, H. N., Experiments on the solution, transportation, and deposition of copper, silver, and gold: Econ. Geology, vol. 1, 1906, p. 650.

2 Brokaw, A. D., The solution of gold in the surface alterations of ore bodies: Jour. Geology, vol. 18, 1910, p. 322.

${ }^{3}$ McCaughey, W. J., The solvent offect of ferric and cupric salt solutions upon gold: Jour. Am. Chem. Soc., vol. 31, 1909, p. 1263.

4 Pearce, Richard, Discussion of paper by T. A. Rickard, on "The origin of the gold-bearing quartz of the Bendigo Reefs, Australia": 'Trans. Am. Inst. Min. Eng., vol. 22, 1894, p. 739.

6 Don, J. R., The genesis of certain auriferous lodes: Trans. Am. Inst. Min. Eng., vol. 27, 1898, p. 599.

- Rickard, T. A., The Enterprise mine, Rico, Colo.: Trans. Am. Inst. Min. Eng., vol. 26, 1897, pp. 978-979.

7 Emmons, W. H., The agency of manganese in the superficial alteration and secondary enrichment of gold deposits in the United States: Bull. Am. Inst. Min. Eng., 1910, pp. 789-791.

8 Brokaw, A. D., op. cit., pp. 321-326.

- This duplicate was found to contain a trace of $\mathrm{Cl}$, which probably accounts for the loss. 
(3) $\mathrm{FeCl}_{3}+\mathrm{HCl}+\mathrm{Au}$.

(a) No oweighable loss. (34 days.)

(b) No weighable loss.

(4) $\mathrm{FeCl}_{3}+\mathrm{HCl}+\mathrm{MnO}_{2}+\mathrm{Au}$.

(a) 0.01640 gram loss. Area of plate, 383 square millimeters. (34 days.)

(b) 0.01502 gram loss. Area of plate, 348 square millimeters.

In each experiment the volume of the solution was 50 cubic centimeters. The solution was one-tenth normal with respect to ferric salt and to acid. In the second and fourth experiments 1 gram of powdered manganese dioxide was also added. The gold, assaying 0.999 fine, was rolled to a thickness of about 0.002 inch, cut into pieces of about 350 square millimeters area, and one piece, weighing about 0.15 gram, was used in each duplicate.

To approximate natural waters more closely, a solution was made one-tenth normal as to ferric sulphate and sulphuric acid and onetwenty-fifth normal as to sodium chloride. Then 1 gram of powdered manganese dioxide was added to 50 cubic centimeters of the solution, and the experiment was repeated. The time was 14 days.

(5) $\mathrm{Fe}_{2}\left(\mathrm{SO}_{4}\right)_{3}+\mathrm{H}_{2} \mathrm{SO}_{4}+\mathrm{NaCl}+\mathrm{Au}$.

No weighable loss.

(6) $\mathrm{Fe}_{2}\left(\mathrm{SO}_{4}\right)_{3}+\mathrm{H}_{2} \mathrm{SO}_{4}+\mathrm{NaCl}+\mathrm{MnO}_{2}+\mathrm{Au}$.

Loss of gold, 0.00505 gram.

The loss is comparable to that found in experiment 4, allowing for the shorter time and the greater dilution of the chloride.

Although the concentration of chlorine in most of these experiments is greater than that which is found in many mineral waters, it is noteworthy that solution of gold will take place with even a trace of chlorine (see experiment $2 b$ ), and without much doubt these reactions will go on also in the presence of only minute quantities of manganese oxides.

The solution of gold is probably most important, however, in the upper parts of the oxidized zones where most of the pyrite has been removed, for on oxidation pyrite yields ferrous sulphate, which tends to inhibit solution. The small amount of sulphuric acid which seems to be necessary for the reactions could easily be supplied, even above the zone where pyrite persists, by the leaching of basic iron sulphates, the formation of which tends to delay the downward migration of a portion of the sulphuric acid that is released where ferric sulphate alters to limonite. 


\section{PRECIPITATION OF GOLD WITH MANGANESE OXIDE.}

Where it is held in solution as chloride, gold is readily precipitated by ferrous sulphate, which, as already stated, is formed by the action of acid on pyrite or other iron sulphides. If much manganese oxide is present, however, the ferrous sulphate is immediately oxidized to ferric sulphate, which does not precipitate gold from solutions in which it is held as chloride. In the presence of manganese oxides, therefore, gold is not only dissolved in acid solution, but the conditions under which it is precipitated may be delayed. Gold may be carried in acid solution so long as the higher oxides of manganese are present.

In many gold deposits manganese oxides and gold are intimately associated and without doubt have been precipitated together. This association is by no means uncommon. The deposits of the Camp Bird mine, ${ }^{1}$ of the Tomboy mine, ${ }^{2}$ of the Amethyst vein at Creede, Colo. ${ }^{3}$ of the Dahlonega mines, in Georgia, ${ }^{4}$ and of mines at Philipsburg, Mont., ${ }^{5}$ are noteworthy examples. ${ }^{6}$

These relations indicate a process by which gold is precipitated along with manganese oxide in a reducing environment. On this point Mr. R. C. Wells offers the following statement:

The precipitation of manganese will occur more and more as the solution loses its acidity. It is well established that manganous salts in an acid environment are very stable; but in neutral or alkaline solutions they oxidize more vigorously, one stage of their oxidation being the manganic salt, which hydrolyzes into $\mathrm{MD}_{2} \mathrm{O}_{3} \cdot \mathrm{H}_{2} \mathrm{O}$ (manganite) with even greater ease than ferric salts into limonite.

In these ways the inigration of an acidic solution would result in the transportation of both gold and manganese. But in a region of basic, alkaline, and reducing environment the manganese would be reprecipitated, the free acid neutralized, the chlorine absorbed by the bases and removed, and owing to the accumulation of the ferrous or other reducing salts the gold would be reprecipitated.

Some experiments in the precipitation of gold have recently been made by Mr. A. D. Brokaw, who offers me the following data in advance of publication. Into an acid solution in which gold was dissolved in the presence of manganese a crystal of calcite was introduced. On decreasing acidity of the solution with calcium carbonate gold was precipitated with manganese oxide on the surface and in the cleavage cracks of the calcite crystals. The reactions may be stated as follows:

$$
\begin{aligned}
& 2 \mathrm{AuCl}_{3}+3 \mathrm{MnCl}_{2}+6 \mathrm{H}_{2} \mathrm{O} \rightleftarrows 2 \mathrm{Au}+3 \mathrm{MnO}_{2}+12 \mathrm{HCl}, \\
& \text { or } 2 \mathrm{AuCl}_{3}+3 \mathrm{MnSO}_{4}+6 \mathrm{H}_{2} \mathrm{O} \rightleftarrows 2 \mathrm{Au}+3 \mathrm{MnO}_{2}+3 \mathrm{H}_{2} \mathrm{SO}_{4}+6 \mathrm{HCl}, \\
& \text { or } 2 \mathrm{Au}^{+++}+3 \mathrm{Mn}^{++} \rightarrow 2 \mathrm{Au}+3 \mathrm{Mn}^{++++} \text {. }
\end{aligned}
$$

\footnotetext{
- ${ }^{1}$ Ransome, F. L., A report on the economic geology of the Silverton quadrangle, Colorado: Bull. U. S. Geol. Survey No. 182, 1901, p. 202.

2 Purington, C. W., Preliminary report on the mining industries of the Telluride quadrangle, Colorado: Eighteenth Ann. Rept. U. S. Geol. Survey, pt. 3, 1908, pp. 838-841.

3 Emmons, W. H., and Larsen, E. S., A preliminary report on the geology and ore deposits of Creede, Colo.: Bull. U. S. Geol. Survey No. 530, 1913, p. 58.

${ }^{4}$ Laney, F. B., oral communication.

'Emmons, W. H., and Calkins, F. C., Geology and ore deposits of Philipsburg, Mont.: Prof. Paper U. S. Geol. Survey No. 78 (in press).

'See also Tolman, C. F., jr., Secondary sulphide enrichment of ores: Min. and Scl. Press, vol. 106, 1913, p. 41.
} 
These reactions indicate processes by which gold held in acid solution in the presence of manganese salts may be precipitated in the deeper zones, together with manganese oxides, when the solutions reacting on alkaline minerals lose acidity. In general, however, the manganiferous gold ores that are formed in the lower zones of gold deposits carry more manganese than gold and a larger proportion of manganese than would be precipitated by the reaction above indicated. Possibly some of the manganese is precipitated on neutralization as hydroxide, which oxidizes almost immediately on being exposed to air, or perhaps as some other manganese compound that is soluble in acid but insoluble in alkaline solutions.

In some deposits there is evidence that gold has been dissolved and reprecipitated in the surficial zone, yet the secondary gold ore carries no manganese, or at least not more than a trace of manganese compounds. Such relations, according to Ransome, ${ }^{1}$ are indicated by the gold veins of Farncomb Hill, in the Breckenridge district, Colorado, where the secondary gold ore is almost free from manganese. It has been stated that gold may be precipitated from solutions in which it is dissolved as chloride either by the neutralization of the solution or by ferrous sulphate generated by the action of the solution on pyrite. Ferrous sulphate will precipitate gold even from strongly acid solutions in which manganese would still remain in solution. It follows that manganese might not be precipitated with gold from acid solutions even where manganese dioxide has supplied conditions for its solution in chloride waters; but from neutralized solutions the gold and manganese would go down perhaps simultaneously. Gold is precipitated from chloride solution also by native metals, sulphides, organic matter, and many other materials.

The size of the particles of gold has little value as a means of determining its origin. The gold deposited by the reduction or the neutralization of manganiferous compounds may be finely pulverulent or it may form nuggets of considerablesize. Mr. Brokaw, in the experiments cited above, where gold and manganese were precipitated on calcite, obtained masses of gold distinctly visible without a hand lens.

In some deposits the purity or fineness of the gold may afford a means by which primary may be distinguished from secondary gold. In a deposit in northern Nevada the rich gold ore is electrum, a lightcolored natural alloy of gold and silver. On this, deposited presumably from cold solutions, are small masses of dark-yellow gold which is apparently of great fineness. This criterion should be applied with caution, however, and the relations should be established independently for each particular deposit, for under some conditions doubtless secondary gold and silver are precipitated together.

1 Ransome. F. L., Geology and ore deposits of the Breckenridge district, Colorado: Prof. Paper U. S. Geol. Survej' No. 75, 1911, p. 170.

$72293^{\circ}-$ Bull. $529-13-9$ 


\section{SOURCES OF MANGANESE IN GOLD DEPOSITS.}

It has been shown that the solution of gold depends on the presence of chlorine in the mineral waters, and the distribution of chlorine has been discussed briefly on page 66. But chlorine is an efficient solvent of gold only when in the "nascent" state, and under natural conditions nascent chlorine is released principally by manganese oxides. The sources and distribution of manganese are therefore of some importance in connection with the concentration of gold. The important manganese minerals are listed below.

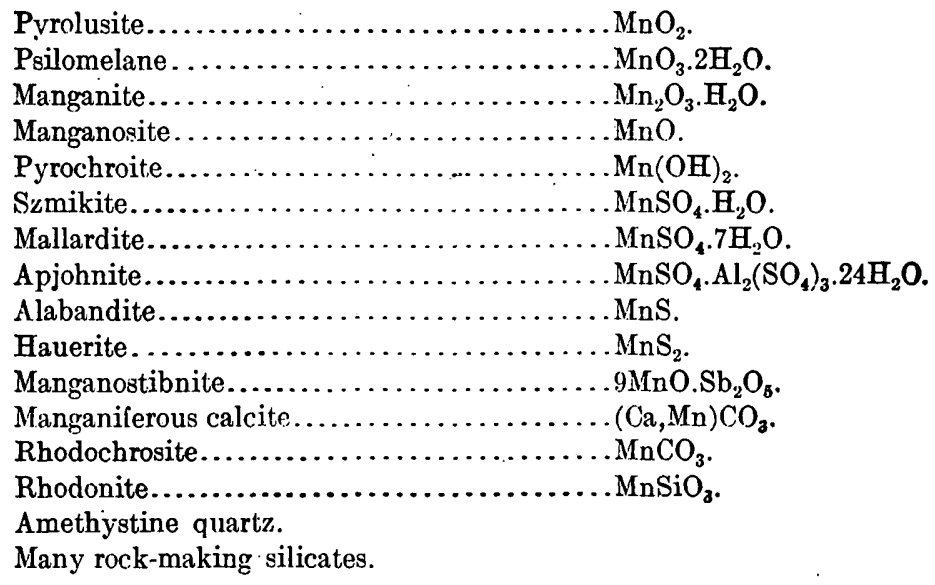

The commonest sources of manganese are probably the silicates of iron and magnesia. Manganese is more abundant in basic than in acidic rocks. The average of 1,038 determinations of igneous rocks ${ }^{1}$. is 0.10 per cent manganese protoxide $(\mathrm{MnO})$, while some contain more than 1.0 per cent.

Amethystine quartz is an important source of manganese in some auriferous deposits. It is an abundant gangue mineral at Creede, Colo., where it is the chief primary source of manganese. Some of the shipments of the ores from the Amethyst lode contain 3 or 4 per cent of manganese.

Rhodonite is closely allied to the pyroxenes in crystallization, but, unlike them, it occurs as a gangue mineral formed by ascending waters at moderate depths. It is found in ore of the Camp Bird, Tomboy, and other mines of the San Juan, Colo., in the silver-bearing veins of Butte, Mont., at Philipsburg, Mont., and at many other places.

Rhodochrosite is more common in mines of the United States than rhodonite. It is present in many veins of the San Juan, Colo., at Butte and Philipsburg, Mont., at Austin, Nev., and in many other western districts.

' Clarke, F. W., The data of geochemistry, 2d ed.: Bull. U. S. Geol. Survey No. 491, 1911, p. 27, 
Manganiferous calcite, an isomorphous compound of rhodochrosite and calcite, is a source of abundant manganese in many later Tertiary deposits in Nevada, Montana, and Colorado. It is probably present in certain Mesozoic copper deposits of Shasta County, Cal., where, according to Graton, ${ }^{1}$ wad occurs in the oxidized zone.

Rhodonite is considered primary in all its occurrences and rhodochrosite is deposited in the main from ascending hot solutions also, but in some occurrences it has been regarded as a secondary deposit from cold solutions.

Manganiferous precious-metal ores are in general deposited at moderate depths. Consequently they are common in middle or late Tertiary deposits of western North America but very rare indeed in contact-metamorphic deposits in the California gold veins and in deposits formed at equal or greater depths. ${ }^{2}$

The sulphates of manganese are soluble and do not accumulate in veins to any important extent; all are secondary. The oxides and hydrous oxides, which are very numerous, are the products of weathering of all manganese compounds. None of them are known to be deposited by ascending hot waters except near the orifices of hot springs.

The sulphides of manganese are exceedingly rare. Alabandite has been found in the gold mines of Nagyag, in Transylvania; at Gersdorf, near Freiberg, Saxony; on Snake River, Summit County, Colo.; at Tombstone, Ariz.; and at a few other places. Hauerite is still less common. I can find no record of its occurrence in the United States. The obvious explanation for the rarity of manganese sulphides in nature is their comparatively great solubility even in very dilute acids, and their tendency to oxidize on exposure to air.

PLACERS AND OUTCROPS.

Those deposits in which enrichment in gold is believed to have taken place are, almost without exception, manganiferous. Inasmuch as enrichment is produced by the downward migration of the gold instead of by its superficial removal and accumulation, it should follow that both gold placers and outcrops rich in gold would generally be found in connection with nonmanganiferous deposits; and this inference is believed to be confirmed by field observations. ${ }^{3}$ Placer deposits are in general associated with nonmanganiferous lodes, and such lodes are generally richer at the outcrops and in the oxidized

\footnotetext{
1 Graton, L. C., The occurrence of copper in Shasta County, Cal.: Bull. U. S. Geol. Survey No. 430, 1910 , p. 100.

2 Emmons, W. H., The agency of manganese in the superficial alteration and secondary enrichment of gold deposits in the United States: Bull. Am. Inst. Min. Eng. No. 46, 1910, pp. 813, 814-816.

${ }^{3}$ Idem, pp. 767-837; Jour. Geology, vol. 19, 1911, pp. 15-46.
} 
zones than in depth, the enrichment being due, in the main, to a removal of the material associated with gold. Even under favorable conditions, however, gold is generally dissolved less readily than copper or silver and precipitated more readily than either. Consequently its enriched ores are likely to be found nearer the surface. In a manganiferous calcite gangue gold may accumulate at the very outcrop, for the solutions could not long remain acid if passing through alkaline rocks. Some placer deposits even are associated with gold lodes having a manganiferous calcite gangue.

\section{CONCENTRATION IN THE OXIDIZED ZONE.}

The concentration of gold in the oxidized zone near the surface, where the waters remove the valueless elements more rapidly than gold, ${ }^{1}$ is an important process in lodes which do not contain manganese or in manganiferous lodes in areas where the waters do not contain appreciable chloride. In the oxidized zone in some mines it is difficult to distinguish the ore which has been enriched by this process from ore which has been enriched lower down by the solution and precipitation of gold and which, as a result of erosion, is now nearer the surface. It can not be denied that fine gold migrates downward in suspension, but this migration probably does not occur to an important extent in the deeper part of the oxidized zone. If the enrichment in gold is due simply to the removal of other constituents it is important to consider the volume relations and the mass relations before and after enrichment and to compare them with those now prevailing. It can be shown that the enriched ore in some lodes occupies about the same space that it occupied before oxidation. Let it be supposed that a pyritic gold ore has been altered to a limonite gold ore, and that gold has been neither removed nor added. Limonite (specific gravity 3.6 to 4), if it is pseudomorphic after pyrite (specfic gravity 4.95 to 5.10) and if not more cellular, weighs about 75 per cent as much as the pyrite. In those specimens which I have broken cellular spaces occupy in general about 10 per cent of the volume of the pseudomorph. With no gold added, the secondary ore should not be more than twice as rich as the primary ore, even if a large factor is introduced to allow for silica removed and for cellular spaces developed.

Rich bunches of ore are much more common in the oxidized zone than in the primary sulphides of such lodes. They are present in some lodes which carry little or no manganese in the gangue and which below the water level show no deposition of gold by descending solutions. Some of them are doubtless residual pockets of rich ore that were richer than the main ore body when deposited as sulphides,

1 Rickard, T. A., The formation of bonanzas in the upper portions of gold veins: Trans. Am. Inst. Min. Eng., vol. 31, 1902, pp. 198-220. 
but others are very probably ores to which gold has been added in the process of oxidation near the water table by the solution and precipitation of gold in the presence of the small amount of manganese contributed by the country rock. In view of the relations shown by the chemical experiments it is probable that a very little manganese will accomplish the solution of gold, but it requires considerably more manganese to form appreciable amounts of the higher manganese compounds that delay the deposition of gold, suppressing its precipitation by ferrous sulphate. In the absence of larger amounts of the higher manganese compounds the gold would probably be precipitated almost as soon as the solutions encountered the zone where any considerable amount of pyrite or other sulphides was exposed in the partly oxidized ore; for oxygenated solutions dissolve pyrite, and even traces of the ferrous sulphate formed in the oxidizing reactions precipitate gold almost immediately. Many other sulphides precipitate gold very readily. From this it follows that deposits showing only traces of manganese, presumably supplied from the country rock, are not enriched far below the zone of oxidation.

\section{VERTICAL RELATION OF DEEP-SEATED ENRICHMENT IN GOLD TO CHALCOCITIZATION.}

In several of the great copper districts of the West gold is a valuable by-product. In another group of deposits, mainly of Tertiary age and younger than the copper deposits, silver and gold are the principal metals, and copper, when present, is only a by-product. But in some of these precious-metal ores chalcocite is nevertheless the most abundant metallic mineral and constitutes several per cent of the vein matter. In many ores it forms a coating over pyrite or other minerals: Some of this ore, appearing in general not far below the water table, is fractured, spongy quartz coated with pulverulent chalcocite. A part of it contains a good deal of silver and more gold than the oxidized ore or the deeper-seated sulphide ore. Clearly the conditions that favor chalcocitization are favorable also to the precipitation of silver and gold.

The replacement of pyrite by chalcocite is, according to Stokes, ${ }^{1}$ as follows:

$$
5 \mathrm{FeS}_{2}+14 \mathrm{CuSO}_{4}+12 \mathrm{H}_{2} \mathrm{O}=7 \mathrm{Cu}_{2} \mathrm{~S}+5 \mathrm{FeSO}_{4}+12 \mathrm{H}_{2} \mathrm{SO}_{4} .
$$

This reaction is considered by Spencer ${ }^{2}$ as comprising several stages, which may be indicated as follows:

$$
\begin{aligned}
& 2 \mathrm{FeS}_{2}+2 \mathrm{CuSO}_{4}=\mathrm{Cu}_{2} \mathrm{~S}+2 \mathrm{FeSO}_{4}+\mathrm{S} . \\
& 3 \mathrm{~S}+2 \mathrm{CuSO}_{4}=\mathrm{Cu}_{2} \mathrm{~S}+4 \mathrm{SO}_{2} . \\
& 6 \mathrm{H}_{2} \mathrm{O}+5 \mathrm{SO}_{2}+2 \mathrm{CuSO}_{4}=\mathrm{Cu}_{2} \mathrm{~S}+6 \mathrm{H}_{2} \mathrm{SO}_{4} .
\end{aligned}
$$

\footnotetext{
I Stokes, H. N., Experiments on the action of various solutions of pyrite and marcasite: Econ. Geology, vol. 2, 1907, p. 22.

s Spencer, A. C., Chalcocite deposition: Jour. Washington Acad. Scl., vol. 3, 1913, p. 73.
} 
The reactions may differ as to details, but without much doubt ferrous sulphate and acid are set free. Attendant reactions confirm this statement, for if calcite is present gypsum is formed by the reaction of sulphuric acid on lime carbonate, and if the wall rocks are sericitic kaolin is formed by the reaction of the acid with potassiumaluminum silicate, the potash going into solution as sulphate. The abundant ferrous sulphate must quickly drive the gold from solution, and it apparently follows that there may be no appreciable enrichment of gold below the zone where chalcocitization is the prevailing process. In deposits like disseminated chalcocite in porphyry, where the chalcocite occurs in flat-lying zones conforming with the present surface, where the ore from which chalcocite was derived carried gold, and where suitable solvents were provided, the gold, at least in the upper part of the chalcocite zone, should be rather evenly distributed and should increase and decrease in quantity with the chalcocite of the secondary ore. According to report there is a fairly constant ratio between copper and gold in the disseminated deposits at Ely, Ner., and Bingham, Utah. In the copper deposits at Rio Tinto, Spain, ${ }^{1}$ the secondary ores between the gossan and the primary sulphides carried high values in gold and silver. In view of the chemical relations it would appear that whatever gold and silver are present below a chalcocitized pyrite ore are, without much doubt, primary.

Gold and silver are commonly associated in their deposits, and an exact knowledge of the solution and precipitation of the two metals in experiments where both are present would have great practical value. Although gold is dissolved in chloride solutions, silver chloride is but slightly soluble, and high concentration of the two metals could not exist in the same solution. There is so little exact information regarding the solubilities of gold chloride and silver chloride in solutions containing both metals that a discussion of their relations is little more than speculation, yet certain data should be considered in this connection. Silver chloride is slightly soluble in water, and silver may be held in small concentration in solutions in which gold also is dissolved. A mine water from the Comstock lode, according to Reid, ${ }^{2}$ carried 188 milligrams of silver and 4.15 milligrams of gold in a ton of solution. Since ferrous sulphate and certain sulphides precipitate both gold and silver from acid solution, alloys of these metals might form as secondary minerals. Since ferrous sulphate is released in the chalcocitization of pyrite, the secondary ores of gold and silver could be deposited simultaneously with chalcocite.

\footnotetext{
1 Vogt, J. H. L., Problems in the geology of ore deposits, in Pošepny, Franz, The genesis of ore deposits, 1902 , p. 676.

2 Reid, J. A., The structure and genesis of the Comstock lode: Bull. Dept. Geology Univ. California, vol. 4, No. 10, 1905, p. 193.
} 
GOLD AND SILVER TELLURIDES.

Petzite, sylvanite, krennerite, and calaverite are tellurides of gold and silver, the precious metals being present in varying proportions. All are regarded as primary. Since hydrogen telluride $\left(\mathrm{H}_{2} \mathrm{Te}\right)$ is made by the action of acids on metallic tellurides, and since gold and silver tellurides are insoluble, ${ }^{1}$ telluride enrichment appears to be within the bounds of probability, but no clearly defined examples of secondary gold-silver tellurides are known to me.

SOME CHEMTCAL RELATIONS AND MINERALS OF LEAD.

PRINCIPAL LEAD MINERALS.

The chemical composition of the principal lead minerals is given below:

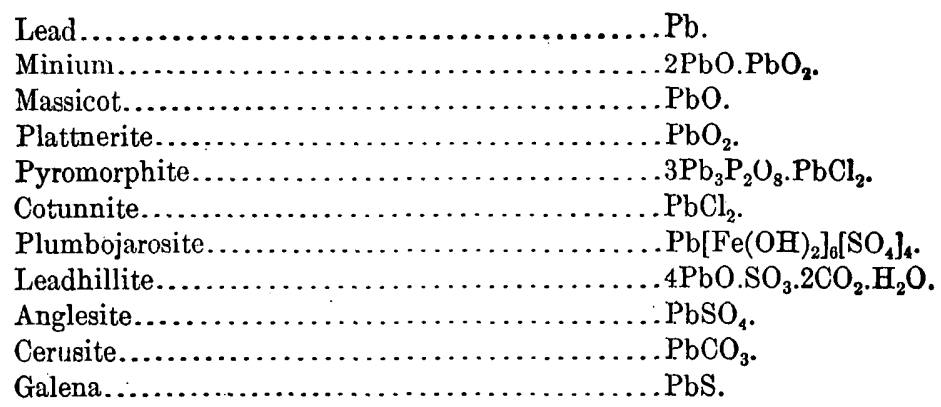

SOLUBILITIFS OF LEAD COMPOUNDS.

The solubilities of several lead compounds, as determined by Kohlrausch, are as follows:

\begin{tabular}{|c|c|c|c|}
\hline $\mathrm{PbSO}_{4}$ & $\mathrm{PbCl}_{2}$ & $\mathrm{PbCO}_{3}$ & $\mathrm{~Pb}\left(\mathrm{NO}_{3}\right)_{2}$ \\
\hline $\begin{array}{c}\mathbf{0 . 0 4 1} \\
.00013\end{array}$ & $\begin{array}{r}14.9 \\
.05\end{array}$ & $\begin{array}{r}\mathbf{0 . 0 0 1} .00003 \\
.0616 .6 \\
\mathbf{1 . 4}\end{array}$ \\
\hline
\end{tabular}

The upper number in each column shows the number of grams of the anhydrous salt held in solution in a liter of water at $18^{\circ} \mathrm{C}$; ; the lower number shows the molar solubility or the number of mols contained in a liter of the saturated solution. ${ }^{2}$

The common salts of lead are bivalent; the rarer ones are quadrivalent. As shown by the table above, all the common salts have low solubilities except the nitrates, which are not important in processes of sulphide enrichment. Freshly precipitated lead sulphide is dissolved sparingly in cold water, its solubility being $0.0000036 \mathrm{~mol}$ in a liter. (See p. 57.)

1 Smith, Alexander, Introduction to inorganic chemistry, rev. ed., 1910, p. 403. 2Idem, p. 544. 
The native metal and the oxides of lead (minium, plattnerite, and massicot) are of rare occurrence.

Lead chloride is moderately soluble, so cotunnite, $\mathrm{PbCl}_{2}$, does not accumulate in the oxidized zones of lead deposits. Lead chlorophosphate, pyromorphite, is much more common. Lead carbonate is very sparingly soluble, so cerusite, $\mathrm{PbCO}_{3}$, is a comparatively stable mineral, as is the sulphate, anglesite, $\mathrm{PbSO}_{4}$. Although the solubility of the sulphate is low, it is nevertheless appreciable, as is indicated in quantitative analysis, for in order to prevent loss a precipitate of lead sulphate formed in sulphuric acid is washed with alcohol rather than with water. The transfer of lead as sulphate in small yet appreciable quantities was shown also in the experiments of Buehler and Gottschalk (p. 49).

As would be supposed from consideration of the relatively low solubility of its sulphate, lead is not extensively transferred in cold a'cid sulphate waters. R. C. Wells has shown that galena reacts with weak solutions of sulphuric acid more readily than pyrite or chalcopyrite, the reaction being attended by the liberation of hydrogen sulphide (p. 59). Whether oxygen is necessary for the solution of lead sulphide, as it is for the solution of copper sulphide, I am unable to state. The salts that form under natural conditions have low solubilities and coat the sulphides, inhibiting or at least retarding further action. Consequently lead sulphide dissolves slowly. It is dissolved in acid to only a slight extent and, like copper sulphide, would be deposited in an acid environment. Although several primary minerals contain lead, ${ }^{1}$ galena is the only one of these that is at all common. All the other minerals listed above-the chlorides, oxides, sulphates, and carbonates-are probably formed as secondary minerals only.

The paragenetic evidence that galena is commonly precipitated below the water level by the reduction of acid sulphate waters is not abundant, but in the greater number of its occurrences galena is regarded as primary. Lead, like gold, migrates very slowly in cold solutions.

\section{OCCURRENCE OF THE LEAD MINERALS.}

Native lead.-Although native lead is found in a number of lead deposits, ${ }^{2}$ it is in very few so abundant as to become an important ore mineral. It is probably formed by reduction of oxygen salts of lead.

Pyromorphite, $3 \mathrm{~Pb}_{3} \mathrm{P}_{2} \mathrm{O}_{8} \cdot \mathrm{PbCl}_{2}$, is the principal metallic phosphate and is the only common lead mineral containing chlorine. It is an alteration product of lead ores that are exposed to waters carrying

1 Clarke, F. W., The data of geochemistry, 2d ed.: Bull. U. S. Geol. Survey No. 491, 1911, p. 645.

2 Hintze, Carl, Handbuch der Mineralogie, vol. 1, pp. 333-334. 
chlorine and phosphoric acid. At Philipsburg, Mont., at Creede, Colo., and in the Cœur d'Alene district, Idaho, ${ }^{1}$ pyromorphite is characteristic of upper parts of the zones of oxidation. In these deposits it is associated with limonite and commonly carries silver, possibly as finely divided cerargyrite.

Cotunnite, $\mathrm{PbCl}_{2}$, as already stated, is a comparatively rare mineral. It has been identified at few places, one of them in the crater of Vesuvius. Lead chloride is more soluble than lead chlorophosphate. The accumulation of the chloride in the oxidized zones of lead deposits is limited probably by the amount of phosphate available in the natural solutions.

Minium, massicot, and plattnerite, all oxides of lead, are comparatively rare. All are secondary.

Leadhillite, $4 \mathrm{PbO} \cdot \mathrm{SO}_{3} \cdot 2 \mathrm{CO}_{2} \cdot \mathrm{H}_{2} \mathrm{O}$, a basic sulphatocarbonate of lead, is found in ores altered by surface agencies and is probably confined to such deposits.

Anglesite, $\mathrm{PbSO}_{4}$, is known only as an alteration product. Most commonly it forms from galena, but it has been noted also as an alteration product of guitermanite, ${ }^{2}$ an arsenic sulphide of lead, and also of other minerals. According to Penrose, ${ }^{3}$ the sulphate forms as an intermediate product when galena is altered to cerusite, and at Leadville, Colo., S. F. Emmons ${ }^{4}$ found that thin crusts of anglesite occurred between galena and the crust of carbonate which enveloped it. It is associated with carbonates and sulphide in oxidized zones of deposits at Bingham, Utah. ${ }^{5}$ Boutwell describes an interesting specimen consisting of a kernel of galena covered with anglesite, which in turn is coated with cerusite, upon which is deposited yellow lead oxide, probably massicot. In the sideritic lead ores of the Cœur d'Alene district, Idaho, according to Ransome, ${ }^{6}$ no anglesite has been detected, but the carbonate appears to form without the intermediate sulphate.

Anglesite is much more common than cerusite in the oxidized lead ores of Lake City, Colo., ${ }^{7}$ and is of considerable economic value in this district. In the upper 100 feet of the Moro vein it is particularly abundant. It is common also in the lead ores at Creede, Colo. ${ }^{8}$

\footnotetext{
1 Ransome, F. L., and Calkins, F. C., The geology and ore deposits of the Cœur d'Alene district, Idaho: Prof. Paper U. S. Geol. Survey No. 62, 1908, p. 103.

2 Ransome, F. L., A report on the economic geology of the Silverton quadrangle, Colo.: Bull. U. S. Geol. Survey No. 182, 1901, p. 87.

8 Penrose, R. A. F., Superficial alteration of ore deposits: Jour. Geology, vol. 2, 1894, p. 297.

4 Emmons, S. F., Geology and mining industry of Leadville, Colo.: Mon. U. S. Geol. Survey, vol. 12, 1886, p. 546 .

5 Boutwell, J. M., Economic geology of the Bingham mining district, Utah: Prof. Paper U. S. Geol. Survey No. 38, 1905, p. 113.

- Ransome, F. L., and Calkins, F. C., op. cit., p. 132.

I Irving, J. D., and Bancroft, Howland, Geology and ore deposits near Lake City, Colo.: Bull. U. S. Geol. Survey No. 478, 1911, p. 61.

8 Emmons, W. H., and Larsen, E. S., Geology and ore deposits of Creede, Colo.: Bull. U. S. Geol. Survey (in proparation).
} 
Cerusite, $\mathrm{PbCO}_{3}$, is unknown as a primary mineral but is common as an alteration product. It was abundant in the upper levels of mines at Bingham, Utah, where it was generally associated with anglesite and galena. ${ }^{2}$ It is an important ore mineral of the deposits at Leadville, ${ }^{2}$ in some veins of the Cœur d'Alene district, ${ }^{3}$ at Creede, and in several other lead-ore districts. It is most abundant in deposits where the country rock is limestone but is not limited to such deposits. Very commonly the carbonate replaces galena metasomatically. According to Penrose ${ }^{4}$ lead sulphate may form intermediately between the sulphide and carbonate, and its formation is favored by the lower solubility of the carbonate. (See p. 135.) In the Cœur d'Alene district the change is not everywhere a metasomatic replacement for, according to Ransome, ${ }^{5}$ cerusite is common in little vugs or crevices in the sulphides, where it is formed on unaltered galena by solutions that have percolated downward from the oxidized zone. As stated by Ransome, the oxidation of siderite may supply carbonate for cerusite. The reaction is-

$$
4 \mathrm{FeCO}_{3}+3 \mathrm{H}_{2} \mathrm{O}+\mathrm{O}_{2}=\mathrm{Fe}_{2}(\mathrm{OH})_{6} \mathrm{Fe}_{2} \mathrm{O}_{3}+4 \mathrm{CO}_{2} \text {. }
$$

With carbonic àcid in solution cerusite may form as follows:

$$
\mathrm{PbSO}_{4}+\mathrm{H}_{2} \mathrm{CO}_{3}=\mathrm{PbCO}_{3}+\mathrm{H}_{2} \mathrm{SO}_{4} \text {. }
$$

Galena, $\mathrm{PbS}$, is a "persistent" mineral-a mineral formed under many natural conditions. The most important deposits of galena in the United States are the disseminated ores of southeastern Missouri and the lead-silver ores of the Cœur d'Alene district, Idaho. ${ }^{6}$ The galena in Missouri is nearly pure lead sulphide, has a perfect cleavage, and is generally in cubic crystals; the galena of the Cour d'Alene district contains appreciable silver, is generally not so well crystallized, and has a much less perfect cleavage, so that a freshly broken fracture resembles that of steel and the mineral is called "steel galena" by the miners. Some antimonial galena has a similar fracture. Some galena is rich in silver, which is probably present as finely divided argentite, $\mathrm{Ag}_{2} \mathrm{~S}$.

The stability of galena in the oxidized zone has already been mentioned. The relative insolubility of galena in natural waters is shown by the experiments of Buehler and Gottschalk (p. 49), and is confirmed abundantly by observations in the oxidized zones of deposits. Galena is commonly found in sluice boxes of placer mines

1 Boutwell, J. M., Economic geology of the Bingham mining district, Utah: Prof. Paper U. S. Geol. Survey No. 38, 1905, p. 112.

2 Emmons, S. F., Geology and mining industry of Leadville, Colo.: Mon. U.S. Geol. Survey, vol. 12, 1886, p. 546 .

8 Ransome, F. L., and Calkins, F. C., op. cit., p. 92.

4 Penrose, R. A. F., Superficial alteration of ore deposits: Jour. Geology, vol. 2, 1894, p. 297.

6 Ransome, F. L., and Calkins, F. C., op. cit., p. 112.

- Idem, p. 91. 
and is plowed up in the fields of the southwestern Wisconsin zinc district. Even in districts where the climate is comparatively moist, such as the Breckenridge and Cœur d'Alene districts, galena is found at the very outcrops of some ore veins. ${ }^{1}$

In the Cœur d'Alene district, according to Ransome and Calkins, there is little evidence of enrichment of either silver or lead by cold solutions. In the Breckenridge district ${ }^{2}$ the characteristic ore of the upper levels is argentiferous galena, more or less altered to cerusite, whereas in the lower levels sphalerite and pyrite become increasingly abundant, suggesting enrichment in the upper levels by addition of lead or by subtraction of zinc, or by both.

At Leadville, Colo., according to Blow, ${ }^{3}$ stringers of galena rich in silver penetrate the limestone below the bodies of carbonate ores. As noted by Vogt,, and also by Finlayson, ${ }^{5}$ the pyritic ore of the Rio . Tinto mine in Spain is cracked and is generally seamed with deposits of chalcocite, bornite, chalcopyrite, and galena, and the galena, according to Finlayson, is commonly of most recent formation. It is not stated, however, that the galena was deposited by descending waters.

Weed ${ }^{8}$ has described secondary galena from the sulphide zone at Neihart, Mont., where it is associated with zinc blende and incrusted with polybasite; and Irving and Bancroft ${ }^{7}$ state that some of the galena of the Lake City district, Colorado, is without doubt connected genetically with oxidation processes. In that district a gray coating of a lead compound, thought to be galena, occurs in cracks of shattered sphalerite and covers its exposed surfaces. Possibly the gray sphalerite observed in many deposits of the West owes its color to such a veneer of galena.

A survey of the literature of lead deposits for examples giving evidence of considerable secondary precipitation of lead sulphide in lode ores has not been very fruitful of results. On the other hand, there is much evidence of migration of lead in cold carbonated solution and of its precipitation as sulphide in the important lead and zinc ores of the Mississippi Valley. These processes, as already stated, do not come within the scope of this investigation.

1 Ransome, F. L., Geology and ore deposits of the Breckenridge district, Colorado: Prof. Paper U. S. Geol. Survey No. 75, 1911, p. 166. Ransome, F. L., and Calkins, F. C., Geology and ore deposits of the Cœur d'Alene district, Idaho: Prof. Paper U. S. Geol. Survey No. 62, 1908, p. 133.

2 Ransome, F. L., Criteria of downward sulphide enrichment: Econ. Geology, vol. 5, 1910, p. 206.

${ }^{3}$ Blow, A. A., The ore chutes and recent developments of Iron Hill, Leadville, Colo.: Trans. Am. Inst. Min. Eng., vol. 18, 1890, p. 169.

4 Vogt, J. H. L., Das Huelva-Kiesfeld: Zeitschr. prakt. Geologie, July, 1899, p. 249.

$\checkmark$ Finlayson, A. M., The pyritic deposits of Huelva, Spain: Econ. Geology, vol. 5, 1910, p. 421.

- Weed, W. H., The enrichment of gold and silver veins, in Pošepný, Franz, The genesis of ore deposits, 1902, p. 485.

I Irving, J. D., and Bancroft, Howland, Geology and ore deposits near Lake City, Colo.: Bull. U. S. Geol. Survey No. 478, 1911, p. 97. 
SOME CHEMICAL RELATIONS AND MINERALS OF ZINC.

\section{PRINCIPAL ZINC MINERALS.}

The chemical composition of the principal zinc minerals is shown below:

Goslarite.................... $\mathrm{ZnSO}_{4} .7 \mathrm{H}_{2} \mathrm{O}$.

Smithsonite................... $\mathrm{ZnCO}_{3}$.

Calamine..................... $\mathrm{Zn}_{2} \mathrm{H}_{2} \mathrm{SiO}_{5}$ or $2 \mathrm{ZnO} \cdot \mathrm{SiO}_{4} \cdot \mathrm{H}_{2} \mathrm{O}$.

Willemite................... $\mathrm{Zn}_{2} \mathrm{SiO}_{4}$.

Hydrozincite.................. $\mathrm{ZnCO}_{3} .2 \mathrm{ZnO}_{2} \mathrm{H}_{2}$ or $3 \mathrm{ZnO} . \mathrm{CO}_{2} \cdot 2 \mathrm{H}_{2} \mathrm{O}$.

Aurichalcite................... $2(\mathrm{Zn}, \mathrm{Cu}) \mathrm{CO}_{3} \cdot 3(\mathrm{Zn}, \mathrm{Cu}) \mathrm{O}_{2} \mathrm{H}_{2}$.

Sphalerite....................

Wurtzite.................... ZnS.

SOLUBILITIES OF ZINC COMPOUNDS.

The solubilities of several zinc salts determined by Kohlrausch are stated below:

\begin{tabular}{|c|c|c|c|}
\hline $\mathrm{ZnSO}_{4}$. & $\mathrm{ZnCl}_{3}$. & $\mathrm{ZnCO}_{3}$ & $\mathrm{Zn}\left(\mathrm{NO}_{3}\right)_{2}$ \\
\hline $\begin{array}{r}531.2 \\
3.1\end{array}$ & $\begin{array}{l}2039 . \\
9.2\end{array}$ & $\begin{array}{l}0.04 ? \\
.0003 ?\}\end{array}$ & $\begin{array}{l}1178 . \\
4.7\end{array}$ \\
\hline
\end{tabular}

The upper number in each column shows the number of grams of the anhydrous salt held in solution in a liter of water at $18^{\circ} \mathrm{C}$; the lower number shows the molar solubility or the number of mols contained in a liter of the saturated solution.

Zinc is bivalent in all its compounds. The sulphate and chloride are very soluble and the carbonate is more soluble than carbonate of lead. A liter of pure water dissolves at ordinary temperature and pressure $0.0000706 \mathrm{~mol}$ of freshly precipitated zinc sulphide. (See p. 59.) The principal primary zinc mineral is the isometric form, sphalerite. Wurtzite, the hexagonal form of zinc sulphide, is comparatively rare. In some occurrences the primary zinc minerals are oxides, such as franklinite, zincite, and gahnite, but as these are rare or absent in sulphide deposits, they are not considered here.

As zinc sulphide is easily dissolved in sulphuric acid sphalerite would not form in a highly acid solution. If, through reactions with the wall rock, the solution should become feebly acid or neutral, then zinc sulphide could be precipitated. Allen and Crenshaw state that sphalerite is precipitated from acid as well as from alkaline solutions, but that wurtzite is precipitated only from acid solutions and is probably always secondary. ${ }^{1}$ Since zinc sulphide is one of the most soluble of the common sulphides it could not replace sulphides of

\footnotetext{
1 Allen, E. T., and Crenshaw, J. L., The sulphides of zinc, cadmium, and mercury; their crystalline
} forms and genetic conditions: Am. Jour. Sci., 4th ser., vol. 34, 1912, p. 359. 
copper, silver, or lead. Possibly it could replace pyrite, marcasite, or pyrrhotite under certain conditions, but no examples of its pseudomorphs after these minerals are known to me. It is itself replaced by chalcocite and covellite and probably by argentite and galena.

There is every reason to suppose that zinc sulphide in carbonate rocks in the zinc deposits of the upper Mississippi Valley in southwestern Wisconsin has been dissolved by oxygenated. waters and has been reprecipitated as sulphide in large amounts where the solutions were in contact with reducing agents.

Secondary zinc blende has been found in western ore deposits in other than limestone, but so far as the records show its occurrence in western deposits is exceedingly rare. Large quantities of zinc are undoubtedly dissolved from the outcrops and oxidized zones of deposits in which it occurs as sulphide and are passed as sulphate downward, below the water level. To account for its disposition is one of the most perplexing problems in the study of mineral genesis. Doubtless much of it escapes to the surface and is scattered, yet many analyses of waters issuing from zinc deposits show much less zinc than would be expected. In two alkaline waters from sphaleritic deposits of Creede, Colo., no zinc is reported. In waters from several other deposits it is present in considerable amounts, but the quantity of it found in some of these is less than would be expected. In waters from several deposits at Ducktown, Tenn., the zinc in solution is less than the copper, although the sulphide deposits contain as much zinc as copper and copper is now being precipitated. Some sludges deposited by mine waters where they issue to the air contain considerable zinc; others contain practically none. Zinc salts do not hydrolyze so readily as ferric salts when exposed to air. With carbon dioxide they form smithsonite, hydrozincite, and aurichalcite, but these compounds are generally less abundant than hydrous iron oxide.

\section{OCCURRENCE OF THE ZINC MINERALS.}

Goslarite, hydrated zinc sulphate, occurs on the walls of some mine workings as a white filiform or mosslike efflorescence, which soon disintegrates to powder in the air. Owing to the high solubility of zinc sulphate in water, goslarite is comparatively rare in most districts, though it is abundant in some, as at Creede, Colo., and Butte, Mont. Weed states that zinc sulphate is carried by the moisture of the air circulating in mine openings. ${ }^{1}$

Zinc chloride is even more soluble than the sulphate and is unknown as a natural mineral.

Smithsonite, $\mathrm{ZnCO}_{3}$, is commonly found in the oxidized zones of zinc-bearing veins. It is most abundant in deposits in limestone.

I Weed, W. H., Geology and ore deposits of the Butte district, Montans: Prof. Paper U. S. Geol. Survey No. 74, 1912, p. 99. 
It has not been reported as a primary mineral in deposits formed by hot ascending waters. Where zinc-sulphate waters attack limestone, smithsonite is deposited, calcium sulphate, the most soluble salt, going into solution. The reaction may be stated as follows:

$$
\mathrm{ZnSO}_{4}+\mathrm{CaCO}_{3}+2 \mathrm{H}_{2} \mathrm{O}=\mathrm{CaSO}_{4} \cdot 2 \mathrm{H}_{2} \mathrm{O}+\mathrm{ZnCO}_{3} .
$$

The calcium sulphate precipitated as gypsum may remain with smithsonite or may be carried away in solution, since it is fairly soluble in cold water $\left(2.0\right.$ grams in a liter at $18^{\circ} \mathrm{C}$.).

Calamine, $\mathrm{H}_{2} \mathrm{Zn}_{2} \mathrm{SiO}_{5}$, is commonly associated with smithsonite in the oxidized zones of zinciferous ores. It is not known as a primary mineral of ore veins deposited from hot solutions.

Willemite, $\mathrm{Zn}_{2} \mathrm{SiO}_{4}$, the anhydrous silicate, is much less common than calamine. It is abundant in the primary ores of Franklin Furnace, N. J., ${ }^{1}$ but is not reported as occurring in the secondary ores at many zinc deposits. It is noted as an alteration product, however, at Morenci, Ariz., ${ }^{2}$ and appears in considerable quantities at Tres Hermanas, N. Mex., ${ }^{3}$ where it is probably derived from zinc blende by oxidation.

Hydrozincite, the basic carbonate, occurs commonly in altered ores. Aurichalcite, a basic carbonate of zinc and copper, is deposited by cold solutions, generally as drusy incrustations.

Sphalerite is the most abundant primary ore of zinc. A few observations on the occurrence of secondary sphalerite are noteworthy. According to Blow, ${ }^{4}$ it seems probable that at Leadville, Colo., a large proportion of the zinc removed from the carbonate zone by surface waters was redeposited as sulphide in the lodes just below the line of complete oxidation and that redeposition has kept pace with oxidation. In Shasta County, Cal., according to Graton, ${ }^{5}$ sphalerite that is later than pyrite is found in the sulphide zones of copper deposits in association with minerals that are probably in part of secondary origin. Veinlets of sphalerite cut rhodochrosite ore at Philipsburg, Mont. At Rio Tinto, according to Finlayson, ${ }^{6}$ some sphalerite is later than pyrite and chalcopyrite. At Breckenridge, Colo., according to Ransome, ${ }^{7}$ some of the sphalerite is younger than the earliest period of deposition, although it can not be shown that it is a deposit of sulphate water. There is not much evidence, however, that zinc

I Spencer, A. C., Franklin Furnace folio (No. 161), Geol. Atlas U. S., U. S. Geol. Survey, 1908.

2 Lindgren, Waldemar, The copper deposits of the Clifton-Morenci district, Arizona: Prof. Paper U:S. Geol. Survey No. 43, p. 111.

${ }^{3}$ Lindgren, Waldemar, Graton, L. C., and Gordon, C. H., The ore deposits of New Mexico: Prof. Paper U. S. Geol. Survey No. 68, 1911, p. 294.

-Blow; A. A., The ore chutes and recent developments of Iron Hill, Leadville, Colo.: Trans. Am. Inst. Min. Eng., vol. 18, 1890, p. 172.

Graton, L. C., The occurrence of copper in Shasta County, Cal.: Bull. U. S. Geol. Survey No. 430, 1910, pp. 71-111.

- Finlayson, A. M., The pyritic deposits of Euelva, Spain: Econ. Geology, vol. 5, 1910, p. 417.

7 Ransome, F. L., Geology and ore deposits of the Breckenridge district, Colo.: Prof. Paper U. S. Geol. Survey No. 75, 1911, p. 169. 
blende is precipitated as a secondary mineral along with copper, silver, and gold.

Wurtzite is probably a secondary mineral in the San Francisco district, Utah, according to B. S. Butler. In this connection the recent experiments of E. T. Allen and J. L. Crenshaw at the Carnegie Geophysical Laboratory are suggestive. Zinc sulphide was precipitated as wurtzite in acid but not in alkaline solutions.

\section{SOME CHEMICAL RELATIONS AND MINERALS OF IRON.}

PRINCLPAL IRON MINERALS.

The chemical composition of the principal iron minerals is shown below:

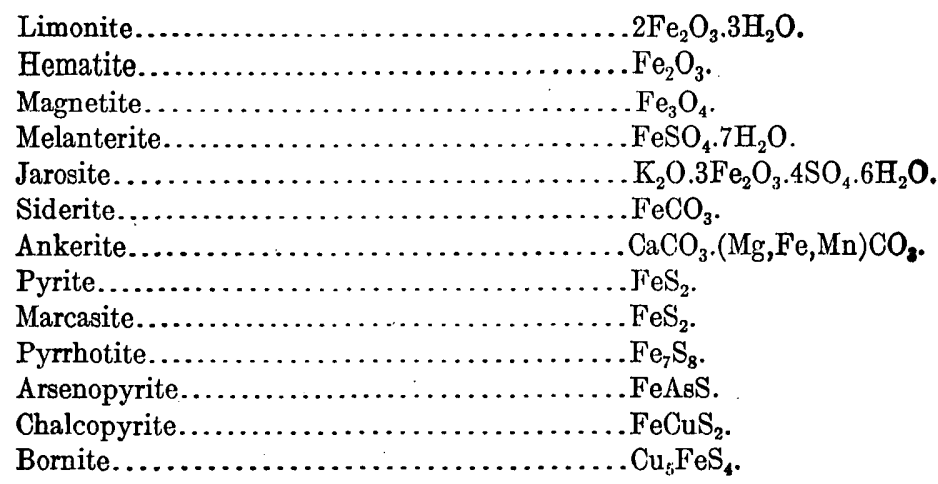

SOLUBILITIES OF IRON SALTS.

No comprehensive table showing the solubilities of iron salts determined under similar conditions is available to me. The solubilities of ferric and of ferrous salts differ greatly, and the experimental difficulties in determining the solubilities are considerable, owing to the changes that take place in the state of oxidation of iron. According to Atherton Seidell, ${ }^{1}$ a liter of water at $20^{\circ}$ C. dissolves 264.2 grams $\mathrm{FeSO}_{4} .7 \mathrm{H}_{2} \mathrm{O}$; a liter of water saturated with $\mathrm{CO}_{2}$ dissolves, at 6 to 8 atmospheres, 0.73 gram $\mathrm{FeCO}_{3}$; a liter of water at $15^{\circ} \mathrm{C}$. dissolves 400 grams of $\mathrm{FeCl}_{2} \cdot 4 \mathrm{H}_{2} \mathrm{O}$ (Etard); a liter of water'at $20^{\circ}$ C. dissolves 478.8 grams $\mathrm{FeCl}_{3}$. (Total $\mathrm{FeCl}_{3} \cdot 12 \mathrm{H}_{2} \mathrm{O}$ is 918.5 grams.)

\section{NATURE AND RELATIONS OF THE IRON MINERALS.}

Iron sulphides are comparatively unimportant as ores of iron. Some of the cinder obtained from burning pyrite for making acid is utilized in blast furnaces, and the gossans of some iron sulphide deposits also are smelted, but few of the iron ores of commerce are associated with sulphide deposits. The iron sulphides nevertheless

1 Seidell, Atherton, Solubilities of inorganic and organic substances, New York, 1911. 
play a most important part in the alteration and enrichment of deposits of the more valuable metals, and it is in that connection that they are considered here.

Most mine waters contain iron, and the facility with which ferric sulphate is changed to ferrous sulphate affords the most readily available index to the state of oxidation of the solutions. The chemical processes involved in the alteration of iron sulphides, the reduction of ferric sulphate, and the removal of acid to form inert sulphates below the water level have already been discussed.

Most of the iron sulphides contain more than enough sulphur to form iron sulphate on oxidation, and the remaining sulphate may be utilized to form sulphuric acid. Ferric sulphate readily hydrolyzes, forming basic ferric sulphate and subsequently ferric hydroxide, and each step sets free sulphuric acid. The property of hydrolysis of ferric salts is most important in connection with the superficial alteration and the enrichment of sulphide ores. It supplies a solvent for most of the metals; it generally results in the concentration of iron oxide at the surface, which may afford an indication that a deposit containing iron sulphide is below.

One function of basic ferric sulphate, which ultimately breaks down to form oxide, is to supply sulphate ion to solutions in the oxidized zone. Sulphates may thus be available even after all sulphides have disappeared.

As a result of the hydrolyzation of ferric sulphate the larger portion of the iron is generally fixed near the surface as iron oxide. Not all is so fixed, however, for the analyses of mine waters show that iron is almost universally present in the underground circulation. It has been stated above that iron passes below the water level, held in sulphuric acid solution mainly as iron sulphate; that the sulphate solution reacts on sulphides and gangue minerals; and that the acidity is reduced by forming inert sulphates, chiefly those of alkalies and alkaline earths. Along with such changes in acidity ferrous sulphate is produced by reduction of ferric sulphate.

It is doubtful whether ferric sulphate exists to any great extent far below the water level. In air a decrease in acidity favors hydrolyzation, but below the water level, where air is excluded, the decrease in acidity is attended by reduction of iron to ferrous state. Ferrous sulphate does not hydrolyze to precipitate iron oxide. Ferrous hydrate may be formed in neutral or alkaline environment. It is a light-colored salt which unites rapidly with free oxygen to form the brown ferric hydroxide. The mixture has a greenish appearance when distributed in a finely divided state through the precipitate. ${ }^{1}$

In little cracks in sulphide ore, at considerable depths below the highly oxidized zone, small veinlets and putty-like masses of an

1 Ostwald, Wilhelm, The principles of inorganic chemistry (trans. by Alex. Findlay), London, 1904, p. 577. 
iron oxide that is generally assumed to be limonite are conspicuous in many deposits. Such deposits of iron oxides in the GraniteBimetallic vein at Philipsburg, Mont., are at least 500 feet below the zone of the highly oxidized ore. Some of them doubtless have formed since the mine was opened, at places where iron sulphate solutions issued from the vein and came in contact with air. Others may be due to deposition of iron oxide or basic ferric sulphate from suspension. (See pp. 73, 110.) Possibly some are the oxidation products of ferrous sulphate.

E. T. Allen has shown that a solution of hydrogen sulphide and ferric sulphate gives ferrous sulphate and sulphur, and in cold solutions of very low acidity ferrous sulphate with sulphur and hydrogen sulphide gives $\mathrm{FeS}_{2}$ as pyrite and marcasite, the amount of each depending somewhat upon the acidity of the solution. It has been shown above that these conditions probably exist in the deeper zones in some deposits, but almost certainly they exist through a comparatively narrow chemical range. Consequently, the precipitation of secondary iron sulphides, although known in some, is probably subordinate in most deposits. Secondary chalcopyrite has been discussed with the ores of copper.

\section{OCCURRENCE OF THE IRON MINERALS.}

Limonite, $2 \mathrm{Fe}_{2} \mathrm{O}_{3} \cdot 3 \mathrm{H}_{2} \mathrm{O}$, is generally the most abundant of the iron oxides of the altered zones, which are mainly but not altogether hydrated oxides. It is precipitated from solution and commonly occurs as a pseudomorphous replacement of pyrite and other iron minerals. As shown in the equations stated on page 65, pyrite is converted in the vadose zone to ferrous sulphate. Since oxygen is present in excess, the ferrous salt is converted to ferric sulphate, which in turn hydrolyzes to ferric hydrate.

$$
\begin{aligned}
& 6 \mathrm{FeSO}_{4}+3 \mathrm{O}+3 \mathrm{H}_{2} \mathrm{O}=2 \mathrm{Fe}_{2}\left(\mathrm{SO}_{4}\right)_{3}+2 \mathrm{Fe}(\mathrm{OH})_{3} . \\
& 4 \mathrm{Fe}(\mathrm{OH})_{3}=2 \mathrm{Fe}_{2} \mathrm{O}_{3} \cdot 3 \mathrm{H}_{2} \mathrm{O}+3 \mathrm{H}_{2} \mathrm{O}
\end{aligned}
$$

These reactions indicate merely certain steps in the processes. An intermediate step may involve the precipitation of basic ferric sulphate.

\begin{tabular}{|c|c|}
\hline & $\begin{array}{l}\text { Ratio of } \\
\mathrm{Fe}_{2} \mathrm{O}_{3} \text { to } \mathrm{H}_{2} \mathrm{O} \text {. }\end{array}$ \\
\hline Turgite.....................2 $\mathrm{Fe}_{2} \mathrm{O}_{3} \cdot \mathrm{H}_{2} \mathrm{O}$. & $\ldots 2$ to $\mathrm{il}$ \\
\hline Goethite................... $\mathrm{Fe}_{2} \mathrm{O}_{3} \cdot \mathrm{H}_{2} \mathrm{O}$. & 2 to 2 \\
\hline Limonite..................2 $\mathrm{Fe}_{2} \mathrm{O}_{3} \cdot 3 \mathrm{H}_{2} \mathrm{O}$ & 2 to 3 \\
\hline Xanthosiderite.............. & 2 to 4 \\
\hline Limnite.................... $\mathrm{Fe}_{2} \mathrm{O}_{3} \cdot 3 \mathrm{H}_{2} \mathrm{O}$ & 2 to 6 \\
\hline
\end{tabular}

The several hydrated iron oxides are:

Ferric hydrate, $\mathrm{Fe}(\mathrm{OH})_{3}$, corresponds to limnite, but through processes of drying or with scant supplies of water the oxides which $72293^{\circ}-$ Bull. $529-13-10$ 
are less highly hydrated will form. Thus limonite forms from limnite and turgite forms when limonite is dehydrated. Turgite, which contains some combined water, but less than limonite, is probably more common in gossans than is generally supposed. The hydrated iron oxides are probably not deposited by ascending hot waters except near the orifices of hot springs.

Hematite is a constituent of igneous rocks, of pegmatites, of contact-metamorphic deposits, and of veins of the deep zone. It is rarely formed by hot ascending waters at shallow or even at moderate depths. The specular anhydrous variety (specularite) is not a common secondary mineral, yet it may be formed under the conditions that prevail in dry, hot countries. Ransome ${ }^{1}$ has described minute crystals of secondary hematite in outcrops at Goldfield, Nev. At the Modoc mine, Morenci, Ariz., ${ }^{2}$ it is formed by the surface oxidation of magnetite and garnet. In tropical countries some residual iron ores and gossans carry abundant hematite. Although hematite is the principal oxide in deposits like those of the Lake Superior iron ranges, which have been formed by the weathering of iron oxides, carbonates, and silicates, ${ }^{8}$ it is noteworthy that limonite greatly predominates in the gossans of most sulphide ores, at least in those that have formed in a temperate climate.

Magnetite, $\mathrm{Fe}_{3} \mathrm{O}_{4}$, is a common constituent of igneous rocks and of magmatic segregations. ${ }^{4}$ It is present in some pegmatites, in most contact-metamorphic deposits, in vein deposits of the deeper zones, and in some ore bodies that are transitional in character between the deposits of the deep zone and those formed at moderate depth. It very rarely fills fissures in ore bodies formed at moderate depth, but at some places it occurs in greatly altered wall rock near such filled fissures. Where the alteration is less intense, usually at some distance from the ore, small dots of magnetite are said to form as a result of alteration of the ferromagnesian minerals by the spent ascending ore-depositing thermal solutions. Where it is primary, magnetite may be a residual mineral in the oxidized zone of any deposit. Minute dark magnetite particles, few if any of them showing crystal form, are found also in the outcrops of many deposits formed at moderate depth, in which the primary ore appears to be free from magnetite. Their minute size and possibly their lack of crystal form will usually serve to distinguish these particles from particles of primary magnetite.

\footnotetext{
1 Ransome, F. L., The geology and ore deposits of Goldfield, Nev.: Prof. Paper U. S. Geol. Survey No. 66,1909 , p. 124.

2 Lindgren, Waldemar, The copper deposits of the Clifton-Morenci district, Arizona: Prof. Paper U.S. Geol. Survey No. 43, 1905, p. 103.

8 Van Hise, C. R., and Leith, C. K., The geology of the Lake Superior region: Mon. U. S. Geol. Survey, vol. 52,1911, p. 188.

t Hastings, J. B., Association of magnetite with sulphides in mineral deposits: Min. and Sci. Press, vol. 97, Sept. 5, 1908, pp. 333, 358.
} 
The extent to which magnetite may form in the outcrop of a sulphide ore body is a matter of considerable importance in connection with the prospecting of gossans, and it has been suggested that it forms in considerable quantities near the surface as a result of certain peculiar climatic conditions. ${ }^{2}$. Many outcrops of magnetite have been regarded as the cappings of sulphide ore bodies and have been. followed downward in the hope of finding sulphide ores of. gold, silver, or copper. At most places it has been found that massive magnetite is of primary origin and is persistent in depth. If rockmaking minerals or the heavy silicates, such as garnet, actinolite, chlorite, and dark mica, are intergrown with the masses of magnetite, it may safely be regarded as a primary deposit and not a product of oxidation.

Melanterite, jarosite, and other sulphates and basic sulphates form abundantly in the oxidized zones of some sulphide ores. The sulphates are highly soluble and are therefore unstable. In some mines they are conspicuously developed, however, on mine timbers and on the faces of ore and wall rock. Weed states that ferrous sulphate is carried by moisture of the air circulating in mine workings. ${ }^{2}$ Jarosite and other basic sulphates are much less soluble than the sulphates and persist in some lodes even at the outcrops. The basic sulphates, as already stated, are probably formed as intermediate products in the hydrolyzation of ferric sulphate to form ferric hydroxide. The abundance of limonite in the gossans indicates that the basic sulphates ultimately lose the sulphate radicle to form hydroxides. By these processes, doubtless, the downward migration of some of the sulphuric acid is delayed and sulphuric acid is contributed to the solutions that percolate through the oxidized ore even after the sulphides have been removed.

Siderite and ankerite. - Siderite is rare as a constituent of contactmetamorphic deposits, but it is found in several veins of the deep zone and also in the gangue or in the altered wall rock of deposits formed at moderate depths by hot ascending water. High temperatures are not necessary for its genesis, however, for it is most abundant in cherty iron carbonate ores of sedimentary origin. In lode ores siderite is in the main primary. Noteworthy examples are the silver-lead veins of the Wood River ${ }^{3}$ and Cour d'Alene districts,

\footnotetext{
1 Graton, L. C., The occurrence of copper in Shasta County, Cal.: Bull. U. S. Geol. Survey No. 430, 1910 , p. 106.

${ }^{2}$ Weed, W. H., Geology and ore deposits of theButte district, Montana : Prof. Paper U.S. Geol. Survey No. 74,1912 , p. 99.

- Lindgren, Waldemar, The gold and silver veins of Silver City, De Lamar, and other mining districts in Idaho: Twentieth Ann. Rept. U. S. Geol: Survey, pt. 3, 1899, p. 190.

- Ransome, F. L., and Calkins, F. C., The geology and ore deposits of the Cœur d'Alene district, Idaho: Prof. Paper U. S. Geol. Survey No. 62, 1908, pp. 95-97.
} 
Idaho. It is found less abundantly also in altered wall rock at Tonopah, Nev., ${ }^{1}$ at Breckenridge, Colo., ${ }^{2}$ and in many other districts.

As a secondary mineral siderite is not abundant. Ferrous carbonate dissolves readily in acids ${ }^{3}$ and it could not form in a highly acid environment. At greater depths, where the environment is alkaline or basic, ferrous carbonate could be precipitated. Siderite is present in fractures in ore of the Highland Boy mine, Bingham, Utah, ${ }^{4}$ and according to Ransome ferrous carbonate is deposited in veinlets crossing the sulphide ore of Breckenridge. ${ }^{5}$ In some of the occurrences ferrous carbonate has been precipitated as ankerite, a salt that also contains, in isomorphous combination, lime carbonate, manganese carbonate, or magnesium carbonate. These salts are somewhat soluble in acid, but none are highly soluble in water.

Pyrite is formed under varying conditions of temperature and from solutions of varied character. It is one of the group termed by Lindgren "persistent" minerals. It is much more abundant, however, in ores associated with igneous processes than in deposits formed by cold solutions or in secondary deposits, although it is not unknown in the latter. Pyrite is contained in some coal beds and is common in sedimentary rocks remote from igneous intrusives. Iron sulphide is not deposited in highly acid waters and is probably not a common or abundant secondary sulphide, but it may be deposited in slightly acid or in neutral solutions. At the surface and above ground water pyrite oxidizes to basic sulphates and to limonite, but it alters in the presence of oxygen more slowly than marcasite or pyrrhotite. In some deposits it persists to the very surface, and, unoxidized, it is found in placer deposits, especially in northern, recently glaciated areas, ${ }^{8}$ though its occurrence in placers is not limited to these areas, for it is found in auriferous gravels in California, ${ }^{7}$ Colorado, and other Western States.

Pyrite as well as marcasite may be obtained by the action of hydrogen sulphide on ferric sulphate solution. Hydrogen sulphide reduces ferric sulphate to ferrous sulphate, with the separation of sulphur, and further action of hydrogen sulphide on ferrous sulphate slowly gives $\mathrm{FeS}_{2}$. The reaction is-

$$
\mathrm{FeSO}_{4}+\mathrm{H}_{2} \mathrm{~S}+\mathrm{S}=\mathrm{FeS}_{2}+\mathrm{H}_{2} \mathrm{SO}_{4} .
$$

\footnotetext{
1 Spurr, J.E., Geology of the Tonopah mining district, Nevada: Prof. Paper U. S. Geol. Survey No. 42, 1005, p. 248.

2 Ransome, F. L., Geology and ore deposits of the Breckenridge district, Colorado: Prof. Paper U.S. Geol. Survey No. 75, 1911, p. 87.

8 Ostwald, Wilhelm, The principles of inorganic chemistry (trans. by Alex. Findlay), London, 1904, p. 580.

4 Boutwell, r. M., Economic geology of the Bingham mining district, Utah: Prof. Paper U. S. Geol. Survey, No. 38, p. 116.

5 Ransome, F. L., op. cit., p. 169.

6 Brooks, A. H., A reconnaissance of the Cape Nome and adjacent gold fields of Seward Peninsula, Alaska, in 1900: Special publication U. S. Geol. Survey, 1901.

' Becker, G. F., Some features of the Rand Banket: Econ. Geology, vol. 4, 1909, p. 379.
} 
This reaction goes on, even at ordinary temperatures, in solutions that contain less than 1 per cent of free sulphuric acid. In solutions of greater acidity and at lower temperatures marcasite will form. ${ }^{1}$ Examples of secondary pyrite are rare, but some have been reported.

According to Spurr, Garrey, and Ball, ${ }^{2}$ pyrite is secondary in the Georgetown region, Colorado, where it has probably been deposited by descending surface waters. Hintze states that pyrite is pseudomorphous after silver glance at Joachimsthal. Veinlets of pyrite cut pyrrhotite copper ore at Ducktown, Tenn., and appear to have been deposited by descending waters. At De Lamar, Idaho, secondary pyrite is associated with kaolin. ${ }^{3}$ In view of the widespread distribution of iron, however, it is remarkable that so few occurrences of secondary pyrite have been reported from the sulphide deposits in the western United States.

Marcasite is rare as a primary mineral of igneous rocks, of pegmatites, of contact-metamorphic deposits, and of veins of the deep zones. It is rarely formed at moderate depths by hot ascending waters but has been formed near the surface or at the orifices of hot springs: It is abundant in the lead and zinc deposits of the Mississippi Valley, where it appears to have been formed by cold solutions near the surface. As pointed out by Allen, "it is to be regarded as a low-temperature mineral deposited in acid solutions. In some pyritic veins it has formed as a secondary sulphide. It may be formed artificially by treating ferric sulphate with hydrogen sulphide. If the solution contains as much as 1 per cent of free sulphuric acid and the temperature is not above $100^{\circ}$, the product is all marcasite. At higher temperatures or in more feebly acid solutions pyrite will form.

At Ducktown, Tenn., marcasite is found sparingly in cracks associated with manganese dioxide about 200 feet below the chalcocite zone. At Goldfield, Nev., according to Ransome, ${ }^{5}$ marcasite is rather characteristic of soft, crushed ore and of gouge and appears in many places to be of later origin than most of the other sulphides. It is a constituent of most of the high-grade ore and in much of it is as old as gold, goldfieldite, etc. It occurs as concentric, radially fibrous shells in soft, dark, and probably enriched ore streaks. As a rule these shells disintegrate on exposure to the air, with the formation of yellow films, apparently containing a little free sulphur, a brown fibrous efflorescence of iron sulphate. It is also a fairly

\footnotetext{
${ }^{1}$ Allen, E. T., Sulphides of iron and their genesis: Min. and Sci. Press, vol. 103, 1911, p. 414.

s Spurr, J. E., Garrey, G. H., and Ball, S. H., Economic geology of the Georgetown quadrangle, Colorado: Prof. Paper U. S. Geol. Survey No. 63, 1908, p. 144.

${ }^{3}$ Lindgren, Waldemar, The gold and silver veins of Silver City, De Lamar, and other mining districts in Idaho: Twentieth Ann. Rept. U. S. Geol. Survey, pt. 3, 1900, p. 124.

- Allen, E. T., op. cit., p. 413.

r Ransome, F. L., The geology and ore deposits of Goldfeld, Nev.: Prof. Paper U. S. Geol. Survey No. 66, 1909 , p. 115.
} 
abundant constituent of the rich primary ore, associated with gold, pyrite, goldfieldite, alunite, quartz, etc.

Pyrrhotite, so far as is indicated by its geologic relations, is distinctly a high-temperature mineral. This conclusion is supported also by the recent synthetical work done by Allen, Crenshaw, Johnston, and Larsen, ${ }^{1}$ who found that pyrrhotite is formed by the decomposition of pyrite in hydrogen sulphide at high temperatures. Pyrrhotite is a primary constituent of igneous rocks ${ }^{2}$ and commonly occurs in magmatic segregations ${ }^{3}$ in pegmatite veins in contact-metamorphic deposits and in veins formed in the deeper zones. A number of its occurrences are mentioned on page 93 . Winslow ${ }^{4}$ mentions the occurrence of pyrrhotite in the disseminated lead ores of southeastern Missouri, but Buckley ${ }^{5}$ does not list it with the ore minerals of this district. As a secondary sulphide in lode ores it is unknown.

Arsenopyrite, FeAsS, is a constituent of many pegmatite veins and has been noted as a contact-metamorphic mineral. It is a primary mineral in deposits of the deep zone and in some lodes formed at moderate depths. In such deposits it commonly carries gold. It is not known as a secondary constituent of ores enriched by descending sulphate solutions.

Chalcopyrite and bornite are discussed on pages 110-111.

\section{SOME GANGUE MINERALS.}

\section{NATURE AND GENESIS.}

Among the minerals found in metalliferous sulphide ores are many that are formed by processes of surface alteration only. These include a large number of the native metals, carbonates, silicates, oxides, and some other compounds. Among the sulphides not one is known to be formed exclusively by secondary processes, although several are secondary in nearly all their known deposits. On the other hand, the primary ores include several sulphides that are almost unknown as secondary minerals. A list of such sulphides should include arsenopyrite, bismuthinite, enargite?, molybdenite, pyrrhotite, and probably others.

The data concerning the genesis of many minerals are inconclusive, and to determine the origin of an ore one must generally rely on paragenesis and mineral association rather than on the occurrence of isolated species. So far as they may serve as an indication of the

1 Allen, E. T., Sulphides of iron and their genesis: Min. and Scl. Press, vol. 103, 1911, p. 414. Allen, E. T., Crenshaw, J. L., and Johnston, John, The mineral sulphides of iron: Am. Jour. Sci., 4th ser., vol. 33, 1912, p. 169.

'Bastin, E. S., A pytrhotitic peridotite from Knox County, Maine: Jour. Geology, vol. 16, 1908, p. 124.

3Coleman, A. P., The Sudbury nickel deposits: Rept. Ontario Bur. Mines, 1904.

-Winslow, Arthur, The disseminated lead ores of southeastern Missouri: Bull. U. S. Geol. Survey No. 132,1896, p. 28.

- Buckley, E. R., Geology of the disseminated lead deposits of Bt. Francols and Washington counties, Mo.: Missourl Bur. Geology and Mines, vol. 8, pt. 1, 1909. 
genesis of the ore, the gangue minerals are perhaps as important as the sulphides.

It is difficult to draw sharp distinctions between gangue and ore minerals and neither of these terms is uniformly used with the same meaning. The gangue minerals are commonly distinguished as the earthy or nonmetallic minerals associated with the metalliferous minerals in the ore. As commonly used the term gangue does not include all minerals without metallic luster nor does it exclude all minerals that contain metals. The iron-bearing silicates are almost universally regarded as gangue minerals in deposits of metals other than iron.

In the table below the minerals listed are regarded as primary. Probably none of these are formed by processes of alteration and superficial enrichment. Most of them are nonmetallic or gangue minerals.

Some minerals which are probably not formed by processes of alteration and superficial enrichment of sulphide ores.

Acmite.

Actinolite.

Adularia.

Albite.

Allanite.

Amphiboles.

Anhydrite.

Augite.

Biotite.

Chromite.

Corundum.

Cryolite.
Diopside.
Emery.
Garnet.
Graphite.
Hornblende.
Humites.
Ilmenite.
Ilvaite.
Lepidolite.
Microcline.
Orthoclase.
Pyroxenes.

\author{
Rbodonite. \\ Rutile. \\ Scapolite. \\ Sillimanite. \\ Spinel. \\ Tourmaline. \\ Tremolite. \\ Vesuvianite. \\ Wollastonite. \\ Zircon. \\ Zoisite.
}

A number of gangue minerals are formed by processes of weathering and hydrometamorphism. Many of them are alteration products or replacements of older gangue minerals, but some are reprecipitated in open fissures. The term hydrometamorphism is used to define those changes which take place through the agency of surface waters at depths somewhat below the oxidizing zones-possibly at horizons where the waters have become neutral or alkaline. Several silicates are developed by such processes, among them chlorite, epidote, muscovite, quartz, serpentine, and talc. Of these minerals all except serpentine and talc are formed also, under some conditions, by ascending thermal waters.

\section{SOME ALUMINUM MINERALS.}

Occurrence.-Aluminum is abundant in the economy of nature and is a constituent of many rock-making minerals. It enters into the composition of several vein-forming minerals. Among these are the 
feldspars, sericite, alunite, kaolin, diaspore, gibbsite, and bauxite. The chemical composition of some of these minerals is shown below:

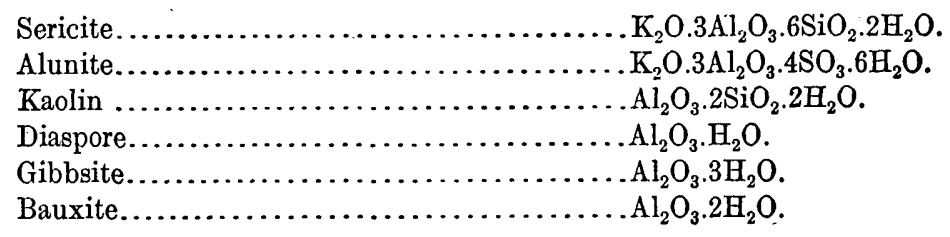

Although new mineral combinations result from hydrothermal processes, there is little evidence that much aluminum is carried into the veins by ascending hot solutions, for aluminum compounds are rare indeed in veins contained in nonaluminous rocks. Cold acid sulphate solutions dissolve aluminum from its compounds very readily, as is indicated by many of the analyses of mine waters (pp. 60-63). There is but little evidence, however, that aluminum compounds are extensively precipitated in open spaces from cold acid waters. Some alunitic veinlets are secondary and some kaolin is deposited in fractures by descending solutions, but in most deposits the larger proportion of the secondary aluminous gangue appears to be a residual product of altered feldspar, sericite, and other minerals. Without much doubt aluminum, like iron, is carried out of sulphide ore bodies in great quantities, for the slimes precipitated from mine waters commonly contain large proportions of hydrous aluminum compounds.

Feldspars.-Of the feldspars, albite and adularia are primary gangue minerals of ore veins. Albite is generally formed at considerable depth; adularia nearer the surface. Neither feldspar is known to form in cold solutions by processes of secondary alteration, although adularia, according to Lindgren, ${ }^{1}$ may be deposited at or near the surface where the temperature could not have been much above $100^{\circ} \mathrm{C}$.

Sericite.-Of the vein minerals that carry aluminum, sericite is perhaps the most common. It is formed in the main as a pseudomorphous replacement of feldspar or other aluminous silicates. In some replacement veins it is very abundant and was probably formed by ascending thermal waters, although there is much evidence that it forms also by processes of hydrometamorphism ${ }^{2}$ that are independent of processes of ore deposition. Hickling ${ }^{3}$ states that sericite is an intermediate product of the kaolinization of potash feldspar exposed to atmospheric weathering. There is little evidence, however, that

\footnotetext{
${ }_{1}$ Lindgren, Waldemar, Metasomatic processes in fissure veins, in Pošepný, Franz, The genesis of ore deposits, 1902, p. 532.

${ }^{2}$ Lindgren, Waldemar, The copper deposits of the Clifton-Morenci district, Arizona: Prof. Paper U. s. Geol. Survey No. 43, 1905, p. 125.

8 Hickling, George, China clay; Its waters and origin: Trans. Inst. Min. Eng. [London], vol. 36, 1908-9, pp. 10, 24.
} 
sericite forms extensively under the conditions that prevail where secondary sulphides are deposited.

Kaolin, $\mathrm{Al}_{2} \mathrm{O}_{3} \cdot 2 \mathrm{SiO}_{2} \cdot 2 \mathrm{H}_{2} \mathrm{O}$, is a common product of rock alteration under surface conditions. It forms where aluminum silicates are leached by ground water that contains either carbonic or sulphuric acid. It is abundantly present in the oxidized zone and in the zone of enrichment in nearly all sulphide ore deposits. As a primary vein constituent ${ }^{1}$ it is exceedingly rare. At Goldfield, Nev., according to Ransome, ${ }^{2}$ it was probably deposited simultaneously with alunite and gold by ascending thermal waters. In several other districts, as at the Rosita Hills, Colo., and Rabbit Hole, Nev., it is associated with alunite and commonly with diaspore or other hydrous aluminum oxides. Rösler ${ }^{3}$ regards kaolin as a pneumatolytic product. According to Gregory, ${ }^{4}$ the deposits of kaolin or china clay of Cornwall and Devon extend to the bottom of some deep mines and probably to greater depths. These he regards as having been formed by solutions containing boric and fluoric acids. Hickling, ${ }^{5}$ however, regards the kaolin of Cornwall as entirely secondary. At Goldfield, Nev., kaolin was formed very near the surface by ascending hot waters and probably by partly oxidized sulphate waters. Nearly all these data appear to show that kaolin is indicative of acid waters.

It has been shown that precipitation of copper sulphide may liberate sulphuric acid, which is available for kaolinization of sericite or feldspar or other aluminum minerals, and consequently kaolin is commonly an associate of secondary chalcocite and covellite in aluminous rocks. At Butte, Mont., according to S. F. Emmons, kaolin associated with secondary copper sulphides was found 1,100 feet deep in the East Gray Rock mine, and Kirk ${ }^{7}$ also has reported it at great depths. It is abundantly developed in the oxidized ores at Bisbee, Ariz., ${ }^{8}$ and probably also with chalcocite ores. It is not uncommon as a secondary product at Morenci, Ariz., ${ }^{9}$ where, according

\footnotetext{
1 Lindgren, Waldemar, The relation of ore deposition to physical conditions: Econ. Geology, vol. 2, 1907, p. 120. Ransome, F. L., Criteria of downward sulphide enrichment: Econ. Geology, vol. 5, 1910 p. 212; discussion by S. F. Emmons, p. 477.

2 Ransome, F. L., The geology and ore deposits of Goldfield, Nev.: Prof. Paper U. S. Geol. Survey No. 66, 1909, p. 192.

3 Rösler, H., Beiträge zur Kenntniss einiger Kaolinlagerstätten: Neues Jahrbuch, Beil.-Ed. 15, 1902, p. 231; Ueber Kaolinbildung: Zeitschr. prakt. Geologie, 1908, p. 251.

4 Gregory, J. W., Criteria of downward sulphide enrichment (discussion): Econ. Geology, vol. 5, 1910, p. 680 .

H Hickling, George, China clay; its waters and origin: Trans. Inst. Min. Eng. [London], vol. 36, 1908-9 p. 24.

6 Emmons, S. F., The secondary enrichment of ore deposits, in Pošepný, Franz, The genesis of ore deposits, 1902, p. 443.

${ }^{7}$ Kirk, C. T., Conditions of mineralization in the copper veins at Butte, Mont.: Econ. Geclogy. vol. 7 , 1912, p. 35.

8 Ransome, F. L., The geology and ore deposits of Bisbee, Ariz.: Prof. Paper U. S. Geol, Survey No. 21 pp. $32,147$.

- Lindgren, Waldemar, The copper deposits of the Clifton-Morenci district, Arizona: Prof. Paper U. S. Geol. Survey No. 43, 1905, p. 111.
} 
to Lindgren, it is not formed during the sericitization of the porphyry which accompanied the formation of the pyritic veins, but it accompanies in small amounts the chalcocite in the veins in porphyry and the copper carbonates in decomposed deposits in limestone. It occurs as veinlets in the quartz of several mines and as large masses in the Longfellow mine, where it is adjoined by limonite. Pure white kaolin commonly occurs also with azurite. According to Lindgren, ${ }^{1}$ its formation in limestone may be explained by the action of aluminum sulphate on free silica in the presence of cupric sulphate:

$$
\begin{aligned}
& \mathrm{Al}_{2}\left(\mathrm{SO}_{4}\right)_{3}+3 \mathrm{CuSO}_{4}+3 \mathrm{CaCO}_{3}+2 \mathrm{SiO}_{2}+6 \mathrm{H}_{2} \mathrm{O}= \\
& \quad 3 \mathrm{CuO} .2 \mathrm{CO}_{2} \cdot \mathrm{H}_{2} \mathrm{O}+\mathrm{H}_{4} \mathrm{Al}_{2} \mathrm{Si}_{2} \mathrm{O}_{3}+3 \mathrm{CaSO}_{4}+3 \mathrm{H}_{2} \mathrm{SO}_{4}+\mathrm{CO}_{2} .
\end{aligned}
$$

At Georgetown, Colo., according to Spurr, Garrey, and Ball, kaolin is crystallized in vugs.

Kaolinic ores commonly carry high values in gold and silver. A noteworthy example is seen at the Montgomery Shoshone mine of the Bullfrog district, Nevada, where the richer ores were found in altered claylike rhyolite. At many places rich kaolinic secondary ores of silver are extensively developed-for example, in the Broken Hill lode, Australia. ${ }^{2}$

Alunite, $\mathrm{K}_{2} \mathrm{O} \cdot 3 \mathrm{Al}_{2} \mathrm{O}_{3} \cdot 4 \mathrm{SO}_{3} \cdot 6 \mathrm{H}_{2} \mathrm{O}$, is a white or faintly pink mineral which in some of its occurrences closely resembles kaolin and sericite. It is formed from either hot or cold solutions. It is not known to have formed under high temperature and great pressure. The alunitic deposits of Goldfield, Rabbit Hole, and Alunite, Nev., and of the Rosita Hills and Rico, Colo., have been formed presumably by hot ascending waters mixed with oxygenated surface waters. The alunitic veinlets at Cripple Creek, Colo., ${ }^{3}$ and at Clifton-Morenci, Ariz.," and the "Chinese talc" of Leadville, Colo., have probably been deposited by descending cold sulphate waters. Alunite is commonly associated with kaolin and the ranges of the two minerals are probably closely similar. Alunite is much less soluble than some other sulphates of aluminum and is therefore relatively stable in oxygenated solutions. The occurrence and genesis of alunite have recently been discussed by Butler and Gale. ${ }^{5}$

Gibbsite, bauxite, and diaspore.-Gibbsite, $\mathrm{Al}_{2} \mathrm{O}_{3} \cdot 3 \mathrm{H}_{2} \mathrm{O}$, bauxite, $\mathrm{Al}_{2} \mathrm{O}_{3} \cdot 2 \mathrm{H}_{2} \mathrm{O}$, and diaspore, $\mathrm{Al}_{2} \mathrm{O}_{3} \cdot \mathrm{H}_{2} \mathrm{O}$, are hydrated aluminum oxides corresponding to the hydrous iron oxide series. By extreme weathering, especially in moist, hot climates, these minerals are formed

1 Lindgren, Waldemar, The copper deposits of the Clifton-Morenci district, Arizona: Prof. Paper U. S. Geol. Survey No. 43,1905 , p. 193.

2 Clark, Donald, Australian mining and metallurgy, 1904, p. 347.

${ }^{8}$ Lindgren, Waldemar, and Ransome, F. L., Geology and gold deposits of the Cripple Creek district, Colorado: Prof. Paper U. S. Geol. Survey No. 54, 1906, p. 125.

- Lindgren, Waldemar, op. cit., p. 119.

5 Butler, B. S., and Gale, H. S., Alunite, a newly discovered deposit near Marysvale, Utah: Bull. U. S. Geol. Survey No. 511, 1912. 
from aluminum silicates. ${ }^{1}$ They have been reported from comparatively few ore veins and those in which they have been identified are almost without exception of late Tertiary age. It is believed that they have been formed in some deposits very near the surface by reactions upon aluminum silicates. ${ }^{2}$ The waters were oxidized solutions, probably hot sulphate waters. In the altered rhyolite of the Rosita Hills, Colo., ${ }^{3}$ diaspore is associated with alunite, quartz, and kaolin, and in altered latite near Silverton, Colo.," with alunite and kaolin. Microscopic crystals of diaspore have been identified at several places in the alunitic-kaolinic veins of Goldfield, Nev. ${ }^{5}$

\section{SILICA.}

It is generally assumed that ascending hot waters are alkaline solutions. If they were acid at their sources they would become alkaline by reactions with wall rocks composed mainly of alkaline silicates. ${ }^{\circ}$ Although the alkalies are generally regarded as its natural solvents, silica is dissolved also by acid waters. The amount, though small, is appreciable even in solutions that give strongly acid reactions, and each of the 37 samples of water whose analyses are stated on pages 60-63 carries silica. In dilute acid waters the silica is generally assumed to be mainly or altogether in the colloidal state. It would be supposed that silica would increase with carbon dioxide, but this is not clearly apparent from a survey of the analyses, nor is the increase of alkalies with silica pronounced. The water that is richest in silica is a strongly acid water of the Comstock lode (No. 23).

The secondary metallic silicates chrysocolla, calamine, and willemite have already been discussed. These are formed possibly in the presence of acid solutions, and to judge from their mineral association, the various forms of hydrated silica, such as chalcedony and chert, may be formed under similar conditions. It is doubtful whether clear crystalline quartz is deposited to any considerable extent by cold descending acid sulphate waters. In the zinc deposits of southwest Wisconsin, which were formed presumably by cold sulphate waters, quartz is notably absent. Some of the disseminated lead ores of southeastern Missouri carry 5 per cent silica, and an appreciable amount of silica is present in the sulphate-

1 Worth, H. and F. J., Geol. Mag., 1903, p. 154. Worth, H., Min. Mag., vol. 13, p. 172, 1902.

2 Hayes, C. W., Geology of the bauxite region of Georgia and Alabama: Sixteenth Ann. Rept. U. S. Geol. Survey, pt. 3, 1895, p. 547; Trans. Am. Inst. Min. Eng., vol. 24, 1894, p. 243.

${ }^{8}$ Cross, Whitman, Geology of Silver Cliff and the Rosita Hills, Colo.: Seventeenth Ann. Rept. U. S. Geol. Survey, pt. 2, 1896, pp. 316-317.

"4 Ransome, F. L., Economic gealogy of the Silverton quadrangle, Colo.: Bull. U. S. Geol. Survey No. 182, 1901 (reprinted in 1903), pp. 121-124.

5 Ransome, F. L., Geology and ore deposits of Goldfield, Nev.: Prof. Paper U. S. Geol. Survey No. 66, 2909, p. 125.

- Allen, E. T., Sulphides of Iron and their genesis: Min. and Sci. Press, vol. 103, 1911, p. 413. 
carbonate waters of the mines of that region. The mine waters ${ }^{1}$ carry considerable quantities of alkalies and alkali earths and give an alkaline reaction. Certain quartzose ore deposits have been regarded as the results of enrichment or concentration by downward-moving waters, and clear crystalline quartz is found in geodes remote from igneous intrusives and forms the interstitial filling of sandstones that have been converted into quartzites.

The association of sulphide ores with abundant quartz is commonly supposed to indicate that they were deposited by alkaline solutions. A study of the paragenesis of most deposits yields results that are in harmony with this conclusion, for quartz, as above stated, is deposited sparingly with secondary sulphide ores. In some deposits, however, it occurs as veinlets filling small cavities and is clearly more recent than the bulk of the ore. Some such veinlets may be due to deposition from descending solutions. At Tintic, Utah, evidence of deposition of quartz in late stages of ore formation is very clear. ${ }^{2}$ At Lake City, Colo., according to Irving and Bancroft ${ }^{3}$ -

the white quartz nccurs without question in more than one generation, but the bulk of it is younger than any of the metallic minerals, for it cuts through sphalerite, galena, tetrahedrite, pyrite, and even rhodochrosite in places. Veinlets of this white quartz also frequently cement shattered masses of the metallic minerals.

At Cripple Creek ${ }^{4}$ quartz replaces celestite, but the period of its genesis is presumably uncertain. As emphasized by Van Hise, ${ }^{5}$ the quartz deposited by descending waters is laid down mainly below the zone of weathering in the "belt of cementation." Lindgren places it in the group with epidote, muscovite, pyrite, and other minerals that are formed distinctly below the zone of active oxidation. The valuable contribution of Wright and Larsen ${ }^{6}$ on the use of quartz as a geologic thermometer should be mentioned here, since it suggests methods that may lead to a more definite understanding of the genesis of quartzose deposits.

Chalcedony, chert, jasper, and like minerals are cryptocrystalline forms of silica which are deposited under different conditions of temperature and pressure. They are more abundant in deposits formed by sedimentary processes, in cold-water deposits, in secondary zones, in sinters, and in veins of late geologic age than in veins formed at depths under higher temperature and pressure. In the latter crystalline quartz is more common.

\footnotetext{
1 Buckley, E. R., Geology of the disseminated lead deposits of St. Francois and Washington counties, Mo.: Missouri Bur. Geology and Mines, vol. 9, pt. 1, 1909, p. 249.

3 Tower, G. W., and Smith, G. O., Geology and mining industry of the Tintic district, Utah: Nineteenth Ann. Rept. U. S. Geol. Survey, pt. 3, 1899, p. 692.

8 Irving, J. D., and Bancroft, Howland, Geology and ore deposits near Lake City, Colo.: Bull. U. S. Geol. Survey No. 478, 1911, p. 60.

- Lindgren, Waldemar, and Ransome, F. L., Geology and gold deposits of the Cripple Creek district, Colorado: Prof. Paper U. S. Geol. Survey No. 54, 1906, p. 123.

5 Van Hise, C. R., A treatise on metamorphism: Mon. U. S. Geol. Survey, vol. 47, 1904, pp. 634-636.

- Wright, F. E., and Larsen, E. S., Quartz as a geologic thermometer: Am. Jour. Sci., 4th ser., vol. 28, 1909 , p. 421.
} 
The secondary chalcedonic quartz that is commonly associated with sulphide ores should be especially noted here. At Cananea, Sonora; Morenci, Ariz.; Goldfield, Nev.; and near Silverton, Colo. (Yankee Girl and similar deposits), many of the ore deposits are capped with highly siliceous outcrops, whereas the ore at short distances below the surface is not so siliceous. A concentration of silica at the surface in some of these deposits is unmistakable, yet in several of them not all the silica appears to be residual quartz of the ore accumulated at the surface by the removal of other minerals. Some shallow pits at Cananea pass through a siliceous capping into white material, streaked with iron oxide, consisting principally of sericite and kaolin with small crystals of pyrite and chalcopyrite and probably of some residual feldspar. This loose cellular material contains very little silica, and as its pore spaces carry crystals of iron and copper sulphates it is a natural inference that sulphate solutions have attacked the kaolin and by long-continued action have removed aluminum and set silica free. Analyses of mine waters indicate that some acid solutions dissolve aluminum in considerable quantities, for it is present in appreciable amount in nearly all the waters and was noted in four samples from Cananea.

Kaolin is generally regarded as a comparatively stable mineral in the oxidized zone. At Morenci, Ariz., however, according to Lindgren, ${ }^{1}$ kaolin is decomposed by acids, which carry aluminum into solution. Such reactions may be attended by the liberation of silica, which presumably would be hydrous silica, but at the very surface, perhaps, the hydrous varieties are dehydrated to form quartz, after the manner that limonite is dehydrated in hot dry climates to form hematite.

Siliceous cappings are extensively developed in and near the copperbearing porphyry at Ely, Nev. Lawson ${ }^{2}$ has shown, however, that some of the siliceous material or "blout" that outcrops at Ely is probably residual jasper.

\section{SULPHUR AND SULPHATES.}

\section{SOLUBILITY.}

The genesis of the principal sulphates of copper, lead, zinc, iron, and aluminum has already been considered. In all their occurrences these minerals are probably secondary, except alunite, the sulphate of aluminum and potash, which is primary in some deposits. Several of the sulphates-for example, those of magnesium, manganese, zinc, and silver-are so soluble that they rarely accumulate in ore

1 Lindgren, Waldemar, The copper deposits of the Clifton-Morenci district, Arizona: Prof. Paper U. S. Geol. Survey No. 43, 1905, p. 193.

Lawson, A. C., The copper deposits of the Robinson mining district, Nevada: Bull. Dept. Geology Univ. California, vol. 4, 1906, p. 327. 
deposits and are of little or no importance as vein minerals. The solubilities of some of the sulphates (determined by Kohlrausch) are stated below.

\begin{tabular}{|r|r|r|r|r|r|r|r|r|}
\hline $\mathrm{K}_{2} \mathrm{SO}_{4}$ & $\mathrm{Na}_{2} \mathrm{SO}_{4}$ & $\mathrm{Ag}_{2} \mathrm{SO}_{4}$ & $\mathrm{BaSO}_{4}$ & $\mathrm{SrSO}_{4}$ & $\mathrm{CaSO}_{4}$ & $\mathrm{MgSO}_{4}$ & $\mathrm{ZnSO}_{4}$ & $\mathrm{PbSO}_{4}$ \\
\hline $\begin{array}{r}111.1 \\
.62\end{array}$ & $\begin{array}{r}168.3 \\
1.15\end{array}$ & $\begin{array}{r}\mathbf{5 . 5} .02 \\
.02\end{array}$ & $\begin{array}{r}0.0023 \\
.00001\end{array}$ & $\begin{array}{r}\mathbf{0} .11 \\
.0006\end{array}$ & $\begin{array}{r}2.0 \\
.015\end{array}$ & $\begin{array}{r}354.3 \\
2.8\end{array}$ & $\begin{array}{r}531.2 \\
3.1\end{array}$ & $\begin{array}{r}0.041 \\
.00013\end{array}$ \\
\hline
\end{tabular}

The upper number shows the number of grams in a solution of 1 liter of water; the lower number the molar solubility.

Of the sulphates that occur as gangue minerals, gypsum, barite, and celestite are important. Anhydrite ${ }^{1}$ is much less common, although it is abundant as a gangue mineral in some deposits of the Newhouse district, Utah. Under oxidizing conditions it is unstable and passes into the hydrated calcium sulphate, gypsum.

\section{OCCURRENCE.}

Native sulphur is not an abundant alteration product of sulphide ores. The sulphur of commerce is obtained from other sources. Small quantities of sulphur, however, are not rare in oxidized or partly oxidized ores. As shown by Vogt, it is formed from several sulphides by reaction with ferric chloride. According to Spurr, sulphur has formed on the outside of sulphide ore on the dump of the Leadville mine at Aspen. ${ }^{2}$ It incrusts sulphide ores in the Bunker Hill mine at Henderson, Mont., and occurs sparingly in the altered ores of Ducktown, Tenn. It is an alteration product of galena in the Mountain View lead mine of Carroll County, Md., ${ }^{3}$ and in the Wheatley mine near Phœnixville, $\mathrm{Pa}{ }^{4}$ With anglesite it coats cavities in galena at Tintic, Utah. ${ }^{5}$

According to Stokes, ${ }^{6}$ sulphur is formed in the first stage of the oxidation of pyrite. The reaction is-

$$
\mathrm{FeS}_{2}+\mathrm{Fe}_{2}\left(\mathrm{SO}_{4}\right)_{3}=3 \mathrm{FeSO}_{4}+2 \mathrm{~S} \text {. }
$$

The sulphur readily reacts with ferric sulphate to give more ferrous sulphate and acid:

$$
2 \mathrm{~S}+6 \mathrm{Fe}_{2}\left(\mathrm{SO}_{4}\right)_{3}+8 \mathrm{H}_{2} \mathrm{O}=12 \mathrm{FeSO}_{4}+8 \mathrm{H}_{2} \mathrm{SO}_{4} .
$$

In the presence of ferrous sulphate and hydrogen sulphide, sulphur unites with ferrous sulphide ${ }^{7}$ to form pyrite and with silver ${ }^{8}$ to form

1 Lindgren, Waldemar, Anhydrite as a gangue mineral: Econ. Geology, vol. 5, 1910, p. 525 .

2 Spurr, J. E., Geology of the Aspen mining district, Colorado: Mon. U. S. Geol. Survey, vol. 31, 1898, p. 239.

8 Williams, G. H., Zeitschr. Krystallographie und Mineralogie, vol, 22, 1894, p. 575.

1 Hintze, Carl, Handbuch der Mineralogie, vol. 1, 1897, p. 90.

- Tower, G. W., jr., and Smith, G. O., Geology and mining industry of the Tintic district, Utah: Nineteenth Ann. Rept. U. S. Geol. Survey, pt. 3, 1899, p. 704.

6 Stokes, H. N., On pyrite and marcasite: Bull. U. S. Geol. Survey No. 186, 1901, p. 15.

${ }^{7}$ Allen, E. T., Crenshaw, J. L., and Johnston, John, The mineral sulphides of iron: Am. Jour. Sci., 4th ser., vol. 33, 1912, p. 169.

Cooke, H. C., unpublished manuscript. 
argentite. By these and other processes it is probably removed from most deposits nearly as rapidly as it is formed.

Gypsum, $\mathrm{CaSO}_{4} \cdot 2 \mathrm{H}_{2} \mathrm{O}$, is a common mineral of ore veins but is rare in portions of deposits that have not been exposed to oxidizing solutions. According to A. E. H. Tutton, ${ }^{1}$ gypsum is decomposed at $150^{\circ} \mathrm{C}$., and possibly at $120^{\circ}$. It has probably been formed invariably at low temperatures. Gypsum is present in decomposed vein matter at Cripple Creek ${ }^{2}$ and at Creede, Colo., and in the secondary sulphide zone at Butte; Mont. ${ }^{3}$ Veinlets of gypsum are abundant at Ely, Nev., in ores in porphyry. At Morenci, Ariz., according to Lindgren, ${ }^{4}$ it is present in oxidized deposits in limestone, where copper carbonates are formed by reaction between sulphates and calcium carbonates. It forms from calcite at Aspen, Colo., ${ }^{5}$ and is in part postglacial, for it cements glacial débris. It is associated with the altered ores. at Tonopah, Nev., ${ }^{6}$ and is present in most of the deposits of Goldfield, Nev., ${ }^{7}$ where it occurs below the zone of oxidation. In the Dixon mine, Bingham, Utah, according to Boutwell, ${ }^{8}$ a considerable body of gypsum was found between the carbonate lead-silver ore and the parent sulphides. Crystals of gypsum are coated with hematite in the Ajax mine at Tintic, Utah. ${ }^{9}$

Barite, $\mathrm{BaSO}_{4}$, has not been identified in igneous rocks, ${ }^{10}$ in pegmatites, or in contact-metamorphic deposits but is found in both the oxidized and unoxidized portions of ore lodes. It is not unknown in some deposits presumably formed at considerable depths. In the Gold Hunter mine of the Cœur d'Alene district " ${ }^{11}$ it is associated with galena, sphalerite, and tetrahedrite. In this district it is present also in the ore of the Standard-Mammoth mine. In some of the sulphide copper ores of Shasta County, Cal. ${ }^{12}$ barite is a characteristic gangue mineral. In many deposits of later age, which were presumably formed nearer the surface, barite is abundant. It is present in many

1 Tutton, A. E. H., The optical constants of gypsum at different temperatures: Proc. Royal Soc. Iondon, vol. $81 \mathrm{~A}, 1908$, p. 40.

2 Lindgren, Waldemar, and Ransome, F. L., Geology and ore depcsits of the Cripple Creek district, Colorado: Prof. Paper U. S. Geol. Survey No. 54, 1906, p. 125.

${ }^{3}$ Winchell, A. N., Criteria of downward sulphide enrichment (discussion): Econ. Geology, vol. 5, 1910, p. 489 .

- Lindgren, Waldemar, The copper deposits of the Clifton-Morenci district, Arizona: Prof. Paper U.S. Geol. Survey No. 43, 1905, p. 120.

${ }^{5}$ Spurr, J. E., Geology of the Aspen mining district, Colorado: Mon. U. S. Geol. Survey, vol. 31, 1898, p. 24.

${ }^{6}$ Spurr, J.E., Geology of the Tonopah mining district, Nevada: Prof. Paper U. S. Geol. Survey No. 42, 1905, p. 96.

TRansome, F. L., The geology and ore deposits of Goldfield, Nev.: Prof. Paper U. S. Geol. Survey No. 66, 1909, p. 128.

8 Boutwell, J. M., Economic geology of the Bingham mining district, Utah: Prof. Paper U. S. Geol. Survey No. 38, 1905, pp. 119, 204.

'Tower, G. W., jr., and Smith, G. O., Geology and mining industry of the Tintic district, Utah: Nineteenth Ann. Rept. U. S. Geol. Survey, pt. 3, 1899, p. 694.

${ }_{10}$ Clarke, F. W., The data of geochemistry, 2d ed.: Bull. U. S. Geol. Survey No. 491, 1911, p. 555.

"Ransome, F. L., and Calkins, F. C., The geology and ore deposits of the Cœur d'Alene district, Idaho: Prof. Paper U. S. Geol. Survey No. 62, 1908, p. 103.

13 Graton, L. C., The occurrence of copper in Shasta County, Cal.: Bull. U. S. Geol. Survey No. 430, 1910. p. 102. 
lode deposits of southwestern Colorado, in some of which, as noted by Irving and Bancroft, ${ }^{1}$ it was formed by ascending hot waters. In some veins that are of great vertical extent barite is abundant in their higher portions but lacking at greater depths. It is inferred that the barite is primary but was deposited under lower pressures than those which prevailed in the deeper parts of the veins. In many Lake City deposits it is the most abundant mineral. It is clearly of earlier deposition than quartz, for quartz very commonly incrusts crystals that project into central cavities.

The deposits at Creede, Colo., ${ }^{2}$ contain considerable barite. Some of this is thought to have formed as a primary constituent of the ore, but some that fills cracks and crevices in limonite is later than the first period of mineralization and is probably secondary. At Wagonwheel Gap, near by, it has formed along a fissure near which hot ${ }^{\circ}$ springs now issue. At Aspen, Colo., barite is cut by veinlets of argentite and native silver and is intimately associated with polybasite. ${ }^{3}$ It is found with kaolinite in deposits at Goldfield, Nev. ${ }^{4}$ Barite is commonly present in the gangue of copper deposits in the "Red Beds" of the Southwest that have formed through the agency of cold solutions.

Although barite forms under conditions of surface alteration, it is not so commonly associated with the secondary sulphides as gypsum and kaolin. Owing to its insolubility it persists in the oxidized zones. In many deposits it outcrops at the surface and it is found in oxidized ores from which all the sulphides have been dissolved.

Celestite, $\mathrm{SrSO}_{4}$, is not reported as an original constituent of igneous rocks, of pegmatites, or of contact-metamorphic deposits. It occurs in certain ore bodies that were formed relatively near the surface by hot ascending waters. It is formed also in deposits far removed from igneous rocks, and in some lodes it is probably a secondary mineral deposited by cold sulphate waters. It is not nearly so common as barite.

Although celestite is relatively rare in ore veins, at Cripple Creek it is both a primary and secondary mineral. Slender needles of celestite coat openings in the vein fissures far below the zones of oxidation ${ }^{\theta}$ and pseudomorphs of quartz after celestite are of frequent occurrence in some of the Cripple Creek deposits.

\footnotetext{
1 Irving, J. D., and Bancroft, Howland, Geology and ore deposits near Lake City, Colo.: Bull. U. S. Geol. Survey No. 478, 1911, pp. 34, 35, 45.

8 Emmons, W. H., and Larsen, E. S., Geology and ore deposits of Creede, Colo.: Bull. U. S. Geol. Survey (in preparation).

${ }^{3}$ Spurr, J. E., Geology of the Aspen mining district, Colorado: Mon. U. S. Geol. Survey, vol. 31, 1898, p. 228.

4 Ransome, F. L., The geology and ore deposits of Goldfleld, Nev.: Prof. Paper U. S. Geol. Survey No. 66, 1909, p. 128.

${ }^{5}$ Lindgren, Waldemar, Graton, L. C. and Gordon, C. H., The ore deposits of New Mexico: Prof. Paper U. S. Geol. Survey No. 68, 1910, p, 78.

- Lindgren, Waldemar, and Ransome, F. L., Geology and gold deposits of the Cripple Creek district, Colorado: Prof. Paper U. S. Geol. Survey No. 54, 1806, p. 125.
} 
Jarosite, $\mathrm{K}_{2} \mathrm{O} .3 \mathrm{Fe}_{2} \mathrm{O}_{3} \cdot 4 \mathrm{SO}_{4} \cdot 6 \mathrm{H}_{2} \mathrm{O}$, is a brownish-yellow sulphate that resembles limonite in color and occurrence and is easily confused with that mineral. Like limonite it forms in the oxidized zone of iron sulphide deposits. It occurs at Tintic, Utah, and probably at Goldfield, Nev. ${ }^{1}$ It is found at the outcrop of the Amethyst vein at Creede, Colo. Mr. B. S. Butler informs me that it is present in the oxidized ore in a number of deposits in Utah.

\section{OARBONATES.}

The alkali-earth carbonates are fairly insoluble in water, as indicated in the following table:

Solubility of some carbonates in water at $18^{\circ}$.

\begin{tabular}{|c|c|c|c|c|c|c|c|c|}
\hline $\mathrm{K}_{2} \mathrm{CO}_{3 .}$ & $\mathrm{Na}_{8} \mathrm{CO}_{8 .}$ & $\mathrm{Ag}_{2} \mathrm{CO}_{3}$. & $\mathrm{BaCO}_{8 .}$ & $\mathrm{SrCO}_{8 .}$ & $\mathrm{CaCO}_{3}$ & $\mathrm{MgCO}_{8 .}$ & $\mathrm{ZnCO}_{2}$. & $\mathrm{PbCO}_{8 .}$ \\
\hline $\begin{array}{r}1080 \\
5.9\end{array}$ & $\begin{array}{r}193.9 \\
1.8\end{array}$ & $\begin{array}{c}0.03 \\
.0001\end{array}$ & $\begin{array}{c}0.023 \\
.00011\end{array}$ & $\begin{array}{c}0.011 \\
.00007\end{array}$ & $\begin{array}{c}0.013 \\
.00013\end{array}$ & $\begin{array}{c}1.0 \\
.01\end{array}$ & $\begin{array}{l}0.04 ? \\
.0003 ?\end{array}$ & $\begin{array}{c}0.001 \\
.00003\end{array}$ \\
\hline
\end{tabular}

The upper number gives the grams of anhydrous salt held in solution by 1 liter of water; the lower number the molar solubility or number of mols contained in a liter of the saturated solution. The determinations were made by Kohlrausch by the conductivity method.

In sulphide ores barium carbonate (witherite) and strontium carbonate (strontionite) are rare. Calcite and dolomite are more common as vein minerals. In accordance with their occurrence in deposits formed under widely different conditions both are termed persistent minerals. ${ }^{2}$ Both are attacked by sulphuric acid, and calcite is dissolved in very dilute acid sulphate solutions. It could not be formed, therefore; in moderately acid waters. Where secondary in sulphide deposits, both calcite and dolomite are formed mainly below the zone of active oxidation, in solutions that have become feebly acid or alkaline.

The occurrence of the carbonates of copper, lead, and zinc has already been discussed. These are formed from acid solutions and are deposited extensively in oxidized zones. None of them are known to form in depth by deposition from thermal waters. Siderite (ferrous carbonate) is less common in lode deposits and is generally primary. It is deposited, however, under some conditions of sedimentation-for example, in the "black band" iron ores. Its occurrence as a product of surface alteration is exceedingly rare,

1 Ransome, F. L., The geology and ore deposits of Goldfield, Nev.: Prof. Paper U. S. Geol. Survey No. 66,1909, p. 133.

${ }^{2}$ Lindgren, Waldemar, The relation of ore deposition to physical conditions: Econ. Geology, vol. 2, 1907, p. 108.

$72293^{\circ}-$ Bull. $529-13-11$ 
although the ferrous-carbonate molecule is present in ankerite and in some other carbonates which are assumed to be secondary in some deposits. According to Ransome, ${ }^{1}$ impure siderite occurs in veinlets traversing sulphide ores at Breckenridge, Colo.

Rhodochrosite, the carbonate of manganese, is fairly abundant in many precious-metal ores. In the United States it is almost unknown in such deposits that are older than the Tertiary. There is little evidence that rhodochrosite is deposited by descending sulphate waters, although the manganese-carbonate molecule is probably present in some complex carbonates that are assumed to be secondary. In the bog-manganese deposits, which have formed by sedimentary processes, the manganese oxides predominate, but some of these deposits contain also rhodochrosite. ${ }^{2}$ Although the soluble carbonates precipitate silver carbonate from solutions of silver salts in the laboratory, and although silver sulphate is more soluble than silver carbonate, the latter is nevertheless unknown in mineral deposits.

\section{SUMMARY REVIEW OF SEVERAL CLASSES OF DEPOSITS.}

On the following pages a number of the principal sulphide deposits of copper, gold, and silver ores in North America are briefly described, in order that the several districts may readily be compared to ascertain the extent, character, and distribution of the secondary ores in them. As already stated, many of the problems arising in this connection are now only in process of solution. Yet by grouping these deposits in several ways, certain facts are more or less clearly indicated. The conclusions stated below appear to be warranted by the data presented herewith.

\section{COPPER DEPOSITS IN GENERAL.}

1. The deposits of many copper districts do not exhibit evidence of appreciable chalcocite enrichment. Examples: Kasaan Peninsula, Alaska; Prince William Sound, Alaska; Sudbury, Ontario; Boundary district, British Columbia; Copperopolis, Cal.; Frisco, Utah (Cactus mine); La Reforma mine, Mexico; probably San Jose, Velardeña, and Nacozari, Mexico. The mines of the Braden Copper Co., operating in Chile, may be added to this list.

2. Deposits showing no ohalcocite enrichment, located in countries that have recently been glaciated, include those of the following regions: Kasaan Peninsula and Prince William Sound, Alaska; Sudbury, Ontario; Boundary district, British Columbia. They include also deposits in countries that, so far as I can discover, have not

\footnotetext{
1 Ransome, F. L., Geology and ore deposits of the Breckenridge district, Colorado: Prof. Paper D. S. Geol. Survey No. 75, 1911, p. 169.

Penrose, R. A. F., jr., The superficial alteration of ore deposits: Jour. Geology, vol. 2, 1894, p. 306.
} 
recently been glaciated: La Reforma, Copperopolis ?, Nacozari, San Jose.

3. Deposits that do not contain appreciable chalcocite zones are found in countries of widely different latitudes: Alaska, British Columbia, Ontario, California, Utah, Mexico, and Chile.

4. Deposits that do not contain appreciable chalcocite zones exhibit primary ores containing pyrrhotite: Kasaan Peninsula and Prince William Sound, Alaska; Sudbury, Ontario; Boundary district, British Columbia. They also exhibit primary ores, in the available descriptions of which pyrrhotite is not mentioned: La Reforma; Copperopolis; Cactus mine, Utah; Nacozari (some bornite enrichment), San Jose, Velardeña, Mexico; Braden, Chile.

5. All or nearly all the pyrrhotitic deposits which do not exhibit secondary chalcocite zones are in recently glaciated areas. Some of these deposits carry sphalerite.

6. All the deposits described that are located in the lower latitudes and that show no appreciable chalcocite enrichment have primary ores of pyrite and chalcopyrite. Zinc blende is wanting or not abundant in most of these deposits, but Velardeña (Copper Queen $\min \theta$ ) and Frisco (Cactus mine) are exceptions. Possibly there are some others. In none of these deposits is pyrrhotite reported.

7. In glaciated areas oxidized ores for this group are subordinate or lacking. In areas not glaciated a few of the deposits exhibit oxidized ores of some commercial importance.

8. In all or nearly all the deposits in low latitudes which do not show appreciable chalcocite enrichment complete oxidation has proceeded to comparatively shallow depths. The lodes in general are said to be relatively impervious. The copper-sulphate solutions probably move laterally and issue at the surface before reducing conditions are met, or, escaping into the wall rock, their copper content is scattered. La Reforma is a good example.

9. I know of no pyrrhotitic copper deposit in a low latitude or in a country not glaciated that shows no chalcocitization whatever. Some pyrrhotite at least reacts so readily with acid to give hydrogen sulphide that acid solutions may be reduced and copper sulphide may be precipitated even with access of some air. Precipitation of a copper sulphide is now in progress on ore surfaces in mines of Ducktown, Tenn., above the present water level. Such precipitation probably does not take place in the higher levels on pyrite and chalcopyrite.

10. The copper content of some of the pyrrhotitic deposits in glaciated areas decreases with increase in depth. Possibly a former chalcocite zone was planed off by the ice and a secondary chalcopyrite zone was not completely removed. This is strongly suggested by relations in the Boundary district, British Columbia. 
COPPER DEPOSITS WITH SHALLOW CHALCOCITE ZONES.

11. Many copper deposits exhibit shallow chalcocite zones. These include Ducktown, Tenn.; Stone Hill, Ala.; Gossan lead, Va.; Ely, Vt.; Queen of Bronze mine, Oreg.; Santiago, Cuba; Pinar del Rio, Cuba; and La Dicha, Mexico. Possibly Encampment, Wyo.; Shasta County, Cal.; and the Highland Boy mine of Bingham, Utah, should be mentioned here.

12. The examples cited above are outside of the limits of the continental ice sheets. A deposit on Prince William Sound, Alaska, however, shows a few inches of secondary sulphide ore.

13. The ores of all but one of these deposits carry pyrrhotite. In most of them it is abundant. The ores of Shasta County, Cal., carry considerable sphalerite but little or no pyrrhotite.

14. The chalcocite zones of most of the deposits of this group range in vertical dimensions from 1 foot to 10 feet. In some of the deposits, however, their vertical extent is 200 feet or more.

15. The secondary chalcocite ores of these deposits are generally rich. Some of them carry over 20 per cent copper.

16. Gold or gold and silver are very commonly concentrated in the secondary copper ores.

17. A zone of chalcopyrite enrichment may exist below the chalcocite zone, and it may be of considerably greater vertical extent than the secondary chalcocite zone. Examples: Ducktown, Tenn.; Rio Tinto, Spain; possibly others.

18. Pay ores are commonly found below the zone of probable chalcopyrite enrichment and some of them are of moderately high grade. Few, if any, however, could be classed as bonanza.

\section{COPPER DEPOSITS WITH MODERATELY DEEP CHALCOCITE ZONES.}

19. In many deposits of copper-sulphide ores secondary chalcocite extends to moderately great depths. Examples are Morenci, Bisbee, Globe, Miami, Ray, and Jerome, Ariz.; Santa Rita (Chino), N. Mex.; Ely, Nev.; Bingham, Utah (in part); Cananea, Sonora (in part); Butte, Mont. In many of these deposits the vertical extent of the chalcocite zone is from 200 to 1,000 feet or more.

20. These deposits are outside of the margins of the continental ice sheets.

21. Many of these deposits are in countries now arid.

22. Pyrrhotite is subordinate in the ores of all these deposits.

23. The primary ores of several of these districts carry appreciable sphalerite. Examples are Morenci, Metcalf, Jerome?, Cananea (West Cobre Grande and Kirk). At Morenci and Metcalf the bulk 
of the chalcocite is within 400 feet of the surface. In the West Cobre Grande chalcocite passes into low-grade zincky ores about 200 feet below the surface. Exact data are not available for Jerome and for certain Bingham mines.

24. The deepest secondary chalcocite zones are in ore bodies that contain little or no pyrrhotite or sphalerite. Examples: Bisbee, Globe, and Miami, Ariz.; Bingham laccolith, Utah; Butte, Mont. (in part). A few deposits of this character have chalcocite zones that probably are not of much greater vertical extent than chalcocite zones in some sphalerite deposits. Examples are Ray, Ariz., and possibly Santa Rita (Chino), N. Mex.

25. Sphaleritic ores do not appear to check the downward migration of copper so readily as they check the downward migration of silver. (See below.)

26. Important zones of chalcopyrite enrichment below the chalcocite zones have not been clearly differentiated in any of these deposits.

\section{COPPER DEPOSITS WITH DEEPLY OXIDIZED ZONES.}

27. Copper deposits having deeply oxidized zones include many of those of 'Tintic, Utah, and Bisbee, Ariz.; some of Bingham, Utah; and the Snowstorm mine of the Cour d'Alene district, Idaho.

28. None of these deposits are known to carry pyrrhotite or abundant sphalerite.

29. The data here presented indicate that in general oxidized zones above ores containing abundant pyrrhotite and sphalerite are more thoroughly oxidized than those above ores containing pyrite and chalcopyrite without pyrrhotite or sphalerite, but such oxidation is not likely to extend to depths so great in pyrrhotite or sphalerite ores. The pyrite ores of Rio Tinto, Spain, those of La Reforma mine, Mexico, and some of the deposits at Butte Mont., are capped by thoroughly oxidized material; possibly there are others.

30. The deepest zones of oxidized copper ores are in deposits in limestone. Examples: Tintic, Utah, and Bisbee, Ariz.

31. Although oxidation extends 2,000 feet below the surface at Tintic, and perhaps 1,600 feet or more at Bisbee, it is, in general, not complete at such depths.

32 . Not all the decply oxidized zones of copper ores are in arid countries (Snowstorm mine, for example).

33. The nature and vertical extent of chalcocite enrichment and the depth of oxidation depend upon the permeability of the deposits, the chemical and mineral composition of the ores and wall rock, the present and the past climatic environment, and the geologic history. 


\section{GOLD DEPOSITS EXHIBITING SECONDARY CONOENTRATION.}

34. Many auriferous deposits in the surficial zone appear not to have been enriched by secondary agencies. The distribution of valuable deposits in the lodes of Berners Bay and Douglas Island, Alaska, shows no relation to the present surface. In this glaciated region there is little or no concentration of gold at the surface by removal of valueless material from the outcrops.

35. There is no evidence of solution and reprecipitation of gold in some other auriferous deposits in lower latitudes, although there may be an increase of values at the outcrop through oxidation that is attended by the removal of material with which the gold is associated. Examples are Mother Lode, Nevada City, Grass Valley, Ophir, and similar deposits of California; Homestake deposits of the Black Hills; Cable mine, between Philipsburg and Anaconda, Mont.; and several deposits in the Appalachians. Practically all the important deposits in these regions have supplied placer gold.

36. There are still other deposits whose relations do not indicate a migration of gold and from which no placers have been exploited. Examples: Edgemont, Nev.; Goldfield, Nev.; Silver Peak, Nev.; Cripple Creek, Colo. (subordinate placers). Not all of these are in arid regions, Edgemont and Cripple Creek being moderately well watered.

37. Solution, migration, and reprecipitation are clearly indicated in a number of auriferous deposits. In some of them this is inferred from paragenetic evidence, in others from the great richness of the bonanzas compared with the unaltered ore and from the relations of the bonanzas to the present surface. Examples are found at Creede, Colo. (Amethyst vein); Ouray, Colo. (Camp Bird vein); Telluride, Colo. (Tomboy vein); some veins in quartzite near Leadville, Colo.; Little Burro Mountains, N. Mex. (Wyman vein); Bodie, Cal.; Bullfrog, Nev.; Manhattan, Nev.; Gold Circle, Nev.; Mohave, Cal. (Exposed Treasure vein); Georgetown, Colo. (auriferous lodes?); Marysville, Mont. (Drumlummon veins). All the deposits named above carry manganese in greater or less amounts.

Although they are not reviewed herein, several districts outside of North America may be mentioned as examples of manganiferous deposits with rich superficial zones. One of these is the Aroroy district, Philippine Islands. Here, according to Henry G. Ferguson, there is a difference in the behavior of gold in manganiferous deposits and in those containing little or no manganese dioxide at the outcrop. He says: ${ }^{1}$

As far as a limited observation extends, all veins which on their outcrops show rich ore are those in which manganese oxide is not prominent. Evidence from development work, though very meager, seems to show that the values in these veins do not

${ }^{1}$ Ferguson, H. G., The gold deposits of the Philippine Islands: Econ. Geology, vol. 6, 1911, p. 126. 
increase downward, as is the case with the manganese-bearing veins, and in some at least decrease greatly a few meters from the surface. The manganese-bearing veins, on the other hand, which at their outcrop may be nearly barren, carry values increasing progressively downward. This increasing value in moderate depth is shown in many cases, but most clearly by samples taken in the 30-meter raise to surface from the upper level of the Nancy mine of the Eastern Mining Co. In this case there was an increase downward from the outcrop from less than 1 gram to over 6 grams per ton.

A conspicuous foreign example is the Mount Morgan mine in Queensland, one of the largest gold deposits in the world. The ores in depth are sulphides and carry a considerable percentage of copper but relatively little gold. To a depth of 270 feet the surface ores contained masses of enormously rich gold ore highly stained with manganese. Much of this ore carried several ounces to the ton, but copper was almost entirely absent. As pointed out by Donald Clark, ${ }^{1}$ there is clear evidence of solution and precipitation of gold. It was not all dissolved, however, for some placer gold is found in beds of Cretaceous age near by.

The Hauraki gold fields, New Zealand, may be mentioned also. The vein filling is massive or comby quartz, with some manganese dioxide. According to A. M. Finlayson, ${ }^{2}$ some of the small ore shoots are exceedingly rich. The bonanza zone extends 400 to 600 feet below the surface.

38. Four districts are mentioned below in which gold has migrated in solution in ores that are not stated to carry manganese. Two of these (Haile mine, South Carolina, and Hedley district, British Columbia) are in regions of basic rocks, which possibly supply manganese to the solutions. Two others (Bohemia district, Oregon, and Summit district, Colorado) are in acidic and intermediate rocks. Manganese is not mentioned as a vein constituent, although its presence is not denied.

39. The outcrops of manganiferous gold ores are commonly leached, and placer deposits are not so frequently developed from them as from nonmanganiferous lodes. This is apparent from the inspection of the lists above. Two examples are conspicuous exceptionsMarysville, Mont., and Mount Morgan, West Australia. Both have enormously rich deposits, practically at the surface; both have supplied placer gold. The unaltered ores of one (Marysville) carry calcite, which reduces auriferous solutions very rapidly. Some rich manganiferous gold ores are found very near the surface at Bullfrog and Manhattan, Nev. At both places the gangue is calcitic.

40. It is concluded that the solution of gold depends in the main on the presence, simultaneously, of manganese and chlorides. Its migration depends on the permeability of the lodes and the material

1 Clark, Donald, Australian mining and metallurgy, Melbourne, 1904, p. 267.

2 Finlayson, A. M., Problems in the geology of the Hauraki gold fields, New Zealand: Econ. Geology, vol. 4, 1909, p. 641 . 
of the primary ores. Of the common minerals, calcite and pyrrhotite will probably reduce auriferous solutions most rapidly. Some other carbonates and sphalerite are doubtless somewhat less efficient. The action with pyrite and chalcopyrite is slower still.

\section{SILVER AND SILVER-GOLD DEPOSITS.}

41. Enrichment is clearly indicated in a number of silver and silver-gold deposits. Examples may be found at Georgetown, Breckenridge, Leadville, Aspen, Silverton, Creede, and Lake City, Colo.; at Philipsburg, Butte, and Neihart, Mont.; on the Comstock lode, at Tonopah, and at Pioche, Nev.; at Mohave, Cal.; and in the St. Eugene mine, at Moyie Lake, British Columbia. In several of these districts, but not in all, a migration of gold also is clearly indicated. All the districts of silver-gold deposits in which gold is assumed to have migrated include manganiferous ores.

42. In deposits carrying both metals, especially where chlorides form, secondary silver minerals are likely to be precipitated as bonanzas near the surface, while gold may be carried to greater depths. Examples are deposits of Mohave, Cal. (Exposed Treasure mine), Creede, Colo. (Amethyst lode), and probably the Comstock lode, Nevada, although in the Comstock district silver chloride is not abundant.

43. In manganiferous deposits of gold and silver where chlorides do not form extensively, silver is probably carried downward to greater depths than gold. Clearly defined examples are rare, perhaps because gold is not dissolved in cold mineral waters free from chlorine and because silver chloride is so nearly insoluble that precipitation of cerargyrite is almost certain to take place in the ores where chlorides are supplied by the ground waters, even in small amounts. Although some examples seem to indicate that silver migrates downward below the zone where gold is precipitated, the data are generally inconclusive.

44. Abundant pyrrhotite in the primary ore quickly halts the downward migration of both silver and gold. Some of the secondary ore of the "black copper floors" of Ducktown, Tenn., carried considerable silver. A sample assay by Genth showed over 1 per cent. Not many examples are available, probably because the pyrrhotitic ores carry copper and the rich superficial concentrations were worked out before the days of electrolytic refining. Since acid waters generate hydrogen sulphide on at least some pyrrhotite almost immediately, and since hydrogen sulphide precipitates gold and silver perhaps completely, the gold and silver could not descend to any considerable depth in pyrrhotitic ores. Although the principal ore deposits of Rio Tinto, Spain, carry little or no pyrrhotite and although zinc blende is not abundant in most of them, they should be mentioned here. Above 
one of the principal deposits there is a "floor" of rich silver and gold ore at or just above the top of the chalcocite zone."

45. In general, without much doubt, in copper deposits where silver and gold migrate downward it is. in the upper part of the zone of secondary copper sulphides that the precious metals are precipitated rather than in the lower part.

46. Many deposits of rich silver ore and some deposits of rich silver-gold ore terminate downward in low-grade sphalerite ores. Abundant examples are to be found in the regions of Georgetown, Breckenridge, Creede, and Lake City, Colo.; Pioche, Nev.; and Lake Moyie, British Columbia. In most of these districts the bonanzas of silver ores are comparatively near the surface. In the Comstock lode and at Tonopah, Nev., and in the Granite-Bimetallic vein at Philipsburg, Mont., a little zinc is present, but not much. In these the richer ores are found at greater depths. At Creede, Colo., in the Amethyst vein, secondary silver ore has been formed at greater depths than is usual in the region of Georgetown and Breckenridge, notwithstanding the fairly abundant zinc sulphide in the primary ore at Creede. This, I believe, is to be explained by excessive fracturing of the Amethyst vein, which at some places is little more than an ore breccia, and by the fact that soluble carbonates are almost lacking in the ore.

A conspicuous example outside of America of a deposit of rich silverlead ore passing into low-grade sphalerite ore in depth is the great Broken Hill lode of New South Wales. This deposit is in schists and in general conforms to the schistosity. Judging from the drawings of Capt. Warren ${ }^{2}$ it resembles in certain structural features the broken folds of some of the deposits of Ducktown, Tenn. Though classed as a saddle reef by J. B. Jaquet ${ }^{3}$ on account of its bifurcating structure, it may be considered, for the purpose of this discussion, a tabular mass, since the bifurcation of the lode is shown between the 415 and 515 foot levels, from which point it extends to the surface as a tabular body. Without much doubt a considerable amount of the lode has been eroded, and the valuable metals appear to have concentrated in the remaining portion relatively near the surface. Siliceous limonitic manganitic ore is said to have extended from the surface to about 300 feet below. This ore was 20 to 100 feet wide and, according to Phillips and Louis, ${ }^{4}$ carried 7 to 45 ounces silver and 18 per cent lead. At the bottom of this siliceous ore was a narrow zone of kaolinic ore, portions of which carried great bonanzas of silver, largely in the form of chloride. Below this level, on block 10, at a depth

1 Vogt, J. H. L., Das Huelva-Kiesfeld: Zeitschr. prakt. Geologie, 1899, p. 250. Finlayson, A. M., T'hn pyritic deposits of Huel va, Spain: Econ. Geology, vol. 5, 1910, p. 410.

Reminiscences of Broken Hill, quoted by Clark, Donald, Australiain mining and metallurgy, Mel bourne, 1904. The original is not accessible to me.

8 Jaquet, J. B., Geology of the Broken Hill lode and Barrier Ranges mineral field, New South Wales. Mem. Geol. Survey New South Wales, Geology No. 5, 1894.

- Phillips, J. A., A treatise on ore deposits, 2d ed., by Henry Louis, 1896, p. 656. 
between 400 and 500 feet below the surface, were rich friable sulphides with galena and zinc blende." Below the rich friable sulphides values decreased greatly, the ore being composed of "compact sulphides, or an intimately mixed mass of galena and blende, with a gangue of quartz, rhodonite, and garnet." I have no record that pyrrhotite is present in these ores, though it is mentioned as abundant in the Pinnacles mine, 9 miles southwest of Broken Hill. ${ }^{2}$

47. Auriferous and argentiferous acid solutions are probably more sensitive than cupriferous solutions to the presence of sphalerite, because ferrous sulphate will precipitate gold and silver from chloride and sulphate waters, whereas copper sulphate will remain in solution with ferrous sulphate. Hydrogen sulphide, which may be generated by acid and sphalerite, will precipitate all three of the metals, but hydrogen sulphide is used up to convert ferric to ferrous sulphate. Thus copper may remain in solution as long as any ferric sulphate is present, but gold and silver would go down in mixtures of ferric and ferrous sulphates. Under similar conditions in sphaleritic ore copper would descend to greater depths than gold and silver.

48. Although the chemical and mineralogic environment in depth have been emphasized in the foregoing discussion, it is recognized that permeability of the primary ores is a factor of the greatest importance in determining the depths to which the metals may descend, whatever the character of the primary sulphides.

\section{REVIEW OF MINING DISTRICTS.}

BUTTE, MONTANA.

The Butte district, ${ }^{3}$ in western Montana, is an area of quartz monzonite (the Butte quartz monzonite, frequently called granite) which is intruded by a later aplite, or aplitic granite (in early reports sometimes alluded to as the "Bluebird granite"), and by rhyolite porphyry (in early reports called quartz porphyry).

Dikes of late Tertiary rhyolite cut the granite, and effusive rhyolite (rhyolite dacite) rests upon it. In the western part of the region are Tertiary lake beds more recent than the granitic rocks. These are composed of sand, gravel, and water-laid tuff. The rhyolite porphyry has in some reports been referred to as the "Modoc porphyry," and it is locally known by that name. In the most recent publica-

\footnotetext{
1 Phillips, J. A., A treatise on ore deposits, 2d ed., by Henry Louis, 1896, p. 347.

3 Idem, p. 657.

'Weed, W. H., Emmons, S. F., and Tower, G. W., jr., Butte folio (No. 38), Geol. Atlas U. S., U. S. Geol. Survey, 1897. Weed, W. H., Geology and ore deposits of the Butte district, Montana: Prof. Paper U.S. Geol. Survey No. 74, 1912. Winchell, H. V., Synthesis of chalcocite and its genesis at Butte, Mont.: Eng. and Min. Jour., vol. 75, 1903, pp. 782-784. Sales, Reno, Ore shoots at Butte, Mont.: Econ. Geology, vol. 3, 1908, pp. 326-331; Superficial alteration of the Butte veins: Idem, vol. 5, 1910, pp. 15-21. Simpson, J. F., The relatton of copper to pyrite in the lean copper ores of Butte, Mont.: Econ. Geology, vol. 3, 1908, pp. 628-636. Kirk, C. T., Conditions of mineralization in the copper veins at Butte, Mont.: Econ. Geology, vol. 7, 19i2, pp. 35-82.
} 
tion on this area ${ }^{1}$ it is called rhyolite porphyry. Its groundmass is microcrystalline, however, and, as Weed very truly states, it might be classed as granite porphyry.

The quartz monzonite, aplite, and porphyry, which contain all the ores, are phases of the great Boulder batholith, which extends some 64 miles southward from a point near Helena and is 12 to 16 miles wide. This batholith intrudes Paleozoic and Cretaceous sedimentary rocks and along its borders has induced contact metamorphism by which the typical garnet zones have been developed in the calcareous sediments.

Although the rocks of the batholith are in general of comparatively uniform composition, the Butte quartz monzonite is a somewhat more basic phase. The aplite represents a differentiation product that was forced into cracks in the quartz monzonite after that rock had cooled. Although there is an unusual amount of the aplite in the region about Butte, its economic significance is not clear. Indeed, the lodes, on passing from the quartz monzonite into aplite, are impoverished, and Weed ${ }^{2}$ states that the aplite is uncongenial for ore deposition because it fractures with difficulty and is not readily replaced.

There seems to be a genetic relationship between the copper ores and the rhyolite porphyry, although such a relation is not conclusively proved. The rhyolite porphyry is found only in the eastern portion of the copper area, where it is younger than the Butte quartz monzonite and older than the veins, since even the oldest veins cut through it. The veins in the porphyry, like those in the aplite, are narrower and poorer than those in the quartz monzonite. The porphyry is, however, the youngest igneous rock exposed that is older than the oldest veins.

The copper ores are included in an area about $1 \frac{1}{2}$ miles long and a mile wide, and this area is almost surrounded by a much larger area containing closely spaced silver-bearing veins. Pronounced parallelism is noticeable in veins of both groups.

The region is highly fractured and extensively faulted; indeed, faulting movements have continued probably to the present day. In a general way the fractures, as stated by Weed, may be separated into two classes; the first, formed before the rhyolitic eruptions (Miocene), trend either $(a)$ east and west or (b) northwest and southeast; the second, accompanying or following the rhyolite intrusions, trend in the same directions as the first, but are most marked in a (c) northwest or (d) northeast direction. Still later, after ore deposition, northeast fracturing occurred.

The earliest fracturing recognized is that which is assumed to have taken place in the partly consolidated mass of Butte quartz monzo- 
nite, causing openings which were filled by the analogous but more acidic magma that cooled as aplite.

The rhyolite porphyry intrusion, which probably took place after both the Butte quartz monzonite and the aplite had been consolidated, formed irregular dikelike bodies which have a general northwest trend, though the one in the Anaconda mine runs east and west.

The most important fracturing - that which formed the fissures that admitted the earliest mineral-bearing solutions--occurred subsequent to both aplite and rhyolite porphyry intrusions.

Subsequent to the original deposition of minerals along the vein fissures several dynamic movements took place, each producing fracturing which affected the mineral deposits. These later movements have formed cross fissures faulting the earlier veins and strike fissures coincident with or parallel to and reopening earlier veins. Important mineralization has taken place also along cross fissures.

The volcanic outbreak which caused the rhyolite intrusion occurred subsequent to the earlier vein fissuring, as is shown by the fact that the silver veins are cut off, in places even cut in two, by the intrusive dikes of rhyolite. The relation of these rhyolite dikes to the different periods of late fracturing is, however, not positively known. More than one postmineral movement took place, for the rhyolite dikes have been markedly sheeted and somewhat fractured since their intrusion. The rhyolite intrusion itself, however, was probably accompanied by a certain amount of fracturing of the adjoining rocks. It is therefore not improbable that the secondary fracturing, which had an important bearing on the enrichment of the copper veins, was genetically connected with the intrusion of the rhyolite. ${ }^{1}$

The ores are of two distinct classes, copper and siliceous silver. The copper ores contain a little silver; the silver ores rarely contain copper; both copper and silver ores contain a little gold, and the highgrade silver ores contain it in important amounts. ${ }^{2}$

Chalcocite, enargite, and bornite are the most common copper minerals. Covellite occurs in large amounts in one mine and in small amounts in others. Chalcopyrite is present in workable quantities in a few properties but is an insignificant part of the total copper output. Tetrahedrite is found as a rarity in the deep workings of a few mines. Chalcanthite, or native bluestone, is common in the old workings. Pyrite is the most common sulphide. It is estimated that since the beginning of mining about 75 per cent of the copper production has come from glance, 20 per cent from enargite, 4 per cent from bornite, 0.5 per cent from covellite, and 0.5 per cent from chalcopyrite. 
Silver occurs native in the copper ores, especially in those from the upper levels. Ruby silver and indeterminable black sulphantimonites and arsenides occur in the siliceous silver ores. Free gold is rare but occurs in some silver ores and has been seen in specimens from the Leonard mine, where it is parasitic on glance. ${ }^{1}$ The gangue minerals include quartz, sericite, and several residual minerals of the altered country rock. Rhodonite and rhodochrosite occur in silver ores.

The mountains near by have been glaciated in recent geologic time, but no morainal material is found in the immediate vicinity of Butte. $^{2}$

The average precipitation is less than 20 inches, but the loose disintegrated material near the surface favors extensive seepage of rain water. The fow records of "first water" for the older mines appear to locate it at about the upper limit of the sulphide ores. This upper limit varies greatly, ranging from about 20 feet to 400 feet, being in part independent of the surface level but varying with the degree of fracture.

In the quartz monzonite the network of lesser fractures and the veins and faults are apparently all filled with water and serve as a vast reservoir. That this water has a natural level not far below that of the neighboring valleys is evident, and that it is moving slowly downward can not be doubted, though it can not be readily proved. The conditions of mineralization afford some evidence of this; and in the East Ridge region, where higher collecting ground exists, the springs became dry when the Altona mine was pumped out to a depth of some 200 feet, proving a connection between the mine waters and surface drainage. The drying out of the upper workings of some of the mines when the surface seepage is eliminated shows that in these mines the waters come from above. In short, all the evidence shows that the waters are surface waters seeping downward. They come, however, from a broad area, and not from the surface of the Butte mines alone. ${ }^{3}$

In opening new ground the amount of water, as stated by Weed, seems to be proportionate to the block of ground opened-that is, the ground between the new level and the old workings above. In a few places rising water was encountered at the deeplevels - for instance, on the 2,200-foot level of the Mountain Con. mine and on the 1,600foot crosscut of the Anaconda (where uprising waters were encountered some 2,000 feet from other workings) - but the outflow dininished in a few weeks and finally all but ceased, indicating that the area from which the water came was probably drained. ${ }^{4}$

The oldest deposits are the east-west lodes, of which the Parrot, Anaconda, and Syndicate are examples. These occupy fissures along 
which there was but slight tangential movement. ${ }^{1}$ The ore minerals in these veins consist chiefly of pyrite, chalcopyrite, chalcocite, covellite, etc. Pyrrhotite is not mentioned in the descriptions of these or any later deposits. I am informed by Mr. Reno Sales that sphalerite is widespread and abundant in the copper veins except in that part of the district extending from the Neversweat mine eastward through the Anaconda, St. Lawrence, Mountain View, Pennsylvania, Leonard, and Silver Bow mines. In these properties it is almost entirely absent, both in these and later vein systems. Westward, in the Steward, Original, and Gagnon ${ }^{2}$ mines, sphalerite is abundant, as it is in the Colorado, Clear Grit, Buffalo, and Paulin mines and also in many of the silver lodes.

A later set of veins strikes northwest across the east-west veins. These contain, in addition to the minerals named as constituents of the earlier veins, large quantities of enargite. Along these veins evidence of movement parallel to the planes of the deposit is more pronounced. Although mineralization of the earlier veins is comparatively uniform, the later veins are characterized by barren patches separating rich ore shoots. These ore shoots, as shown by Sales, ${ }^{3}$ are of primary origin, the course of the mineralizing solutions having been determined by fault gouge which effectively dammed back the waters from the portions of the fissures that are barren.

A still later set of fissures, having a northeast course, has displaced both earlier sets. This system, according to Weed, ${ }^{4}$ contains little endogenous ore, but the material mined is mainly fault breccia from earlier deposits. In many of the veins later movement is pronounced.

The depth of oxidation of the copper deposits is treated briefly on page 37. The leached zone extends downward in places 300 or 400 feet below the surface. It contains some silver but little copper. Below the oxidized zones enormous masses of chalcocite, with some bornite and covellite, were encountered.

In the great ore bodies of the upper levels of the Anaconda veins chalcocite occurred, according to Weed, ${ }^{5}$ in masses of nearly pure leadlike mineral 20 feet or more wide. In depth the mineral shows a more crystalline structure, and it is found in all the mines in greater or less abundance and purity, but in the great bulk of the ores it forms small grains scattered through the ores.

Emmons, Weed, Tower, and many others who studied the copper lodes in the earlier stages of their development regarded the chalcocite ores as secondary deposits formed by descending waters. Weed ${ }^{\circ}$

1 Sales, Reno, Ore shoots at Butte, Mont.: Econ. Geology, vol. 3, 1908, p. 327.

2 Pearce, Richard, The association of minerals in the Gagnon vein, Butte City, Mont.: Trans. Am. Inst. Min. Eng., vol. 16, 1888, pp. 62-64.

Sales, Reno, op cit., p. 326.

4 Weed, W. H., The copper mines of the world, New York, 1907, p. 326.

- Idem, p. 327.

- Idem, p. 328. 
says, "As a general statement it may be said that the deposits of copper glance are secondary."

C. T. Kirk, ${ }^{1}$ after a comprehensive study of the ores of the Pittsmont mine of this district, concluded that the chalcocite was secondary, basing his argument in part on its association with kaolin.

As a result of microscopic studies of polished surfaces of ores, John F. Simpson ${ }^{2}$ concluded that the copper sulphides were deposited in the following order: Chalcopyrite, enargite, bornite, chalcocite. Pyrite from the 2,000-foot level of the Mountain Con. mine is cut by veinlets of bornite and contains flakes of chalcocite. In ore from the 800 -foot level of the Alex Scott mine chalcocite surrounds pyrite, enargite, and chalcopyrite and occurs as veins in the pyrite.

As the underground workings have been carried deeper, and as chalcocite ores have been developed in depth, doubt has been expressed more and more as to the validity of the conclusion that the chalcocite ores are wholly secondary. Graton ${ }^{3}$ in 1906 called attention to the fact that on the whole the copper veins in depth are dry. Sales ${ }^{4}$ in 1910 advanced the opinion that the chalcocite in the lower levels of the lodes is primary. Mr. H. V. Winchell informs me that he has reached the same conclusion. Weed ${ }^{5}$ mentions a fine body of chalcocite ore on the 2,400-foot level of the Anaconda group, and later developments, according to Sales, have exposed chalcocite 2,800 feet deep. One of the photomicrographs from a deep level figured by Simpson shows pyrite inclosing small chalcocite masses in relations that are hard to reconcile with the conclusion that the chalcocite is of later age. In a collection of the School of Mines, University of Minnesota, ores from deep levels at Butte show covellite intergrown with tetrahedrite and chalcocite intergrown with pyrite, and there is no evidence that any of these minerals are replacements of older sulphides.

In Weed's most recent report on the district ${ }^{6}$ he states that the bulk of the ore is altered quartz monzonite containing disseminated grains and veinlets of chalcocite intergrown with pyrite or replacing that mineral completely. He also notes that chalcopyrite is but sparingly developed, constituting but 0.5 per cent of the ore mined. The copper of the secondary ore must therefore have been derived in the main from enargite, cupiferous pyrite, or alder chalcocite.

\footnotetext{
1 Kirk, C. T., Conditions of mineralization in the copper veins at Butte, Mont.: Econ. Geology, vol. 7, 1912 , p. 35.

Simpson, J. F., The relation of copper to pyrite in the lean copper ores of Butte, Mont.: Econ. Geology, vol. 3,1908, p. 635 .

8 Graton, L. C., Mineral Resources U. S. for 1906, U. S. Geol. Survey, 1907, p. 400.

4 Sales, Reno, Superficial alteration of the Butte veins: Econ. Geology, vol. 5, 1910, p. 15.

6 Weed, W. H., The copper mines of the world, New York, 1907, p. 331.

- Weed, W. H., Geology and ore deposits of the Butte district, Mont.: Prof. Paper U. s. Geole Survey No. 74, 1912, p. 76 .
} 
A drawing by Bard ${ }^{1}$ shows an inch vein of chalcocite cutting quartz. The chalcocite incloses idiomorphic crystals of pyrite and quartz, and both of these minerals seem to be spaced with some regularity in the chalcocite. The spacing suggests eutectic structure and the relations appear to be nearly identical with those in an ore from Mexico, described by D. P. Hynes, ${ }^{2}$ where tetrahedrite incloses quartz. Although Weed believes that chalcocite is mainly secondary at Butte, he also recognizes its primary origin. He says: ${ }^{3}$

From the studies made of thin sections it is believed that the mineral is almost universally secondary but that it also occurs as a primary mineral in some veins. It is undoubtedly in process of formation by descending waters at the present time, but as the great ore bodies found at deep levels are far below the present level of ground water they can not have been produced by the reactions commonly offered in explanation.

It should be noted here, however, that the history of vein formation at Butte and also the recent physiographic history of the Butte district are exceedingly involved, a fact that diminishes somewhat the value of generalizations for solving the problems of ore formation.

Some of the veins have been depressed by faulting ${ }^{4}$ more than 500 feet since they were formed. Evidence of descending water and of extensive solution and recent deposition is found at unusual depths. Watercourses are shown in some veins over 2,000 feet below the surface.

The physiographic history of the region has doubtless been favorable to a very deep descending circulation. In a previous paper ${ }^{5}$ Weed says:

The region has passed through several very pronounced changes in elevation since the formation of the veins in Tertiary time. In early Tertiary time the present topography was blocked out and the mountain ranges and deep intervening valleys were carved. This was succeeded by earth movements by which the streams became clogged or the valleys dammed, forming lakes; while volcanoes broke out at numerous places and showered ashes and scoria over the region. The valleys were silted up or in part filled by volcanic débris, before crustal movements drained the valleys and altered the divides. More recent movement, possibly still continuing, is marked by faults and a reversing of stream courses. The old valley at Butte is filled by hundreds of feet of débris, and a mountain wall 2,500 feet high marks a north and south fault line. These changes all caused a migration of water level facilitating the processes of weathering and enrichment, and the great bodies of rich copper ores of the region are believed to be in part due to this cause.

In 1907, according to Graton, ${ }^{\circ}$ the copper ores averaged 2.75 per cent copper, 2.3 ounces silver, and 0.014 ounce gold to the ton. Few data are available on the downward migration of gold and silver in the deposits. Although manganese minerals are abundant

\footnotetext{
1 Weed, W. H., loc. cit. The original is not available to me.

2 Hynes, D. P., Notes on the geology of the Mina Mexico vein: Econ. Geology, vol. 7, 1912, pp. 280-286. See also this bulletin, p. 46.

${ }^{8}$ Weed, W. H., loc. cit.

Weed, W. H., op. cit., p. 111.

'Weed, W. H., The enrichment of gold and silver veins: Trans. Am. Inst. Min. Eng., vol. 30, 1901, p. 448

Graton, L. C., Mineral Resources U. S. for 1907, pt. 1, U. S. Geol. Survey, 1908, p. 610.
} 
in the silver lodes that surround the silver-bearing area, it is said that the principal copper ores do not contain manganese, ${ }^{1}$ and the solution of gold in them presumably has been delayed.. To judge from. their position, some, at least, of the gold placers that were worked. in the early days at Butte were derived from the waste of the copper lodes. The valuable metal in the oxidized ore of the copper lodes was chiefly silver, the gold being of subordinate value.

\section{BINGHAM, UTAH.}

The Bingham district, Utah, ${ }^{2}$ is an area of Carboniferous quartzites and limestones intruded by monzonite and monzonitic porphỳry and covered in part by andesites, andesitic porphyries, and breccias. The rocks are tilted, faulted, and in places highly shattered.. The ore deposits are in or near the intrusive monzonite or monzonitic porphyry. They include fissure veins in several formations, bedding-plane deposits in limestones, and disseminated deposits in shattered porphyry. The ore bodies that until recently have been most productive are large replacement deposits of sulphide ore in limestone. These ores consist chiefly of pyrite, chalcopyrite, sphalerite, and chalcocite, with a little bornite and enargite and their oxidation products. In many of the deposits a little pyrrhotite is present, and in some ore from the Highland Boy mine pyrrhotite is more abundant than pyrite and somewhat more abundant than chalcopyrite. $^{3}$

In some of the mines oxidation is deep, extending to depths several hundred feet below the surface. In the Brooklyn mine ${ }^{4}$ oxidation is reported to a depth 1,450 feet below the surface; in the Highland Boy it is only 300 feet deep. In some of the deposits chalcocite ores extend to considerable depths and in others they are subordinate. The chalcocite zone in the Highland Boy seems not to have been extensive. Boutwell notes that the secondary oxidized ores of copper and gold pass into a zone characterized by chalcopyrite tarnished and coated with bornite and seamed with limonite. A winze sunk through oxidized ore encountered gold in considerable quantities, some of the ore running over $\$ 30$ to the ton. Five thousand tons of ore shipped early in the development of this mine are said to have averaged 12 per cent copper and $\$ 4$ gold to the ton and to have contained much silver. It is reported also that the valuable metals in each of the three principal ore bodies ran higher in the upper than in the lower levels. The ores of the lower levels carried pyrite,

1 Pearce, Richard, The association of minerals in the Gagnon vein, Butte City, Mont.: Trans. Am. Inst. Min. Eng., vol. 16, 1888, p. 63. Emmons, S. F:, Notes on the geology of Butte, Mont.: Idem, p. 55.

2 Boutwell, J. M., Economic geology of the Bingham mining district, Utah: Prof. Paper U. S. Cieol. Survey No. 38,1905 .

3 Idem, p. 105.

I Idem, p. 215.

$72293^{\circ}-$ Bull. $529-13-12$ 
pyrrhotite, chalcopyrite, considerable gold, and some silver. In 1906 and 1907, according to Graton, ${ }^{1}$ practically all the copper from these deposits was derived from the pyritic ore.

Another type of ore deposit which in recent years has become highly productive contains copper ore disseminated in the monzonite porphyry. The principal deposit of disseminated ore is in the intrusive body at Upper Bingham known as the Bingham laccolith. According to Boutwell ${ }^{2}$ this extensive mass of monzonite carries disseminated throughout its areal extent, so far as known, irregular grains of pyrite and chalcopyrite. The mineralized tract contains a multitude of thin unsystematized parting planes. The rock is greatly bleached, silicified, and sericitized in and near the areas of great shattering. The copper content is lowest in the oxidized zone at the surface. Farther down, in the unoxidized rock, the copper ore lies in flat scales and films in silicified walls of cracks, and in areas of great shattering it occurs abundantly on quartz-coated cracks and is disseminated through the silicified bleached walls. The quartz, the sericite, and possibly the biotite in this ore are later than the original rock-making minerals. I can find no record of the occurrence of pyrrhotite in these ores. Zinc blende is not mentioned in Boutwell's description of this deposit, although it is abundant in some of the lode ores in the monzonite-for example, in that of the Last Chance mine. ${ }^{3}$ Although some of the metals may have been present in the rock when it solidified, 4 the larger part of the primary sulphides was introduced by thermal waters after the porphyry had solidified.

Of the surface alteration of disseminated ores Boutwell says: ${ }^{5}$

Superficial alteration has followed the deposition of chalcopyrite and pyrite. Pyrite about its periphery and along cracks which traverse these planes may be seen going over to limonite. This fact $* * *$ doubtless explains the relative enrichment of gold values proved by assays to exist in the outer or surface portions of test tunnels in these copper and gold bearing intrusives. The brilliant tamish of grains of chalcopyrite indicates a beginning of alteration, and thin rims of a dark grayishblack metal about chalcopyrite observed under the microscope suggest continuance of that process and replacement by black copper sulphide. Rims of a blue-black metallie sulphide occur around grains of chalcopyrite. The reason for the decrease in assay values of copper along certain open and water-bearing fracture zones is doubtless to be found in the well-known. fact that under the action of surface waters copper suffers rapid alteration and transportation.

It appears, then, that in the disseminated ores in igneous rock the copper minerals were deposited by hydrothermal action subsequent to the date of igneous intrusion, and that these sulphides are now undergoing normal superficial alteration.

The Utah Copper Co., which is exploiting the ores of the Bingham laccolith, is said to have developed about $300,000,000$ tons, the

1 Graton, L. C., Mineral Resources U. S. for 1906, U. S. Geol. Survey, 1907, p. 404; idem for 1907, pt. 1, 1908, p. 615 .

2 Boutwell, J. M., op. cit., p. 167.

${ }^{8} \mathrm{Idem}$, pp. 160, 178 .

4 Idem, p. 171.

6 Idem, p. 172. 
average content of which is about 1.5 per cent copper and from 20 to 30 cents a ton in gold and silver. The surface of this ore body occupies an area of 214 acres and the average thickness of the workable ore is probably about 418 feet. $^{1}$

The leached capping, which is stripped by steam shovels, has an average thickness of 80 feet on the Utah ground, 160 feet on the Boston Consolidated ground, and 173 feet on the Pay Roll ground, the average for the entire area being 106 feet. The mine figures indicate that the average depth of the bottom of the deposit now workable is more than 500 feet below the surface, although it extends downward in places more than 900 feet below the surface. ${ }^{2}$ In much of the ore, especially in that of lower levels, chalcopyrite is an important ore mineral, and considerable masses of the ore carry very little chalcocite. It is not known whether the chalcopyrite is a primary or secondary sulphide.

In 1911 the Utah Copper Co. produced from copper ore about a million dollars in precious metals, four-fifths of which was gold and about one-fifth silver. This is equivalent to about $\$ 0.225$ per ton of ore and 1.07 cents per pound of copper. It is said that gold values are concentrated in the oxidized zone, but below it they tend to increase or decrease with the copper content of the sulphide ore.

\section{BISBEE, ARIZONA.}

The geology of the Bisbee (Warren) district, Arizona, was studied in detail about eight years ago by Ransome. ${ }^{3}$ Since the publication of his report the known productive area has been much extended and large new mines have been developed, especially in a part of the district to whose economic possibilities this report specifically directed attention. In view of these later developments Mr. Ransome, who revisited Bisbee in 1912, has kindly prepared the following note, in which is presented more recently acquired information than could have been included in a mere abstract of published work.

\section{NOTE ON THE BISBEE DISTRICT, ARIZONA.}

\section{By F. L. Ransome.}

The fundamental rocks of the Bisbee district are the pre-Cambrian Pinal schist and probably also the granite mass of Juniper Flat, north of Bisbee, which is intrusive into the schist. Although the age of this granite is not directly evident from its geologic relations and although in Professional Paper 21 and in the Bisbee folio it was regarded provisionally as Mesozoic, the texture and character of

1 Seventh Ann. Rept. Utah Copper Co., for 1911.

2 See cross section, idem.

a Ransome, F. L., The geology and ore deposits of the Bisbee quadrangle, Arizona: Prof. Paper U. S. Geol. Survey No. 21, 1904; Bisbee folio (No. 112), Geol. Atlas U. S., U. S. Geol. Survey, 1904. 
the rock, in the light of subsequent experience in Arizona, suggest pre-Cambrian age. Resting on the schist in successive upward sequence are (1) the Bolsa quartzite (Cambrian), 430 feet thick; (2) the Abrigo limestone (Cambrian), 770 feet thick; (3) the Martin limestone (Devonian), 325 feet thick; (4) the Escabrosa limestone (Mississippian, "Lower Carboniferous"), 700 feet thick; and (5) the Naco limestone (Pennsylvanian, "Upper Carboniferous"), 3,000 feet or more thick. These beds were intruded in early Mesozoic time by stocks, dikes, and sills of granite porphyry and, after deep erosion, were covered by a thick series of Cretaceous (Comanche) beds. These have in greater part been eroded away from the productive area of the district.

Structurally the district is characterized by numerous faults, some older and some younger than the Cretaceous beds. In some of the tilted fault blocks the strata are gently folded, but folding is a much less conspicuous feature of the structure than faulting.

The primary ores were deposited during or after the intrusion of the granite porphyry and before the deposition of the Cretaceous beds. Their age is therefore early Mesozoic. Their deposition was connected with a decided but not conspicuous contact metamorphism of the limestones, shown by the development within these of tremolite, diopside, garnet, and other silicates, generally in crystals of microscopic size. The ore bodies that first gave prominence to Bisbee are those in the Carboniferous and Devonian limestones, but recent developments are bringing to light important lenticular masses of ore in the Cambrian limestone, and a little ore has been found in the porphyry.

Very briefly stated, the larger structural features to which the occurrence of the ores is related are (1) the northwest-southeast Dividend fault, with a normal throw that has brought Paleozoic beds on the southwest side of the fissure against Pinal schist on the northeast side; (2) a small stock of granite porphyry intruded on the line of the fault and invading the contiguous schist and Paleozoic beds; (3) an open synclinal structure in the down-faulted Paleozoic beds, which is such that these dip in part toward the porphyry stock and in conjunction with the fault plane form a trough pitching to the southeast; and (4) a gentle tilt to the southeast, as shown by the present slope of the pre-Comanche erosion surface. The ore bodies occur in the down-faulted fragment of a syncline, are disposed in roughly semicircular fashion around the porphyry stock, and have radial prolongations along certain zones of fissuring.

While very irregular in form, the ore masses as a rule are roughly lenticular and tend to conform with the bedding of the limestones. The average thickness of all the ore bodies has been calculated by the engineers of the Copper Queen Co. to be about 33 feet. The shape 
and position of many of the bodies, however, are determined by zones of fissuring and by the form of intruded porphyry masses, many of which do not extend directly upward to the surface. 'With possibly a few relatively unimportant exceptions, the known Bisbee ore bodies were originally deposited as metasomatic replacements of the limestones. In many of the ore bodies in the Abrigo limestone the positions of former bedding planes are clearly shown by a banding in the ore.

At the Copper Queen mine, near the northwest end of the structural trough, the ore bodies came to the surface. As development was pushed south and east, around and beyond the exposed porphyry mass of Sacramento Hill, through the Holbrook, Spray, Irish Mag, Gardner, Oliver, Lowell, Hoatson, and Junction shafts, the ore was found at greater depths. The great ore body of the Junction mine of the Calumet \& Arizona Co., south of Sacramento Hill, whose existence was unknown when Professional Paper 21 was written, extends from a point 10 feet above the 1,300-foot level to the 1,500foot level. It is 500 feet long and from 10 to 120 feet wide in plan, part of this width being due to duplication by faulting. South of the curved chain of mines mentioned lie the Briggs and other important ore bodies connected with zones of north-northeast and southsouthwest fissuring in the limestone. In the Briggs mine the ore bodies grade outward into a huge partly oxidized mass of pyrite about 1,500 feet long and in places 800 feet wide.

In the Copper Queen, Lowell, and Hoatson mines the ore bodies are, as a rule, confined to the vicinity of intrusive masses of porphyry. 'In the Junction mine the connection between ore and porphyry is less close and in the Briggs mine no porphyry is known. Apparently the bodies of porphyry, like the fissures in the limestones, played an important part in controlling the movements of the ore-bearing solutions, but it is not believed that any considerable part of the ore constituents came from the porphyry masses now visible; the metallic elements and sulphur had a more distant source.

Up to the year 1904 nearly all the copper obtained at Bisbee came from oxidized or enriched ore. Of late years, however, primary ores have become very important. The Junction ore body, in which the present stopes average over 9 per cent of copper, is a nearly solid mass of sulphides that are mostly primary. The huge pyritic mass of the Briggs mine, with its included bodies of more cupriferous material, is largely primary, and the ore lenses in the Abrigo limestone have, as a rule, undergone no enrichment.

The most abundant sulphides in the primary ore are pyrite and chalcopyrite. With these may be associated considerable bornite and in certain ore bodies magnetite. Of late years both sphalerite and galena have been found in considerable quantity near the porphyry of 
Sacramento Hill, but these minerals are not widely distributed in the copper ores. No pyrrhotite has been noted.

The altitude of this district ranges from 5,000 to 7,400 feet above the sea. The average rainfall is about 17 inches and the surface of the ground water as a rule lies deep. Water was reached in the Lowell mine at a depth of 1,100 feet. Afterward the Junction shaft, 1,800 feet deep, drained the Lowell. For a time, when the lower Junction levels were kept open, the pumps raised over 6,000,000 gallons in 24 hours.

The natural ground-water surface and the lower limit of oxidation are neither coincident nor parallel. In general in the northern part of the productive area much enriched sulphide ore lies above the original water level, and in the southern part there is considerable oxidized material below it. In the Junction mine, for example, there is oxidized and leached material on the 1,500-foot level (corresponding to a depth of 1,750 feet in the Lowell shaft), and oxidized ore is mined in places on the 1,600-foot (bottom) level of the Lowell mine. The lower depth of oxidation ranges from 200 feet to at least 1,600 feet.

Although the relative importance of the enriched chalcocitic ores at Bisbee has been diminished by the discovery of large bodies of profitable primary ore, they still supply a large proportion of the total copper produced. The lower limit of enrichment is irregular and ill defined but, like the lower limit of oxidation, is deeper in the southern part of the productive area than in the northern part. Secondary chalcocite occurs in the bottom level of the Lowell mine (1,600 feet) and on the 1,300-foot level (1,400 feet deep) of the Briggs mine. How much deeper it may go is not known. In some places sulphide enrichment has worked down to the bottom of a pyritic ore body; in others it has worked around and under residual masses of unenriched pyritic material; and in parts of the Briggs mine large masses of leached and oxidized material rest directly on unenriched, low-grade pyrite. The enriching mineral is generally chalcocite. In some loose, friable ore the chalcocite may occur as thin shells around grains of pyrite and as a sooty interstitial powder. Elsewhere the replacement is more nearly complete, the original chalcopyrite and much or all of the pyrite having been converted into massive chalcocite. Secondary chalcopyrite has been noted, ${ }^{1}$ but the greater part of this mineral is probably a primary constituent of the Bisbee ores.

The great depths to which oxidation and enrichment have penetrated at Bisbee and the inclined position of these zones of alteration with reference to the present underground water level and their approximate parallelism with the old pre-Comanche erosion surface indicate that much of the oxidation and enrichment were effected before the deposition of the Cretaceous formations.

${ }^{1}$ Ransome, F. L., The geology and ore depostts of the Btsbee quadrangle, Arizona: Prof. Paper U. $\mathbf{s .}$ Geol. Survey No. 21, 1904, p. 132. 


\section{GLOBE AND MIAMI, ARIZONA.}

For the following note I am also indebted to Mr. Ransome, who studied the Globe district ${ }^{1}$ some years ago and who is now investigating the Miami copper deposits.

THE GLOBE AND MIAMI DISTRICTS, ARIZONA.

By F. L. Ransome.

In the Globe quadrangle, which includes the Miami district, a pre-Cambrian crystalline complex, consisting of Pinal schist and various granitic intrusives ranging from quartz diorite to true granite, is unconformably overlain by a thick series of Paleozoic beds. The stratigraphic column as revised after recent work in the adjoining Ray quadrangle is as follows:

Pre-Mesozoic stratigraphic column in the Globe region, Arizona.

Erosion surface.

, Feet.

8. Thick-bedded gray limestone ${ }^{2}$ (Carboniferous)............ 1,000

7. Thin-bedded limestone ${ }^{2}$ (Devonian) .................... 325

6. Quartzite ${ }^{2}$ (Cambrian)................................ 400

5. Cherty, dolomitic limestone ${ }^{2}$ (Cambrian)................ 250

4. Dripping Spring quartzite............. 450

3. Barnes conglomerate................. Cambrian or older $\left\{\begin{array}{l}10-55 \\ 200\end{array}\right.$

1. Scanlan conglomerate.................

These rocks were extensively intruded, probably during the Mesozoic, by diabase, largely as great irregular sills, and were invaded also by certain masses of granite and quartz monzonite, including probably the Schultze granite, although this particular mass is not now in contact with the sedimentary series. All the rocks mentioned were covered wholly or in part by a thick flow of dacite, probably in early Tertiary time.

These rocks are cut by numerous faults, some older and some younger than the dacite.

The copper deposits occur (1) as lodes in schist, quartzite, limestone, and diabase, which, where they pass through or alongside of limestone, as in the Old Dominion mine, may be connected with large replacement bodies in that rock; (2) as disseminations of chalcocitic ore in the Pinal schist near the Schultze granite (Miami and Inspiration mines); (3) as secondary deposits of chrysocolla in dacite tuff (Black Warrior mine) or in fissures (old Live Oak and Keystone workings).

\footnotetext{
1 Ransome, F. L., Geology of the Globe copper district, Arizona: Prof. Paper U. S. Geol. Survey INo. 12, 1903; Globe folio (No. 111), Geol. Atlas U. S., U. S. Geol. Survey, 1904.

8 Namos will be given to these formations in a fortbcoming publication.-F. L. R.
} 
The primary ore of the lodes consists essentially of pyrite and chalcopyrite, with bornite and specularite ${ }^{1}$ of less regular or less abundant occurrence and galena and sphalerite rather rare. In the disseminated deposits in schist the primary metallic minerals are pyrite and chalcopyrite with a littlè molybdenite.

The disseminated primary metallization was undoubtedly connected with the intrusion of the Schultze granite, the constituents of the sulphides probably emanating from the magma reservoir that supplied that rock. The lode ores were also deposited at high temperature and may also be genetically connected with the granitic magma. They are, however, more closely associated with the diabase, and possibly this rock had some share in their genesis. The known ore bodies in limestone have been modified by secondary processes, but their original deposition by replacement was apparently not associated with any important metamorphism of the adjacent limestone. ${ }^{2}$

The altitude of the Globe quadrangle ranges from 3,000 to 7,850 feet and the average annual precipitation is between 13 and 20 inches. The ground-water level is in general deep, although in parts of the areas occupied by the Quaternary Gila conglomerate water is abundant within moderate distances from the surface.' In the Old Dominion mine the original water level was probably between 700 and 800 feet in depth and a large part of the present influx is derived from workings that tap the conglomerate-filled valley of Pinal Creek. In the Miami-Inspiration group of mines the underground water level is not very well defined. Generally some water appears below a depth of 400 feet, but as a rule water is not abundant at depths less than 900 feet.

The ore bodies in limestone of the Old Dominion and neighboring mines have been nearly exhausted. They were large irregular masses of oxide and carbonate ore associated with much limonite and hematite. In the lodes connected with these masses oxidized ore prevails generally to a depth of 700 to 800 feet but extends much deeper, as was predicted in $1903,{ }^{3}$ in the much-faulted ground under the Gila conglomerate, in the western part of the mine, where it is found on the 1,600 -foot or bottom level about 1,200 feet below the surface. It is thus highly probable that much of the oxidation and enrichment at the Old Dominion lode was effected before the deposition of the Gila conglomerate.

\footnotetext{
1 This mineral had been seen at Globe only in association with oxidized ores when Professional Paper 12 was written.-F. L. R.

${ }^{2}$ L. C. Graton (Mineral Resources U. S. for 1907, pt. 1, U. S. Geol. Survey, 1908, p. 596) has stated that the ores in limestone are believed to be of contact-metamorphic origin. I am not in accord with this statement.-F. L. R.

${ }^{8}$ Ransome, F. L., Geology of the Globe copper district, Arizona: Prof. Paper U. S. Geol. Survey No. 12, 1903, p. 148.
} 
Under the oxidized ore in the Old Dominion and adjacent lodes, mainly in diabase, are large bodies of chalcocitically enriched ore which grade irregularly downward into pyrite or into pyritic ore containing chalcopyrite, bornite, and specularite. In places enrichment has not penetrated below 800 feet, but elsewhere it goes much deeper.

The disseminated deposits near Miami, about 6 miles west of Globe, have been proved during the last few years to be of great economic importance. Churn drilling and mining exploration have shown the existence of a chain of large ore bodies extending in a gentle curve from the Miami mine on the east through the Inspiration, Keystone, and Live Oak mines to the west. The extreme western limit of this ore belt is as yet undetermined. The total length of this chain as at present developed is 2 miles, the maximum width is one-fourth mile, and the greatest thickness of ore along any one vertical line is about 300 feet. Estimates by the engineers of the various mines give a total of $80,000,000$ to $90,000,000$ tons of ore averaging between 2 and 2.5 per cent of copper.

As a whole, the ore bodies form an irregularly undulating ribbon of very uneven thickness. The distance from the surface of the ground to the top of the ore varies widely from place to place and is not definitely related to the present topography, which apparently is of later development than the main period of enrichment. At the Miami mine the depth to ore is in general between 200 and 400 feet, on the Inspiration ground it ranges from 50 to 600 feet, and on the Live Oak ground it reaches 1,000 feet. The ore dips generally east in the Miami mine, is on the whole nearly horizontal in the Inspiration mine, but turns down to the west in the Keystone, and this westerly dip increases to $40^{\circ}$ or $45^{\circ}$ in the Live Oak ground. East of the Keystone a zone of strong faulting has stepped down the ore, and at the Miami mine another fault cuts off the ore by bringing the Gila conglomerate down against the schist. There are other important faults in the district, but these can not be described in this brief note.

The surface of demarcation between the leached, more or less rusty, barren schist and the top of the ore is definite, and in many places there has been some slipping between the cappingand the ore. The downward change from ore (above 1.3 per cent copper) to primary material (less than 1 per cent copper) is less definite but takes place within a few feet.

The country rock is in general Pinal schist, but good ore occurs also in dikes and small offshoots that extend into metallized schist from the main granite mass, which grades into granite porphyry on its margins. Over much of the ore-bearing ground this granite porphyry is the surface rock, the ore occurring in the schist beneath it. Clearly this part of the porphyry was intruded as a flat-lying sheet. 
In general the unmetallized Pinal schist is a bright-gray fissile rock, splitting with a lustrous, satiny sheen and showing considerable variations in color, texture, and degree of metamorphism or crystallinity. The essential constituents are quartz, muscovite (sericite), a little microcline and plagioclase, magnetite, zircon, tourmaline, hornblende, biotite, and chlorite. As a whole, the Pinal schist was derived by metamorphism from arkosic sedimentary beds, although it includes here and there a little material of probable igneous origin.

During the primary period of metallization pyrite, chalcopyrite, a little molybdenite, and quartz were deposited in the fractured schists, partly in fissures an inch or so wide but chiefly in much smaller cracks or along cleavage planes. During the period of enrichment the downward-moving cupriferous solutions replaced the chalcopyrite and pyrite wholly or in part by chalcocite.

Final expression of opinion as to the geologic date of the principal enrichment is withbeld, but a preliminary review of the evidence strongly suggests that the enrichment antedated the deposition of the Gila conglomerate and may possibly be older than the dacite. Probably the process has continued to the present day, but where erosion has overtaken the chalcocite zone enrichment apparently has been temporarily checked by the fact that little pyrite is available to form strongly acid solutions and the copper, instead of migrating downward, remains near the surface, coloring the rocks brilliantly with chrysocolla and carbonates. As a rule, the largest ore bodies are not found under those surface rocks that are most vividly colored by copper compounds or by iron oxide.

\section{RAT, ARIZONA.}

By F. L. Ransome.

The disseminated copper deposits of Ray are about 20 miles southwest of Globe, in the hilly depression drained by Mineral Creek, between the Dripping Spring and Tortilla ranges.

The geologic formations are in general the same as those in the Globe quadrangle, the Pinal schist at Ray being intruded by two varieties of granite porphyry, one of which very closely resembles the porphyritic facies of the Schultze granite.

The ore bodies are mainly in the schist, although masses of granite porphyry within the generally metallized area have also been converted to ore.

Within the productive area the altitude ranges from 1,950 to 2,900 feet above sea, and most of the hills are steep and rugged. The climatic conditions are similar to those at Globe. Little information is available concerning. the level of ground water, which is below the principal mine workings. Most of the water that enters the mines appears to be seepage from Mineral Creek and from its tributary, Copper Creek. 
The ore bodies underlie a group of more or less rusty hills stained here and there with salts of copper. The principal area showing this alteration is of elongated oval shape and extends west-northwestward from Mineral Creek for about $2 \frac{1}{4}$ miles with a maximum width of a little more than half a mile. Within this area churn drilling and mining have shown the presence of a continuous ore body about 8,000 feet long and 2,500 feet in greatest width. As at Miami, the layer of ore has many irregular undulations that apparently have no dependence on the present topography and varies much in thickness. The average thickness of the ore body is 101 feet; the average thickness of overburden 250 feet. The depth to ore varies from 10 to 300 feet and the thickness of the ore from 0 to 400 feet. Chalcocite has been reported from one drill hole to a depth of 715 feet and the ore extends under Humboldt Hill to a depth of 700 feet. The quantity of ore in the Ray ore body as calculated by the mine engineers is over $83,000,000$ tons averaging 2.17 per cent of copper, with over 500,000 tons of considerably higher grade.

The relations of the ore to the oxidized leached capping and to the underlying primary material are similar to those at Miami. The ore constituents in the two districts are the same. In both districts the primary metallization continues to unknown depths. As at Miami, the greater part of the chalcocite is disseminated through the schist (or porphyry) in small specks or in minute veinlets with quartz; but here and there are veinlets several inches wide in which the original chalcopyrite and pyrite have been partly or wholly altered to massive chalcocite.

Pyrrhotite, sphalerite, and galena, so far as known, do not occur in the disseminated copper deposits at Ray or Miami.

\section{MORENCI, ARIZONA.}

The Morenci district, Arizona, ${ }^{1}$ is an area of pre-Cambrian granite and quartzitic schists above which rest unconformably about 1,500 feet of Paleozoic sandstones, limestones, and shales that are locally overlain by Cretaceous shales and sandstone. These rocks are intruded by masses of granitic and dioritic porphyries, which form stocks, dikes, laccoliths, and sheets. All these rocks have participated in an uplift and a warping or doming that was succeeded by much faulting, which took place during latest Cretaceous or earliest Tertiary time. Surrounding the domed area of older rocks are great masses of Tertiary lavas consisting of basalt and rhyolite, with some andesite. ${ }^{2}$

The ore bodies are veins and disseminated deposits in the granite and monzonite porphyry and contact-metamorphic deposits in the

1 Lindgren, Waldemar, The copper deposits of the Clifton-Morenci district, Arizona: Prof. Paper J. S. Geol. Survey No. 43, 1905.

Idem, p. 17. 
limestone and shale near the porphyry. The fissure veins and nearly related deposits are most productive. In 1906, according to Graton, over 92 per cent came from the large disseminated deposits and stockworks of chalcocite along shattered zones in altered porphyry. ${ }^{1}$

Lindgren ${ }^{2}$ summarizes the successive stages of mineral formation as follows:

Veins:

Primary processes: Pyrite, chalcopyrite, zinc blende, molybdenite (rarely mag. netite), sericite, quartz (rarely tremolite, diopside, and epidote). Introduction of iron, sulphur, zinc, copper, potassium, and silica; elimination of calcium and sodium.

Processes of oxidation:

Action of sulphate solutions without oxygen: Chalcocite (rarely covellite, chalcopyrite, and bornite), quartz, chalcedony, kaolin, alunite. Introduction of copper; elimination of zinc, some iron and sulphur.

Action of directly oxidizing solutions: Cuprite, native copper, brochantite, malachite, chrysocolla (rarely azurite), chalcanthite, limonite, quartz. Introduction of carbon dioxide; elimination of sulphur, together with some iron and copper.

Contact deposits:

Primary processes: Pyrite, magnetite, chalcopyrite, zinc blende, garnet, epidote, diopside, tremolite, quartz. Introduction of much iron and silica, together with copper, zinc, molybdenum, sulphur, possibly magnesia; elimination of carbon dioxide and probably some lime.

Processes of oxidation: Limonite, malachite, azurite, cuprite, rarely native copper and chalcocite, copper-pitch ore, chrysocolla, goslarite, zinc carbonate, willemite, calamine, pyrolusite, quartz, calcite, chlorite, serpentine. Introduction of carbon dioxide and additional copper; elimination of calcium, sulphur, some zinc, and iron.

The veins rarely show typical gossan or iron cap with an abundance of limonite and rich oxidized ores. ${ }^{3}$ Their outcrops are either entirely barren or contain only a moderate amount of copper, but much richer ore is ordinarily found just above the chalcocite zone. The upper half of the chalcocite ore is richer. It occurs as solid masses and in the porphyry as scattered grains. In both classes of deposits it replaces pyrite and zinc blende, and generally at a depth rarely more than 400 feet below the surface it gives way to these minerals, which form a very low grade unworkable ore. The annual rainfall is about 10 inches. No standing ground-water level has yet been encountered, and the upper parts of the chalcocite bodies are undergoing extensive oxidation.

The deposits in porphyry, as stated by Lindgren, generally show the following arrangements in depth. ${ }^{4}$

1 Graton, L. C., Mineral Resources U. S. for 1906, U. S. Geol. Survey, 1907, p. 388.

2 Lindgren, Waldemar, op. cit., p. 194.

3 Idem, p. 207.

IIdem, p. 201. 
Surface zone ....50 to 200 feet deep from the croppings; contains oxidized copper minerals or is barren.

Chalcocite zone... 100 to 400 feet in vertical extent; possibly more in places; contains chalcocite and pyrite.

Pyritic zone....... Begins 200 to 600 feet below the surface; contains pyrite, chalcopyrite, zinc blende, and molybdenite.

The minerals of the upper two zones have been derived from those of the pyritic zone by processes of direct and indirect oxidation; the chalcocite is derived from replacement of pyrite and sphalerite probably by aid of cupric-sulphate solutions. The surface zone has been derived from the chalcocite zone by its gradual and direct oxidation. The pyritic zone has thus far been found to be poor in copper and rarely makes commercial copper ore; the chalcocite zone produces the richest ore and the richest part of it is near its upper limit; the leached zone is usually poor and sometimes practically barren. These changes with depth may be observed also in the contact-metamorphic ores, but these ores as a rule are not altered to depths so great.

The Coronado vein, which occupies a fault fissure between preCambrian granite and quartzite, differs in many respects from the deposits in the porphyry, and it is suggested by Lindgren ${ }^{1}$ that it probably had a different origin. The ore minerals include pyrite, chalcopyrite, and chalcocite. Sphalerite is not mentioned by Wendt ${ }^{2}$ or by Lindgren as a vein constituent, although it appears in appreciable quantities in other ores in this district. Lindgren notes that chalcocite ore is found in this vein as deep as 500 or 600 feet below the surface. More recently, according to Tolman, ${ }^{3}$ a chalcocite zone has been found in the Coronado mine considerably deeper than in any other mine in the district.

ELY, NEVADA.

By A. C. Spencer.

The Ely district, Nevada, ${ }^{4}$ is an area of folded and faulted Paleozoic limestones and shales ranging in age from Silurian to Carboniferous. These formations are intruded by monzonite porphyry along an eastwest zone about 9 miles long and from one-half to 1 mile wide. These older formations are locally overlain by rhyolite flows of Tertiary age. The sedimentary rocks adjacent to the porphyry intrusions are greatly altered, being locally garnetized or changed to jasperoid and commonly charged with great quantities of pyrite. In places near the igneous masses considerable amounts of chalcopyrite occur with the

1 Lindgren, Waldemar, op. cit., p. 344.

3 Wendt, A. F., The copper ores of the Southwest: Trans. Am. Inst. Min. Eng., vol. 15, 18:37, pp. $28-52$. ${ }^{3}$ Tolman, C. F., The southern Arizona copper fields: Min. and Sci. Press, vol. 99, 1909, p. 390.

- Lawson, A. C., The copper deposits of the Robinson mining district, Nevada: Bull. Dept. Geology Univ. California, vol. 4, No. 14, 1906, pp. 287-357. Spencer, A. C., Preliminary geologic map of the vicinity of Ely, Nev., U. S. Geol. Survey, 1912. 
pyrite, and rarely zinc blende and pyrrhotite accompany these sulphides. Galena and its oxidation products occur in irregular lodes within the metamorphic area, principally at some distance from the porphyry masses. Gold ores, formerly exploited, occur mainly in the form of blanket lodes, the gold being associated with lead carbonate.

Of many superficial showings of copper carbonates none has been developed profitably, but oxidized ores of relatively high grade have been discovered in the Alpha mine of the Giroux Co., at considerable depth. This ore body is inclosed by metamorphosed and thoroughly oxidized sedimentary rocks that lie several hundred feet from the nearest mass of porphyry.

The present importance of the district centers in the low-grade disseminated ores in porphyry. The igneous rock was locally fractured after its intrusion, and great masses of it became infilled with veinlets of quartz carrying pyrite and chalcopyrite. Even away from the fractures the porphyry was charged with sulphides and the rock was greatly altered, with abstraction of lime, magnesia, soda, and iron and with noteworthy addition of potash. These losses and gains involved the destruction of hornblende and lime-soda feldspar and the formation of mica, including brown mica and sericite. The outcrops of the ore masses are yellowish or less commonly red and are said to carry not over 0.5 per cent of copper. There is an abrupt change from this capping to soft bluish-white porphyry ore, which carries disseminated sulphide minerals, including copper glance, as films coating grains of pyrite and chalcopyrite or, less commonly, completely replacing such grains.

One company, the Nevada Consolidated, has developed about $49,000,000$ tons of disseminated ore, the average being 1.7 per cent copper. The variations in depth are indicated in three sections as follows: ${ }^{1}$

Thickness, in feet, of capping and of ore in workings of the Nevada Consolidated Co., Ely, Nev.

\begin{tabular}{|c|c|c|}
\hline Section. & $\begin{array}{l}\text { Average } \\
\text { thickness of } \\
\text { direct } \\
\text { capping. }\end{array}$ & $\begin{array}{l}\text { Average } \\
\text { thickness of } \\
\text { profitable } \\
\text { ore. }\end{array}$ \\
\hline $\begin{array}{l}\text { Eureka } \\
\text { Hecla } \\
\text { Liberty }\end{array}$ & $\begin{array}{r}87.1 \\
101.4 \\
154.7\end{array}$ & $\begin{array}{l}190 \\
280.3 \\
193.3\end{array}$ \\
\hline 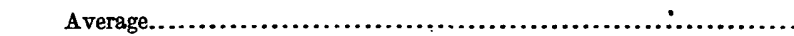 & 102.5 & 217.9 \\
\hline
\end{tabular}

The profitable ore is known to extend locally to depths about 600 feet below the surface. In one place a hole was put down nearly 400 feet below the ore body in material which carried less than 0.4 per cent of copper.

1 Fifth Ann. Rept. Nevada Consolidated Copper Co., for 15 months ended Dec. 31, 1911, p. 8. 
The gold and silver content of the disseminated ores is considerable. In 1911 the average per ton was 0.013 ounce gold and 0.079 ounce silver. Although less than 60 per cent of the precious metals was saved, their value recovered was 17.35 cents a ton.

A composite analysis of 1,000 samples of ore from the Ruth mine shows, as stated by Lawson, sulphur, 6 per cent; iron, 5.3 per cent; and copper, 2.61 per cent, which may be calculated as equivalent to pyrite, 10 per cent; chalcopyrite, 1.8 per cent; and chalcocite, 2 per cent.

It may be stated as a general truth that any porphyry carrying more than 1 per cent of copper owes its grade to the presence of chalcocite, the enrichment having resulted from precipitation of this mineral out of solutions derived from overlying material.

In the porphyry mines the lower limit of complete oxidation is everywhere considerably above the water level, the difference in elevation being about 250 feet in the Ruth mine. While most of the material carrying chalcocite lies above standing water, the bottom of the ore seems to bear no definite relation to the water table. The greatest depth of porphyry ore is about 600 feet, but in the Alpha mine, which lies outside of the porphyry ore, enriched ore was found between the 700 and 1,200 foot levels. Here the water stands somewhat more than 1,000 feet below the surface and most of the lode material is fully oxidized and leached to this depth.

\section{SANTA RITA AND HANOVER DISTRICTS, NEW MEXICO.}

The Santa Rita and Hanover districts, New Mexico, ${ }^{1}$ are adjacent and show similar geologic features. The country is an area of Carboniferous and older sedimentary rocks, consisting of limestone, quartzite, and shale. These are intruded by granodiorite, quartz monzonite porphyry, and related igneous rocks, and along the intrusive contacts garnet zones have developed. Considerable masses of magnetite, pyrite, and zinc blende are present. Pyrrhotite ${ }^{2}$ is found in the Hanover district, and sphalerite has been mined to some extent for zinc. ${ }^{3}$

At Santa Rita most of the copper occurs as native metal, oxide, or sulphide in altered porphyry. Chalcocite with kernels of pyrite is present both in the quartzite and the porphyry.4

As stated by Graton, it is certain that much of the copper that now exists as native metal or oxide was not precipitated on pyrite but must have been deposited from solution in open spaces and in porphyry as replacement along fissures.

${ }^{1}$ Lindgren, Waldemar, Graton, L. C., and Gordon, C. H., The ore deposits of New Mexlco: Prof. Paper U. S. Geol. Survey No. 68,1910, p. 305.

Idem, pp. $53,58,81$.

sIdem, p. 309.

Idem, p. 62. 
Whether or not a mingling of solutions containing hydrogen sulphide or some other soluble sulphide with those containing the copper caused this precipitation is unknown. ${ }^{1}$

The presence in chalcocite ores of cores and kernels of pyrite and, outside the ore bodies, of pyrite in masses similar in distribution to the bodies of ore, as well as in a more disseminated state, and all more or less coated with chalcocite, makes it certain that at least a great part of the chalcocite was precipitated by and replaced pyrite. $^{2}$

In the disseminated ores on the Chino ground some $55,000,000$ tons of ore averaging 2.24 per cent copper are said to be developed. Most of it is near the surface. About 70 per cent, it is said, may be mined with steam shovels. The average thickness of the capping, according to B. S. Butler, ${ }^{3}$ is 82 feet, and the average thickness of the ore below the capping is 107 feet.

The ore is somewhat richer than the disseminated ore in several other districts in the Southwest, but no data are available to show that zinc blende has favorably affected the grade of the concentration. I am informed that sphalerite is present in some of the deposits, but that little or none has been observed in the ore directly below some of the important bodies of disseminated ore.

JEROME, ARIZONA.

\section{By F. L. Ransome. ${ }^{4}$}

At Jerome faulting has effected the relative elevation and exposure of a mass of pre-Cambrian schist, within which the principal ore bodies thus far developed are those of the United Verde mine. On the hillside just west of the mine the schist is unconformably overlain by Cambrian, Devonian, and Carboniferous beds.

In the vicinity of the mine the schist stands nearly vertical, with rather rough irregular cleavage, and strikes a little west of north. At least three varieties are distinguishable-(1) a green rock, schistose on its margins but grading into massive material, which is evidently an altered dioritic intrusive; (2) a rough gray schist with abundant phenocrysts of quartz, apparently an altered rhyolite; and (3) satiny greenish-gray, very fissile sericitic schist that may be a metamorphosed sediment. The ore occurs in varieties 2 and 3 , the main belt of dioritic rock (1) lying just west of the ore bodies. The ore is said to follow as a rule the layers of fine sericitic schist.

The ore shoot as a whole is of oval plan, its total horizontal length being about 1,300 feet and its greatest width 700 feet. Its general trend is north-northwest and it pitches in that direction at an angle

\footnotetext{
${ }^{1}$ Lindgren, Waldemar, Grafton, L. C., and Gordon, C. H., The ore deposits of New Mexico: Prof. Paper U. S. Geol. Survey No. 68, 1910, p. 316.

2 Idem, p. 315.

${ }^{8}$ Butler, B. S., Mineral Resources U. S. for 1910, pt. 1, U. S. Geol. Survey, 1911, p. 205.

- Based on a brief visit in 1912.
} 
of $45^{\circ}$. It has been worked to a vertical depth of 1,200 feet with no sign of approaching exhaustion. This great shoot is in reality a complex of smaller but nevertheless large irregular or lenticular ore bodies, apparently related in part to cross fissuring but showing a general tendency toward parallelism with the schistosity.

The important ore constituent is chalcopyrite, associated with varying proportions of pyrite and sphalerite. Bornite has been reported but was not noted in 1912. Neither galena nor pyrrhotite was observed at the time of visit. The sulphides occur partly in small irregular fractures and along planes of schistosity, but to a large extent they have metasomatically replaced the schist, particularly the fine-grained sericitic variety. The ore contains very little vein quartz or other gangue mineral.

The sulphides mentioned are primary and were deposited in preCambrian time.

Oxidized ore, containing malachite, azurite, and cuprite, extended to a depth of about 400 feet and in its upper part was comparatively rich in gold. Native copper was nowhere abundant. Below the level of complete oxidation there was, according to H. J. 'Stevens, some chalcocitic enrichment with a relatively high proportion of silver, but I was informed at the mine that the chalcocitic zone was not of great economic importance and soon gave place to primary ore.

\section{BURRO MOUNTAIN DISTRICT, NEW MEXICO.}

The Burro Mountain district is in Grant County, southwest New Mexico. The country is arid and lies 5,000 to 8,000 feet above the sea. The main mass of the mountains ${ }^{2}$ consists of pre-Cambrian granite and pegmatite and a dioritic rock which locally is gneissic. These rocks are intruded by monzonite porphyry.

The most important deposits are impregnations and replacements along irregular fractures and zones of crushing. Silica and cupriferous pyrite have been introduced and constitute the primary lodes. Practically all the workable ores are the result of enrichment of this lean pyritic material. Rich oxidized minerals-native copper, cuprite, melaconite (?), chrysocolla, melanochalcite (?), malachite, and azurite-are found at or near the surface, but at greater depth chalcocite and chalcocite-coated pyrite are the ore minerals, and at a still lower level these give way to unaltered pyrite.

In the principal mine at Leopold, which belongs to the Burro Mountains Mining Co.-

the zone of impoverishment or leaching is in most places less than 50 feet deep. The ore on the first or 100-foot level contains more iron and less copper than that on

\footnotetext{
1 Stevens, H. J., Copper handbook, 1909, p. 1369.

2 Lindgren, Waldemar, Graton, L. C., and Gordon, C. H., The ore deposits of New Mexico: Prof. Paper U. $\mathrm{s}$ Geol. Survey No. $68,1910, \mathrm{p}, 320$.
}

$72293^{\circ}-$ Bull. $529-13-13$ 
the 130-foot and 160-foot levels; in fact, it appears less enriched. It was reported in 1905 that the lowest or 210-foot level then being driven, had encountered lowgrade pyritic ore under the enriched ore of the upper levels, but since then important discoveries have been announced. ${ }^{1}$

According to S. S. Lang ${ }^{2}$ the chalcocite ore ends very abruptly against the pyrite-chalcopyrite ore below.

In the district southeast of Leopold, according to Sidney Paige, ${ }^{3}$ the leached ground is 200 feet deep. From this the richer ores extend downward to a depth of 380 feet, where unaltered sulphides are encountered. The water level is variable-from 300 to 500 feet below the surface.

\section{CANANEA, MEXICO.}

Cananea, Sonora, Mexico, is 25 miles south of the international boundary and some 38 miles by rail from Bisbee, Ariz. The country is mountainous and the principal deposits are 5,200 to 6,500 feet above the sea. The climate, although arid, is somewhat more humid than that of Arizona.

The region has had a complex geologic history. An ancient granite is overlain by Paleozoic (?) quartzite and limestone and intruded by diabase, above which are rhyolitic tuffs and rhyolite. Intrusive masses of syenite and syenite porphyry are later than the sedimentary rocks and probably later than the tuffs, and large intrusive masses of diorite and diorite porphyry cut both tuffs and limestones. A later granite porphyry, a granodiorite, a quartz monzonite porphyry, and gabbro and diabase are found in intrusive masses. ${ }^{5}$

Contact metamorphism, with the development of heavy silicates and sulphides, has attended the intrusion of the diorite porphyry, the granodiorite, and the quartz porphyry. Contact-metamorphic deposits are numerous and important, but these are subordinate to the great lodes and disseminated ores in the sericitized and silicified phases of the diorite porphyry. The principal deposits of the latter class lie in a belt 1 to 2 miles wide and 6 miles long, which strikes a little north of west, significantly parallel to the great Eliza fault. The contact-metamorphic deposits are composed of chalcopyrite, sphalerite, bornite, magnetite, hematite, and galena in a gangue of garnet, calcite, hornblende, pyroxene, and other heavy silicates. In general, these deposits show chalcocite enrichment to only very shallow depths. ${ }^{\circ}$

\footnotetext{
1 Lindgren, Waldemar; Graton, L. C., and Gordon, C. H., The ore deposits of New Mexico: Prof. Paper U. S. Geol. Survey No. 68, 1910, pp. 322-323.

${ }^{2}$ Lang, S. S., The Burro Mountain copper district: Eng. and Min. Jour., vol. 82, 1906, p. 395.

3 Paige, Sidney, Metalliferous ore deposits near the Burro Mountains, Grant County, N. Mex.: Bull. U. S. Géol. Survey No. 470, 1910, p. 131.

- Emmons, S. F., Cananea mining district of Sonora, Mexico: Econ. Geology, vol. 5, 1910, p. 312.

- Weed, W. H., The Cananea copper deposits: Eng. and Min. Jour., vol. 74, 1902, pp. 744-745; The Cananea district: Trans. Am. Inst. Min. Eng., vol. 32, 1902, p. 428; The Cananea ore deposits: Eng. and Min. Jour., vol. 76, 1903, p. 383. Austin, W. L., The ore deposits of Cananea: Eng. and Min. Jour., vol. 76, 1903, pp. 310-311. Hill, R. T., The ore deposits of Cananea: Idem, p. 421; Cananea revisited: Idem, pp. 1000-1001.

6 Emmons, S. F., op. cit., p. 355.
} 
The ores in porphyry are composed chiefly of pyrite, chalcopyrite, sericite, kaolin, quartz, and other minerals. Zinc blende, although locally abundant, is erratic in distribution. In these ores chalcocite enrichment is very extensive.

Many of the ore bodies are marked by conspicuous gossan immediately or not far above the deposits. This, I believe, is invariably true of the garnetiferous ores in altered limestone, although in the latter oxidation extends only to shallow depths. Some richer ores of this type are seamed and coated with chalcocite, and possibly some chalcopyrite in these deposits is secondary, but these ores are nevertheless workable at several places, in what appears to be their primary concentration.

In the West Cobre Grande and Kirk mines the development is in both diorite porphyry and limestone. The ores are generally of good grade, but at the 200-foot level there is an apparent falling off in the amount of chalcocite and an increase in the proportion of zinc in the ore, which indicates sulphide enrichment. ${ }^{1}$

The most important deposits of the district are those of the Capote basin, which are almost exclusively fractured zones in sericitized porphyry. The primary ores consist mainly of pyrite with a small admixture of chalcopyrite and in places considerable zinc blende. Their introduction was accompanied by extensive sericitization and silicification of the adjoining country rocks. They occur in closely spaced fractures or shear zones that traverse both eruptive and sedimentary rock, and they are disseminated in porphyry throughout the rock, adjoining fractures. The tenor in copper is so low that it is doubtful if the primary ore could have been mined at a profit if it had not received additional copper by downward migration or sulphide enrichment. ${ }^{2}$

The surface is conspicuously altered by oxidation, which has readily attacked the hydrothermally altered pyritized area. Along the Capote fault zone the ore body is capped by gossan, which lies above porphyry and quartzite. A chimney of ore, large on level 1, was followed down to level 7, where it had decreased in size. This chimney of ore appears to represent a zone of intense fracturing and one peculiarly favorable to concentration. Some of the fracturing is later than primary deposition, for traces of enrichment are found down to the seventh level. ${ }^{3}$

The Oversight ore body is capped by porphyry that is silicified but only slightly stained with iron. The chalcocite ore is found 260 feet below the surface and extends downward at least 300 feet deeper, but its lower limit had not been determined in 1907 . 
The Veta Grande ore body has produced remarkably rich oxidized ore, chiefly cuprite and native copper. Rich ore of decreasing tenor was found as deep as the 500-foot level. "In the middle levels there is much enrichment by chalcocite, but this enrichment has apparently not extended to the lowest level." 1

\section{NACOZARI, MEXICO.}

Nacozari, Sonora, Mexico, is 75 miles south of the international boundary line, in a region of hills and low mountain ranges much like those of Arizona. The country rock consists of volcanic tuffs, breccias, and other igneous rocks, with which are associated subordinate limestones and other sedimentary rocks. ${ }^{2}$

The most important mines belong to the Moctezuma Copper Co., controlled by Phelps, Dodge \& Co. The principal developments are those of Los Pilares mine, at the end of a tunnel about a mile long, which intersects a shaft 600 feet below the surface. The largest deposit is a great semicircular body of relatively low grade ore that appears to conform with a curving fractured mass of monzonite (?) which follows a sheeted zone of faulting and a faulted diabase dike that intersect nearly at a right angle.

The ore in depth is composed of brecciated monzonite (?) the smail fragments of which are cemented by iron and copper sulphides. The principal sulphides are pyrite and chalcopyrite, which in the richer ore are coated with bornite and a relatively small amount of chalcocite. In places the ore contains a little zinc, but lead is not reported to be present. At the surface the outcrop is iron-stained gossan that has locally weathered into the pillars from which the mine derives its name. ${ }^{2}$ As in some other arid regions, the iron ore has become dehydrated at the surface, forming specularite. The stopes of richer ore extend from a short distance below the 100-foot level down nearly to the 500 -foot level. Below this the ore is said to be falling off in grade.

It is thus evidently to secondary enrichment that it owes its quality as pay ore. Above these limits the copper is leached out: within them is the greatest concentration of the richer sulphides and, while they can still be observed in the lower levels of the mine, it is evident to the eye that they are in decreasing proportion.4

According to W. L. Tovote ${ }^{5}$ the chalcocite zone is insignificant.

1 Emmons, S. F., op. cit., p. 347.

2 Emmons, S. F., Los Pilares mine, Nacozari, Mexico: Econ. Geology, vol. 1, 1906, pp. 629-643.

8 Idem, p. 631.

I Idem, p. 636.

-Tovote, W. L., Magmatic origin of ore-forming solutions: Min. and Sci. Press, vol. 104, 1912, p. 602. 


\section{SII VERBELL, ARIZONA.}

The deposits at Silverbell, Ariz., ${ }^{1}$ are in an area of Paleozoic rocks, including limestones, complexly cut by an alaskite porphyry intrusion and by andesite and trachyte dikes and covered by andesite, rhyolite, basalt, and other rocks. Garnet contact zones are developed in limestone near the porphyry. The ore bodies, as stated by Tolman, include contact-metamorphic deposits in limestone, disseminations in porphyry, and fissure veins.

The contact-metamorphic deposits supply most of the ore (1909). These deposits carry chalcopyrite, pyrite, quartz, molybdenite, and occasionally wulfenite. A considerable proportion of this ore is oxidized. Some lean chalcocite deposits are disseminated in porphyry.

\section{SAN FRANCISCO REGION, UTAH.}

By B. S. Butler.

The San Francisco region, Utah, is a large mineralized area in the San Francisco and adjacent ranges in Beaver County, Utah. The sedimentary series consists of Paleozoic limestones, shales, and quartzites. These have been covered by a thick series of lavas of intermediate composition. These formations have been intrudedby quartz monzonite and allied rocks.

The ore deposits may be divided into three general types-(1) replacement deposits in fissures in the quartz monzonite; (2) replacement deposits in the limestone, including contact deposits and replacement deposits along fissures, and (3) replacement fissure deposits in the lavas.

Of the replacement deposits in fissures in the quartz monzonite the ore zone in the Cactus mine is the most important. This consists of a brecciated zone of quartz monzonite that has been greatly altered and replaced by the ore minerals. These consist of the sulphides, pyrite and chalcopyrite, with small amounts of tetrahedrite and galena and abundant specularite in a gangue of quartz, sericite, tourmaline, impure siderite, anhydrite, and some barite. Oxidation has not extended below 100 feet and for the most part is confined to a space within 50 feet of the surface. The principal minerals resulting from the oxidation are limonite, azurite, and malachite, with some native copper. Chalcocite is almost and possibly entirely absent from the deposit.

The O K mine, in the Beaver Lake Range, also works a deposit that lies in quartz monzonite and that is similar to the deposit worked by the Cactus mine except that it contains no specularite and that

1 Tolman, C. F., Copper deposits of Silverbell, Ariz.: Min. and Sci. Press, vol. 99, 1909, pp. 710-712. 
the gangue is quartz and sericite. In this deposit oxidation has extended to much greater depth, fully 200 feet, and covellite and chalcocite replace pyrite and chalcopyrite. The only apparent reason for the difference in the secondary ores here and in the Cactus mine is the presence in the latter of carbonate, which has probably prevented or retarded the downward movement of the copper content of the ores.

The typical contact deposits are composed of pyrite, chalcopyrite, magnetite, and sphalerite in a gangue of garnet, tremolite, and other silicates. In general oxidation has not extended to great depth, probably owing to the massive character of the deposits. The richer ores, however, have resulted from concentration in the oxidized zone.

The replacements along fissures in the limestone are typically leadsilver deposits containing minor amounts of copper and zinc. The ores are largely oxidized to the depth of present developments- 500 to 600 feet. The metal-bearing minerals are principally carbonates but include minor amounts of sulphates.

The Horn Silver mine is on the most important deposit in the volcanic rocks. This deposit occurs along a fault that has thrown the lavas down against the Paleozoic limestone. The lavas have been considerably shattered along this fault, especially in the vicinity of minor cross faulting, but the limestone is relatively massive. The ore deposits have formed largely as a replacement of the brecciated lava. The primary ore consists of pyrite, galena, sphalerite, and minor amounts of other metallic minerals in a gangue of quartz, sericite, and partly altered lava. In the oxidized zone the ores are characteristically sulphates, anglesite being the principal mineral in much of the lead ore. Complex sulphates,. such as beaverite, plumbojarosite, and jarosite, are rather abundant, and the oxidized copper ore carries much brochantite. Zinc is not abundant in the oxidized ores, though some carbonate of zinc occurs. In the secondary sulphide zone the copper ore consists of covellite and chalcocite, partly or wholly replacing sphalerite, wurtzite, pyrite, and, to a slight extent, galena. Rich copper ores were mined to a depth of about 750 feet, and enrichment along favorable channels has extended much deeper. The rich zinc ores of this mine are composed of sphalerite and wurtzite, together with the sulphides of other metals in variable quantities. The wurtzite is apparently secondary, commonly forming around cores of sphalerite, and the richer ores have resulted from the addition of the zinc in the wurtzite. Normally the zinc enrichment extends to greater depth than the copper enrichment, and secondary zinc sulphide has been replaced by secondary copper sulphides.

The Beaver Carbonate mine, another replacement deposit in the volcanic rocks, is similar in occurrence to the Horn Silver deposit, 
except that both walls are of the volcanic rock. In this deposit enrichment has been slight, apparently owing to the presence of a local water table very near the surface.

\section{SHASTA COUNTY, CAXIFORNIA.}

The copper-bearing region of Shasta County, Cal.,1 is an area of sedimentary rocks complexly intruded by several varieties of consanguineous igneous rocks. The oldest sedimentary series comprises the Kennett formation (Middle Devonian), which consists chiefly of black fissile shale, with scattered lenses of light-gray limestone and numerous gray or yellowish beds of tuffaceous material. Overlying the Kennett formation unconformably is the Bragdon formation (Mississippian), which consists chiefly of black and gray shales, with thin interbedded layers of tuff and sandstone and bands of conglomerate. Above the Bragdon is the Pit shale, of Middle and Upper Triassic age, consisting chiefly of shales with interbedded layers of volcanic tuff.

The oldest igneous rock is an altered andesite called by Diller the meta-andesite, which underlies and is older than the Kennett and Bragdon formations. A massive, less-altered andesite (Dekkas andesite) overlies the Bragdon and underlies and grades into the Pit. Younger than all these rocks and cutting the latest of them, the Pit shale, are intrusives of soda-rich alaskite porphyry, or soda granite. The alaskite porphyry is cut by quartz diorite, which in turn is cut by acidic and basic dikes that are genetically very closely related to the alaskite porphyry and to the pegmatites of the region. These pegmatites, according to Graton, ${ }^{2}$ are more acidic than the present quartz diorite and in places "pass over into siliceous masses that are virtually quartz veins and carry sulphides."

There are two centers of alaskite porphyry, and each is a center of ore deposition.

The important copper deposits consist of large masses of pyritic ore, surrounded in most places by alaskite porphyry but here and there extending into shale. The ores are of medium richness, yielding at present an average of about 3 to $3 \frac{1}{2}$ per cent of copper and $\$ 1.50$ to $\$ 2$ per ton in precious metals, generally about equally divided between gold and silver. ${ }^{3}$

The ores were probably formed about at the close of the Jurassic or the beginning of the Cretaceous. They are in part replacements in shattered zones of alaskite porphyry which is highly altered by sericitization (soda sericite). The deposits are mineralogically simple. Pyrite is the most abundant ore mineral, and chalcopyrite is the chief one that gives the ores their copper value. Sphalerite or zinc blende

2 Diller, J. S., Redding folio (No. 138), Geol. Atlas U. S., U. S. Geol. Survey, 1906. Graton, L. C., The occurrence of copper in Shasta County, Cal.: Bull. U. S. Geol. Survey No. 430, 1910, pp. 71-11.1.

3 Graton, L. C., op. cit., p. 86.

Idem, p. 89. 
is also present in.varying amount; on the average it possibly exceeds the chalcopyrite. Some galena is associated with the zinc sulphide, especially in the eastern districts of the region. The gangue minerals are gypsum, calcite, and barite. The minerals which have resulted from the alteration of the primary ore minerals include limonite, magnetite, wad; secondary chalcopyrite, bornite, and chalcocite; cuprite; native copper; small amounts of malachite and azurite; and several sulphates.

In some of the ore bornite, chalcocite, and chalcopyrite are intergrown. The two richer copper sulphides are very commonly intergrown with the chalcopyrite, in places inclosing it and in places being inclosed by it.

These two minerals were found in the deepest workings of the Afterthought mine at a depth of about 600 feet and in the deepest workings of the Bully Hill mine at 970 feet, as well as at higher levels. In places they are intergrown with and even entirely surrounded by barite, and there is no reason whatever to consider them as other than primary constituents of the ore. Both bornite and chalcocite, as well as chalcopyrite, however, are also formed in the upper portions of some of the ore bodies by the process of secondary enrichment, but almost all such occurrences can be readily distinguished from those in which the minerals ore of primary origin. ${ }^{1}$

The secondary zone was wonderfully productive of copper and silver at the Iron Mountain and Bully Hill mines, but at other mines it is either of little importance or practically absent. The secondary ores appear to have extended to no great depth and are now exhausted.2

\section{YERINGTON, NEVADA.}

The country at Yerington, Nev., is an area of schists and limestone with intrusive masses of granodiorite, or quartz monzonite, and related porphyries, which are overlain by a series of rhyolite flows and tuffs, bedded volcanic grits, andesite tuff, and andesite breccia, and an unconformably overlying flow of basalt. ${ }^{3}$

The copper deposits, according to Ransome, are (1) irregular bodies formed by metasomatic replacement of limestone and genetically associated with metamorphism of a kind usually attributed to the contact action of intrusive rock, (2) metasomatic vein deposits in altered limestone, and (3) metasomatic vein deposits in granodiorite.

To the first or contact-metamorphic class belong the deposits worked by the Bluestone, Mason Valley, and other mines. In the Bluestone mine the ore consists essentially of chalcopyrite dissemi-

1 Graton, L. C., op. cit., p. 105.

- Graton, L. C., Mineral Resources U. S. for 1907, pt. 1, U. S. Geol. Survey, 1908, p. 599.

- Ransome, F. L., The Yerington copper district, Nevada: Bull. U. S. Geol. Survey No. 380, 1909, p. 99.

Idem, p. 116. 
nated as grains and small irregular masses through limestone that has been altered to an aggregate consisting chiefly of a yellowishgray epidote with subordinate calcite and quartz. A little garnet is present. ${ }^{1}$ Zinc blende is not mentioned. In these deposits, as stated by Ransome-

Oxidation is not extensive and scarcely penetrates to the 100 -foot level, while chalcopyrite is present in the croppings. The products of oxidation are malachite (with possibly some brochantite and libethenite), azurite, cuprite, and chalcanthite. These are generally associated with sulphides, and there are no large masses of thoroughly oxidized ore. A little chalcocite occurs above the 100 -foot level, but there has been no important enrichment through the secondary formation of this mineral. It is evident that the ore body as a whole is too solid to have been penetrable to any considerable depth by oxidizing solutions and that erosion has kept pace with the process of weathering. ${ }^{2}$

The vein deposits in limestone are represented by the Ludwig vein, which is composed mainly of coarse crystalline calcite carrying some garnet with pyrite and chalcopyrite. Oxidation in this deposit has extended to a depth of about 500 feet and has produced ore of shipping grade. At the base of the oxidized zone there has been some chalcocite enrichment. ${ }^{3}$

The primary ore of the Mason Valley mine contains more pyrite with the chalcopyrite than that of the Bluestone mine and appears to be generally of lower grade. Oxidation, however, has penetrated deeper and has effected some local concentration down to the No. 3 tunnel, although some sulphides occur at the surface. On the No. 3 level there is a considerable body of rich ore consisting of impure earthy cuprite with much disseminated native copper. The shape and extent of this body, which contains up to 20 per cent of copper, have not been fully ascertained. Chalcucite in a soft, sooty condition occurs sparingly, but there has been no important enrichment through the formation of this sulphide. The minerals noted in the oxidized zone are malachite, azurite, cuprite, native copper, limonite, gypsum, and chalcanthite."

\section{VANCOUVER, BRITISH COLUMCBIA.}

The copper deposits on the west side of Vancouver Island are located near contacts of granite and calcareous sedimentary rocks and are composed of pyrite, bornite, garnet, and other minerals. The ore of the Monitor mine is a mixture of chalcopyrite, pyrrhotite, and coarse magnetite, filling interstices and holding unreplaced rock fragments. ${ }^{5}$

According to William M. Brewer, ${ }^{8}$ some of the deposits carry magnetite and gossan at the outcrop, and rich chalcopyrite ore was found in one deposit within 6 feet of the surface.

\footnotetext{
1 Ransome, F. L., The Yerington copper district, Nevada, Bull. U. S. Geol. Survey No. 380, 1909, p. 107. ${ }^{2}$ Idem, p. 108.

${ }^{8}$ Idem, p. 117.

$\checkmark$ Idem, p. 110.

- Weed, W. H., The copper mines of the world, New York, 1907, p. 222.

'Brewer, W. M., The copper deposits of Vancouver Island: Trans. Am. Inst. Min. Eng., vol. 29, 1900, pp. 183-488.
} 


\section{SNOWSTORM LODE, CGER D'ALENE DISTRICT, IDAHO.}

The Snowstorm lode, ${ }^{1} 3 \frac{1}{2}$ miles east-northeast of Mullan, Idaho, is a wide zone of impregnation in Revett quartzite (pre-Cambrian) and conforms with the bedding, which strikes N. $60^{\circ} \mathrm{W}$. and dips $65^{\circ}$ $\mathrm{SW}$. There is no pronounced fissuring along the lode, but microscopic study shows a network of fractures or invisible capillary openings which gave access to the ore-bearing solutions. The vein dips down the slope of the hill, and tunnel 3 is about 800 feet below the surface.

The ore is highly siliceous (over 90 per centt $\mathrm{SiO}_{2}$ ) and is in wide demand for use in ${ }_{0}$ converter linings. It carried (1904) about 4 per cent copper, 6 ounces silver, and 0.1 ounce gold.

In its unoxidized form the best ore consists of quartzite so crowded with little specks and small irregular bunches of bornite, chalcocite, and chalcopyrite as to be dark gray or nearly black. The microscope shows that the ore minerals to some extent fill irregular microscopic fissures but that for the most part they have replaced the interstitial sericite and siderite of the country quartzite.

Comparatively little of the ore, however, remains in its sulphide condition. Most of it has been oxidized to cuprite and malachite. There is no well-defined zone of oxidation, most of the sulphide ore occurring in No. 2 tunnel [about 460 feet below the outcrop measured on the dip of $65^{\circ}$ ] and some carbonate in No. 3 tunnel [about 1,200 feet below the outcrop measured on the dip of $\left.65^{\circ}\right] .{ }^{2}$

\section{COPPEROPOIIS, CALIFORNIA.}

The rocks in the vicinity of Copperopolis, Cal., are metamorphosed igneous and sedimentary rocks of the "Bedrock series" and include the Mariposa slate, meta-andesites, and other rocks, cut by gabbro, hornblende, granodiorite, and serpentine. ${ }^{3}$ The ore occurs as overlapping lenses, many arranged en échelon, each lens being composed of a complex series of bands or veinlets of chalcopyrite and pyrite deposited mainly parallel to the foliation of the schist. In age the ore, according to Reid, is earlier than the gold-bearing veins of the Mother Lode region. These veins are associated with the acidic intrusives of this part of the Sierra Nevada, which are distinctly later than the copper ore.

The surface zone of oxidized ore is very shallow; 30 feet or less, and a zone of secondary enrichment is entirely lacking. This is no doubt due to the fact that the intense lateral pressure in the rocks has prevented the formation of a vadose circulation. The actual surface is characterized by extensive gossan, in which occur seams of malachite, often very rich, coating the schist. A very small amount of azurite occurs, particularly toward the south. In the Empire ground, south to the concentrator, cuprite is found. Some very rich ore of this kind has been mined within a few feet of the concentrator, to the north. In a small incline shaft a few feet south

\footnotetext{
1 Ransome, F. L., and Calkins, F. C., The geology and ore deposits of the Cour d'Alene district, Idaho: Prof. Paper U. S. Geol. Survey No. 62, 1908, p. 151.

2 Idem, p. 152. The matter in brackets is mine.-W.H. E.

- Reid, J. A., The ore deposits of Copperopolis, Calaveras County, Cal.: Econ. Geology, vol. 2, 1907, pp. 880-417.
} 
of the Empire shaft cuprite appears as small flakes in the gliding planes of serpentine and talc. The ground to the south, from the Empire shaft to the gabbro boss, shows the largest amount of oxidized ore, due to the greater shattering of the rocks by the latest igneous intrusives.

Beneath this oxidized zone occur the original sulphides-chalcopyrite and pyrite in a gangue of country rock, the latter being usually chlorite schist. The richest ore is pure chalcopyrite; the copper content is lowered both by admixture of pyrite and of country rock. The presence of too much schist or other rock makes a low-grade concentrating ore; too much pyrite produces eventually waste material. Both the sulphide minerals, which occur relatively in all proportions, are found in thin veinlets or bands in the foliation planes of the serpentine and talc. ${ }^{1}$

\section{BOIEO, LOWER CAIIFORNIA.}

The Boleo mines, on the east coast of Lower California, are among the more important copper deposits in Mexico. According to Fuchs, ${ }^{2}$ the country is an arid dissected plateau composed of trachytic tuffs and conglomerate, probably Tertiary, which are cut by intrusive trachyte. The ore beds, which conform with the strata, are gently inclined to the sea. There are three beds, each of which is in general from 2 to 8 feet thick, and the three lodes are separated by a few feet of clayey tuffs and conglomerates. The ore beds are altered clayey tuffs and the ore is scattered through the clay in small fragments and nodules, hence the name. The minerals include cuprite, atacamite, azurite, malachite, chrysocolla, crednerite, and salt.

Stevens, ${ }^{3}$ who writes later than Fuchs, states that chalcocite and covellite predominate, although the lowest bed, which is partly below the water line, carries oxides and carbonates also. At the bottom of each bed is 6 to 8 inches of rich ore, which was once sorted to run about 20 per cent copper. De Launay supposed that the ores were formed by processes of sedimentation, the mineral waters issuing at the time the volcanic sedimentary rocks were formed, but Weed ${ }^{\mathrm{s}}$ suggests that they were formed by thermal waters after sedimentation.

\section{BRADEN COPPER MINES, CHILE.}

The mines of the Braden Copper Co. are in the O'Higgins province, Chile, in the Andes. The country rock is andesite surrounding a body of light-gray tuff, which is said to represent the crater of an ancient volcano. ${ }^{6}$ The diameter of the volcanic neck is about 4,000 feet and the periphery measures about $2 \frac{1}{2}$ miles. It is said to be of Tertiary age, presumably the later Tertiary.

The ore lodes are in and around the periphery of the crater, in andesite at its contact with tuff. The minerals are pyrite, magnetite,

1 Reid, J. A., The ore deposits of Copperopolis, Calaveras County, Cal.: Econ. Geology, vol. 2, 1907, p. 398.

2 Fuchs, Edmond, Note sur les gisements de cuivre du Boléo: Compt. rend. 14" sess. Assoc. franq̧. avancem. sci. (Grenoble, 1885), pt. 2, 1886, pp. 410-426.

8 Stevens, H. J., The copper handbook, vol. 9, 1909, p. 389.

-Quoted by Weed, W. H., The copper mines of the world, New York, 1907, pp. 245-240.

Idem, p. 246.

- Yeatman, Pope, The Braden copper mines: Min. and Sci. Press, vol. 103, 1911, pp. 769-77a. 
chalcopyrite, bornite, secondary chalcopyrite, zinc blende, and tetrahedrite(?). The nonmetallic minerals include tourmaline, quartz, ankerite, calcite, chlorite, sericite, mica, epidote, and zircon. In the zone of oxidation are limonite, cuprite, native copper, and carbonates and silicates of copper.

In one ore body, in the Fortuna mine, chalcocite occurs apparently only on their coatings on pyrite and chalcopyrite, increasing the grade of the ore only slightly. In the Teniente ore body the effects of sulphide enrichment appear to be somewhat greater. It is concluded, however, that the copper content is mainly in the primary minerals. Over $10,000,000$ tons of ore have been developed, the value being about 2.8 per cent copper.

\section{QUEEN OF BRONZE MINE, OREGON.}

The deposits of the Queen of Bronze mine, in southwestern Oregon, ${ }^{1}$ are irregular masses of ore in fractured and fissured portions of gabbro, peridotite, and serpentine.

The unoxidized ore is chalcopyrite, with which are associated pyrite, pyrrhotite, and subordinate amounts of quartz and calcite. In the low-grade ores pyrite and pyrrhotite are the most abundant minerals. In addition to the copper content, the ores carry some gold and silver.

The oxidized ores are malachite, azurite, cuprite, tenorite (?), and chrysocolla. Of these the black ores containing tenorite or chalcocite are more abundant. The average content in copper was more than 10 per cent. The lower limit of the oxidized ores is usually less than 90 feet from the surface, but some have been found at greater depths. In a small opening about 105 feet below the surface black oxide and small amounts of native copper were observed.

Although depths of about 300 feet have been reached in the workings, no important body of ore has been found below 125 feet.

\section{ENCAMPMENT DISTRICT, WYOMING.}

The copper deposits of the Encampment district, Wyoming, ${ }^{2}$ are in an area of pre-Cambrian metamorphosed igneous and sedimentary rocks, which are cut by pre-Cambrian gabbro, granite, and quartz diorite. The principal mines are the Doane and the Ferris-Haggarty, both of them in fractured quartzite. The primary copper ores are chalcopyrite and pyrrhotite. The secondary ores include azurite, malachite, chrysocolla, bornite, chalcocite, and covellite.

The country is about 10,000 feet above the sea; the climate is moist and ground water is near the surface. The lodes are tight and some mines are dry 450 feet below the surface. ${ }^{3} \quad$ At the Ferris-Haggarty mine there was a strong capping of spongy limonite containing no visible copper minerals. At the Doane mine green copper minerals

1 Diller, J. S., and Kay, G. F., Mineral resources of the Grants Pass quadrangle and bordering districts, Oregon: Bull. U. S. Geol. Survey No. 380, 1909, pp. 76-78.

2 Spencer, A. C., The copper deposits of the Encampment district, Wyoming: Prof. Paper U. S. Geol. Survey No. 25, 1904.

Idem, p. 4. 
mixed with the limonite were encountered at the surface and continued to a depth of 100 feet or more. ${ }^{1}$

The richest ores occur immediately below the gossan and are composed chiefly of secondary chalcocite. ${ }^{2}$ From the position of the stopes in several mine sections some chalcocite appears to extend downward probably, 200 feet or more below the top of the chalcocite zone. The secondary copper ores, according to Graton, ${ }^{3}$ carried good values in precious metal.

\section{DUCKTOWN, TENNESSEE.}

The Ducktown district, in Tennessee, occupies an intermontane basin in the heart of the southern Appalachian region, near the Georgia-North Carolina boundary. The ore deposits outcrop between 1,400 and 1,800 feet above the sea. The climate is moist. The prevailing rocks of the district are sandy schists and graywackes, with which are interbedded mica schists. The dominant series is the metamorphosed product of an association of sedimentary beds, including conglomerate, grits, sandstones, and shales. The beds grade into one another along the strike and across the bedding. They contain small bodies of pegmatites and peculiar masses and stringers of an actinolite-feldspar rock which has a composition near that of quartz diorite. The schists are cut by dikes of gabbro, which are not so highly metamorphosed by pressure as the sedimentary beds. The schistosity and the bedding of the sedimentary rocks strike nearly everywhere northeast, and the prevailing dip is southeast. These rocks have been folded into sharp folds, many of them isoclines. Many of the folds were broken along the crests of anticlines ${ }^{4}$ and pass into reverse strike faults that nearly everywhere dip southeast.

The ore bodies ${ }^{5}$ are replacements of limestone lenses which probably, though not certainly, were deposited at a single stratigraphic horizon. They range in width from a few feet to over 250 feet and have shapes that are characteristic of closely folded sedimentary beds. Anticlines and faulted anticlines, which are characteristic of this region, are shown in the ore zone. The ores themselves are somewhat metamorphosed by dynamic processes, and the gangue minerals are bent and twisted, but at most places they do not exhibit a well-defined

\footnotetext{
Spencer, A. C., The copper deposits of the Encampment district, Wyoming: Prof. Paper U. S. Geol. Survey No. 25, 1904, p. 45.

IIdem, p. 55.

8 Graton, L. C., Mineral Resources U. S. for 1906, U. S. Geol. Survey, 1907, p. 410.

- Keith, Arthur, Nantahala folio (No. 143), Geol. Atlas U. S., U. S. Geol. Survey, 1907.

- Safford, J. M., Geology of Tennessee, Nashville, 1869, pp. 469-482. Whitney, J. D., Remarks on * * * the east Tennessee copper mines: Am. Jour. Scl., 2d ser., vol. 20, 1855, pp. 53-57. Ansted, D. T., On the copper lodes of Ducktown, in east Tennessee: Quart. Jour. Geol. Soc., vol. 13, 1857, pp. 245-254. Heinrich, Carl, The Ducktown ore deposits: Trans. Am. Inst. Min. Eng., vol. 25, 1896, p. 173. Kemp, J. F., The deposits of copper ores at Ducktown, Tenn.: Trans. Am. Inst. Min. Eng., vol. 31, 1902, pp. 244-265. Weed, W. H., Types of copper deposits in the southern United States: Trans. Am. Inst. Min. Eng., vol. 30, 1901, p. 480. Emmons, W. H., and Laney, F. B., Preliminary report on the mineral deposits of Ducktown, Tenn.: Bull. U. S. Geol. Survey No. 470, 1911, pp. 151-172.
} 
schistosity. They were probably deposited after the rock that now incloses them and the limestone they replace had been subjected to considerable dynamic metamorphism. The outcrops are composed of iron oxides and quartz and contrast strongly with the country rock. All the lodes have a general northeast strike. South of the Culchote mine, which is near the center of the productive area, they strike more nearly north than east; north of the Culchote they strike more nearly east than north. In general the lodes dip southeast, but some dip northwest. The deepest development underground is about 800 feet below the surface.

The primary ore consists of pyrrhotite, pyrite, chalcopyrite, zinc blende, bornite, specularite, magnetite, actinolite, calcite, tremolite, quartz, pyroxene, garnet, zoisite, chlorite, micas, graphite, titanite, and feldspars. The minerals are generally intergrown and are of contemporaneous age. Essentially the same minerals are found in all the deposits, but they appear in varying proportions at different places in the lodes. Where its content of copper is above 1.5 per cent, or where its sulphur content is high, the material is ore, but where the proportion of actinolite and other lime silicates is greater and the sulphides are less abundant the material, though containing copper and other sulphides, is not workable.

The gossan extends from the surface to a maximum depth of 100 feet. It carries 40 to 50 per cent iron, generally less than 12 per cent silica and alumina, and 0.3 to 0.7 per cent copper. The minerals are hydrous iron oxides, quartz, jasper, and kaolin, with a little cuprite, native copper, and sulphur. Below the gossan iron ores is a zone of dark, rich copper ores, consisting of chalcocite and other copper minerals in a gangue of sulphates, quartz, and decomposed silicates. Under the higher portions of the outcrops of the lodes the top of this zone is about 100 feet below the surface, but the depth decreases down the slopes, and where the lodes are crossed by running streams the secondary copper ores are exposed at the surface. The upper limit of the chalcocite zone follows the level of ground water, which in turn follows the contour of the country but is less accentuated. ${ }^{1}$

The secondary minerals include argentite, azurite, bornite, chalcanthite, chalcedony, chalcocite, chalcopyrite, chrysocolla, covellite, cuprite, gypsum, iron sulphate, jasper, kaolin, limonite, malachite, marcasite, melaconite, native copper, sulphur, and talc. The copper content of much of this ore ranges from 20 to 30 per cent.

The secondary zone is less extensive vertically than most chalcocite zones elsewhere. The lodes are comparatively impervious to downward circulation, and it is believed that the reactions were brought nearly to completion before the descending oxidized solutions had moved downward great distances. 
In all the mines except the East Tennessee pyrrhotite is abundant, constituting more than half of the primary ore, and the vertical extent of the chalcocite zone is generally less than 10 feet. In the East Tennessee mine, in which pyrrhotite is much less abundant, the vertical extent of the chalcocite zone is at least 125 feet. The lodes are tight, and the downward circulation was probably slow before the mines were opened, but secondary chalcopyrite has been deposited below the chalcocite zone and probably extends 300 or 400 feet or more below the horizon of chalcocite.

\section{GOSSAN IEAD, VIRGINIA.}

The Gossan lead, in southwestern Virginia, is inclosed in highly metamorphosed crystalline schists. It strikes northeast, dips about $45^{\circ}$, and may be traced almost continuously for 18 miles. It consists of pyrrhotite, chalcopyrite, quartz, hornblende, mica, and other minerals.

Beneath the gossan there is usually found from a foot to 6 feet of the secondary copper ores, containing near the top more or less carbonate and oxide and very rarely a little native copper; farther down, on top of the unaltered sulphides, there is more or less soft black ore, the so-called "smut ore" of the miners, with secondary chalcopyrite. ${ }^{1}$

As stated by Weed, ${ }^{2}$ there has been some postmineral fracturing, which, presumably, would favor a downward circulation. The character of the enrichment is nevertheless closely similar to that in the pyrrhotite ores at Ducktown, Tenn. As stated by Watson, ${ }^{3}$ the weathering measured in 20 operations has extended to an average depth of 34 feet, ranging from 10 to 60 feet.

\section{STONE HILL, ALABAMA.}

At Stone Hill, Cleburne County, Ala., a deposit of pyrrhotite, with some chalcopyrite, is inclosed in gneiss and hornblendic and other schists. The ore body is said to be 24 feet wide and is traceable on the surface for 1,200 feet."

Below the shallow gossan are rich "black copper" ores of rather slight vertical extent, above the yellow sulphides.

\section{ELY, VERMONT.}

The copper deposits near Ely, Vt., are lenticular masses in mica schist. ${ }^{5}$ Some of the deposits have been worked to very great depths. The ore is composed of pyrrhotite, scattered grains and irregular

1 Weed, W. H., Copper deposits of the Appalachian States: Bull. U. S. Geol. Survey No. 455, 1911, p. 120.

Idem, p. 119.

3 Watson, T. L., Mineral resources of Virginia, Lynchburg, 1907, p. 421.

- Weed, W. H., The copper mines of the world, New York, 1907, p. 275.

S Smyth, H. L., and Smith, P. S., The copper deposits of Orange County, Vt.: Eng. and Min. Jour., vol. 77, 1904, pp. 677-678, Wẹed, W, H., Notes on the copper mines of Vermont: Bull. U. \$. Geol. Survey No. 225, 1904, p. 190, 
masses of chalcopyrite, and small amounts of pyrite and zinc blende. The gangue minerals consist of quartz, actinolite, garnet, and other metamorphic minerals. The main part of the ore body consists of very massive pyrrhotite, with small amounts of quartz and other minerals. ${ }^{1}$.

The country has been glaciated, and the tops of the deposits have very little gossan, the sulphide appearing at some places at the surface. The richer ores near the surface of these deposits were removed long ago, and published descriptions of the details of their occurrence are not available to me. Mr. J. W. Tyson, of the Tennessee Copper Co., at Ducktown, who was present when some of these deposits were opened, informs me that the richer black ores were found within 100 feet of the surface and laid like a floor over the lower-grade yellow sulphides. The relations, he states, were closely similar to those of the "black ores" at Ducktown.

\section{IA DICHA, MEXICO.}

The Dicha mine, Guerrero, Mexico, is 150 miles south of the City of Mexico, in a mountainous country about 50 miles east of Acapulco. According to Weed, ${ }^{2}$ the ore body, which occurs in micaceous schist, is parallel to the schistosity. It is proved for 7,700 feet along the strike and is from 12 to 88 feet wide. The ore consists of pyrrhotite with streaks, bunches, and specks of chalcopyrite scattered through it. It is said that the primary ore carries 5 per cent copper. Mr. Robert T. Hill ${ }^{3}$ informs me that the chalcocite zone is encountered at very shallow depths and is itself very thin, ranging in thickness from 6 inches to 6 feet. Its contact with pyrrhotite is sharp.

\section{SANTIAGO, CUBA.}

Copper lodes are found at several places along the south coast of Cuba east and west of Santiago. The most important deposits are those of the El Cobre mine. The ore minerals of the veins include pyrite, chalcopyrite, pyrrhotite, and quartz. ${ }^{4}$ Oxidized and chalcocite ores were found 50 or 60 feet below the outcrop. At greater depths pyritic ores in a siliceous gangue were found to carry 6 per cent copper without precious metals in paying quantity. The old workings, now caved, extended 1,300 feet below the surface. Copper is precipitated from mine waters on scrap iron.

\footnotetext{
1 Weed, W. H., op. cit., pp. 192-193.

2 Weed, W. H. (quoting R. T. Hill), The copper mines of the world, New York, 1907, p. 251.

${ }^{8}$ Correspondence.

4 Lawrence, B. B., Copper mining in Cuba: Min. and Sci. Press, vol. 93, 1906, p. 602. Weed, W. H., The copper mines of the world, New York, 1907, p. 20a
} 


\section{PINAR DEL RIO, CUBA.}

In the Province of Pinar del Rio, at the extreme west end of Cuba, gossans 150 to 200 feet wide are found. Below the gossans, at depths of 40 to 50 feet, are black copper ores. The sulphides include pyrrhotite, chalcopyrite, and chalcocite. ${ }^{1}$ The relations, according to Benjamin B. Lawrence, are similar in some respects to those seen at Ducktown, Tenn.

\section{BOUNDARY DISTRICT, BRITISH COLUMBIA.}

The Boundary district, British Columbia, ${ }^{2}$ lies between Columbia and Okanogan rivers, near the international boundary. The country is mountainous, forested, and about 5,000 feet above sea level. It is an area of sedimentary rocks, including limestones, argillites, and quartzite, with volcanic tuffs and ash beds, probably of Paleozoic age. Associated with these rocks are gneisses and schists, possibly Paleozoic also. The later rocks are porphyries, serpentines, and granodiorite. Various intrusions and flows of andesite, basalt, and other rocks are probably Tertiary. The deposits are perhaps related to intrusions of alkali syenite, which cuts most of the other rocks and is of Tertiary age.

The principal deposits are in limestone or greenstone, not far from intruding masses. The gangue minerals, according to Brock, include garnet, epidote, calcite, quartz, and actinolite. The principal sulphides are pyrite, chalcopyrite, and pyrrhotite. Magnetite is abundant in some deposits, and these contain less of the iron sulphides. Sphalerite, galena, and arsenopyrite are also present, and the ores contain appreciable quantities of gold and silver.

Oxidation extends only a few feet down into the copper ores, and locally the sulphide ore is polished and striated by ice.

The mother lode, according to Brock, is over 100 feet wide and at least 1,180 feet long and is developed to a depth of about 500 feet. Chalcocite is practically unknown in this deposit, the principal copper mineral being chalcopyrite. It is reported that the valuable minerals decrease in amount with increase of depth, but it is not certain that the richer deposits near the surface are due to chalcopyrite enrichment. A lens of the Knobhill-Ironsides deposit, according to Le Roy, ${ }^{3}$ is nearly half a mile long and has a maximum thickness of 125 feet and a known maximum width of 900 feet. Pay ore, according to Sterens, does not extend below 400 feet. Stevens says that the values

1 Lawrence, B. B., Copper mining in Cuba: Min. and Sci. Press, vol. 93, 1906, p. 602.

1 Brock, R. W., Preliminary report on the Boundary Creek district, British Columbia: Summ. Rept. Geol. Survey Canada for 1902, 1903, pp. 90-136. Le Roy, O. E., The geology and ore deposits of Phoenix, Boundary district, British Columbia: Mem. Geol. Survey Canada No. 21, 1912. Stevens, H. J., The copper handbook, vol. 9, 1909, pp. 206-207. Ledoux, A. R., The production of copper in the Boundary district, British Columbia: Jour. Canadian Min. Inst., vol. 5, 1902, pp. 171-177.

Le Roy, O. E., op. cit., p. 57.

$72293^{\circ}-$ Bull. 529-13 -14 
have declined from 1.7 per cent copper, 0.5 ounce silver, and $\$ 2$ gold per ton to about 40 per cent less in copper, 50 per cent in silver, and 60 per cent in gold. The ore reserves in 1910 were estimated by Otto Sussman at 5,595,000 tons.

At Copper Camp, near the head of Copper Creek, oxidized deposits of copper ores are found. In depth these give way to secondary sulphides, including chalcocite, below which are pyrite and chalcopyrite.

On the margins of the principal copper deposits are gold and silver veins. The minerals of these deposits include chalcocite, galena, zinc blende, pyrite, chalcopyrite, ruby silver, argentite, native silver, and gold. The chalcocite, rich silver minerals, and native silver and gold usually occur, it is said, in films around quartz crystals or in small crevices in quartz and calcite, indicating that they are products of enrichment.

\section{SAN JOSE, MEXICO.}

San Jose, Tamaulipas, Mexico, is 40 miles from Linares, on the Monterey \& Mexican Gulf Railway. The principal productive area is about 2,250 feet above sea level. The deposits are in an area of limestone and nepheline syenite, and the limestone is intruded by diorite and by porphyry. ${ }^{1}$

The limestone and the porphyry are cut by tinguaite and by basic dikes. Typical zones of heavy silicates with sulphide copper ores are developed near contacts of limestone and diorite porphyry. ${ }^{2}$ Magnetite is a contact mineral and is locally developed in large irregular masses. On the borders there are intermingled garnet and diopside, and throughout the magnetite are abundant veinlets of chalcopyrite and pyrite. One prominent outcrop gave the name "Piedra Imán," or lodestone, to the summit of Remedios Hill.

The most important copper mineral is chalcopyrite, which, according to Kemp, is almost invariably associated with pyrite. They appear not only as inclusions in the silicates but also as veinlets and as coatings in cavities. They cover in places the well-developed crystals of garnet so as to mold around them like a paste. The sulphides may themselves form large masses analogous to the magnetite and thus yield the best stopes of ore.

Ores including malachite, chrysocolla, and subordinate cuprite are found in the oxidized zone, especially along faults. I can find no mention of chalcocite in Kemp's descriptions.

1 Finlay, G. I., The geology of the San Jose district, Tamaulipas, Mexico: Annals New York Acad. Sci., vol. 14, 1904, pp. 247-295. Kemp, J. F., The copper Coposits at San Jose, Tamaulipas, Mexico: Trans. Am. Inst. Min. Eng., vol. 36, 1906, pp. 178-203.

'Kemp, J. F., op. cit., p. 189. 


\section{IA REFORMA MINE, CAMPO MORADO, MEXICO.}

The Reforma mine at Campo Morado, Guerrero, Mexico, is in an area of somewhat metamorphosed sedimentary rocks (probably Lower Cretaceous) that are cut by granodiorite, which locally is sheared. Later porphyry, probably monzonite porphyry, intrudes the older rock.

The ore bodies, as stated by $\mathrm{J} . \mathrm{W}$. Finch, ${ }^{1}$ are large and are extensively developed. The sulphide ore consists of practically solid masses of pyrite, with chalcopyrite, sphalerite, and galena and little or no quartz. It fills and replaces the beds, usually along the contacts with granodiorite, but is thought to be genetically related to the late intrusions. The Reforma body has an average width in six levels of about 100 feet and is continuous through the mountain. On the sixth level pyrite is developed for 2,000 feet on the strike between the oxidized zone at each end of the level.

The values are about equally distributed between gold, silver, and copper. The pyritic mass is compact and offers no large channels for water circulation. Oxidation is apparently thorough above the water level, but there has been very little reconcentration of copper in the oxidized zone. The copper-bearing waters appear to have drained laterally along the strike in the gossan to the surface or through the footwall slates. The zone of attack of oxidizing agents, as stated by Finch, appears to be measurable vertically in inches along practically all the profile of the pyrite, oxidation being complete as deep as it descends. A little covellite was found at the top of the pyrite in the Navajo workings, near by, but neither covellite nor chalcocite has been recognized in the Reforma. The sulphides appear to be impervious, and there is no evidence.whatever of sulphide enrichment.

\section{VELARDEÑA DISTRICT, MEIXICO.}

The Velardeña district, Durango, Mexico, ${ }^{2}$ near the Mexican International Railroad, between Torreon and Durango, is an area of folded Mesozoic (probably Cretaceous) limestone which is covered with andesitic tuffs and flows and cut by andesite intrusions. Dikes and irregular masses of alaskite and of trachytic alaskite and diorite intrude the older rocks. A siliceous phase of the diorite, probably quartz monzonite, is limited to a single intrusion near the Copper Queen mine. Contact metamorphism, with the development of heary silicates and metallic sulphides, has attended the intrusion of several of these rocks, and an interesting feature is the metamorphism and development of heary silicates in igneous as well as in calcareous

1 Finch, J. W., A geological journey in Guerrero: Min. and Sci. Press, vol. 101, 1910, p. 498.

¿Spurr, J. E., and Garrey, G. H., Ore deposits of the Velardeña district, Mexico: Econ. Geology, vol. 3, 1908 , pp. 688-725. 
sedimentary rocks. The ore deposits are of varied character and clearly indicate several epochs of ore deposition.

The deposits differ greatly in mineral composition, but most of them contain considerable zinc blende, zinc being about as abundant as copper. Some deposits contain also pyrrhotite.

The Copper Queen ore body, containing the principal copper ore of the region, consists of three main pipes or chimneys in metamorphic rock at the contact of the Copper Queen intrusion. The principal sulphides are slightly cupiferous pyrite, blende, and galena. The ores here mined are primary and there is no very great change of nature in depth. ${ }^{1}$

\section{SUDBURY, ONTARIO.}

The Sudbury nickel region, Ontario, ${ }^{2}$ is in a hilly, glaciated country of moderate relief. The climate is cold and moist. The nickeliferous rocks are included in an elliptical area some 40 miles long and 20 miles wide, the longer axis striking north of east. The central portion of the ellipse, occupied by Upper Huronian or post-Huronian rocks, has been weathered to a peneplain, which is surrounded by a hilly belt of eruptive rock. The oldest series in the region consists of Huronian graywacke, slate, quartzite, and conglomerate, which are intruded by acidic and basic eruptives. ${ }^{3}$ The Upper Huronian rocks (Animikie group) include conglomerate, tuffs, slates, and sandstones. Intruded between the Lower Huronian rocks or their igneous intrusives and the Upper Huronian sedimentary rocks is the great laccolithic mass, or sheet, probably of Keeweenawan age, which constitutes the Sudbury nickel-bearing eruptive. This great sheet dips toward its center, forming a canoe-shaped body which outcrops in a rudely elliptical belt having a nearly plane surface. . As a result of magmatic differentiation the lower portion of the eruptive is norite and the upper portion is micropegmatite, the two rocks grading into each other.

The ore deposits are (1) magmatic segregations, which occur between the norite and the underlying rocks, especially in depressions in the Huronian or in rocks intruded in the Huronian; (2) deposits of nearly related genesis in or near dikes of norite that extend outward from the lower contact of the main laccolithic body; and (3) deposits outside the laccolith, associated with norite intrusions, which possibly are connected with the principal body of the nickeliferous eruptive beneath the surface. The ore consists chiefly of pyrrhotite, which contains a small amount of pentlandite and

${ }^{1}$ Spurr, J. E., and Garrey, G. H., Ore deposits of the Velardeña district, Mexico: Econ. Geology, vol. 3,1908, p. 719 .

2 Barlow, A. E., Report on the origin, geological relations, and composition of the nickel and copper deposits of the Sudbury mining district, Ontario: Ann. Rept. Geol. Survey Canada, vol. 14, pt. H, 1904. Coleman, A. P., The Sudbury nickel field: Rept. Ontario Bur. Mines, vol. 14, pt. 3, 1905, p. 14.

3 Coleman, A. P., loc. cit. 
chalcopyrite. At many places it grades imperceptibly into pyrrhotitic norite. Fissures in the eruptive rock are filled with quartz and sulphides, and along the contact with the older rocks sulphides have been deposited by contact-metamorphic processes. Pyrite is intimately associated with pyrrhotite. ${ }^{1}$ Other minerals are magnetite, niccolite, cassiterite, gersdorffite, polydymite, danite, galena, native copper, sperrylite, and gold. The gangue includes the rockmaking minerals of norite, with some quartz, calcite, and other carbonates. Alteration products include limonite, chalcoeite, bornite, morenosite, annabergite, millerite, and probably several other species.

Rounded hills of gossan, ${ }^{2}$ indicating the presence of sulphide ore beneath, extend with almost unbroken continuity for miles along the contact of norite with underlying rocks. The offsets and isolated masses of norite with which some of the ore bodies are associated are generally made brownish by the decomposition of disseminated sulphides. Locally the covering of gossan is as much as 6 feet deep, although its ordinary depth is 2 or 3 feet, and it merges into sulphide ore beneath. Chalcocite ores are not conspicuously developed, although the presence of chalcocite in some deposits is noted by both Barlow and Coleman. In the Vermilion mine, where the gossan is deepest, chalcocite and copper carbonate are developed and there is a concentration of platinum or sperrylite in the gossan. The relations at the Copper Cliff mine of the Canadian Copper Co. suggest a probable chalcopyrite enrichment. In the earlier years of the development of this mine copper was greatly in excess of nickel, averaging 6.44 per cent, while nickel averaged only 2.38 per cent. Subsequently their proportions were reversed, and in $1904^{3}$ the matte from this deposit contained nearly twice as much nickel as copper. Of sulphide enrichment, C. W. Dickson " says that it is possible that the copper disseminated in the upper part of the ore bodies, now eroded, has been secondarily deposited by downwardmoving currents, but apparently not to any great extent, for the ground-water level is comparatively near the surface and there is little if any enriched sulphide.

When the thin surface covering is removed the pyrrhotite appears perfectly fresh and is without appreciable admixture of secondary minerals, such as are formed in the process of enrichment.

1 Barlow, A. E., op. cit., p. 97.

2Idem, p. 121.

8 Idem, p. 110.

- Dickson, C. W., The ore deposits of Sudbury, Ontario: Trans. Am. Inst. Min. Eng., vol. 34, 1901, pp. $61-62$ 


\section{PRINCE WILIIAM SOUND, ALASKA.}

The deposits of Prince William Sound, Alaska, are in graywacke and slates ${ }^{1}$ of two unconformable series, closely folded but not highly metamorphosed. These are cut by granitws, acidic dike rocks, and basic intrusive rocks. Basic flows altered to greenstone are commonly interstratified with the sedimentary rocks. The ores were deposited in zones of fracturing and shearing. The minerals in the ore bodies are chiefly pyrrhotite and chalcopyrite. With these in places are quartz, pyrite, and sphalerite, and at least one vein contains magnetite. As a rule the ore minerals are intimately intergrown and are thus apparently of contemporaneous origin. ${ }^{2}$

Possibly extensive surface alteration and sulphide enrichment took place before glaciation, and the remnants of the workable ores may be the roots of such enriched deposits. In the Bonanza mine, Latouche Island, chalcopyrite is less abundant in the lower level than it is nearer the surface. Since glaciation occurred there has been surface leaching and probably enrichment of the deposit, as is shown (1) by gossan, a few feet thick; (2) by a zone of black sulphides, a few inches thick, above the main ore; and (3) by waters that are carrying copper in solution and are in one locality depositing native copper and malachite. ${ }^{2}$

According to F. C. Lincoln ${ }^{3}$ the leachings from glacial bowlders have been precipitated in crevices as malachite.

\section{KASAAN PENINSULA, PRINCE OF WALES ISLAND, ALASKa.}

The copper deposits of Kasaan Peninsula are in an area of calcareous and other sedimentary rocks, which are interbedded with volcanic tuffs and cut by intruding masses of granodiorite and dikes of granite, syenite, and pegmatite. These intrusions were followed by the intrusion of dikes of felsite and subsequently of small dikes of diabase and basalt, which cut the ore bodies. The sedimentary rocks are greatly metamorphosed near their contact with the intruding rocks, where typical garnet-epidote-magnetite contact zones are developed. The deposits are in the main iron-copper sulphides, intergrown with the garnet gangue, and are generally near the contact of the sedimentary rocks with intrusive syenite. Most of the deposits are worked by open pits.

The ore is composed largely of magnetite, chalcopyrite, and pyrite associated with hornblende and calcite, all of which are included in a more or less banded garnetepidote gangue.

1 Grant, U. S., and Higgins, D. F., Reconnaissance of the geology and mineral resources of Prince William Sound, Alaska: Bull. U. S. Geol. Survey No. 443, 1910, p. 20.

2 Idem, p. 58.

${ }^{8}$ Lincoln, F. C., The Big Bonanza copper mine, Latouche Island, Alaska: Econ. Geology, vol. 4, 1909, p. 212.

- Wright, C. W., and Paige, Sidney, Copper deposits on Kasaan Peninsula, Prince of Wales Island: Bull. U. S. Geol. Survey No. 345, 1908, p.98. Wright, F. E. and C. W., The Ketchikan and Wrangell mining districts, Alaska: Bull. U. S. Geol. Survey No. 347, 1908. 
Surface oxidation has produced considerable limonite and some malachite and azurite; small particles of native copper also occur along slipping planes. These secondary minerals are relatively unimportant. ${ }^{1}$

It appears from descriptions of the various mines by Wright and Paige that pyrrhotite and zinc blende are lacking or very subordinate in these deposits. Pyrrhotite occurs in two of the prospects and in one of these zinc blende is present in considerable amount. Chalcocite enrichment is practically absent, though some was noted on the Goodro claims 200 feet below the surface. In the short time since the glacial epoch the pyrite and chalcopyrite have precipitated practically no secondary copper, though some oxidation has taken place and in a mine at Copper Mountain carbonates were noted 300 feet below the surface. ${ }^{2}$

BONANZA MINE, CHITINA COPPER BELT, ALASKA.

The Chitina copper belt, Alaska, ${ }^{3}$ is an area of greenstone, mainly diabase, which is overlain by Triassic limestones. Above the limestones are later sedimentary rocks. The various rocks are cut by porphyries, diorites, and gabbros. Andesite and other volcanic rocks, probably of Tertiary age, are also present. The country is rugged and the region of the deposits has been deeply eroded. The principal deposit is a rudely tabular mass of nearly pure chalcocite, which occurs in a fractured or fissured zone in the limestone just above the contact with greenstone. The very rich ore can be traced on the surface for about 250 feet. The deposit carries more than 60 per cent copper and 22 ounces silver to the ton and is estimated to contain over 100,000,000 pounds of copper. The thickness is indefinite, but the very rich ore, with its included limestone, as seen at the surface, has a width of approximately 25 feet, although the thickness of ore sufficiently rich to be mined may be greater. Below the deposit a little chalcocite and less bornite are found in some of the shearing planes in the greenstone but do not extend far into the greenstone. The quantity of each is small and the minerals are inconspicuous and might readily pass unobserved. A small amount of epidote is in places associated with the chalcocite. ${ }^{5}$

Though it extends to the very surface and accumulates in talus from the cliff, the chalcocite ore has no great vertical range. Owing to the rapid mechanical disintegration and the cold climate little or no gossan is developed. Open cavities in the fractured limestone have been filled with ice, and both the country rock and the talus on either

1 Wright, C. W., and Paige, Sidney, op. cit., p. 105.

2 Wright, C. W., Prospecting in the North (discussion): Min. Mag., vol. 4, 1911, p. 359.

8 Moffit, F. H., and Maddren, A. G., Mineral resources of the Kotsina-Chitina region, Alaska: Bull. U. S. Geol. Survey No. 374, 1909, p. 80.

'Graton, L. C., Mineral Resources U. S. for 1907, pt. 1, U. S. Geol. Survey, 1908, p. 592.

sMofft, F. H., and Maddren, A. G., op. cit., p. 83. 
side of this ridge are frozen all summer except for a few feet at the surface. No chalcopyrite and pyrite are recognized in the chalcocite ore. There is no evidence that either of these minerals was replaced, but immediately below the contact in the same shear zone bornite, chalcocite, and native copper are present in small amounts. ${ }^{1}$

It seems most unlikely that pyrite and chalcopyrite would be so completely replaced as to leave no vestige of the original mineral. Organic matter, especially if supplying hydrogen sulphide, could precipitate the copper as chalcocite, and the character and purity of the glance suggests a genesis somewhat similar to that of the copper glance deposits of Cashin, Colo., or the replacements of coaly material in many prospects in the West. ${ }^{2}$

In this connection the following statement of Moffit and Maddren ${ }^{3}$ is suggestive: The limestone "is found to have a blue color, which is indicative of considerable carbonaceous material in its composition." Although Moffit and Maddren only state alternate hypotheses as to the mode of deposition of the ore, in their discussion of the subject they seem clearly to favor the one which suggests the agency of cold waters. A possible source of the copper is the greenstone upon which the limestone rests. This formation is mainly diabase and at many places it carries a little copper.

\section{MOTHER LODE DISTRICT, CALIFORNIA.}

The Mother Lode district, California, as described by Ransome, ${ }^{4}$ is an area of crystalline schists and altered igneous rocks with intruded granodiorite and related rocks. The deposits are fissure veins, which generally trend northwestward and at many places parallel the schistosity of the country rock. I have no record that the ores contain manganese minerals. Placers are abundantly developed, and at many places rich ore is found at the very surface. According to Ransome, there is no evidence that the mines grow suddenly richer at any particular depth, nor is there any recognizable regular change in the value of pay shoots with depth below the zone of superficial weathering. Some of these deposits are very regular and uniform in value and have been developed to very great depths.

\section{NEVADA CITY AND GRASS VALIEY, CALIFORNIA.}

The area of Nevada City and Grass Valley, Cal., ${ }^{5}$ includes metamorphosed Carboniferous sedimentary rocks, compressed into isoclines, and associated igneous rocks less intensely metamorphosed. Above

\footnotetext{
1 Moffit, F. H., and Maddren, A. G., op. cit., p. 53.

- Lindgren, Waldemar, Copper, silver, lead, vanadium, and uranium ores in sandstone and shale: Econ. Geology, vol. 6, 1911, p. 568 .

${ }^{8}$ Moffit, F. H., and Maddren, A. G., op. cit., p. 25.

'Ransome, F. L., Mother Lode district folio (No. 63), Geol. Atlas U. S., U. S. Geol. Survey, 1900, p. 3.

B Lindgren, Waldemar, The gold-quartz veins of Nevada City and Grass Valley districts, Callfornia: Seventeenth Ann. Rept. U. S. Geol. Survey, pt. 2, 1896, pp. 1-262.
} 
these are slates with associated diabase and serpentine. These rocks are folded and metamorphosed but are not so intensely compressed as the Carboniferous. Intruded into these rocks are great bodies of granodiorite, probably of early Cretaceous age. The ore deposits are strong fissure veins, formed after the granodiorite intrusions. The minerals are quartz, chalcedony, magnetite, sericite, mariposite, pyrite, pyrrhotite, chalcopyrite, galena, blende, scheelite, arsenopyrite, tetrahedrite, stephanite, and cinnabar. Some earthy manganese ore occurs in small fissures in the granodiorite but not in connection with the quartz veins.

Near the surface ${ }^{1}$ the upper part of a vein is generally decomposed, forming a mass of limonite and quartz. The decomposition seldom extends more than 200 feet on the incline of a vein dipping $45^{\circ}$, or more than 150 feet below the surface. Fresh ore is found in places almost at the surface. The surface ore is generally richer than the fresh ore below, owing to the liberation of gold from the sulphides and the removal of substances other than gold. In this process silver also is partly removed. In some of the mines the lodes have been followed down the dip for 2,000 or even 3,000 feet. The unoxidized ore shows no gradual diminution of tenor in the pay shoots below the zone of surface decomposition. Within the same shoot there may be great variations of the tenor, but there is certainly no gradual decrease of it from the surface down. Important placer deposits were formed from these veins.

\section{OPHIR, CALIFORNIA.}

The rocks of the Ophir district, California, ${ }^{2}$ comprise amphibolite schists and massive amphibolites, with intrusions of granodiorite. These rocks are cut by quartz veins which fill coordinate fissures. The minerals are gold, electrum, some iron, copper and arsenical pyrites, with galena, zinc blende, tetrahedrite, and molybdenite. The gangue is mainly quartz, with a little calcite. The proportion of gold to silver varies by weight from $1: 1$ to $1: 10$, the gold predominating in value. Certain small ore shoots in veins in the amphibolite carry more than the usual tenor of gold, and the richest shoots are usually found where veins cross the belts rich in pyrite. According to Lindgren, such ore bodies may have been enriched by thermal waters concentrating gold from the pyrite in the iron belt. The common statement that the gold vein becomes barren as the depth from the surface increases is not justified, in his opinion, ${ }^{3}$ by the evidence afforded in the mines. The extensive development of placers, the value of

\footnotetext{
${ }^{1}$ Lindgren, Waldemar, The gold-quartz veins of Nevada City and Grass Valley districts, California: Seventeenth Ann. Rept. U. S. Geol. Survey, pt. 2, 1896, p. 182.

- 2 Lindgren, Waldemar, The gold-silver veins of Ophir, Cal.: Fourteenth Ann. Rept. U. 8. Geol. Survey, pt. 2, 1894, p. 252.

8Idem, p. 279.
} 
the ore near the surface, and the occurrence of valuable ore shoots just below the surface are opposed to the notion of extensive migration of gold in these deposits.

\section{SILVER PEAK, NEVADA.}

According to Spurr, ${ }^{1}$ the deposits of Silver Peak, Nev., are lenticular masses and fissure veins in Paleozoic sedimentary rocks. Genetically they are related very closely to granitic rocks which, as shown by Spurr, have alaskitic or pegmatitic phases. They are probably post-Jurassic and should be grouped with the California gold veins, with which geologically they have much in common. Concerning the Drinkwater and Crowning Glory deposits, which are the most important examples, Spurr says that no decided enrichment of the ores by oxidation can be established. The ores in the upper tunnel seem to have been locally richer than any found in the lower tunnel, but this difference has no evident relation to the surface and is probably original. The values occur as finely disseminated gold and auriferous sulphides. Placers are not mentioned.

\section{EDGEMONT, NEVADA.}

The gold deposits at Edgemont, Elko County, Nev., ${ }^{2}$ are in an area of quartzite, with intrusions of granodiorite. The deposits are fissure veins and their gold values are comparatively uniform. The ore consists of pyrite, galena, and arsenopyrite in a gangue of quartz. Copper carbonates and manganese minerals are rare or absent. The ore is stoped practically to the surface. There has probably been a slight amount of enrichment by removal of certain substances in the oxidized zone more rapidly than gold; there is no evidence that gold has been transferred below the water level by descending surface waters.

\section{DOUGLAS ISLAND, ALASKA.}

At the Treadwell mines, Douglas Island, Alaska, large dikes of albite diorite intrude greenstones and schist, and the shattered diorite has been extensively replaced by mineralizing solutions and cemented by low-grade gold ore. The minerals include quartz, albite, rutile, chlorite, epidote, calcite, siderite, pyrite, pyrrhotite, magnetite, chalcopyrite, and molybdenite. Manganese minerals are not reported.

The mines have been developed for 2,000 feet down the dip. According to Spencer, ${ }^{3}$ the ore shows no progressive change in appearance or value with increasing depth. In the lowest level it is quite as

${ }^{1}$ Spurr, J. E., Ore deposits of the Silver Peak quadrangle, Nevada: Prof. Paper U. S. Geol. Survey No. $55,1906$.

2 Emmons, W. H., A reconnaissance of some mining camps in Elko, Lander, and Eureka counties, Nev.: Bull. U. S. Geol. Survey No. 408, 1910, pp. 75-80.

8 Spencer, A. C., The Juneau gold belt, Alaska: Bull. U. S. Geol. Survey No. 287, 1906, pp. 32, 115. 
rich as in the upper workings, and it is evident that changes on the dip are no greater than along the strike. The best level of the Alaska Treadwell mine, according to Hershey, ${ }^{1}$ is 1,300 feet below sea level. Nothing in the character of the ore indicates any important concentration of values by oxidizing waters. The fact that extensive placers were not formed is not opposed to the view expressed by Spencer that the gold has not been transferred; the country has been recently glaciated and surface accumulations have been scattered. The gold accumulated at the apex since glacial time was, indeed, recovered by sluicing.

\section{BERNERS BAY REGION, ALASKA.}

The Berners Bay region lies along the Lynn Canal, 45 miles northwest of Juneau, Alaska. The country is an area of slates and graywackes of Jurassic or Cretaceous age and basic lavas and quartz diorites considerably altered by dynamic metamorphism. The Jualin diorite, intruding the sediments and lavas, is also later than the metamorphosed quartz diorite. ${ }^{2}$

The gold deposits, which are mainly in the Jualin diorite, are stockworks and fissure veins. The ores are composed of quartz, some calcite and pyrite, and minor amounts of chalcopyrite, galena, and sphalerite. The alteration of the wall rock was attended by the production of albite. Evidence of enrichment is lacking.

Knopf ${ }^{3}$ says:

Any enriched surface ores that may have existed within this region have been swept away by the powerful glacial erosion to which the region was subjected in the recent geologic past. The ores exposed at the surface are therefore of primary origin, modified to an unimportant extent by postglacial oxidation, and the outcrop of any ore deposit will furnish a true index of the value of the lode as a whole, depending on whether the distribution of values in the ore is or is not uniform.

\section{BLACK HILLS, SOUTH DAKOTA.}

The principal gold deposits of the Black Hills ${ }^{4}$ are in pre-Cambrian schists which, like the ore bodies, are cut by Tertiary intrusives. Since the Cambrian conglomerates contain placer gold, ${ }^{5}$ some of the ores must have been deposited in pre-Cambrian time. The most important deposits are comprised in the Homestake belt, about 3 miles long and 2,000 feet wide. The principal minerals are quartz,

1 Hershey, O. H., Geology at Treadwell mines: Min. and Sci. Press, vol. 102, 1911, pp. 296-300, 334-335; also in Bain, H. F. (ed.), Types of ore deposits, San Francisco, 1911, pp. 157-171.

2.Knopf, Adolph, Geology of the Berners Bay region, Alaska: Bull. U. S. Geol. Survey No. 446, 1911.

${ }^{8}$ Idem, p. 36.

4 Irving, J. D., Economic resources of the northern Black Hills: Prof. Paper U. S. Geol. Survey No. 26, 1904.

- Devereux, W. B., The occurrence of gold in the Potsdam formation, Black Hills, S. Dak.: Trans. Am. Inst. Min. Eng., vol. 10, 1882, p. 469. 
dolomite, calcite, pyrite, arsenopyrite, pyrrhotite, ${ }^{1}$ and gold, with which are associated the minerals of the schist-quartz, orthoclase, hornblende, biotite, garnet, tremolite, actinolite, titanite, and graphite. $^{2}$ The ores, though uniformly of low grade, are very profitable. Some of the ores at the surface were below the average tenor, while other surface ores were two or three times as rich as the average. The valuable minerals extend downward as far as exploration has gone and are fairly uniform to 1,000 feet or more below the surface. In general, according to S. F. Emmons, ${ }^{3}$ enrichment by surface leaching has had relatively small importance.

\section{HEDLEY DISTRICT, BRITISH COLOMBIA.}

The Hedley district, British Columbia, is in the valley of Similkameen River, some 30 miles north of the international boundary. The principal deposits are about 5,000 feet above sea level, and the whole district was covered with ice in the glacial epoch. The oldest rocks ${ }^{4}$ are of Paleozoic age, probably Carboniferous, and consist of limestones, quartzites, and argillites, interbedded with which are subaqueous volcanic tuffs and breccias. These are intruded by Mesozoic diorite and gabbro, by Tertiary granodiorite, and by dikes of aplite, rhyolite, and andesite.

According to Camsell, the ore bodies are contact-metamorphic deposits, which occur mainly in limestone near intrusive diorite or gabbro. Metamorphism has been greatest along contacts with gabbro. 5 The sulphides carry abundant arsenopyrite, with pyrrhotite, chalcopyrite, pyrite, and zinc blende; the gangue minerals include garnet, epidote, tremolite, diopside, and axinite, with some calcite and quartz. No manganese gangue mineral is mentioned and but small amounts are shown in analyses of the igneous rocks.

There is a thin capping of iron oxide, which extends in general some 8 or 10 feet below the surface. Leaching is deeper in ores composed chiefly of pyrrhotite than in ores composed mainly of arsenopyrite. There is no zone of enriched sulphides; but gold, which is the principal metal, has been transported downward to some extent, according to Camsell, resulting in an enrichment near the surface and to depths perhaps several hundred feet below. In ore bodies having a low dip there is a notable concentration of values along the gabbro footwall.

1 Sharwood, W. J., Analyses of some rocks and minerals from the Homestake mine, Lead, S. Dak.: Econ. Geology, vol. 6, 1911.

2 Irving, J. D., op. cit., p. 90.

8 Idem, p. 79.

1 Camsell, Charles, The geology and ore deposits of Hedley mining district, British Columbia: Mem. Geol. Survey Canada No. 2, 1910.

Idem, p. 25. 


\section{APPALACHIAN DISTRICTS.}

The gold deposits of the southern Appalachians are among the oldest gold deposits of the United States and were probably formed, ${ }^{1}$ in the main, 3 or 4 miles below the surface at the time of deposition. Many of them are in mica schist and other crystalline rocks, and some are closely associated with granitic intrusions. Some are cut by diabasic intrusives, presumably later than the ore. The deposits have yielded considerable placer and lode gold. The minerals, according to Graton, ${ }^{2}$ include quartz, sericite, biotite, fluorite, gold, pyrite, - galena, blende, pyrrhotite, chalcopyrite, and magnetite. Manganese minerals are not mentioned. In Becker's tabulation of the minerals of the gold mines of the southern Appalachians, compiled from all previous descriptions and including some mines not described by Graton, pyrolusite is mentioned as occurring in only three mines and rhodochrosite in one. ${ }^{3}$

Few of these deposits have been extensively explored in depth, and data respecting the vertical distribution of the gold are therefore meager. Many of them are profitable near the surface, partly by reason of the rotten condition of the rock, which renders it more easily worked, and partly because gold is accumulated or enriched by the removal of valueless material. In general there is, according to Graton, very little evidence for or against the theory of the migration of gold; but such migration, if it has taken place, has been extremely slow, for areas which have probably been exposed since Tertiary time show a marked concentration at and near the surface. Possibly some gold has been transferred to lower levels at the Haile mine, South Carolina, where, according to Graton, the limit of profitable mining is in general less than 200 feet below the limit of complete oxidation. In this zone scales of pyrite and free gold are found in joint cracks, indicating a relatively recent age. The deposits are cut by basic dikes. Prior to Graton's work many thought that the primary deposition of gold was genetically related to the dikes, ${ }^{4}$ for the workable ore appears to be limited to the area cut by them. If the basic dikes (like most basic rocks) carry manganese, it would appear probable that gold had been dissolved and the ore enriched near the dikes. Graton's tables show zinc blende in but one mine, the Kings Mountain mine, and pyrrhotite in but three others, the Haile, the Colossus, and the Asbury (which is not described). Both minerals are in the ore of the Dahlonega district described by Lindgren." All

1 Lindgren, Waldemar, The gold deposits of Dahlonega, Ga.: Bull. U. S. Geol. Survey No. 293, 1906, p. 124.

2 Graton, L. C., Reconnaissance of some gold and tin deposits of the southern Appalachians: Idem, p. 62.

8 Becker, G. F., Reconnaissance of the gold fields of the southern Appalachians: Sixteenth Ann. Rept. U. S. Geol. Survey, pt. 3, 1895, p. 277.

- Maclaren, J. M., Gold, its geological occurrence and geographical distribution, London, 1908, pp. 57, 59.

- Lindgren, Waldemar, op. cit., p. 119. 
these deposits had relatively rich ore near the surface and in none of them did it extend to great depths.

Certain ore deposits of Alabama recently described by McCaskey ${ }^{1}$ comprise fissure veins in granite and lenticular bodies in schists. The principal minerals are quartz, pyrite, and gold. Some garnet is found in the vein quartz at Pinetuckey. Weathering extends to water level, which lies 40 to 80 feet below the surface. The ores are oxidized above this level and are generally free milling, but below this level the ore is not profitably amalgamated so far as explored in depth. The ores are fairly regular in width and values, and no evidences of enrichment below the water level are recorded.

\section{ANNIE LAURIE MINE, UTAH.}

The Annie Laurie mine, ${ }^{2} 175$ miles south of Salt Lake, Utah, is in an area of dacite, rhyolite, and rhyolite tuff and probably belongs to the later Tertiary group. The vein is poorly exposed at the surface, being largely covered by morainal material. Lindgren says:

The quartz forms an almost continuous sheet along the vein, rarely less than 3 feet in thickness and often expanding to a width of 20 feet or more. As a rule, the walls are poorly defined and slickensides indicating motion are rare. In places it contains, parallel to the walls, streaks of iron oxides and black, sooty manganese ores.

The mine workings have not penetrated below the zone of oxidation, and neither the quartz nor the country rock seems to contain any unoxidized sulphides.

In the absence of extensive postmineral fracturing one would suppose that the conditions for migration of gold were not particularly favorable. Since the workings had not penetrated'sulphide ore at the date of Lindgren's report, direct evidence was lacking.

MANHATTAN, NEVADA.

The gold deposits at Manhattan, Nev., although inclosed in schists, are in an area of Tertiary volcanic activity and should be classed with the deposits formed in Tertiary time. Although the schists contain stringers of gold of uncertain genesis, the principal deposits are steeply dipping lodes of quartz and calcite, stained with iron and manganese oxides. Some placers are developed. Rich ore was found very near the surface, but it was richer a few feet below the outcrop than at the surface. Some fracturing has taken place since the deposits were formed. The gold of many of the pockets of rich ore is intimately associated with iron and manganese oxides. ${ }^{3}$ In view of the fact that the unaltered sulphides had not been encoun-

\footnotetext{
1 McCaskey, H. D., Notes on some gold deposits of Alabama: Bull U. S. Geol. Survey No. 340, 1908, p. 36.

2 Lindgren, Waldemar, The Annie Laurie mine, Piute County, Utah: Bull. U. S. Geol. Survey No. 285,1906, pp. $87-90$.

${ }^{3}$ Emmons, W. H., and Garrey, G. H., Notes on the Manhattan district: Bull. U. S. Geol. Survey No. 303,1907, pp. $87-90$.
} 
tered when the mines were visited, the character of the primary ore is unknown to me, nor is it certain that all the deposits have decreased in value below the oxidized zone.

\section{BULLFROG, NEVADA.}

In the Bullfrog district, Nevada, ${ }^{1}$ the principal deposits are fissure veins in rhyolite. The minerals include pyrite, quartz, and manganiferous calcite. Enough manganese is present in the calcite to stain much of the oxidized ore chocolate-brown or black. No placers are developed. The outcrops .were comparatively poor, but good ore was encountered within a few feet of the surface, and some of the deposits were worked by open cut. Some of the ore deposits decrease in value below the 400 -foot level, where ore carrying less than $\$ 5$ a ton is encountered. Since the ore above this level carried many times this value, it appears that there has been a secondary concentration by surface waters and that the rich ore is related to the present topographic surface.

In these ores, as in other manganiferous gold ores in calcite gangue, secondary deposition of gold has not been carried far below the surface.

\section{GOLD CIRCLE, NEVADA.}

The deposits of the Midas or Gold Circle district, Nevada, ${ }^{2}$ are in late Tertiary rhyolites. The lodes are replacement veins and sheeted zones and carry considerably more gold than silver by value. In the oxidized zone some of the ore is rich, but the sulphides are comparatively regular in value and give no evidence of extensive enrichment. Some oxidized ore shoots appear to have been increased in value by the removal of substances more soluble than gold. The minerals are chiefly quartz and pyrite. The oxidized zone contains seams of very rich gold ore, composed of manganese, limonite, kaolin, and soft hydrous silica.

\section{DELAMAR MINE, NEVADA.}

The Delamar mine, in southeast Nevada, is in quartzite which is cut by acidic porphyry dikes. The ore body, described by S. F. Emmons, ${ }^{3}$ is related to a strong zone of fracturing, which strikes with the quartzite but dips about $75^{\circ}$, or nearly at right angles to the dip of the quartzite. The ore is in shoots or zones of crushed quartzite. The chief ore body, which is, roughly speaking, a long and compara-

\footnotetext{
1 Ransome, F. L., Emmons, W. H., and Garrey, G. H., Geology and ore deposits of the Bullfrog district, Nevada: Bull. U. S. Geol. Survey No. 407, 1910.

2 Emmons, W H., A reconnaissance of some mining camps in Elko, Lander, and Eureka counties, Nev.: Bull. U. S. Geol. Survey No. 408, 1910, pp. 48-57

${ }^{3}$ Emmons, S. F., The Delamar and the Horn Silver mines: Trans. Am. Inst. Min. Eng., vol. 31, 1901, pp. $658-675$.
} 
tively thin, nearly upright cylinder, is divided into four parts by a dike of quartz porphyry and a more basic dike, which cross nearly at right angles in the ore body. The ore follows the line of intersection of the two dikes rather closely. The ore at the bottom of the mine consists of quartz and pyrite, which fill fractures in the altered quartzite. Where the dikes cross in the ore body the light-colored dike appears to be continuous, but notwithstanding this the line of the dark dike across the light one is generally marked by a slight stain of manganese dioxide, which, as stated by Emmons, is characteristic of the "black" dike and perhaps gives it that name.

Oxidation extends as far down as the tenth level. The ore that has been found below that level is too low in grade to pay for mining. The gold ore carries silver and some copper. The tenor in gold increased from the surface downward to about the seventh level, although the values were not evenly distributed. Some lots of ore ran as high as 30 ounces per ton, and the richer parts of the mine averaged from $\$ 30$ to $\$ 70$ per ton. At the tenth level they had decreased to $\$ 4$ or $\$ 5$ per ton.

\section{EXPOSED TREASURE MINE, CALIFORNIA.}

The Exposed Treasure mine, ${ }^{1}$ near Mohave, Cal., has produced considerable gold and silver. It is in an area of granitic rocks cut by quartz porphyry and capped by rhyolite. The lodes are probably Tertiary. The Exposed Treasure vein dips about $45^{\circ} \mathrm{E}$. and is a sheeted brecciated zone. Considerable fissuring has taken place since the ore was deposited.

The lodes are continuous and many of them are of great width, some being 40 feet and more from wall to wall, but the pay streaks, from 4 to 15 feet in width, lie in well-defined shoots and overlapping sheets or lenses. It is noteworthy that only those shoots or lenses which now reach the surface contained important quantities of calcite and manganese dioxide.

The oxidized ores contain much manganese dioxide, the concentrates carrying 12 per cent. In the altered oxidized ore are kernels of ore containing pyrite, chalcopyrite, galena, and sphalerite, and these are richer in the precious metals than the altered friable ore. As observed by De Kalb-

The altered ore bore manifest signs of extensive leaching, and where it had become almost completely decolorized by the removal of iron the precious-metal contents had nearly disappeared, and such ore never contained copper except in the form of chrysocolla.

The absence of sulphides in all the [oxidized] ores, except in the cherty skeletons and in the undecomposed kernels of hard ore, was very complete. The mill concentrates $\left(150\right.$ into 1) had an average composition of $\mathrm{SiO}_{2}, 30 ; \mathrm{FeO}, 37 ; * *$ and

1 De Kalb, Courtenay, Geology of the Exposed Treasure lode, Mojave, Cal.: Trans. Am. Inst. Min. Eng., vol. 38, 1908, pp. 310-319. 
$\mathrm{MnO}_{2}, 12$ per cent. These concentrates never contained more than 1.5 per cent of sulphur.

In the lower friable siliceous ores the ratio of gold to silver was as 1 to 12 , while in the upper mangano-calcitic ores the ratio was as 1 to 72 . Assays of gold scale and of coarse gold panned out from all parts of the mine showed a remarkably uniform alloy of 1 part of gold to 0.461 part of silver. The silver in the upper portion of the mine was present almost wholly in the form of silver chloride.

On the assumption, from the evidence, that the abundance of chlorides would prevent the leaching out of silver and its reconcentration below water level, and that the ferric and cupric sulphates would have abstracted large quantities of the gold, which would be redeposited lower down, together with the copper in the form of secondary enrichments, it was natural to predict an ore below permanent water rich in these metals and relatively lean in silver. It would be difficult to conceive a nicer justification of theory than that which was afforded when development at length extended below water level. The ore consisted of a hard bluish-gray mass of original chert-cemented breccia, recemented by quartz, with partial replacement of the granite and quartz porphyry by silica, heavily impregnated with sulphides, among which were considerable quantities of chalcopyrite, some bornite, and some covellite. The gold content of the ore had increased 150 per cent above the average in the friable siliceous ores on the upper levels, and the ratio of the gold to silver was as 1 to 2 .

\section{BODIE, CALIFORNIA.}

The deposits of Bodie, Cal., are east of the Sierra, near the State line. They are not of the California type but are associated with andesite and belong to the late Tertiary group so extensively developed in Nevada. R. P. McLaughlin ${ }^{1}$ has described the most important mines. The lodes are fissure veins in andesite. Nearly all strike northward and are approximately parallel. The ore carries about equal amounts of gold and silver. The deposits are developed extensively to a depth of 500 feet below the surface. One shaft is 1,000 feet, another 1,200 feet deep. Outcrops of encouraging value are rare: Almost without exception the veins have failed to carry pay ore beyond 500 feet below the surface; but above this depth occur large, rich ore bodies, which, according to McLaughlin, carry ore worth as much as $\$ 400$ a ton. Faulting and displacement are probably of later date than the period of vein formation. Some of the oxidized ore carries manganese dioxide. It is "loose and clayey in texture and carries some silver to the exclusion of gold."

\section{LITTLE BURRO MOUNTAINS, NEW MEXICO.}

The Little Burro Mountains, just north of Tyrone, N. Mex., consist of pre-Cambrian granitic rocks overlain by Cretaceous sediments and later eruptive rocks. These are partly buried by Tertiary (?) lavas and intruded by rhyolitic or trachytic stocks. ${ }^{2}$ Some gold viens in

\footnotetext{
' McLaughlin, R. P., Geology of the Bodie district, Cal.: Min. and Sci. Press, vol. 94, 1907, p. 796.

- Paige, Sidney, Metalliferous ore deposits near the Burro Mountains, Grant County, N. Mex.: Bull. U. S. Geol. Survey No. 470,1911, p. 132.
}

72293-Bull. 529-13-15 
this region carry abundant manganese dioxide and chlorides. The ore minerals include chalcopyrite, pyrite, sphalerite, and galene. ${ }^{1}$ Zinc blende is conspicuous, and the ores assay 10.2 per cent zinc.

\section{According to Paige ${ }^{1-}$}

The Wyman vein has been worked over a distance of about 500 feet and not below a depth of 110 feet. The richest returns came from the part above a depth of 40 feet. Silver chloride and gold furnished the values in these upper levels. Zinc and copper are reported to have increased as greater depth was attained and gold and silver to have fallen to $\$ 3$ to $\$ 5$ a ton. In the upper portion of the vein much of the ore is reported to have assayed $\$ 200$ to the ton.

\section{MARYSVILLE, MONTANA.}

Marysville, Mont., about 18 miles northwest of Helena, is in an area of pre-Cambrian sandstones, shales, and limestones that are intruded by quartz diorite and by later porphyry dikes. ${ }^{2}$ The deposits are mainly in fault fissures in sedimentary rocks. Placers are developed. The Drumlummon mine has been developed for about 3,000 feet horizontally and to a depth of 1,600 feet, but no ore was found below the 1,000-foot level.

According to Weed $^{3}-$

In general, it may be said that all the veins of the district carry rich ores in bonanzas and ore shoots within the first 200 feet from the surface, but that in depth the ores rapidly decrease in value until the vein is no longer workable. It may also be said that the ore shoots were well defined and the intervening vein matter barren and unworkable. The pitch of the ore shoots conforms to the usual habit, dipping to the right when looking down the dip of the vein. The ores consist of sulphides and sulphantimonides of silver, with gold aggregating 60 per cent of the total value. In the upper levels the ore is somewhat oxidized and in the ore shoots of the Drumlummon mine carried extremely high values.

Mr. Adolph Knopf 4 informs me that the gangue in depth is highly calcitic and that the rich ores of native gold that are found at and near the surface are associated with abundant manganese oxides.

\section{SUMOMIT DISTRICT, COLORADO.}

The Summit district is southwest of Alamosa, Colo., near the Rio Grande-Conejos county line. According to R. C. Hills, ${ }^{5}$ the metalbearing rocks are near the middle of the Tertiary eruptive series of south and southwest Colorado. The associated rocks are andesites, trachytes, rhyolites, and other eruptives; but, unlike the eruptives

\footnotetext{
I Paige, Sidney, Metalliferous ore deposits near the Burro Mountains, Grant County, N. Mex.: Bull U. S. Geol. Survey No. 470, 1911, p. 136.

${ }^{2}$ Barrell, Joseph, Geology 0. the Marysville mining district, Montana: Prof. Paper U. S. Geol. Survey No. 57, 1907 .

Weed, W. H., Gold mines of the Marysville district, Montana: Bull. U. S. Geol. Survey No. 213, 1903, p. 70.

1 Oral communication.

${ }^{6}$ Hills, R. C., Ore deposits of Summit district, Rio Grande County, Colo.: Proc. Colorado Sci. Soc., vol. 1, 1883, pp. 20-36.
} 
of most Tertiary districts in this province, these rocks appear to have been closely compressed and form a series which, as shown in Hills's sketches, is probably isoclinal. Some features of the ore deposits are puzzling, but, whatever their genesis, they illustrate very clearly the theory of enrichment-a fact which was fully recognized by Hills as long ago as 1883 .

The ore bodies, so far as exposed, are rudely tabular and approximately vertical. The ore is chiefly quartz and pyrite but contains some enargite, galena, sphalerite, and other minerals.

Although Hills mentions brown oxides at several places, he does not say that they are manganiferous. Raymond ${ }^{1}$ states that the oxides include those of purplish hue.

Placers appear to be of subordinate importance. The mineralized matter may be separated into three divisions-(1) the impoverished zone near the apex, (2) the zone of rich and partly oxidized ore, and (3) the zone of low-grade sulphides. The zone of impoverishment includes the outcrops of all but two of the lodes and it extends downward to a depth of 50 feet or more. The zone of incompletely oxidized ore extends to a depth varying from a few feet to 300 feet. In this zone the quartz is colored dark brown by oxides and the more highly auriferous material is characterized by an abundance of brown oxide. The gold in this ore carries only about 0.025 silver. According to Hills, all the bonanzas were confined to this zone. In some places gold appears in disseminated form, in innumerable small grains so aggregated as to resemble a continuous sheet of metal. Locally the grains unite and form flat nuggets 1 ounce or more in weight. According to Hills, the occurrence of this richer material is confined to the immediate vicinity of a central channel which has been filled with earthy matter, fragments of rock, and iron oxides. Some of the rich seams of gold powder have been introduced into fractures which cut barite. Below the rich and partly oxidized ore the primary sulphides appear to have been unworkable under conditions then existing. There is, however, in three mines a concentration of silver at greater depth than that of the gold bonanzas. Hills ascribes the two rich outcropping ore bodies, which are exceptional in this district, to intense kaolinization on either side of them, causing the country rock to be much more readily eroded than the extremely hard quartz. This consequently remained considerably above the general surface, forming a precipitous ridge that was, as he explains, protected from solution, which went on more vigorously below, in the places where snow and water accumulated.

${ }^{1}$ Raymond, R. W., Mines and mining west of the Rocky Mountains, vol. 10, 1875, p. 329. 


\section{BOHEMIA MINING DISTRICT, OREGON.}

The Bohemia mining district of Oregon is an area of andesitic lavas and tuffs, which are cut by dacite porphyry and probably by basalt. ${ }^{1}$ The deposits are fissure veins composed of sphalerite, pyrite, a little galena, and very little chalcopyrite, with a gangue of quartz, altered country rocks, and some calcite. According to MacDonald ${ }^{2}-$

Some of the veins were brecciated after they were filled, and as a result oxygenated surface waters were able to percolate downward along the fractured zone. The ores were thus oxidized and sulphides leached out to depths of 100 to 300 feet, the depth depending on the degree of brecciation and the rate of erosion. The gold occurred as threads and filaments included in the pyrite. The pyrite was leached away, leaving the relatively insoluble gold and some iron oxide occupying a part of the small cavity left in the vein material. This process brought about an association of free gold with iron-stained spongy quartz and enriched the ore by leaching out the valueless sulphides. It also rendered the ore soft and porous, so that it is much more cheaply mined and milled than the unaltered ore.

Small local enrichments of free gold occur at the junctions of fissures, pyrite being abundant at these junctions, as shown by the mass of iron oxide left. It is probable that the smaller particles of gold were dissolved from the upper parts of the vein * * * and were precipitated by the local masses of pyrite below.

Some secondary sulphides were observed, but these are of no commercial value. They consist of pyrite crystals deposited in cracks in primary pyrite and of very small masses of sphalerite and galena. Other secondary minerals noted were calcite and, rarely, cerusite.

\section{SAN JUAN REGION, COLORADO.}

The gold deposits of the San Juan region, Colorado, including those near Telluride, Silverton, and Ouray, are, as shown by Ransome, ${ }^{3}$ of varied character. They are mainly Tertiary, probably middle Tertiary, but have nevertheless undergone very extensive erosion. The region is moist, its altitude is 8,000 to 14,000 feet above sea level, and much of it has been glaciated. The prevailing rocks are volcanic tuffs, breccias, and flows and intrusive igneous rocks of intermediate or acidic composition.

In this elevated area the ground is frozen much of the year, and the rapid erosion is due largely to mechanical disintegration. Secular decay or oxidation of the ores, according to Ransome, is not as a rule very extensive and is at some places negligible. Purington has pointed out, however, that the outcrops of the San Juan lodes, are, in general, of lower grade than the ore a few feet below the surface, possibly by reason of the migration of gold in suspension. Many of

1 Diller, J. S., The Bohemia mining region of western Oregon: Twentieth Ann. Rept. U. S. Geol. Survey, pt. 3, 1900, pp. 7-64. MacDonald, D. F., Notes on the Bohemia mining district, Oreg.: Bull. U. S. Geol. Survey No. 380,1909 , p. 80.

2 MacDonald, D. F., op. cit., p. 82.

8 Ransome, F. L., A report on the economic geology of the Silverton quadrangle, Colorado: Bull. U.S. Geol. Survey No. 182, 1901. Purington, C. W., Preliminary report on the mining industries of the Telluride quadrangle, Colorado: Eighteenth Ann. Rept. U. S. Geol. Survey, pt. 3, 1898, p. 745. Purington, C. W., Woods, T. H., and Doveton, G. D., The Camp Bird mine, Ouray, Colo.: Trans. Am. Inst. Min. Eng., vol. 33,1903 , pp. 499-550. 
the lodes are tight and do not appear to offer favorable conditions for downward migration of waters. The country is well drained and chlorine is probably not abundant in the mine waters. The conditions for deep-seated enrichment are therefore not particularly favorable, although some concentration has taken place locally by the leaching and removal of the less valuable materials from the ore. The workable ore appears to be mainly of primary origin.

At some places the gangue includes manganiferous minerals. There is some evidence that gold was transported to a moderate extent. As Ransome points out, ${ }^{1}$ black oxide of manganese occurs (in 1901) in the deepest workings in the Tomboy and Camp Bird mines and usually indicates good ore. These little sheets of rich, dark manganiferous ore, which fill postmineral fractures, Ransome regards as later than the general mass of the ore. It is reasonable to suppose that they represent deposition from solutions which dissolved gold in the upper portion of the lode, where ferric salts prevail, and which, in the presence of manganese, were able to transport their load to greater depths, but which, coming into contact with pyrite, were ultimately reduced and forced to give up their gold when, through the oxidation of pyrite, ferrous sulphate had been formed.

In the Yankee Girl mine, between Silverton and Ouray, the ores down to about 200 feet from the surface were mainly silver and lead, galena and pyrite being the principal minerals. The ore below this zone is composed mainly of stromeyerite, bornite, chalcocite, and some gray copper and barite, yielding about 30 per cent of copper and little or no lead. In depths below 600 or 700 feet the ore in this and adjoining mines is said to have gradually turned into a low-grade pyritous ore, which was of too low grade to work at a profit, so that the mines were closed. The ores in the copper-bearing zone had been exceptionally rich, carrying several thousand ounces of silver to the ton in carload lots. ${ }^{2}$

\section{CRIPPLE CREEK, COLORADO.}

The gold deposits of Cripple Creek, Colo., are fissure veins and replacement deposits in volcanic breccia, in alkali-rich and other Tertiary intrusive rocks, and in granite. The fissures, according to Lindgren and Ransome, ${ }^{3}$ were formed at about the time of the intrusion of the associated basic dikes and represent a late phase of volcanic activity. The deposits are probably of middle or late Tertiary age and were formed relatively near the surface by hot ascending waters. Calaverite is the chief primary constituent;

1 Ransome, F. L., op. cit., p. 101.

2 Emmons, S. F., The secondary enrichment of ore deposits, in Pošepnł, Franz, The genesis of ore deposits, 1902, pp. 451-452.

Lindgren, Waldemar, and Ransome, F. L., Geology and gold deposits of the Cripple Creek district, Colorado: Prof. Paper U. S. Geol. Survey No. 54, 1906, pp. 167-168. 
native gold is rarely present in the unoxidized ores. Pyrite is widely distributed; tetrahedrite, stibnite, sphalerite, and molybdenite are sparingly present. The gangue is quartz, fluorite, adularia, carbonates (including rhodochrosite), some sulphates, and other minerals. Some of the deposits were workable at the surface, but the placers formed are relatively unimportant. Although rhodochrosite is subordinate in amount, the highly fractured country rock contains appreciable manganese ( $0.2 \pm$ per cent.). According to Lindgren and Ransome, the processes of oxidation were attended by the formation of kaolin, hydrous silica, and oxides of iron and manganese. Manganese oxides are commonly present in the oxidized zone ${ }^{1}$ and, according to Penrose, form nodules in the Pharmacist and Summit mines. They result from the alteration of rhodochrosite, manganiferous calcite, or other minerals and are generally distributed in the oxidized zone as stains in cracks and fissures. ${ }^{2}$ During oxidation manganese is greatly concentrated in the seams of the rock. In general, the lower part of the zone of oxidation is above water level and is usually less than 200 feet below the surface. In some places silver has been completely leached from the oxidized ores. Horn silver has not been noted.

Whether a slight enrichment of gold has taken place in the oxidized zone is not easy to demonstrate. Lindgren and Ransome are inclined to the belief that the oxidized zone as a whole is somewhat richer than the corresponding telluride zone. ${ }^{3}$ The trivial enrichment in this zone may have resulted from the removal of some constituents of the primary ore.

If gold was dissolved in the Cripple Creek deposits it was precipitated again at practically the same horizon, for in these deposits the zone in which solution takes place is rich. The ground is open, providing paths for downward-circulating waters, but although the ore-bearing complex is very pervious to water it is surrounded by impervious rocks. After the volcanic rocks had been drained in mining the flow of water was comparatively small. Lindgren and Ransome have compared the volcanic complex to a "sponge in a cup." As shown by them, the conditions were unfavorable for the circulation of atmospheric water-a fact which had an important bearing on their conclusion that the ores had been formed by magmatic waters. In the absence of a circulation the gold could not be transported. A check to this reasoning with respect to a downward circulation is the fact that in the porous, brecciated mass, filled with stagnant water, the oxidation extended downward to a depth generally less than 200 feet, and even in this zone residual sulphides are present. If the

\footnotetext{
1 Penrose, R. A. F., Mining geology of the Cripple Creek district, Colorado: Sixteenth Ann. Rept. U. S. Geol. Survey, pt. 2, 1895, p. 123.

2 Lindgren, Waldemar, and Ransome, F. L., op. cit., p. 123.

sIdem, p. 203.
} 
solutions did not carry oxygen downward it would be supposed that they could not carry gold; and even if the gold had been dissolved at the higher levels, in the absence of a circulation it could not descend. There is some evidence which may be interpreted as an indication that the gold migrated laterally, or possibly that it was precipitated essentially in place from cold solutions. Richard Pearce ${ }^{1}$ has recorded analyses of oxidized and unoxidized ore. The material for the analyses was taken from a section drawn clear across the two different portions of the specimen. 'The analyses show that the oxidized ore carries 14.58 ounces of gold per ton, or 2.34 ounces more gold than the unoxidized ore, and that all the silver has been leached out. In ore so rich such a concentration may result merely from leaching out of the substances other than gold; but, on the other hand, the analyses of the altered rock indicate that little leaching of the silicate minerals has taken place and that the oxidized portion was originally richer than the unoxidized, or else that some gold had been added. Since 0.27 per cent of manganese dioxide is present in the oxidized ore, while none is reparted in the unoxidized ore, it appears that manganese dioxide was added in the process of secondary alteration, and it is possible that the same solutions added gold and iron: J. W. Finch ${ }^{2}$ regards some of the gold as secondary.

If the gold was dissolved in the Cripple Creek "sponge," it may have been precipitated in the stagnant solutions where they were in contact with pyrite. In the absence of a downward circulation of water such lateral migration would be possible.

The results of oxidation processes are described by Lindgren and Ransome ${ }^{3}$ as follows:

Thorough oxidizing decomposition will destroy the original structure of this vein. In sheeted lodes with many small parallel fissures and joints the latter may become effaced and the lode appears as a homogeneous brown soft mass. In other cases a central seam may be retained and usually appears as a streak of soft, more or less impure kaolin; in other cases it may be filled by white compact alunite, more rarely by jasperoid or opaline silica. Crusts of comb quartz, if originally present, lie included in the clayey seams, but neither the original fluorite nor the carbonates are ordinarily preserved. Very rich oxidized ore sometimes fills the central cavities of the lode like a thick brown mud of limonite, kaolin, and quartz sand and easily flows out when the vein is opened.

It should not be inferred, however, that where channels are large and open the rich, gold-bearing brown mud is necessarily a deposit from solution. It may have been carried down in suspension; for similar rich mud, with 2 ounces of gold per ton, was found on the

1 Pearce, Richard, Further notes on Cripple Creek district: Proc. Colorado Sci. Soc., vol.4, 1896, pp.11-16.

2 Finch, J. W., The circulation of underground aqueous solutions and the deposition of lode ores: Proc. Colorado Sci. Soc., vol. 7, 1904, pp. 193-252.

'Lindgren, Waldemar, and Ransome, F. L., op. cit., p. 199. 
floor of the twelfth level of the Gold Coin mine, after it had been filled with water and allowed to stand.

It thus appears that the conditions at Cripple Creek, which are somewhat puzzling, may be rationally explained if it is noted that the downward migration of gold requires not only solution and precipitation but also circulation, and that the conditions for circulation here were peculiarly unfavorable. The facts show also that a relatively rapid circulation is required to carry dissolved gold far below the zone of mixed oxides and sulphides.

\section{GEORGETOWN QUADRANGLE, COLORADO.}

The auriferous deposits of the Georgetown quadrangle, Colorado, are mainly at Idaho Springs and in the Empire district, although some are developed near Georgetown, in the area of the silver-lead deposits. As shown by Spurr and Garrey, ${ }^{1}$ the gold lodes are probably of later age than the silver-lead deposits. They cut the crystalline schists and the Tertiary porphyries but are genetically related to alkali-rich intrusive rocks of middle or late Tertiary age. They carry pyrite, chalcopyrite, chalcocite, quartz, adularia, and gold and minor amounts of barite, fluorite, telluride, and other minerals. Carbonates of iron, magnesium, lime, and manganese occur but are relatively rare. The deposits generally contain some galena and sphalerite. In many of the mines the ore averages 1 to 2 ounces of gold and 20 to 40 ounces of silver per ton. The lodes are usually oxidized at the surface and from 15 to 70 feet downward. They have yielded some moderately productive placers. In several mines the oxidized ore is much richer than the average ore. Below the zone of oxidation secondary chalcopyrite and chalcocite prevail for several hundred feet from the surface but decrease at greater depth. There is an important enrichment of gold and silver, coincident with the occurrence of the copper minerals. As stated by Spurr and Garrey ${ }^{2}-$

In the mines mentioned a portion of the copper which has contributed to the enrichment of the original sulphides has been derived from the oxidized zone, but it seems unlikely that this has been the case with the gold and silver, which, like the enriched superficial portions of the argentiferous veins, must have been derived from the overlying portions of the lodes which are now eroded.

On the whole, the strongest evidence of the reworking of the ores by surface waters is afforded by markedly cupriferous ores. $* * *$ Apart from this, however, and from the probable partial concentration of galena near the surface in some mines, the evidence of rearrangement of the ores by descending waters is in general not nearly so great as in the Georgetown district, and such reworking has probably taken place to a considerably less extent.

\footnotetext{
${ }^{1}$ Spurr, J. E., and Garrey, G. H., Economic geology of the Georgetown quadrangle, Colorado: Prof. Faper U. S. Geol. Survey No 63, 1908, pp. 99-101.

'Idem, p. 149.
} 


\section{GOLDFIELD, NEVADA.}

The ledges of Goldfield are in middle or late Tertiary rocks and, according to Ransome, ${ }^{1}$ were probably deposited within 1,000 feet of the Tertiary surface. Ransome states convincingly the hypothesis that these deposits were formed by hot ascending solutions which mingled with descending sulphate water that contained oxygen derived from the air. Although the deposits are probably the most remarkable bonanzas of native gold ores carrying little silver which have yet been discovered, it does not appear that they have been very greatly enriched since they were deposited, for, as remarked by Ransome, it is difficult to harmonize the extent and intensity of alunitization in the gold ores with the hypothesis that the ores were formed by the oxidation and enrichment of lean deposits during erosion. The mine waters are rich in sulphates and, judging from the geographic position of the deposits, probably carry chlorides. Manganese dioxide is practically unknown in these ores, which in this respect differ from the ores at Tonapah and from a great many other Tertiary deposits of the Great Basin province. No workable placer deposits have been discovered; yet, notwithstanding the fact that several hundred feet of vein matter may have been removed from these deposits since they were formed, there is little reason to suppose that much gold has migrated into the existing bonanzas from above. The gold is very finely divided and could easily have been scattered if it had been eroded with the ledges. Analyses of deposits elsewhere that were formed close to the surface by ascending hot waters show that few of them carry much gold. The zone of maximum deposition is lower down, for as soon as the ascending hot waters are contaminated by ferrous sulphate from the surface the gold they contain must be precipitated.

The evidence offered at Goldfield is not out of harmony with the conclusion that in the absence of manganese gold is not readily transported in mine waters.

\section{PHIIIPSBURG, MONTANA.}

The Philipsburg quadrangle is an area of sedimentary rocks ranging in age from pre-Cambrian to late Cretaceous, with intrusions of granodiorite and related rocks, probably belonging to the same period of intrusion as that of the Butte quartz monzonite and other batholiths in Montana. The most important ore deposits in this quadrangle are those of the Granite-Bimetallic and Cable mines.

The Granite-Bimetallic mine ${ }^{2}$ is working a strong fissure vein in granodiorite, which carries chiefly silver but also an important

1 Ransome, F. L., The geology and ore deposits of Goldfield, Nev.: Prof. Paper U. S. Geol. Survey No. 66, 1909, p. 174 .

2 Emmons, W. H., and Calkins, F. C., Geology and ore deposits of the Philipsburg quidrangle, Montana: Prof. Paper U.S. Geol. Survey No. 78 (in press). 
amount of gold. There is conclusive paragenetic evidence of the enrichment of silver below the water level, and the rich silver ore carries also more gold than the low-grade silver ore in the bottom of the mine. The outcrop of this deposit carried some silver but very little gold, and after the discovery the location was allowed to lapse by reason of the small assay returns from the gossan. Richer ore with secondary cerargyrite, native silver, and ruby'silver in cracks across the older sulphides appeared in considerable amount 200 to 400 feet below the surface and extended to depths of 800 or 900 feet. The shoot of high-grade ore, which extended for about a mile along the strike of the deposit, followed, in a broad way, the present rugged surface. The gangue is rich in manganese. No pyrrhotite was noted, but zinc blende is abundant at several places in the primary ore below the richer sulphides. Some migration of gold has undoubtedly taken place. No associated placers have been developed.

At the Cable mine ${ }^{1}$ the deposits are included in a long, thin block of limestone, in contact on either side with quartz monzonite. The principal minerals are calcite, quartz, pyrrhotite, pyrite, magnetite, and chalcopyrite, with chlorite, muscovite, and other silicates. At one or two places small traces of manganese dioxide have been noted in the oxidized ore, but it is very much less abundant than in the deposits of the Granite-Bimetallic type. This deposit yielded important placers. Good ore was found at or very near the surface and, according to the best obtainable data, the tenor increased somewhat for a short distance below the surface. Some concentration has taken place by the removal of calcite and other valueless material more rapidly than gold, but there is no evidence of enrichment in gold below the water table. The conditions indicate that the gold has not been extensively transported since the deposit was formed.

\section{NEIHART, MONTANA.}

The Neihart district, Montana, ${ }^{2}$ is a region of Archean granite and pre-Cambrian quartzite with intrusive diorite and porphyry. The deposits are silver-bearing fissure veins, which in depth carry considerable sphalerite, pyrite, and galena. Superficial alteration is not marked, and there are no great zones of carbonates and oxidized ore. The Broadwater vein is partly oxidized to a depth of 170 feet and in pipes and fissures to even greater depths. Below the oxidized ore were large bodies of secondary silver sulphides, consisting of polybasite, pyrargyrite, pearceite, and "sooty sulphide ores," much

\footnotetext{
1 Emmons, W. H., and Calkins, F. C., Geology and ore deposits of the Philipsburg quadrangle, Mont.: Prof. Paper U. S. Geol. Survey No. 78 (in press).

2 Weed, W. H., Geology of the Little Belt Mountains, Montans: Twentleth Ann. Rept. U. S. Geol. Survey, pt. 3, 1900, p. 271.
} 
of this ore running 200 to 1,000 ounces per ton. The rich silver minerals occur in cracks in the primary ore or coat fragments of that ore. Manganese oxides abound.

The zones of impoverishment, of enrichment, and of unaltered primary sulphides recognized in the case of the copper veins are clearly present here, though the uppermost is of limited extent, and the zones are not so sharply or definitely separated from one another as they are in copper deposits, owing to the later fissuring of the vein filling allowing the secondary enrichment to be mixed with the unaltered sulphides. * * * In the Neihart ores polybasite seems to show an alteration to pyrargyrite and pyrite, and the former in turn changes to native silver in the upper zone. ${ }^{1}$

\section{TINTIC DISTRICT, UTAH.}

The Tintic district ${ }^{2}$ is in central Utah, in a mountainous area that rises some 8,000 feet above the sea and nearly 4,000 feet above the plains. The temperature is moderate, the climate is dry, and most of the streams that drain the area disappear in the loose material of the desert. The area is occupied by a thick series of Paleozoic quartzites, slates, limestones, and sandstones, which are overlain by Tertiary rhyolite and andesite and intruded by monzonite and basalt. The andesite flows are intruded by great masses of monzonite and by basalt dikes, and an andesite equivalent to the monzonite caps the rhyolite. ${ }^{3}$ These rocks are folded and extensively fractured and faulted. The late history of the region may be briefly stated as follows: ${ }^{4}$

1. Elevation of the region, with folding of the Paleozoic sedimentary rocks.

2. Erosion, which began with the Mesozoic uplift and continued into the Tertiary, producing a surface with greater relief than that of to-day.

3. Tertiary volcanic activity, the earlier rhyolitic lava filling deep canyons, on the slopes of which talus was cemented by the lava and the later andesite lava flows, largely rejuvenating the deeply eroded mountain range.

4. Fissuring and ore deposition in the more compact igneous and sedimentary rocks.

5. Erosion, by which great masses of igneous rock have been removed, with only slight changes in the topography of the limestone ridges, which had been buried by the lavas.

The ore deposits are (1) large fractured zones in sedimentary rocks, chiefly in the limestone; (2) fissure veins in igneous rocks; and (3) contact-metamorphic deposits in sedimentary rocks near intrusive igneous rocks, mainly in the limestone near monzonite. ${ }^{5}$

\footnotetext{
1 Weed, W. H., The enrichment of gold and silver veins: Trans. Am. Inst. Min. Eng., vol. 30, 1901, p. 446.

2 Tower, G. W., Jr., and Smith, G. O., Geology and mining industry of the Tintic district, Utah: Nineteenth Ann. Rept. U. S. Geol. Survey, pt. 3, 1899, pp. 603-767.

8 Idem, p. 657.

1 Smith, G. O., written communication.

-Tower, G. W., jr., and Smith, G. O., op. cit., p. 722.
} 
In igneous rocks the water level is encountered 200 to 700 feet below the surface; above this the ore is almost completely oxidized. In limestone the water level is much deeper and oxidized ore extends 1,800 feet or even 2,000 feet $^{1}$ below. the surface.

The primary ore minerals of the deposits include pyrite, galena, enargite, chalcopyrite, and tennantite. Sphalerite is rare in this district, ${ }^{2}$ and pyrrhotite is not mentioned. The gangue includes quartz, barite, carbonates, chalcedony, and gypsum. Oxidation products include limonite, hematite, anglesite, cerusite, minium, melaconite (?), native sulphur, jarosite, copper carbonates, cuprite, native copper, and a large number of rare arsenic compounds which have resulted from the decomposition of enargite. Argentite, stephanite, and native silver are somewhat rare. Cerargyrite is more abundant. Chalcocite and bornite become increasingly abundant in the lower parts of the oxidized zone. Some quartz is clearly secondary. ${ }^{3}$

The metals, named in the order of their importance up to 1898, are silver, lead, gold, and copper. With increasing depth silver and lead have decreased relatively and copper has become more abundant, especially in the Centennial Eureka mine. In 1909 the yield of copper was $6,000,000$ pounds, the district ranking in copper production the thirteenth in the United States. According to Graton, ${ }^{4}$ secondary sulphide deposition seems to have played but little part in the distribution of values.

A remarkable feature of the district is the great depth at which the oxidized ores are found. They are deeper, indeed, than the submerged oxidized ore at Bisbee, Ariz., where the deep secondary zone is related to a pre-Comanche erosion surface rather than to the present one. At Tintic, however, the ores are probably early Miocene. ${ }^{5}$ Since they were formed, great masses of igneous rocks, according to Smith, ${ }^{6}$ have been removed by erosion.

\section{GEORGETOWN, COLORADO (SILVER DEPOSITS).}

The Georgetown district, Colorado, is a rugged area of gneisses and schists, which are cut by Tertiary intrusives of varied composition. Several thousand feet of overlying rocks, according to Spurr, Garrey, and Ball, ${ }^{7}$ have been eroded since the veins were formed. Some of

1 Lindgren, Waldemar, oral communication.

:Tower, G. W., jr., and Smith, G. O., op. cit., pp. 686, 703.

8 Idem, p. 693.

4 Graton, L. C., Mineral Resources U. S. for 1906, U. S. Geol. Survey, 1907, p. 407; idem for 1907, pt. 1, U. S. Geol. Survey, 1908, p. 618.

s Smith, G. O., written communication.

-Smith, G. O., The mineral crest, or the hydrostatic level attained by the ore-depositing solutions in certain mining districts of the Great Salt Lake basin (discussion of W. P. Jenney's paper): Trans. Am. Inst. Min. Eng., vol. 33, 1903, pp. 1060-1062.

${ }^{7}$ Spurr, J. E., Garrey, G. H., and Ball, S. H., Economic geology of the Georgetown quadrangle, Colorado: Prof. Paper U. S. Geol. Survey No. 63, 1908, p. 145. 
the valuable minerals of the eroded portions have been redeposited in the portions remaining.

The zone of complete oxidation is 5 feet to 40 feet deep. In the silver-lead deposits the minerals on the lower levels are chiefly zinc blende and galena, with pyrite, chalcopyrite, and a little silver and gold. Rich soft sulphides are found, especially along cracks and watercourses, and are of secondary origin, having evidently been concentrated from the leaner ore by descending waters. They occur down to considerable depths from the surface but in decreasing quantity. The older and typically more massive ores in which they have formed contain usually very much less silver and also less gold. For example, secondary sulphides which contain 200 to 300 ounces of silver have been formed by this concentration process from primary ore which carries only 20 to 30 ounces.

Below the zone where soft secondary sulphides occur and irregularly overlapping the lower portion of this zone the rich ores contain polybasite, argentiferous tetrahedrite, and ruby silver, better crystallized and more massive than the pulverulent sulphides but also subsequent in origin to the massive galena-blende ore. These richer ores diminish in quantity as depth increases, though gradually and irregularly, so that the lower portion of the veins contains relatively less silver and lead. The best ore in most veins has been found in the uppermost 500 feet, although good ore extends locally down to 700 or 800 feet, and in the Colorado Central and to a minor extent in other veins down to a thousand feet or more. ${ }^{1}$

\section{BRECKENRIDGE, COLORADO.}

The fundamental rocks in the Breckenridge region, Colorado, as stated by Ransome, ${ }^{2}$ are granites, pegmatites, gneisses, and schists of pre-Cambrian age. The oldest sedimentary rocks, which rest directly on the pre-Cambrian, are red sandstones and shales, supposed to be of Triassic or of Permian age. Apparently conformable above them is the Dakota quartzite with some gray shale, which is overlain by a thick formation of Upper Cretaceous shales. The sediments and the pre-Cambrian rocks are intruded by monzonitic porphyries, which occur mainly as sills.

The primary deposits, according to Ransome, include veins of a zinc-lead-silver-gold series, stockworks and veins of a gold-silver-lead series, and the gold veins of Farncomb Hill. The placers of the district have been important producers of gold.

The Wellington veins afford the chief examples of the zinc-leadsilver-gold series, the filling of which consists mainly of sulphides, quartz in notable quantity being absent from most of them. In the Wellington mine the principal constituents of the ore are galena, sphalerite, and pyrite in various proportions. Even along the out-

1 Spurr, J. E., Garrey, G. H., and Ball, S. H., Economic geology of the Georgetown quadrangle, Colorado: Prof. Paper U. S. Geol. Survey No. 63, 1908, p. 144.

${ }^{2}$ Ransome, F. L., Geology and ore deposits of the Breckenridge district, Colorado: Prof. Paper U. s.

Geol. Survey No. 75, 1911, pp. 25-26. 
crops of the veins of the Wellington group most of the deposits carry galena in the claylike product resulting from thorough oxidation, and the change to essentially sulphide ore generally takes place at depths of less than 300 feet. The depth of the oxidized zone, however, varies, being greatest in general near the crest of the ridge in which the ore bodies occur and least along the lower slopes.

The normal sequence from the surface down appears to be (1) a soft, heavy yellowish claylike ore consisting largely of earthy cerusite and containing residual nodules of galena; (2) a lead-silver ore in which the galena is only in part oxidized, while the pyrite has been for the most part changed to limonite and the sphalerite altered to smithsonite and limonite, with removal of much of the zinc in solution; and finally (3) a lead-silver-zinc ore in which galena predominates and in which the early stages of oxidation are indicated by the formation of a little spongy smithsonite, or "dry bone," as the miners call it, at the expense of the zinc blende. ${ }^{1}$

A notable feature of the oxidized ores is their general high content of lead and silver as compared with the sulphides beneath. In some mines this difference was so great that their owners after extracting ore profitably to the base of the oxidized zone found the sulphides of so low a grade that they abandoned work. Here and there the oxidized ores also show a noteworthy concentration of gold even where the sulphide ores below contain only negligible quantities of that metal. Thus in the Helen mine, on the south side of French Gulch, some gold ore was found near the surface, although the latest and deepest workings have exposed nothing but a little sphaleritic zinc ore. In the Juventa mine, which produced some good oxidized ore to a depth of 200 feet and was then abandoned, wire gold is said to have been found.

It is believed that a large proportion of the galena is the result of downward concentration by atmospheric water, which, after percolating with comparative rapidity through the oxidized zone to the local ground-water level, thence moved more slowly down through the sulphides, emerging finally along the bottoms of the main valleys. Although some sphalerite is younger than other sphalerite, it is not surely a deposit of sulphate waters. Iron is deposited as an impure siderite in veinlets traversing the sulphide ores or as the lining of vugs in these ores. Additional iron issues in springs after performing its work of enrichment. Silver, according to Ransome, generally keeps close to the lead, and gold appears to accumulate in the zone of oxidation rather than at greater depths. In general, profitable operations did not extend below 300 or 350 feet in depth.

The Farncomb Hill veins immediately below the zone of oxidation consist of pyrite, chalcopyrite, sphalerite, galena, calcite, and gold. Some wire gold has been found in the unoxidized vein material but

1Ransome, F. L., Geology and ore deposits of the Breckenridge district, Colorado: Prof. Paper U.S. Geol. Survey No. 75,1911, p. 134. 
not far below the zone of general weathering, and the principal concentration of the native metal is connected with oxidation.

\section{Says Ransome: ${ }^{1}$}

Two intimately related processes appear to have been effective in enriching these veins. These, in the order of their action at one place, were (1) enrichment by solutions depositing calcite, galena, gold, and perhaps sphalerite below the zone of oxidation and (2) enrichment in the zone of oxidation by solution and redeposition of the gold.

It is clear that during the weathering of these veins the gold was acted on by some very efficient solvent, for otherwise it would be impossible to account for the large crystalline masses of gold characteristic of the hill. These could not have been deposited in the veins as part of their original fillings, for they are limited to the oxidized zone, and the once very productive placers below the hill show that this zone can not coincide with originally rich upper portions of the veins. Evidently the original tops of the veins have been eroded away and their contained gold in part has been strewn along the ravines and down the main valleys and in part has seeped down in solution along the fissures and been deposited in segregated masses. Active as śolution must have been, erosion apparently was overtaking it; at least the richness of the placers proves that the gold was not carried down and redeposited fast enough to escape the forces of mechanical disintegration.

Ransome states that a manganiferous carbonate occurs in the Wire Patch mine of Farncomb Hill, and sphalerite from the Silver vein showed some manganese, but some oxidized material from the Reveille showed none. It is not known whether the mine water carried appreciable chloride, but the experiments of Brokaw (p. 126) indicate that under some conditions a faint trace of chlorine is effective in the solution of gold. In connection with the abrupt impoverishment in depth, attention should be called also to the mineral association of these ores and to experiments previously cited showing the rapidity with which acid solutions are reduced by sphalerite and auriferous chloride solutions are neutralized by calcite. With both calcite and sphalerite the conditions for rapid precipitation of gold are very favorable.

\section{CREEDE, COLORADO.}

The deposits of Creede, Colo., ${ }^{2}$ are strong fissure veins in rhyolites and rhyolite breccias. One of them extends for nearly 2 miles along the strike and is developed from 1,000 to 1,400 feet below the surface. The rocks show great postmineral fracturing. The primary deposits consist of pyrite, zinc blende, galena, and other minerals in a gangue of manganiferous amethystine quartz with barite, chlorite, and some adularia. The most valuable deposits of silver, the most important metal in this district, were found 200 to 700 feet below the surface, but wire silver was mined at depths below

1 Ransome, F. L., Geology and ore deposits of the Breckenridge district, Colorado: Prof, Paper U. S. Geol. Survey No. 75, 1911, p. 169.

2 Emmons, W. H., and Larsen, E. S., A preliminary report on the geology and ore deposits of Creede Colo.: Bull. U. 8. Geol. Survey No. 530, 1913, pp, 42-65. 
1,000 feet. Some of the richest silver ore is evidently secondary and consists of red jasper with abundant native silver.

Stringers of black manganese oxide cutting unoxidized sulphide ore extend downward to depths of nearly 1,000 feet. In the Happy Thought mine, on the Amethyst vein, between levels 6 and 7, a body of partly oxidized ore composed of galena, zinc blende, copper carbonates, cerusite, and anglesite carries a conspicuous amount of manganese dioxide, which coats the copper sulphides and occurs in fractures cutting the partially oxidized ores. A considerable body of this ore yielded $\$ 20$ a ton in gold, which indicates notable enrichment, since the average content of gold in the mine is about $\$ 2$ a ton.

\section{RICO, COLORADO.}

The rocks of Rico, Colo., ${ }^{1}$ include Paleozoic limestones, sandstones, and shales, which are cut by dikes and laccolithic sheets of monzonite porphyry. The ore deposits include fissure veins and ribbon-like masses, which make out in limestone from the fissure veins where the latter cross the contact of limestone with overlying shale. In the lower levels of the mines, some 200 feet below the "contacts," the ore is mainly quartz, pyrite, and chalcopyrite. In raising on the veins rhodochrosite, galena, sphalerite, and tetrahedrite become prominent. Upward, toward the "contact," the proportion of metallic minerals steadily increases, and the ore becomes much richer in gold and silver. Irregular nuggets and sheets of argentite, polybasite, and stephanite are found. Occasionally pyrargyrite, proustite, and native silver appear. Rhodochrosite, on the other hand, is almost never found in the zone immediately below the shale, although it is abundant in the vein lower down.

\section{IAKE CITY, COLORADO.}

The silver-lead deposits of Lake City, ${ }^{2}$ in southwestern Colorado, are in an area of Tertiary flows and tuffs of the Silverton volcanic series, which consists of andesites, rhyolites, latites, and basalts. These are cut by intrusions of rhyolite and quartz latite and by quartz monzonite porphyries.

The deposits are narrow fissure veins and some fill conjugate fis- sures. Their vertical range, according to Irving and Bancroft, is over 5,000 feet, and in their lower levels the primary minerals are chiefly quartz, galena, zinc blende, and pyrite. The ores formed at shallower depths include also tetrahedrite, rhodochrosite, barite, and jasperoid. The mineralization was probably effected by solutions

1 Ransome, F. L., The ore deposits of the Rico Mountains, Colo.: Twenty-second Ann. Rept. U. S. Geol. Survey, pt. 2, 1901, pp. 229-398. Farish, J. B., The ore deposits of Newman Hill: Proc. Colorado Sci. Soc., vol. 4, 1892, pp. 151-164.

2 Irving, J. D., and Bancroft, Howland, Geology and ore deposits near Lake City, Colo.: Bull. U. 8. Geol. Survey No. 478, 1911. 
connected genetically with the quartz monzonite intrusion or with some closely related deeper rock.

Many of the lodes are greatly fractured, and the conditions in this rugged country are favorable to deep circulation. Erosion is rapid, however, and the oxidized zone is not deep, extending generally not more than 100 or 200 feet below the surface. This zone contains iron oxides and sulphates, copper carbonates, and considerable anglesite, with some native copper and silver. Cerusite is not abundant.

The secondary silver minerals are chiefly pyrargyrite and galena but include some chalcocite and possibly proustite. Native gold, though not common in the oxidized ore, is present in the upper part of the zone of sulphide enrichment. Of the total production of all metals having a value above $\$ 7,000,000$, about one-sixth is gold. The table showing the metal production of the district indicates a fairly constant proportion in the annual production of gold and silver. The abundance of sphalerite in the primary ore would seem to favor relatively rapid precipitation of the metals by descending solutions. Some of the secondary ore shoots, however, have a wide vertical range, but such a distribution of the richer ore has been greatly favored by the very rugged topography. At the Moro mine the secondary sulphides are found nearly 500 feet vertically below the surface, but the slope is between $30^{\circ}$ and $40^{\circ}$ and the circulation is presumably vigorous. The reactions precipitating the metals seem to have been relatively rapid. As stated by Irving and Bancroft, ${ }^{1}$ zinc blende has very generally exerted an extensive effect in reprecipitating the downward-moving sulphates in the form of secondary sulphides.

\section{ASPEN, COLORADO.}

The Aspen district, Colorado, ${ }^{2}$ is an area of granite overlain by Paleozoic limestones, sandstones, and shales, which are intruded by dikes and sills of diorite porphyry and quartz porphyry. Structurally the district is a fault mosaic of folded beds and the principal ore deposits are replacements of limestones in and along fault fissures. The primary ore deposition was effected by ascending magmatic waters and took place in a relatively brief period, but according to Spurr $^{3}$ it had three successive stages-(1) barite veins, (2) silver sulphides, sulphantimonites, and sulpharsenites, (3) galena and blende-each stage being preceded by slight fracturing of the rocks. The maximum deposition was below shale beds.

Near the surface the ores occur as oxides, sulphates, and carbonates, mixed with sulphides, from which they are evidently

${ }^{1}$ Irving, J. D., and Bancroft, Howland, Geology and ore deposits near Lake City. Colo.: Bull. U. S. Geol. Survey No. 478,1911 , p. 64 .

2 Spurr, J. E., Geology of the Aspen mining district, Colorado: Mon. U. S. Geol. Survey, vol. 31, 1898.

8 Spurr, J. E., Ore deposition at Aspen, Colorado: Econ. Geology, vol. 4, 1909, p. 303.

$72293^{\circ}-$ Bull. $529-13-16$ 
derived. The principal ore in these upper zones consists of earthy carbonates and sulphates, chiefly of lead (cerusite and anglesite). Among the oxides hematite and limonite are very common, and the red oxides of copper and lead (cuprite and minium) occur in blotches in the oxidized ores, usually indicating the presence of silver. With increase in distance from the surface the oxides, sulphates, and carbonates disappear and give place to pure sulphides. Argentiferous galena and blende are abundant in the deeper ore and other sulphides are of less frequent occurrence. Pyrite and chalcopyrite, with occasional bornite, are aiso found. Tetrahedrite and tennantite are common and contain a large proportion of silver sulphide. The gangue is quartz and barite.

In the Mollie Gibson and Smuggler mines there is much polybasite, which generally occurs in flesh-colored barite, the color being due to a small amount of iron oxide. Along watercourses the polybasite is reduced to native silver, so that the ore consists of pink and gray barite bound together by irregular wires and masses of silver. As this process is attended by some loss of bulk, the ore also becomes much jointed and loses cohesion.

Spurr states that native silver is abundant to depths of at least 900 feet in deposits where the water level stood about 300 feet. Generally the native silver is found near silver sulphides and in fractures that are later than primary mineralization. Nearly all the larger bodies of native silver are on the side of the vein which is formed by shale and some of them are wholly within the shale wall.

\section{IEADVILIE, COLORADO.}

Leadville, Colo., ${ }^{1}$ is in an area of Paleozoic limestones, quartzites, and shales that are intruded by dikes and sills of acidic porphyries. Normal faulting has taken place on an extensive scale. The climate is moist, the altitude high. The most important deposits are found in Carboniferous limestone at or near its contact with an overlying porphyry, which is generally the "White porphyry." Thus the ores constitute a sort of sheet, the upper surface of which, being formed by the base of the porphyry sheet, is comparatively regular, while the lower surface is ill defined and irregular, there being a gradual transition from ore to limestone, the ore extending to varying depths below the surface, occupying in places the entire thickness of the Leadville ("Blue") limestone. Other deposits include, however, steeply dipping veins, some of them in fault fissures, and irregular masses or sheets in limestone near the "Gray" or other porphyries.

The ore that is most abundant and that is economically by far the most important is argentiferous galena and its secondary products,

1 Emmons, S. F., Geology and mining industry of Lead ville, Colo.: Mon. U. S. Geol. Survey, vol. 12, 1886. Emmons, S. F., and Irving, J. D., The Downtown district of Leadville, Colo:: Bull, U. S. Geol. Survey No. 320,1907 . 
cerusite, or carbonate of lead, and cerargyrite, or chloride of silver. Lead is also found as anglesite and pyromorphite and occasionally as oxide in the form of litharge or, more rarely, of minium. Silver occurs frequently as chloroiodide and very rarely in the native state. The gangue minerals include quartz, chert, barite, and clay, the clay being frequently charged with iron and manganese oxides or with sulphates.

A common alteration product of mixed pyrite and galena, a product that is associated in considerable quantity with the ore bodies, is "basic ferric sulphate," an ocherous substance of somewhat uniform appearance but of varying composition, mainly a mixture of jarosite, or yellow vitriol, and hydrated basic ferric sulphate, with more or less anglesite and pyromorphite.

Gold occurs in the native state, generally in extremely small flakes or leaflets. It is also said to have been found in the filiform state in galena.

Accessory minerals are zinc blende, calamine, arsenic (probably as sulphide), antimony (probably as sulphide), wulfenite, copper (carbonate and silicate), and bismuth sulphide.

In depth the ores consist of pyrite, sphalerite, and galena in fairly equal amounts, with some chalcopyrite and other minerals.

Nodules of galena surrounded by lead carbonates are locally numerous in the oxidized zone. Several of these nodules have t:een assayed, and the sulphide has been found to carry about six times as much silver as the surrounding carbonate shell. ${ }^{1}$

Emmons ${ }^{2}$ states that gold exists in the limestone ores only in traces. In certain veins of sulphide ores below the porphyry contacts, according to G. Montague Butler, ${ }^{3}$ some small masses of sphaleritic manganiferous ores are very rich in gold. A picked sample assayed 8 ounces per ton. Silver is found in the oxidized ores mainly as chloride. It is a generalization of the miners of the region, according to Emmons, 4 that rich silver-chloride ores are likely to accompany manganese. As suggested by him and also on a previous page of this paper (p. 120), it is possible that the agency of manganese in the generation of free chlorine is important in connection with the precipitation of silver chloride under some conditions.

In general, silver values diminish with depth. The upper contact bodies as a whole were richest in silver; the "second contact" bodies were slightly lower in tenor; and at lower horizons the ore is of distinctly low grade. ${ }^{5}$

1 Ricketts, L. D., The ores of Leadville, Princeton, 1883, p. 37.

2 Emmons, S. F., op. cit., p. 545 .

8 Butler, G. M., Some recent developments at Leadville: Econ. Geology, vol. 7, 1912, p. 318 ,

Emmons, S. F., op. cit., p. 562.

Emmons, S. F., and Irving, J. D., op. cit., p. 34. 
Very recently large bodies of iron-stained smithsonite have been found in the oxidized zones below lead-carbonate ores. Some of these were formerly supposed to be iron-stained limestone. A. A. Blow ${ }^{1}$ maintained that sphalerite is deposited by downward-moving waters just in advance of oxidation, and in this S. F. Emmons ${ }^{2}$ appears to concur. Some small veinlets of galena are found also in sulphide ore just below the oxidized zone.

Of considerable interest are some small fractures in the quartzite at a lower horizon, which, as Mr. Emmons informed me, very commonly carry small amounts of high-grade manganiferous gold ore. This ore he regarded as a deposit from descending waters.

EUREKA, NEVADA.

The Eureka district, ${ }^{3}$ in eastern Nevada, is an area of Paleozoic quartzites, limestones, and shales, which were intruded, probably in late Mesozoic time, by granite, granite porphyry, and quartz porphyry. Subsequently, probably in the Tertiary period, the sedimentary rocks were intruded by great igneous bodies of andesitic composition and covered in places by rhyolite and basalt. The beds are thrown into open folds and the dominant structure is a fault mosaic, the principal faults being of the normal type.

The ores occur in sedimentary rocks belonging to the Cambrian, Silurian, and Devonian periods. Through a section involving 17,000 feet of deformed strata they have been deposited in sufficiently large bodies to encourage mining exploration.

According to Curtis, ${ }^{4}$ the ore bodies are chiefly replacements of fractured limestones and include lodes, stocks, and bedding-plane deposits. The elevation of the region is from 6,000 to 7,500 feet above the sea, but neighboring peaks are higher. The climate is arid and the water level deep. On a section by Curtis through the Jackson, Eureka Consolidated, and Richmond shafts ${ }^{5}$ the water level is shown at a depth of 500 feet in the Jackson and from 1,000 to 1,200 feet in the Richmond shaft.

The larger ore bodies, according to Curtis, are capped by caves or are in some way connected with caves or fissures, developed by solution, and the fall of rock into the openings has caused further fissuring. Since this action took place the ore has in many places been redistributed by the flow of underground waters. The ore above the water level is composed principally of the minerals galena,

\footnotetext{
1 Blow, A. A., The geology and ore deposits of Iron Hill, Leadville, Colo.: Trans. Am. Inst. Min. Eng., vol. 18, 1890, p. 172.

2 Emmons, S. F., The secondary enrichment of ore deposits, in Pošepny, Franz, The genesis of ore deposits, 1902 , p. 440 .

${ }^{8}$ Hague, Arnold, Geology of the Eureka district, Nevada: Mon. U. S. Geol. Survey, vol. 20, 1892.

${ }^{1}$ Curtis, J. S., Silver-lead deposits of Eureka, Nev.: Mon. U. S. Geol.'Survey, vol. 7, 1884.

- Idem, Pl. III.
} 
anglesite, cerusite, mimetite, and wulfenite, with very little quartz and calcite, the gangue being for the most part hydrated oxide of iron. The ore carries also considerable gold and silver and some zinc, which occurs probably as carbonate and silicate. The ore below the water level is composed chiefly of pyrite, arsenopyrite, galena, zinc blende, and a few other sulphides, as well as silver and gold. According to Curtis the oxidized ore grades into the sulphide ore. At some places altered ore is found below the water level, and Curtis supposed that the water level was recently elevated. The development of mimetite, a chloro-arsenate of lead, as stalactites in the oxidized zone, is of interest. Zinc blende is found to some extent in upper parts of the mines, according to Curtis, and is of common occurrence in the lower workings in connection with pyrite and galena. The deposits had produced over $\$ 60,000,000$ in silver and gold and 225,000 tons of lead in 1882. More recently enormous bodies of low-grade ferruginous gold ore have been mined in the shattered and altered limestones that surround the old silver stopes.

PIOCHE, NEVADA.

The deposits of Pioche, Nev., ${ }^{1}$ are in a faulted area of quartzites, limestones, and shales which are cut by an acidic porphyry intrusive. The most important deposits, some of which have been very productive, are near the intrusives. They fill fissure veins in the quartzite and limestone and the ores are more abundantly developed in the quartzite. They were stoped at the surface and averaged about $\$ 150$ a ton. Ores consisting of silver chloride and sulphide and lead carbonate extended to water level, where the oxidized ore gave place to sulphides and large amounts of zinc also entered. At this depth, according to Pack, ${ }^{2}$ the vein was generally strong and persistent, but no valuable deposits were in sight when the property was abandoned, even though prospecting had been very extensive.

In recent years some other large productive deposits have been developed. Of these I have no exact knowledge.

\section{TONOPAH, NEVADA.}

The deposits at Tonopah, Nev., are silver-gold replacement veins in andesite. They are of middle or late Tertiary age but possibly somewhat older than the Comstock lode. Placers are not developed. The primary ore, according to Spurr, ${ }^{3}$ is composed of quartz, adularia, sericite, and carbonates of lime, magnesia, iron, and manganese, with argentite, stephanite, polybasite, chalcopyrite, pyrite, galena,

1 Pack, F. J., Geology of Pioche, Nev., and vicinity: School of Mines Quart., vol. 27, 1906, pp. 285-312, $365-386$.

I Idem, p. 372.

Spurr, J. E., Geology of the Tonopah mining district, Nevada: Prof. Paper U. S. Geol. Survey No. 42, 1905, p. 90. 
silver selenide, and gold in an undetermined form. Pyrrhotite is not listed. According to Spurr, a little zinc sulphide is present, but Burgess ${ }^{1}$ does not list sphalerite as a vein mineral.

The zone of oxidation extends to greater depth in the more highly fractured places, and for this reason the brittle and more broken lodes are more deeply oxidized than the wall rock. The Mizpah vein is for the most part oxidized to a depth of 700 feet. Standing ground water is lacking. The oxidized ore contains limonite and manganese dioxide, with plentiful horn silver and some bromides and iodides of silver. The so-called oxidized ore from the outcrop down is, according to Spurr, a mixture of original sulphides (and selenides), together with secondary sulphides, chlorides, and oxides. At a depth of 500 feet (in the Montana Tonopah mine) good crystals of argentite, polybasite, and chalcopyrite have been formed freely in cracks and druses of the sulphide ore. These minerals are later than the massive ore, but it can not be shown that they were not deposited upon it by ascending waters. The deposit of dark ruby silver (pyrargyrite) is different, however, for it is formed in cracks in the oxidized ore, and some argentite fringes minute particles of horn silver as if secondary to it. The evidence, therefore, as stated by Spurr, favors the view that these secondary sulphides in the oxidized zone originated from descending surface waters, and probably part of the sulphides in druses in the sulphide ore have a similar origin.

The waters that descend through the oxidized zone carry sulphates and chlorides, and "wad" is plentiful; but judging from the fairly constant proportion of gold to silver (about 1 to 100 by weight) there has been little selective migration of gold and silver during oxidation, although the vein has been enriched to some degree by downward penetration of minerals leached from the outcrop as it was eroded. The rich ore shoots, though partly oxidized, seem to be in the main original without thorough rearrangement. According to Spurr, this may be ascribed in part to the relatively scanty supply of water in this arid region.

\section{COMSTOCK IODE, NEVADA.}

The Comstock lode ${ }^{2}$ is a broad fault zone in late Tertiary rocks. The ore shoots occur here and there in this zone, which is developed more than 4,000 feet below the surface.

1 Burgess, J. A., The halogen salts of silver and associated minerals at Tonopah, Nev.: Econ. Geology, vol. 6,1911 , pp. 13-21.

2 King, Clarence, The Comstock lode, in Hague, J. D., Mining industry: U. S. Geol. Expl. 40th Par., vol. 3, 1870, pp. 11-96. Church, J. A., The Comstock lode, New York, 1879. Becker, G. F., Geology of the Comstock lode and the Washoe district: Mon. U. S. Geol. Survey, vol. 3, 1882. Reid, J. A., The structure and genesis of the Comstock lode: Bull. Dept. Geology Univ. California, vol. 4, 1905, pp. 177-199. 


\section{King ${ }^{1}$ says:}

Quartz forms the only gangue in the Comstock lode. Those small masses of carbonate of lime which occur, intermingled with quartz, in the Gold Hill and Hale \& Norcross lower levels are rather to be considered an included mineral of accidental occurrence than as a true gangue. With the exception of small quantities of silver minerals contained in the clay sheets where they are placed in close contact with the bonanza, the whole silver tenor of the lode is contained in the bodies of quartz. The ore itself is composed of native gold, native silver, silver glance, stephanite, rich galena, occasional pyrargyrite, horn silver, and, with extreme rarity, sternbergite. Intimately associated with these occur iron and copper pyrites and zinc blende. Of these, pyrargyrite and horn silver are rarities; polybasite and sternbergite, in recognizable crystals, occupy a few scattered localities; stephanite, in defined crystallizations, has been found in nearly every bonanza, but the main body of the ore is a confused semicrystallized association of native gold and silver, vitreous silver ore, rich galena, copper and iron pyrites, and zinc blende.

In general the bonanza ore is pretty uniformly disseminated through the quartz. Large, solid accumulations are rarely found. The silver minerals ordinarily lie in masses about the size of a hen's egg. In the central portions of bonanzas there is usually a somewhat denser arrangement of ore. It is evident, from the manner in which the ore itself is broken and dislocated, that the dynamic action which powdered the quartz occurred after it was charged with ore.

Since the period of crushing additional charges of quartz and ore have been introduced into the fissure to a small extent. In a few places, as in the 800-foot level of the Yellow Jacket mine, broken fragments of quartz, themselves containing ore, have been recemented by sheets of stephanite which have penetrated the cracks, and over the stephanite a secondary growth of quartz crystals has taken place, and these quartz crystals themselves are again coated with a fine varnish of silica. ${ }^{2}$

Analyses of ore from the lower workings of the Savage and Kentuck mines (1869) gave zinc sulphide 1.75 and 0.13 per cent, respectively. Ores from "middle depths" of the California and Ophir mines gave 12.85 and 14.45 per cent of zinc.

Like King, Becker notes that there were clearly two periods of movement, one before the deposition of the primary ore and one after it. The later movement, mainly parallel to the lode, gave conditions for an active circulation of water after the primary deposition. According to Becker, "it is possible that the seams of rich ore in the great bonanza represent a deposition posterior to the final cessation of movement," and "it is also by no means impossible that some of the richer ores have been redeposited, forming at the expense of surrounding bodies of lower grade." As already remarked, analysis of the vadose water of the Comstock shows that it contains both gold 
and silver. It is noteworthy that this water contains much manganese, presumably as sulphate. Some associated placers were developed, but they are of very subordinate value compared with that of the lode. Oxidation extended downward to a depth of 500 feet. According to King," "a zone of manganese oxide occupies the entire length of the lode from the outcrop 200 feet down." The upper part of this manganiferous zone was not of high grade in general, especially in its uppermost portions. The longitudinal projections ${ }^{2}$ show that many of the stopes carried from below stop some distance below the surface.

Von Richthofen (quoted by Becker) says that "the proportion of gold to silver decreased during the early period of working the lode but is now (1865) on the increase again." Presumably silver at the very surface was.leached more rapidly than gold. The vadose waters, as shown by Reid, ${ }^{3}$ are rich in sulphate, and his analyses, as well as others, show the presence of chlorides in appreciable amounts. The conditions appear to have been favorable for the migration of both silver and gold in the upper levels, even in the comparatively short time that has elapsed since the primary ores were deposited. The bonanza ore below consisted largely of stephanite, polybasite, argentite, and other minerals.

I have no detailed descriptions of the character and position of the richest ores, but Eliot Lord ${ }^{4}$ states that the "Big Bonanza," an enormously rich ore body in the lode, extended below the fifteenth level. Possibly some of the richer ore bodies extended still deeper, but it is well known that rich ore was more abun in the upper than in the lower levels. The deposits in the upper levels yielded, according to Richthofen, from $\$ 70$ to $\$ 107$ a ton, whereas in later years the average value of the ore was not more than $\$ 37$ a ton.

It thus appears that the evidence of the Comstock lode, from the surface down, is favorable to the hypothesis that extensive solution and deposition of gold and silver have taken place.

The proportion of gold to silver was presumably higher near the surface and in the lower part of the lode than in the middle part. When Richthofen made his report he estimated that to the close of 1865 the lode had produced $\$ 15,250,000$ in gold and $\$ 32,750,000$ in silver (gold equals 47 per cent of the silver); whereas Becker reports the amount recovered from 1865 to 1881 as $\$ 87,121,988$ in gold and $\$ 105,548,157$ in silver (gold equals 83 per cent of the silver).

The relation of "horn silver" to the surface is different from that shown in "chloride mines." According to King, ${ }^{5}$ silver chloride is

1 King, Clarence, op. cit., p. 75.

2 Becker, G. F., op. cit., atlas sheets X-XII.

IReid, J. $\Lambda$., op. cit.

Lord, Eliot, Comstock mining and miners: Mon. U. S. Geol. Survey, vol. 4, 18\$3, p. 311.

- King, Clarence, op. cit., p. 82. 
accidental, although rare small crystals were found at the outcrop of the Gold Hill group and elsewhere.

\section{ST. EUGENE MINE, MOYIE, BRITISH COLUMBIA.}

The St. Eugene mine is in the mountainous country near Lake Moyie, British Columbia. This region is situated at a moderately high latitude and is therefore of particular interest, since the workable ore shows a relation to the present topography that appears to indicate appreciable secondary concentration. The deposit affords one of the best examples of sulphide enrichment that I have noted in Canada. The following data, from a report by S. J. Schofield, ${ }^{1}$ are supplied through the courtesy of Mr. R. W. Brock, director of the Geological Survey of Canada.

The claims operated by the principal company include two veins, which strike east and dip $70^{\circ} \mathrm{S}$. They are about 600 feet apart and the developments extend through a vertical range of 2,100 feet. The lower workings are over 100 feet below the level of Lake Moyie. The two main veins are connected by a series of important cross veins, most of which meet the main veins at acute angles. These cross fissures, the spaces between which are not uniform, are locally termed "avenues." Most of the ore bodies are in the fractured and folded area along and between the main veins, and in places large ore shoots occur near or at the places where the avenues meet the main veins. Very little displacement was observed along the main fissures, although the strata are slightly folded or bent near the fissures. The country rocks consist of argillaceous quartzites and purer heavybedded quartzites of the pre-Creston, the oldest known subdivision of the Purcell series, which here form the axis and eastern limb of an anticline. The ore bodies are associated with the massive purer quartzites of the pre-Creston formation. The ore consists of galena, both fine and coarse grained, associated in places with zinc blende. The gangue, which is small in amount, consists of garnet, anthophyllite (a variety of amphibole), and a little quartz, the last mineral being very prominent where the vein pinches in the argillaceous quartzites. Locally the wall rock in the immediate vicinity of the ore bodies shows strong metamorphism by the development of garnet and anthophyllite.

A vertical projection or stope sheet supplied by Mr. Brock shows workings along the hill for 4,900 feet. The slope of the hill is about $25^{\circ}$. Thirteen tunnels, one above another, are driven to the ore zone. Some of these tunnels are 2,000 to 3,000 feet long, but all the stopes appear to be within 1,500 feet of the surface, as measured on a level, or somewhat less than 800 feet from the nearest points

1 Schofield, \$. J., Reconnaissance in east Kootenay: Summ. Rept. Geol. Survey Canada for 1911, 1912, pp. 158-164. 
on the surface. The distance from the surface to which most of the ore shoots were followed is practically uniform. Below the level of the lake the workings did not extend so deep. At depth the fissures tighten, the ore becomes less concentrated, and zinc blende becomes relatively more abundant, so that the ore is no longer of commercial grade. At the junction of the "avenues" and main vein and nearer the surface were large bodies of clean shipping ore. Elsewhere the ore was concentrating ore. Mr. Brock informs me that a similar relationship between present surface and the ore bodies is noticeable at many points in the Slocan.

\section{COBALT, ONTARIO.}

Cobalt, ${ }^{1}$ in the Nipissing district, northern Ontario, is on the great ancient peneplain which extends over much of Ontario and the surrounding region. The country is hilly, but the relief is not great. The climate is cold and moderately moist. The recent glaciation is clearly evident, but drift is generally thin or absent.

The basement rocks are the Keewatin series, a complex of metamorphosed basic igneous rocks, usually known as greenstones, which includes also some rock of sedimentary origin. The eroded surface of the Keewatin is overlain by Huronian conglomerates, graywacke, and other metamorphosed sedimentary rocks. A quartz diabase sill some 500 feet thick was intruded into both Huronian and Keewatin rocks. This dips southward at an angle of about $17^{\circ}$.

The deposits are short, narrow fissure veins, very numerous and rich. They are found in the Huronian, in the diabase, and in the Keewatin, but the more productive deposits are in the Huronian near the diabase sill, or they were below the footwall of the sill before the sill was eroded. The deposits are probably genetically related to the diabase intrusive, and the fractures have been assumed to represent cooling cracks formed in connection with the intrusion of the diabase. Postmineral fracturing and faulting have taken place extensively.

The principal sulphides of earlier age include smaltite, cobaltite, chloanthite, and bismuth sulphide, with some arsenopyrite and tetrahedrite. Pyrite, galena, and sphalerite are present in the wall rock near the vein. The silver occurs as native metal, proustite, pyrargyrite, dyscrasite, and argentite. The gangue minerals include calcite and quartz.

The zone of oxidation is exceedingly shallow or altogether absent, but certain exceptionally rich superficial deposits, a few feet thick, are directly connected with the zone of weathering. This is called the "nugget horizon," and in it the smaltite and cobaltite have been

1 Miller, W. G., The cobalt-nickel arsenides and silver deposits of Temiskaming, 3d ed.: Rept. Ontario Bur. Mines, vol. 16, pt. 2, 1908. 
largely altered to secondary minerals or leached out altogether. In this zone "cobalt bloom" and "nickel bloom" are characteristic. minerals.

Extending downward 200 or 300 feet or more below the surface are rich silver minerals, largely in veinlets in earlier sulphides. The minerals of the veinlets include native silver, argentite, and calcite. The change from rich to low-grade ore is very abrupt, both in depth and on the strike. Van Hise ${ }^{1}$ and Emmons ${ }^{2}$ have attributed these richer silver ores to processes of sulphide enrichment, but Miller ${ }^{3}$ is inclined to the belief that this feature of the genesis has been too much emphasized.

\section{ROSSLAND, BRITISH COLUMBIA.}

Rossland, British Columbia, is in the Trail Creek district, a short distance north of the international boundary. The country is glaciated and the altitude of the principal deposits is about 3,400 feet above sea level. The rocks exposed ${ }^{4}$ include Carboniferous limestone, quartzites, and shales with interbedded tuffs, ash beds, and lavas. Above this series are volcanic agglomerates and lavas. Intruding these rocks are masses of monzonite, granodiorite, nepheline syenite, etc.

The principal deposits are fissure fillings and replacement veins, fractured zones, and impregnations. The most important lodes have steep dips. These lodes are intricately faulted and many of the faults follow or are followed by basic dikes. The deposits carry commercial amounts of copper and silver.

The gangue minerals are biotite, quartz, calcite, tourmaline, amphibole, chlorite, and garnet; the sulphides include pyrrhotite, chalcopyrite, pyrite, arsenopyrite, marcasite, gold, and other minerals.

In certain gold-bearing quartz veins the gold and chalcopyrite are intimately related and there is a notable concentration of gold near the surface.

The ore shoots in the cupriferous precious-metal lodes extend downward 50 to 500 feet. One shoot averaged 150 feet long and 56 feet thick and was worked downward 500 feet. There is very little oxidation above these deposits and no secondary chalcocite zone. The values of shipments decrease as greater depths are reached, but this decrease may be due to improvement of conditions which permits profitable extraction of lower-grade material.

\footnotetext{
1 Van Hise, C. R., The ore deposits of the Cobalt district, Ontario' Jour. Canadian Min. Inst., vol. 10, 1907, pp. 45-53.

2 Emmons, S. F., Cobalt district, Ontario, in Bain, H. F., and others, Types of ore deposits, San Francisco, 1911, pp. 140-156.

8 Miller, W. G., Notes on the Cobalt area: Eng. and Min. Jour., vol. 92, 1911, pp. 645-649.

'Brock, R. W., Preliminary report on the Rossland, B. C., mining district, Geol. Survey Canada, 1906.
} 


\section{CCEUR D'ALENE, IDAHO (LEAD-SILVER DEPOSITS).}

The geology and ore deposits of the Cœur d'Alene mining district, Idaho, are described by Ransome and Calkins.. ${ }^{1}$ The district is an area of pre-Cambrian quartzites and siliceous slates, which are intruded by large masses of monzonite and related rocks. Some contact metamorphism has taken place and certain of the ore bodies are of the garnet sulphide type, but the principal deposits are wide lead-silver lodes free from garnet.

The country is extensively faulted, but the lodes are not along the major faults. The ores were formed partly by filling open spaces, but largely by replacement along zones of fissuring or shearing. The deposits, which have a vertical range of 4,000 feet, were probably formed under several thousand feet of rock which has since been removed.

The ore minerals are galena, pyrite, chalcopyrite, sphalerite, and subordinate pyrrhotite, with some argentiferous tetrahedrite and stibnite. Siderite is the most abundant gangue mineral, with subordinate quartz and a little barite. The ores carry about 8 per cent lead and 4 ounces silver to the ton.

\section{Ransome ${ }^{2}$ says:}

Although the mineralogical character of the large lead-silver deposits exhibits great uniformity, some of the ore bodies are known to change their composition with increase of depth. No evidence has been found, however, that in any way connects the observed changes with the descent of solutions from the zone of oxidation. Such variations as occur are apparently original and not due to secondary enrichment from above.

In the process of 'oxidation cerusite develops from galena without any visible intermediate product. The change is not a direct replacement of the sulphur of carbonic anhydride, but the galena is irregularly corroded by the oxidizing solutions and cerusite crystals are deposited in the cavities thus formed. In other words, the lead itself is somewhat mobile during the change from sulphide to carbonate. The various minerals of the oxidized ores are still forming and make up soft earthy masses in which no sequence of crystallization is apparent. It is not known, for example, whether pyromorphite, like cerusite, forms directly from galena or whether it is derived from some oxysalt of lead.

The small quantity of sphalerite formerly in the ores which have undergone oxidation has left no recognizable trace of its presence.

\footnotetext{
I Ransome, F. L., and Calkins, F. C., The geology and ore deposits of the Cœur d'Alene district, Idaho: Prof. Paper U. S. Geol. Survey No. 62, 1908.

2 Idem, p. 112
} 


\section{INDEX.}

A. Page.

Acknowledgments to those aiding.......... 11

Adams, F. D., cited...................... 27 experiments of....................... 27

Adularia, occurrence of................... 152

Alabama. See Stone Hill.

Alaska, enrichment in ............... 162, 164, 166 oxidation in ..................... 17-18, 25

See also Prince William Sound; Kasaan Peninsula; Douglas Island; Berners Bay; Bonanza mine.

Albite, occurrence of

Allen, E. T., acknowledgments to........... 12 cited .......................... 59, 145, 149

Allen, E. T., and Crenshaw, J. L., cited . .... 140

Altitude, relation of, to enrichment......... 19

Aluminum, presence of, in mine waters..... 69

minerals of list of ................... 151 occurrence of .................... 151-155

Alunite, occurrence of ................. 154

Analysis, qualitative, analogy of, to enrichment processes................ 88-89

Anglesite, occurrence of................... 137

Ankerite, occurrence of ................ 147-148

Annie Laurie mine, Utah, geology of ....... 222 ores of ............................ 222

Antimony, presence of, in mine waters...... 68

Appalachians, geology of ................. 221 ores in..................... 39, 103, 221-222

Argentite, occurrence of . .............. 120-121

Aridity, relation of, to enrichment... 19, 36, 164, 165 relation of to oxidation.............. 165

Arizona, enrichment in.......... 34-35, 94, 164-165 mine waters from, analyses of.......... 70 ore deposition in .................... 21 ores of............... 33, 44-45, 98-105, 108, $109,112,142,146,153-154,157,159$ oxidation in..........10,32,33,34,36-40,42,45 See also Bisbee; Globe; Miami; Ray; Morenci; Jerome; Silver Bell.

Arsenic, presence of, in mine waters.

Arsenopyrite, occurrence of................ 150

Aspen, Colo., geology of . ............... 241 ores of............118, 123, 134,159, 160, 168, 241

A tacamite, occurrence of . ............... 100-101

Aurichalcite, occurrence of................. 142

Australia, enrichment in............... 167, 169-170 ores of.

Azurite, occurrence of. ................. 101-102 B.

Ball, S. H., Spurr, J. E., and Garrey, G. H., cited ............23, 149,232, 236-237

Bancroft, H., and Irving, J. D., cited....... 85, 92 , $109,122,124,139,156,160$
Bard, D. C., cited ....................... 98,176

Barite, occurrence of................... 159-160

Barlow, A. E., cited ....................... 18

Base-leveled regions, enrichment in......... 19-20 See also Erosion.

Bauxite, occurrence of................. 154-155

Becker, G. F., cited . .................... 247-248

Berners Bay, Alaska, geology of........... 219 ores of ............................ 166,219

Bingham, Utah, copper ores of............. 177

geology of ....................... 177 ores of... $33,36,38,39-40,97,99,100,103,104,105$, $109,111,113,124,134,135,148,159,177-179$

enrichment of . ......... 40,44,164, 165,177 oxidationat.................. 33, 36, 38, 177 silver and gold from ................. 177, 179

Bisbee, Ariz., copper ores of ............ 180-182 description of....................... 182 geology of . ..................... 179-180 mine waters from................... 182 ores of ............... 10,23,32,36,38, 39, 99, $100,101,102,104,105,108,112,153,180-182$

enrichment of....... 34-35,417,165,181-182 oxidation at.......... 10,32, 34, 36, 39, 181-182

Black Hills, geology of................... 219 mine waters from, analyses of.......... 70 ores of.......................... 219-220

enrichment of .................. 166,220

Blind lodes, enrichment of................. 24

Blow, A. A., cited.................. 139,142,244

Bodie, Cal., ores of ...................... 225 ores of, enrichment of............... 166,225

Bohemia district, Oreg., geology of ......... 228 ores of........................29,37,228 enrichment of .................... 228

Boleo, Lower California, Mex., geology at.... 203 ores of .......................... 203

Bonanza mine, Chitina belt, Alaska, geology

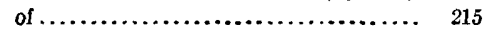
ores of............... 17-18,25,107,215-216

Bornite, occurrence of ................. 110-111

Boundary district, B. C., geology of ....... 209 ores of ..................... 162,163,209-210 oxidation in .......................... 209

Boutwell, J. M., cited....................... 38, $104,105,109,111,124,159,177-178$ Braden mines, Chile, deposits of .......... 18, $23,101,162,163,203-204$ geology of ........................ 203

Breckenridge, Colo., geology of........... 237 ores of ............... 139,142,148, 162,237-239 enrichment of ............... 168, 238-239 oxidation at............................ 238

Brewer, W. M., cited.................... 201 
Page.

British Columbia, enrichment in......... 18,25,

$162-163,167-169$

ores of....................... 108,110,112

See also Vancouver; Boundary; Hedley; Moyie; Rossland.

Brochantite, occurrence of................. 100

Brock, R. W., cited................... 209,249

Brokaw, A. D., experiments of ........ 126-127, 128

Buckley, E. R., cited.................. 150

Buehler, H. A., and Gottschalk, V. H., experiments of............ 49-51,76, 91

Bullfrog, Nev., ores of .................... 223 ores of, enrichment of............ 166,167,223

Burgess, J. A., cited.................... 116

Burro Mountains, N. Mex., geology of....... 193 ores of......................... 193-194

Butler, B. S., acknowledgments to........ 12 cited $. . \ldots \ldots \ldots \ldots \ldots \ldots \ldots .38,85, \mathbf{1 0 9 , 1 6 1 , 1 9 2}$ paper by, on San Francisco region..... 197-199

Butler, G. M., cited..................... 243

Butte, Mont., copper ores of................ 172 geology of ........................ 170-172 mine waters at.................... 173-176

analyses of .........60, $63,67,68,69,70,87$ ores of... $33,37,38,85,92,97,99,100,102,103,104$, $105-106,110,111,112,113,120-121$, $124,125,128,141,153,159,171-177$ enrichment of... 40,94, 164, 165, 168,174-175 oxidation at....................... 33,37,174 silver ores of. $172-173$

C.

Calamine, occurrence of ................ 142,155 Calcium, presence of, in mine waters........ 68-69 California, enrichment in ......... 162,164,166, 168 mine waters from, analyses of... $62,65,71,72,74$ ores of..... 106,109,111,112,120,124,130,142,159 sulphides in ...................... 18 See also Shasta County; Copperopolis; Mother Lode; Nevada City; Grass Valley; Ophir; Exposed Treasure mine; Bodie.

Calkins, F. C., and Ransome, F. L., cited.... 252 Campo Morado. See La Reforma mine.

Camsell, Charles, cited................... 220

Canada, oxidation in..................... 18,25

Cananea, Mex., geology of ................ 194 mine waters from, analyses of... 61, 64, 69,72,90 ores of............... 33,98,103,157,195-196 enrichment of ................ 44,164,196 oxidation at...................... 33,195-196

Carbonates, deposition of................ 161-162 occurrence of $. . . \ldots \ldots \ldots \ldots \ldots \ldots \ldots, 162$ presence of, in mine waters............67-68 solution of........................ 161

Catherinet, Jules, cited.................... $\quad 110$

Celestite, occurrence of . ................... 160

Cerargyrite, occurrence of ................ 119-120

Cerusite, occurrence of................... 138

Chalcanthite, occurrence of................ 100

Chalcedony, occurrence of ................. 156

Chalcocite, absence of ................... 162-163 deposition of, chemistry of............. 52 depth of.......................... 164,165 effect of, on depth of secondary zone..... 93-94

on gold enrichment................ 133-134
Page.

Chalcocite, occurrence of....... 25, 104-109, 164-165 origin of .................... 10,42,104,108 relation of, to glaciation.............. 162-164 to gold and silver................. 169

Chalcopyrite, occurrence of ............... 111-113 relation of, to occurrence of chalcocite.... 163,

164,165

Chemical equilibria, data on.............. 57-59

Chemistry of enrichment, experimental data relating to.................. 48-60

See also Mine waters; Oxidation; Solution; Precipitation; Enrichment; Sulphides; particular minerals; etc.

Chert, occurrence of..

Chile. See Braden mines.

Chitina belt, Alaska, geology of............. 215 ores of................ 17-18,25, 107, 215-216

Chlorine, presence of, in mine waters....... 66-67 Chrysocolla, occurrence of ............ 102-103, 155 Circulation. See Underground circulation.

Clark, Donald, cited.................... 167

Clarke, F. W., acknowledgments to........ 12

Clifton-Morenci district. See Morenci.

Climate, relation of, to enrichment....... 16-19,25

Cobalt, Ontario, geology of................ 250

ores of..................... 18, 119, 250-251

enrichment of ................... 25,251

oxidation at....................... 250

Cœur d'Alene, Idaho, geology of.......... 252 ores of. $105,109,119,122,134,135,136,147,159,252$ enrichment of .................. 165, 252

oxidation at........................ 252

See also Snowstorm lode.

Cold solutions, deposition by ............ 10, 13,16

Collins, A. L., cited.................... 54

Colorado, enrichment in... 22, 26, 34, 35, 166, 168, 169 mine waters from, analyses of.......... 62 , $63,67,69,70,71,72,73,74$ ores in.......................... 81-82, $98,102,109,118-125,128,129,130$, $137-139,141-142,148,153,157,159-162$

analyses of ..................... oxidation in ................. 35; 36, 37,81-82 underground water in ............... 29,30 See also Summit; San Juan: Cripple Creek;

Georgetown; Creede; Breckenridge; Rico; Lake City; Aspen; Leadville; Silverton; Custer County.

Comstock lode, Nev., geology of .......... 246 mine waters from, analyses of........ $68,69,70$ ores of........ 119, 121, 122, 123, 134, 169, 247-249 enrichment of . ...............22, 168,248 oxidation of ....................... 248 Contact-metamorphic deposits, deposition of ........................ 13,14 Cooke, H. C., cited.............. 115, 123, 158-159 Copper, leaching of, from gold copper ores... 97 minerals of, chemical relations of...... $95-113$

list of .......................... 95 occurrence of ......................... 97-113 solution of ............. 95-96 ores of, deposition of................... 13,16 deposits of......................162-165 enrichment of ...............9, 10,22-23 See also particular districts. 
Pagc.

Copper, precipitation of. $54-56,95,96$ presence of, in mine waters............. 70

Copper, native, occurrence and formation of. 98-100 Copper mines, waters of, analyses of........ 60-61 Copper-nickel ores, occurrence of ........... 14

Copperopolis, Cal., geology of............. 202 ores of ...................... 162,163, 202-203 enrichment of................. 202-203 oxidation at.......................... 202-203

Copper pitch, occurrence of................ 104

Cotunnite, occurrence of.................. 137

Covellite, occurrence of................... 109-110

Creede, Colo., geology of................. 239 mine waters from, analyses of. $63,67,71,72,73,141$ ores of .................. $36,119,120,128$,

$130,134,141,159,160,161,169,239-240$ enrichment of............ 26,166,168,240

Crenshaw, J. L., and Allen, E. T., cited..... 140

Cripple Creek, Colo., geology of............ 229 ores of........................ 37 , $81-83,102,124,154,156,159,160,229-232$

analyses of...................... 82 enrichment of............ 22, 166, 230-232 oxidation at........................ 37,231

Cuba, enrichment in..................... 164 See Santiago; Pinar del Rio.

Curtis, J. S., cited. $244-245$

D.

Deep-vein zone, deposits in $13,14-15$

De Kalb, Courtenay, cited. 224-225

Delamar mine, Nev., geology of

223

ores of............................. 223-224

oxidation at........................ 224

Diaspore, occurrence of ................. 154-155

Dickson, C. W., cited..................... 213

Diller, J. S., and Kay, G. F., cited........... 204

Dioptase, occurrence of ................... 103

Don, J. R., cited ....................... 126

Douglas, James, cited ................... 34

Douglas Island, Alaska, geology of......... 218 ores of..................... 17, 166, 218-219

Ducktown, Tenn., geology of.............. 205 mine waters from, analyses of........ $60-61$, $64,67,70,71,74,89-90,110,141,149$ ores of.................. $33,38,44,77,79$, $84,97,99-100,103,104,109,158,168,169,205-207$ analyses of....

$33,39,112-113,163,164,168,169,206-207$ oxidation at............ $33,37,38,39,44,78-79$ solution at.

77,84

E.

Earth's crust, openings in ............... 26-27

Edgemont, Nev., geology of. 218 ores of. 166,218

Electromotive potentials of sulphides, relative power of................. 50-51,76, 91

Ely, Nev., geology of................... 189 mine waters from, analyses of......... 71 ores of........... 108, 109, 134, 157, 159, 190-191 enrichment of............... 44,164, 191

Ely, vt., ores of ...................... 207-208 enrichment of...................... 164, 208
Embolite, occurrence of.

Emmens, $S$.

Emmons, S. F., acknowledgments to........ 11 cited ................ 54, 92, 153, 243-244, 251

Enargite, occurrence of .................. 113

Encampment district, Wyo., geology of..... 204 ores of.................. 38,39,109, 204-205 enrichment of ............... 39, 164, 205

Enrichment, chemistry of . ......... 10,11,48-162 chemistry of. See also Chemistry; Precipitation; Oxidation.

maximum depth of.................. 27 method of, analogy of, to laboratory methods...................... 88-89

theory of ......................... 9-11 applicability of, nonuniversality of.. $\quad 10$ Epigenetic deposits, classes of.............. 13 Erosion, rate of, relation of, to enrichment... 19, 21 Erosion, ice. See Glaciation.

Eureka, Nev., geology of ................. 244 ores of.......................... 244-245

Evaporation, precipitation due to.......... 43-44 Exposed Treasure mine (Mohave), Cal., geology at..................... 224 ores of........................ 120,224-225 enrichment of.............. 166, 168, 225 oxidation at........................ 224

F.

Ferguson, H. G., cited ................ 166-167 Ferric sulphate, reduction of............. 144 Famatinite, occurrence of.............. 113 Finch, J. W., cited. ........ 27, 29, 30-31, 43, 211, 231 Finlayson, A. M., cited............. 139,142,167 Fissures, relation of, to enrichment...... 20-21,92 Flowage, zone of....................... 26-27 Fracture, zone of ..................... 26i-27 zone of, enrichment in................ 27 Fuchs, Edmond, cited................. 203

\section{G.}

Galena, occurrence of................... 138 Gangue minerals, genesis of............. 150-151 list of........................... 151 See also Aluminum; Silica; Sulphur; Carbonates.

Garrey, G. H., Ball, S. H., and Spurr, J. E., cited............. 23, 149, 232, 236-237

Genth, F. A., cited.................... 85 Georgetown, Colo., geology at........ 232, 236-237 mine waters from, analyses of. .... $69,70,71,74$ ores of..... 119, 120,121,123, 149, 169, 232, 236-237 enrichment of........... 166, 168, 232, 237 oxidation at........................ 237 silver of.......................... 236-237 Georgia, ores of ....................... 128 Germany, mine waters from, analyses of.... 63 , $71,73,74$ Gibbsite, occurrence of............... 154-155 Glaciation, relation of, to enrichment..... 24-26, $162-164,166$ Globe, Ariz., copper ores of ............. 183-185 geology of ......................... 183 mine water in ..................... 184 ores of............ 21,101, 102,108, 112, 183-185 enrichment of .......40,45, 164, 165, 184-185 
Page.

Globe, oxidation at..................... 184

Gold,concentration of,in oxidized zone , 132-133,166 manganese and, relations of.......... 128-132, 166-167

migration of $166-169$

ores of, deposits of ................... 166-170 enrichment of .......... 9,132-133,166-170 relation of, to chalcocite....... 133-134 relation of, to glaciation......... 166

See also particular districts.

placers of, enrichment of............. 131 precipitation of ...... 95, 97-98, 128-129, 166-167 presence of, in mine waters............ 70 solution of....... 95,96-97, 125-127, 134,166-168 tellurides of ....................... 135

Gold Circle, Nev., geology of............... 223 ores of......................... 166, 223

Goldfield, Nev., geology of.............. 233 ores of.... 146,149,153,154,157,159,160,161, 233 enrichment of . ............. 22,166, 233

Gold placers, manganese, and relations of... 167

Gold mines, waters of, analysis of........ $62-63$

Goldschmidt, V. M., cited................. 106

Gordon, C. H., Lindgren, W., and Graton, L. C., cited............. 34,35,36,99

Goslarite, occurrence of..................... 141

Gossan, analyses of ..................... 78-79 poverty of........................... 31,33

Gossan lead, Va., geology of .............. 207 ores of .......................... 112,207 enrichment of ..................... 164

Gottschalk, V. H., and Buehler, H. A., experiments of............ 49-51,76,91

Grass Valley, Cal., geology of............ 216-217 mino waters from, analyses of.......... 68 ores of ............................ 166, 217

Graton, L. C., scknowledgments to......... 12 cited...... 22, 99, 104, 106, 111, 131, 142, 175, 176, $178,188,191-192,199,221-222,236$

Graton, L. C., Gordon, C. H., and Lindgren, W., cited............... 34, 35,36

Great Basin, enrichment in .............. 19,22

Gregory, J. W., cited..................... 153

Ground water, level of ................. 27-28

Grout, F. F., experiments of............ 49

Gypsum, occurrence of .................. 159

\section{H.}

Hanover district, N. Mex. See Santa Rita and Hanover districts.

Hedley, B. C., geology of . ............... 220 ores of ............................. 220

Hematite, occurrence of .................. 146

Hershey, O. H., cited .................... 219

Bickling, George, cited.................. 152

Hill, R. T., cited...................... 208

Hillebrand, W. F., analyses by............ 71 cited.................................. 74

Hills, R. C., cited................... 226-227

Hot solutions. See Thermal waters.

Hunter, W. H., acknowledgments to....... 12

Hydrogen sulphide, generation of.... . 87-88,91-92 precipitation of sulphides from....... $88-89,170$

Hydrozincite, occurrence of............... 142

Fynes, D. P., cited................... 46, 176
Page.

Idaho, enrichment in................... 165 ores of..... 105, 109, 119,122, 137, 139, 148, 149, 159

oxidation in ........................ 36

See also Coeur d'Alene; Snowstorm lode.

Information, sources of ................. 11-12

Ireland, mine waters from, analyses of...... 70

Iron, minerals of, chemical relations of..... 143-145

minerals of, list of ............... 143

occurrence of..................... 145-150

solution of........................ 143

presence of, in mine waters............ 69-70

sulphides of, oxidation of ....... 9, 32, 41-42, 144 precipitation of ................... 89,96

Irving, J. D., cited ....................

Irving, J. D., and Baneroft, H., cited....... 85, $92,109,122,124,139,156,160$

J.

Jaquet, J. B., cited........................ 169

Jarosite, occurrence of .................. 147, 161

Jasper, occurrence of........................ 156

Jerome, Ariz., geology of.................. 192

gold at........................... 193

mine waters from, analyses of........... 70

ores of ........................ 97, 192-193

enrichment of .................... 164, 193

oxidation at........................... 193

K.

Kaolin, occurrence of . . . . . . . . . . . . . 153-154

Kasaan Peninsula, Alaska, geology of........ 214 ores of..................17,162,163, 214-215

Kay, G. F., and Diller, J. S., cited ........... 204

Kemp, J. F., acknowledgments to......... 11 cited........... 27, 29, 101, 102, 108, 110,112, 210

King, Clarence, cited.............119, 123, 247-248

King, L. V., cited......................... 27

Kirk, C. T., cited....................... 153, 175

Knopi, Adolph, cited................... 219, 226

L.

Laboratory, analogy in, to sulphide enrichment....................... $88-8^{9}$

La Dicha, Mex., ores of................... 208

ores of, enrichment of................ 164, 208

Lake City, Colo., geology of .............. 240 ores of ...................... 92,109,121,

$122,124,134,139,156,160,169,240-241$

enrichment of ............... 85, 168,241

Laney, F. B., cited................. 46, 106-107 experiments of writer and.............. 64

Lang, S. S., cited......................... 194

La Reforma mine, Mexico, geology at..... 211 ores of ................. 18, 162,163, 165, 211

Latouche Island, Alaska, ores of.......... 17, 214

Lawson, A. C., cited .................... 157, 191 experiments of........................ 51

Lead, minerals of, list of................. 135 ores of, deposition of .................. 10 enrichment of . ................... 9,35 occurrence of..................... 136-139 oxidation of ....................... 82 solution of..................... 135-130

Lead, native, precipitation of .............. 136

Leadhillite, occurrence of ................ 137

Leadville, Colo., geology of................. 242 
Page.

Leadville, Colo., ores of............... 120,134,

$135,139,142,154,242-244$

enrichment of ......... 34, 166, 168, 243-244 oxidation at......................... 35

Leith, C. K., and Van Hise, C. R., cited..... 23

Lepsius, B., cited ....................... 64

Le Roy, O. E., cited...................... 209

Lewis, J. V., cited...................... 106

Limestone, oxidized copper ores in .......... 165

Limonite, occurrence of . ............... 145-146

Lincoln, F. C., cited..................... 214

Lindgren, Waldemar, acknowledgments to.. 12 cited............ 39, 40, 42, 55-56,77, 83, 85, 92 , $99,100,103-105,108,109,112,154$, $157,188-189,193-194,217,220,222$

Lindgren, W., and Ransome, F. L., cited .. 81-82,

Lindgren, W.; Graton, L. C., and Gordon,

C. H., cited . ........... 34, 35, 36, 99

Little Burro Mountains, N. Mex., geology of. 225 ores of....................... 166,225-226

Lodes, erosion of . ......................... 24,47

Lord, Eliot, cited . .................... 248

Lower California. See Boleo.

\section{M.}

McCaskey, H. D., acknowledgments to...... cited................................ 222

McCaughey, W. J., cited ................. 126

MacDonald, D. F., cited................. $\quad 228$

McLaughlin, R. P., cited................ 225

Maddren, A. G., and Moffit, F. H., cited.. 17-18, 216

Magmatic segregations, deposition of........ 13-14

Magnesium, presence of, in mine waters...... 69

Magnetite, occurrence of................. 140-147

Malachite, occurrence of ................ 101

Manganese, minerals of, list of ........... 130 minerals of, source of, in gold deposits. 130-131 oxides of, effect of, in gold precipitation. 128-129 presence of, in mine waters............. 69 sulphides of, occurrence of ............. 131

Manhattan, Nev., geology of.............. 222 ores of........................ 166, 167, 222

Marcasite, occurrence of................ 149-150

Maryland, ores of....................... $\quad 158$

Marysville, Mont., geology at............. 226 ores of ........................... 124,226 enrichment of............... 166, 169, 226

Melanterite, occurrence of................ 147 Metasomatic replacement, sequence of...... 84-86

Meteoric water, depth of penetration of...... 28-30 stagnation of......................... 30-31

Mexico, enrichment in................... 162-165 mine waters from, analyses of .......... 61

$64,69,72,90$ ores of ................. 23, 33,98, 103, 122, 157 oxidation in........................... 33 sulphides in.........................

See also Cananea; Nacozari; Lower California; La Dicha; San Jose; La Reforma mine; Velardeña.

Miami, Ariz., geology of ................... $\quad 185$ mine water in ...................... 184 ores of....................10,43,44, 185-186 enrichment of ............ 164, 165, 185-186 Mine waters, analyses of ................... $60-63$ analyses of, discussion of. $63-70$
Page.

Mine waters, composition of. ........... 60-74 changes in, with depth........ 70-73,89-90 precipitates from..................... $73-74$ Mining districts, review of................ 170-252 Missouri, ores of ...................... 138 Moffit, F. H., and Maddren, A. G., cited.. 17-18, 216 Mohave, Cal. See Exposed Treasure mine.

Montana, chalcocite in enrichment in ........... 33-34, 164-166, 168-169 erosion of lodes in .................. 47 mine waters from, analyses of... $60,63,64,69,70$ ores of............. 33, 99, 100,102-106,110-113 $119-125,128,130,137,139,141$; 145, 153, 159 oxidation in ................... 33, 37, 38, 40 See also Butte; Marysville; Philipsburg; Neihart.

Morenci, Ariz., geology of................ 187 ores of................. 33, 38-39, 42, $77,83-$ $84,85,92,98-99,100,102,103,104-105,108$, $109,112,142,146,153,154,157,159,187-189$ enrichment of ..........40,44,164,188-189 oxidation at.................. 33,36,38, 189

Mother Lode district, Cal., geology of........ 216 ores of.............................. 166,210

Mowbray, J. M., cited................... 18

Moyie, B. C., geology of.................. 249 ores of.................. 18, 168, 169, 249, 250

N.

Nacozari, Mex., geology of................ 196 ores of .................46,125, 162,163, 196 Nantokite, occurrence of................ 100-101 Neihart, Mont., geology of............... 234 ores of.......... 120, 121, 123-124, 139, 234-235

enrichment of. ................... 168,235 oxidation at........................ 234

Nevada, enrichment in ............. 22, 164, 166-169 oxidation in ....................... $36-37$ mine waters from, analyses of........... 60 , $62,63,65,69,70,71$ ores from................... $22,80-81$, $102,108,109,116,119-123,130,134$, $146,148,149,153,154,155,157,159,160$ analyses of....................... $79-80$ oxidation in ........................ 38 See also Ely, Nev.; Yerington; Silver Peak; Edgemont; Manhattan; Bullfrog; Gold Circle; Delamar mine; Goldfield; Eureka; Pioche; Tonopah; Comstock lode.

Nevada City, Cal., geology of............. 216-217 mine waters from, analyses of... 62, $71,72,74,87$ ores of $. \ldots \ldots \ldots \ldots \ldots \ldots \ldots \ldots \ldots .124,166,217$ New Hampshire, oxidation in.............. 25 New Jersey, ores of .................. 106,142 New Mexico, enrichment in........ 34, 35, 164-166 ores of................ 34-36,99, 103,120,142 oxidation in ........................ $34,35,36$ See also Santa Rita; Hanover; Burro Mountains; Little Burro Mountains.

New Zealand, enrichment in ............. 167

Nickel-copper ores, occurrence of........... 14

Nitrates, presence of, in mine waters.......... 68

Nodules, source of .................... 33-35

North Carolina. See Virgilina district.

Norway, ores of

$72293^{\circ}$-Bull. 529-13-17 
$\begin{array}{cc}0 . & \text { Page. } \\ \text { Oklahoma, ores of........................ } & 107\end{array}$

Ontario, enrichment of.................. 162-163

ores of............................... 14,119

oxidation in........................ 18, 25

See also Sudbury; Cobalt.

Ophir, Cal., geology of................... 217 ores of...................... 166, 217-218

Ore deposits. See Primary deposits; Secondary deposits.

Oregon, enrichment in. See also Queen of Bronze mine; Bohemia.

Organic matter, precipitation by........... 16

Ostwald, w., cited....................... 115

Oxidation, changes due to................ 78-83 chemistry of...... 9, 15, 16, 21,32-33,41-42,75-86 depth of........................ 36-37,165 relation of, to occurrence of chalco-

cite $\ldots \ldots \ldots \ldots \ldots \ldots \ldots \ldots \ldots \ldots, 163,165$

relation of, to ancient topography..... 10, 23-24 replacement due to, order of............ 84-86 See also Weathering.

Oxidized zone, characteristics of ............ 31-33 depth of.............................. 36-39 mine waters in ........................ 70 ores of, texture of...................... 44 relation of, to water table............... 37-38 segregation of metals in................ 33-35 solution and precipitation in............ 32-33 transition of, to secondary sulphide zone. 38-39

$P$.

Paige, Sidnoy, oited...

Paige, S., and Wright, C. W., cited........ 214-215

Paleotopography. 'See Topography, ancient.

Pearce, Richard, cited................... 126, 231

Pearceite, occurrence of................... 123-124

Pegmatite veins, deposition of ............... 13,14 deposits in ........................... 14

Renfield, S. L., cited..................... 124

Pennsylvania, ores of.................. 158

Penrose, A. F., jr., acknowledgments to .... 11 cited........................... 138, 830

Permcability, relation of, to occurrence of chalcocite..................... 163, 165 relation of, to enrichment........... 20-21, 170 See also Pore space.

Philippines, enrichment in............... 166-167

Philipsburg, Mont., geology of............. 233 ores of.......................... 112, $120,121,122,128,130,134,145,169,233-234$ enrichment of............4 47,166,168, 234

Phillips, J. A., cited...................... 169

Phosphates, presence of, in mine waters.... 68 Physical conditions, relation of, to enrichment.......................... 16-26 See also Climate; Relief; Altitude; Per- . meability; etc.

Pinar del Rio, Cuba, ores of................ 209 ores of; enrichment of................164,209

Pioche, Nev., geology of .................. 245 ores of....................... 168.169,245

Pisanite, occurrence of.................... 100

Pogue, J. E., thanks to .................. $\quad 59$

Polybasite, occurrence of.................. 123

Pore space, deposition in ................. 21 See also Permeability.
Page.

Potassium, presence of, in mine waters...... 68

Precipitation, chemlstry of ............. 9,15,

$16,21,32-33,43,46,48-60$

order of $57,84-86$

Primary deposits, age of, relation of, to enrichment...................... 22-23

alteration of ......................... 13

classification of ......................... 13

definition of ........................ 12

composition of, as affecting depth of secondary zone............... 92-94

genesis of ...........................

See also Cold solutions; Thermal waters; Syngenetic deposits; Epigenetio deposits.

Primary zone, ores of .....................

Prince of Wales Island. See Kasaan Peninsula.

Prince William Sound, Alaska, geology of.... 214 ores of ..................... 17, 162,163,214 enxichment of ................. 164,214

Proustite, occurrence of................. 122-123 Pseudomorphous replacement, occurrence of. $\quad 45$ Purington, C. W., cited.................... 228 Pyrargyrite, occurrence of .............. 121-122 Pyrite, effect of, on depth of secondary zone.. 93-94 occurrence of ........................ 148-149 oxidation of, chemistry of........... 48-52,56 relation of, to occurrence of chalcocite.... 163 Pyromorphite, occurrence of............ 136-137 Pyrrhotite, effect of, on depth of secondary zone...................... 93-94, 165

occurrence of ........................ 150 relation of, to occurrence of chalcocite.. 163-165 to gold and silver migration......... 168

\section{Q.}

Quartz, deposition of ................. 155-156 Queen of Bronze mine, Oreg., ores of....... 164, 204 oxidation in ......................... 204

\section{R.}

Rainfall, relation of, to enrichment.......... 18-19 Ransome, F. L., acknowledgments to....... 12 cited..... 23, 32, 35, 36, 37, 38, 43, 45, 100, 101, 105, $108,112,122,129,138,142,146,148,149$, $153,162,200-201,216,228-229,233,237-239$

paper by, on Bisbee district........... 179-182 on Globe and Miaml districts...... 183-186 on Jerome district................ 192-193 on Ray district................ 186-187 Ransome, F. L., and Calkins, F. C., cited.... 252 Ransome, F. L., and Lindgren W., cited....81-83, $229-231$

Ray, Ariz., copper ores of................ 186, 187 geology of......................... 186 ores of ............................ 43, 187 enrichment of................. 164, 165, 187 Raymond, R. W., cited .................. 227 Reduction, rate of ..................... 91-92 Reid, J. A., cited............... J.16, 134, 202, 248 Relief, relation of, to enrichment........... 19-20 Rhodesia, sulphides in.................. 18 Rhodochrosite, occurrence of............ 130-131, 162 Rhodonite, occurrence of ............... 130-131 Rickard, T. A., cited .................... 32, 126 
'Page.

Rico, Colo., geology of ores of.

Rösler, H., cited. $122,123,154,240$

Rossland, B. C., geology of ores of

Russell, Clarence, aid of.

\section{s.}

St. Eugene mine. See Moyie.

Sales, Reno, cited .................... 37, $38,77,105-106,110,111,113,174,175$

San Francisco district, Utah, geology of...... 197 ores of............... 85, 109, 143, 162, 197-199 enrichment of ................... 198-199

San Jose, Mex., geology of ................ 210 ores of ........................ 162,163,210

San Juan, Colo., geology of .............. 22S-229 ores of........................ 124, 128, 229 enrichment of ...................... 229

Sankowsky, N., aid of.

Santa Rita and Hanover districts, N. Mex. geology of

191

ores of...............44, 99, 103,191-192 enrichment of .................164,165, 192

Santiago, Cuba, ores of.................... 208 ores of, enrichment of............... 164, 208

Schofield, S. J., cited ..................... 249 Schuermann, E., experiments of....... 57-59, 84-85 Scope of paper............................. 10-11 Secondary deposits, definition of............ 12-13 Secondary sulphide zone, characteristics of.. 31 ,

depth of, dependence of, on composition of primary ore................ 92-94 dependence of, on fracturing........ 92, 94 marooning of, above water table........ 42 otes of, texture of....................... 44-46 position of.......................... 31,39-40 precipitation in....................... 42-44 relation of, to water table............. 39, 41-42 sulphur in, source of.................. $87-88$ transition to, from oxidized zone........ 3s-39

Sedimentary beds, deposits in........... 13

Seidell, Atherton, cited................... 143

Sericite, occurrence of ................. 152-153

Shasta County, Cal., geology of ........... 199 ores of......... 106, 111, 112,131,142,159,199-200 enrichment of .................... 164, 200

Shearer, H. K., aid of .

65

Siderite, occurrence of................. 147-148

Siebenthal, C. E., acknowledgments to..... 12

Silica, deposition of.................... 156-157 presence of, in mine waters............. 68 solution of ......................... 155

Silver, bromide of, solution of............... 115 chlorides of, movement of.............. 116 solution of................... 116, 134, 168

lodide of, solution of.................. 115 manganese and, relations of............. 168 migration of ...................... 168-170 minerals of, chemical relations of....... 115 list of........................... 114 occurrence of.................... 118-125 relations of...................... 114-118 ores of, deposits of .................. 168-170 enrichment of. See also particular districts.

\section{Page.}

Silver, precipitation of . $54,55,95,97-98,116-118,168$ presence of, in mine waters............ 70 pyrrhotite and, relations of .......... 168-169 solution of............... 95,97, 114-116, 134 sulphate of, solution of................. 115 sulphides of, enrichment of............ 40 precipitation of ................... 85

tellurides of......................... 135

Silver, native, occurrence of ............. 118-119 Silver Bell, Ariz., geology of................ 197 ores of.......................... 197

Silver mines, waters of, analyses of ........ 62-63 Silver Peak, Nev., geology of............. 218 ores of........................... 166, 218

Simpson, J. F., cited................... 106,175

Smith, Alexander, cited.................. 115

Smithsonite, occurrence of............... 141-142 Snowstorm mine, Idaho, ores of .... 36, 105, I65, 202 oxidation at........................ 202 Sodium, presence of, in mine waters........ 68 Solution, chemistry of ................. 9 , $15,16,21,32-33,43,46,48-60,75-86$ factors in......................... $75-76$ order of........................ 57, 59,76-78 rate of............................. $75-77$

in oxidizing environment........... 76-78

in reducing environment........... 83-84 zone of. See Oxidized zone.

Sommerlad, H., experiments of............ 123

Sonora, Mex. Sce Nacozari.

South Carolina, enrichment in............. 167 South Dakota. See Black Hills.

Spain, chemistry of leaching in............ 53-54 enrichment in ....................... 164 mine waters from, analyses of.......... 70 ores of.............. 97,111,112, 125, 134, 142 Spencer, A. C., acknowledgments to........ 12 cited....................... 52, 108, 218, 219 paper by, on Ely, Nev., district....... 189-191 Sphalerite. See Zinc, sulphide of.

Spurr, J. E., cited ...................... 79-81, $118,158,218,241-242,245-240$

Spurr, J. E., Garrey, G. H., and Ball, S. H., cited.............. 23, 149, 232, 236-237

Stagnant water, depth to.................. 30-31

Stephanite, occurrence of .................. 123

Stevens, H. T., cited . ............ 198, 203, 209-210

Stokes, H. N., cited ..... 78, 90, 108-109, 126, 133, 158

Stone Hill, Ala., ores of.................. 207 ores of, enrichment of ..............164; 207

Structure, relation of, to enrichment.......... 24

Sudbury, Ont., geology of................. 212 ores of............. 10,17,18,162,163,212-213 enrichment of.................... 212

Sullivan, E. C., experiments of ......... 54-56, 100

Sulphates, deposition of ................... 9 formation of ......................... 65-66 migration downward of................ 9,32 occurrence of ...................... 158-161 presence of, in mine waters...........65-66 solubility of ................... 53, 157-158

Sulphate solutions, acidity of............ 65 acidity of, decrease of, with depth.. 70-73,89-90 deposition by ......................... 9,13 oxidation of ........................... 90-91 Sulphide deposits, progressive alterations of, with depth................... 31 zone of................................ 31-47 
Sulphides, enrichment of. See Enrichment. enrichment of, zone of. See Secondary sulphide zone.

oxidation of

during .......... 78-83

factors in ........................ 75-76

reduction of, relative rate of ........... 91-92

relative electromotive force of...... 50-51,76,91

relative precipitation of................ 57-59

relative solubility of .............57,59,76-78

replacement of, by secondary sulphides, order of...................... 57,84-86

solution of, factors in .................. 75-76

rate of ......................... $75-77$

in oxidizing environment....... 76-78

in reducing environment....... 83-84

See also Secondary sulphides.

Sulphide zone. See Secundary sulphide zone.

Sulphur, occurrence of .................. 158-161

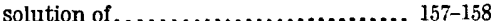

Sulphur, native, occurrence of............. 158-159

Sulphuric acid, formation of ................ $65-66$ presence of, in mine waters............. 65-66

Summit, Colo., geology at................ 226-227

ores of............................ 227

enrichment in ..................... 227

Syngenetic deposits, classes of ............. 13

$\mathbf{T}$.

Tarr, W. A., cited....................... 107

Ternperature, relation of, to enrichroents.... 16-18

Tenuantite, occurrence of .............. 113, 125

Tennessee. See Ducktown.

Teuorite, occurrence of ................... 104

Tetrahedrite, occurrence of ........... 113, 124-125

Thermal waters, deposition by .............. 13,15

deposits of .......................... 15-16

Tiutic, Jtah, geology of .................... 235 ores of.......................... 32,36,37, $77,113,121,156,157,159,161,165,235-236$

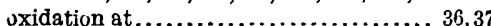

T'olrnan, C. F., cited..................... 189

Tonopah, Nev., mine waters from, analyses of $. . . \ldots \ldots \ldots \ldots \ldots \ldots \ldots \ldots \ldots \ldots \ldots, 63$

ores of ................. 36, 79-81, 116, 119, $120,121,122,123,148,159,169,245-246$

analyses of....

enrichment of

oxidation at....................... $36-37,246$

Topography, ancient, relation of, to oxidation 10 ,

Tovio W. 23-24, 37, 42-43, 182

Treadwell. See Douglas Island.

Tutton, A. E. H., cited . ......

Tyson, J. W. cited........................ 208

U.

Underground circulation, relation of, to enrichment...................... 26-31

Utah, enrichment in ..................... 162, 165 mine waters from, analyses of .......... 73 ores of . 33,38 , $99,103-105,109,111,113,121,124$ $134,138,143,148,156,158,159,161$ oxidation in .................. 33,36,37,38-40 See also Bingham; San Francisco; Annie Laurie mine; Tintic.

v.

Vadose water, definition of depth of
Vadose zone, oxidation in

Page.

sulphides marooned in ................... 36, 42

Vancouver, B. C., geology of............. 201 ores of.............................. 201

Van Hise, C. R., acknowledgments to...... 11 cited.............................. 26, 251

Van Hise, C. R., and Leith, C. K., cited..... 23

Veinlets, secondary, occurrence of.......... 45-46

Velardeffa, Mex., geology at............. 211-212 ores of.................... 18,23,162,163,212

Vermont. See Ely, Vt.

Virgilina district, Va.-N. C., ores of......... 46, 106-107,112, 164 ores of, anrichment of.................46,87 Virginia. See Virgilina district; Gossan lead.

Vogt, J. H. L., cited.... 26, 115, 118-119, 139, 158, 169 experiments of ....................... 52

W.

Water, underground. See Vadose water; Meteoric water; Ground water; Stagnant water.

Water table, level of....................... 27-28 ores oxidized beneath.................... 37-38

Watson, T. L., cited.................... 207

Weathering, effect of, on sulphide ores...... 9 See also Oxidation.

Weed, W. H., acknowledgments to......... 11 cited.......... 43, 92, 109, 111, 113,123-124, 139, $174-176,203,207,208,226,235$

Weigel, 0., acknowledgments to............ 12 . experiments of.................. 57-59, 84

Wells, R. C., acknowledgments to........... 12 cited ............................ $12 \mathrm{~s}$ experiments of . $58,59-60,83-84,88,91-92,109,136$

Willemite, occurrence of............... 142, 155

Winchell, $\mathrm{B}$. V., acknowledgments to....... 12 cited.......................... 108,113,175 experiments of ................. 48,51-52 Winslow, Arthur, occurrence of............ 150

Wright, C. W., and Paige, S., cited........ 214-215

Wurtz, Henry, cited....................... 125

Wurtzite, occurrence of.................... 143

Wyoming, enrichment in................... 164 ores of........................... 38, 39, 103 See also Encampment district.

\section{$\mathrm{Y}$.}

Yates, W. S., cited .........................

Yeatman, Pope, cited.................... 23

Yerington, Nev., geology of.............. 250 ores of........................ 109,200-201 enrichment of.................. 201 Z.

Zinc, minerals of, list of ................. minerals of, occurrence of............ 141-143 solution of $\ldots \ldots \ldots \ldots \ldots \ldots \ldots \ldots . .140-141$ ores of, deposition of................... 16 enrichment of..................... 9,35 oxidation of ...................... $41-42,82$ presence of, in mine waters............ 70 sulphide of, effect of, on depth of second-

ary zone...................... 93-94 occurrence of .............. 142-143, 163-165 precipitation of ................. 89, 141 relation of, to gold and silver....... 169-170 solution of..................... 140-141 Zinc blende. See Zinc, sulphide of. 醇 